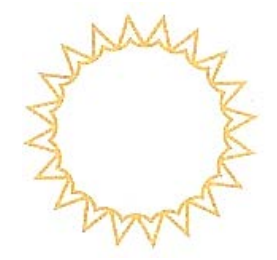

UNIVERSIDADE DE SÃO PAULO

FACULDADE DE ARQUITETURA E URBANISMO

SILVIA BIGONI

EFICIÊNCIA DOS CONJUNTOS ÓTICOS DE ALUMÍNIO

ESPECULAR DE ALTO DESEMPENHO ENERGÉTICO

São Paulo

2013 
AUTORIZO A REPRODUÇÃO E DIVULGAÇÃO TOTAL OU PARCIAL DESTE TRABALHO, POR QUALQUER MEIO CONVENCIONAL OU ELETRÔNICO, PARA FINS DE ESTUDO E PESQUISA, DESDE QUE CITADA A FONTE.

E-mail da autora: silviabigoni@uol.com.br

Bigoni, Silvia

O594e Eficiência dos conjuntos óticos de alumínio especular de alto desempenho energético / Silvia Bigoni. -- São Paulo, 2013.

252 p. : il.

Dissertação (Mestrado - Área de Concentração: Tecnologia da Arquitetura) - FAUUSP.

Orientador: Marcelo de Andrade Roméro

1.Iluminação 2.Luminárias 3.Alumínio 4.Tratamento de superfícies

5.Fotometria 6.Ensaios ópticos I.Título

CDU 628.9 
SILVIA BIGONI

\section{EFICIÊNCIA DOS CONJUNTOS ÓTICOS DE ALUMÍNIO ESPECULAR DE ALTO DESEMPENHO ENERGÉTICO}

Dissertação apresentada à Faculdade de Arquitetura e Urbanismo da Universidade de São Paulo para obtenção do Título de Mestre.

Área de concentração: Tecnologia da Arquitetura

Orientador: Prof. Dr. Marcelo de Andrade Roméro

São Paulo

2013 
Ao meu pai. 
Agradeço primeiramente ao meu orientador, Prof. Dr. Marcelo de Andrade Roméro, pela preciosa orientação, compreensão e dedicação.

Ao amigo e grande incentivador, Me. Eng. Alan Nascimento, meu profundo agradecimento pela amizade, excepcional paciência, dedicação incansável, as preciosas contribuições nos últimos meses e, principalmente, pelas horas destinadas às medições em laboratório.

Ao Me. Arqt. Nelson Solano Vianna, pelo seu apoio antes mesmo do meu ingresso no mestrado, pela dedicação ativa e, sobretudo, pelas valiosas contribuições.

Ao Dr. Arqt. Isac Roizenblat, por todos os anos de ensinamentos, críticas, considerações, discussões e diretrizes seguras que sempre me ajudaram na vida profissional e acadêmica.

Agradeço a todos aqueles que, de alguma forma, permitiram que esta obra fosse concluída, entre eles Ruy Barbosa Soares, Silvia Helena Alves de Oliveira, Corina Bianco, Cristiane Sato, Altimar Cypriano e Luiz Felipe Xavier.

Agradeço, especialmente, ao Sr. Carlos Carolino, pelo apoio e doação das luminárias e por possibilitar as medições no Laboratório de Fotometria da sua empresa, Carolino Indústria e Comércio Ltda.

Meus agradecimentos, em particular atenção, para o Srs. Wilson e Wiliam Sallouti, da empresa FASA Fibra Ótica; ao Sr. Ricardo Belucci Lucchi e Dante Lucchi, da Lucchi Ltda.; e Sr. Francisco Antônio da Cunha, síndico responsável pelo Condomínio Porto de Ibiúna, pelos espaços cedidos para a execução dos ensaios de campo.

Agradeço a minha família pelo eterno apoio. 


\section{RESSUMO}

Este trabalho tem por finalidade indicar uma metodologia de avaliação das perdas progressivas de iluminâncias, de intensidades luminosas e de rendimentos que ocorrem nos conjuntos óticos com distintos tratamentos de superfícies dos alumínios, utilizados na produção de luminárias comerciais com lâmpadas fluorescentes tubulares.

Alguns critérios foram relacionados como imprescindíveis para a obtenção de resultados representativos, sendo o parâmetro geográfico o primeiro deles. Para isso, foram indicadas três instalações onde o critério de escolha eram os agentes atmosféricos externos, de elevada, média ou menor poluição ambiental. O segundo foi a escolha de "luminárias de ensaios", com conjuntos óticos em alumínios especulares de diferentes características e propriedades de reflexão. O último critério foi o temporal, com medições fotométricas praticadas em laboratório e em campo. Foram adotadas para análise e comparação as medições fotométricas de três conjuntos óticos de referência (refletor e aleta), bem como luminárias de ensaio de campo em dois períodos para análise da depreciação dos conjuntos óticos, que totalizaram uma média de $2.700 \mathrm{~h}$.

Como resultado desta análise, foram feitas considerações que demonstram que padrões de alumínio de menor ou maior rendimento, com capacidade reflexiva entre $75 \%$ e $95 \%$, apresentam perdas luminosas consideráveis, e que podem causar divergência entre o projetado pelos profissionais de iluminação e o executado.

Palavras-chave: Conjunto ótico. Tratamento de superfície. Alumínio. Luminárias. Depreciação. 


\section{ABSTRACT}

This work aims to specify a methodology for evaluating the progressive loss of illuminance, luminous intensity and performance, which occur in the optical assemblies of commercial fixtures with fluorescent lamps, whose aluminium received different types of surface treatment.

In order to obtain representative results, some criteria were listed as essential, being the geographic parameter the first one. For this, we chose three facilities using as a criterion of choice the external atmospheric agents of high, medium or low environmental pollution. The second was the choice of "test fixtures" with optical assemblies made of specular aluminium with different reflection characteristics and properties. The last criterion was the time lapse, with photometric measurements practiced in laboratory and in the field. For analysis and comparison, we took photometric measurements of three optical sets used as reference (reflector and fin) and field test fixtures in two different periods for depreciation analysis of their optical assemblies, which reached an average of 2700 hours.

As a result, considerations have been made demonstrating that Aluminium patterns of higher or lower performance with reflective capacity between $75 \%$ and $95 \%$, show considerable light loss, and that this can cause divergence between what is the projected by the lighting professionals and what is effectively executed.

Keywords: Optical Assembly. Surface Treatment. Aluminium. Luminaires. Depreciation. 


\section{Agradecimentos}

Resumo

Abstract

Lista de abreviaturas e siglas

Lista de grandezas e unidades SI

Lista de símbolos

Lista de Figuras

Lista de tabelas e fluxogramas

Glossário

1 INTRODUÇÃO 36

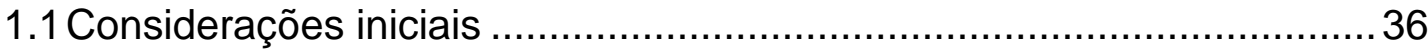

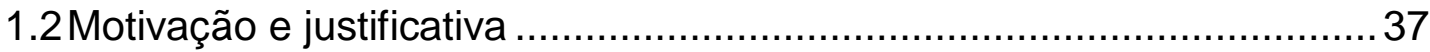

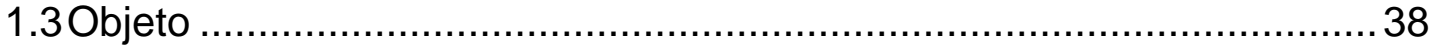

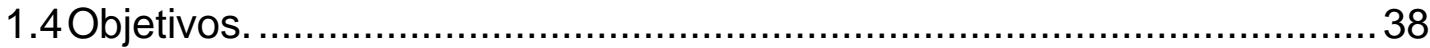

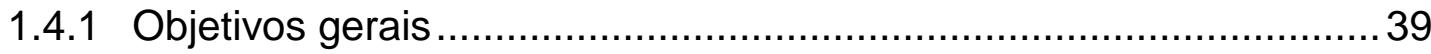

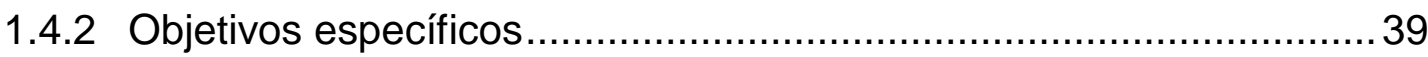

2 MÉTODOS E TÉCNICAS .................................................................. 40

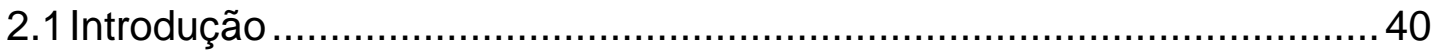

2.2 Levantamento dos dados secundários ......................................... 41

2.3Escolha dos sistemas óticos ................................................... 42

2.3.1 Características dos conjuntos óticos de ensaios ...........................43 43

2.3.2 Características das luminárias de ensaios ................................... 45

2.3.2.1 Quantidades de luminárias de ensaios.................................... 46

2.3.3 Características das lâmpadas fluorescentes tubulares de ensaios ... 47

2.3.4 Características dos reatores eletrônicos de ensaios ......................4 47

2.4Escolha da localização onde foram realizados os ensaios ................... 47

2.5Escolha dos períodos para a realização dos ensaios em campo e laboratório

2.5.1 Ensaios em laboratório ......................................................... 49

2.5.1.1 Etapas de ensaios ..................................................... 49

2.5.1.2 Equipamentos utilizados no laboratório para as medições fotométricas. 
2.5.2 Instalações de campo 56

2.5.3 Condições dos ensaios e procedimentos em campo e laboratório.... 62

2.5.4 Método para determinação dos rendimentos dos sistemas óticos ....64 64

3 DADOS SECUNDÁRIOS - ASPECTOS NORMATIVOS, DE CERTIFICAÇÕES E REGULAMENTAÇÕES ...................................66

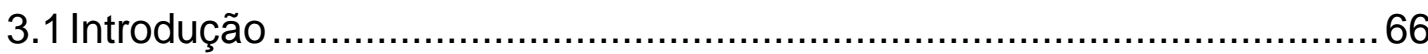

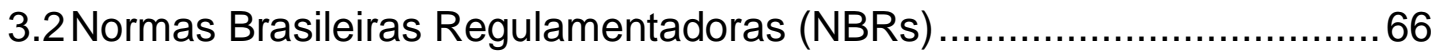

3.2.1 ABNT NBR 5461:1991 - Iluminação (terminologia) ......................... 66

3.2.2 ABNT NBR 5413:1992 - Iluminância de interiores..........................67

3.2.3 ABNT NBR 5382:1985 - Verificação da iluminância de interiores Métodos de ensaios

3.2.4 ABNT NBR ISO 8995-1:2013 - Iluminação de ambiente de trabalho (futura)

3.2.5 ABNT NBR IEC 60598-1:2010 - Luminárias - Parte 1 - Requisitos gerais e ensaios 69

3.2.6 ABNT NBR IEC 60598-2-1:2012 - Luminárias - Parte 2 -

Requisitos particulares - Capítulo 1:Luminárias fixas para uso em iluminação geral 69

3.3Certificações de edifícios sustentáveis .......................................... 70

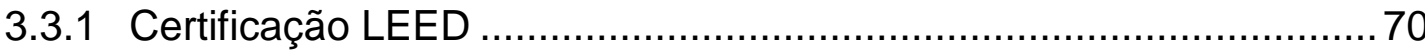

3.3.2 Certificação AQUA............................................................ 71

3.4Regulamentações .................................................................. 72

3.4.1 Procel Edifica: Plano de ação para eficiência energética em Edificações

3.4.1.1 Regulamento Técnico da Qualidade do Nível de Eficiência

Energética de Edifícios Comerciais, de Serviços e

Públicos (RTQ-C)

3.4.1.2 Regulamento de Avaliação da Conformidade do Nível de Eficiência Energética de Edifícios Comerciais, de Serviços e Públicos $(R A C-C)$............................................................... 75

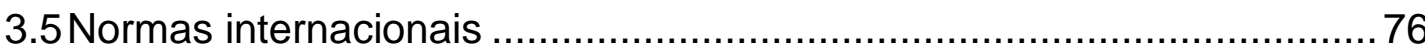

4 DADOS SECUNDÁRIOS - AS TECNOLOGIAS APLICADAS NOS SISTEMAS DE ILUMINAÇÃO COMERCIAL 78

4.1 Introdução 78 
4.2 Luminárias para uso comercial e de serviços ................................... 80

4.2.1 Classificação das luminárias ................................................. 89

4.2.2 A concepção da luminária funcional ........................................... 93

4.2.3 Execução do projeto do refletor .......................................... 96

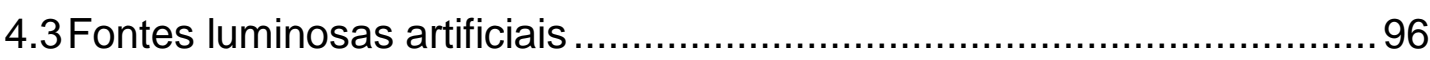

4.3.1 Lâmpadas de filamento incandescente e halógena....................... 97

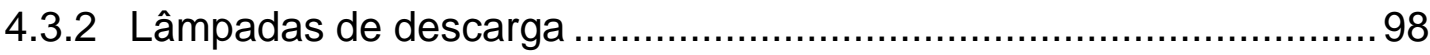

4.3.2.1 Lâmpadas de descarga de baixa pressão - fluorescentes

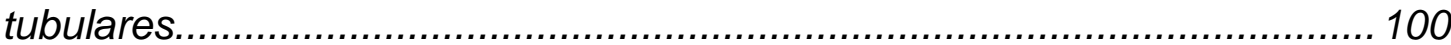

4.3.2.1.1 Lâmpada fluorescente tubular T5 HE..................................... 102

4.3.2.2 Lâmpadas de descarga de alta pressão ...................................... 105

4.3.3 Tecnologia LED ............................................................ 108

4.3.4 Eficiência energética das lâmpadas .......................................... 109

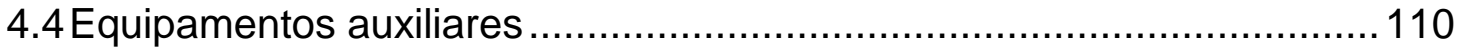

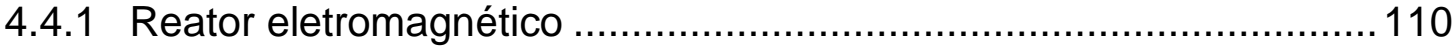

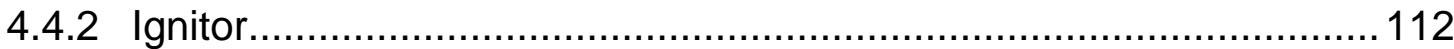

4.4.3 Reatores eletrônicos........................................................... 112

5 DADOS SECUNDÁRIOS - CRITÉRIOS QUANTITATIVOS DE DESEMPENHO DA ILUMINAÇÃO E DOS SISTEMAS EM USO .......... 117

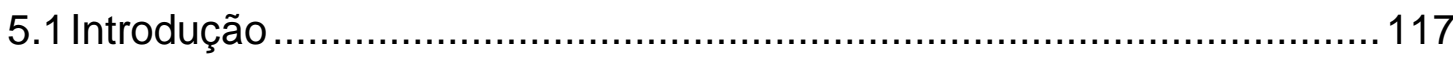

5.2 Características fotométricas.................................................. 117

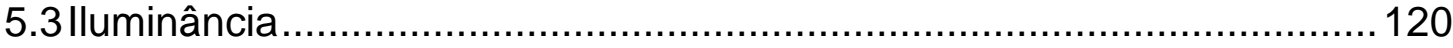

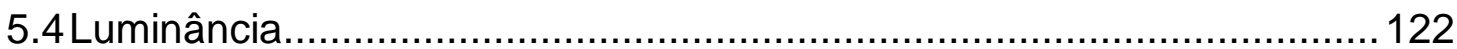

5.5Curva de distribuição de intensidade luminosa.................................. 123

5.5.1 Classificação das luminárias de acordo com o direcionamento do fluxo luminoso............................................................ 124

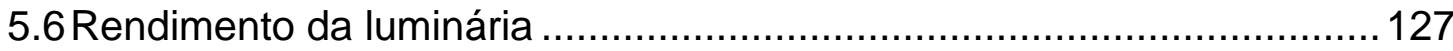

5.7 Fator de Utilização (FU) .............................................................. 129

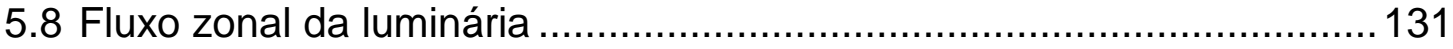

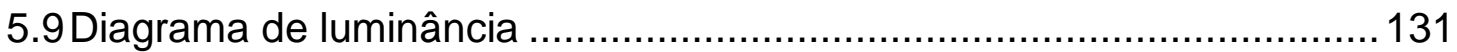

5.10 Índice de ofuscamento unificado (UGR) .................................. 132

5.11 Fator de manutenção......................................................... 134

5.11.1 Fatores de manutenção de referência........................................ 138

5.11.2 Fator de manutenção do fluxo luminoso $L L M F \ldots \ldots \ldots \ldots \ldots \ldots \ldots \ldots \ldots \ldots . . . \ldots 139$ 
5.11.3 Fator de sobrevivência da lâmpada LSF ................................. 139

5.11.4 Fator de manutenção da luminária LMF ...................................... 140

5.11.5 Fator de manutenção da sala RMF ........................................... 140

\section{DADOS SECUNDÁRIOS - OS PROCESSOS INDUSTRIAIS EMPREGADOS} NOS SISTEMAS DE ILUMINAÇÃO ................................................. 141

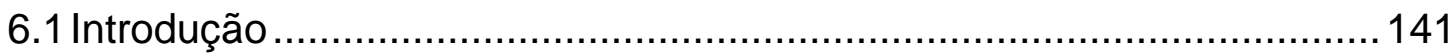

6.2 Processo de obtenção do alumínio ................................................ 143

6.3 Propriedades físicas e químicas ....................................................... 151

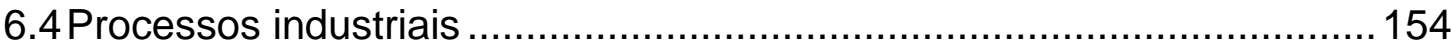

6.4.1 Sistemas de classificação do alumínio e suas ligas........................... 156

6.5Tratamento de superfície no alumínio.......................................... 164

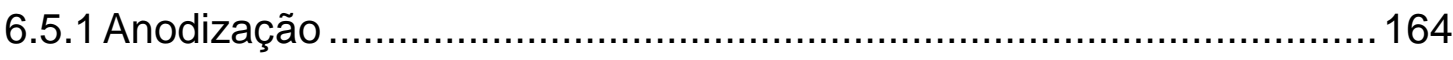

6.5.2 Processo da anodização...................................................... 167

6.5.2.1 Etapas básicas do processo de anodização................................ 174

6.5.3 Tipos de anodização por tratamento químico .................................. 181

6.5.4 Anodização em processo contínuo ................................................ 182

6.5.4.1 Etapas do processo de anodização continua ............................... 183

6.5.4.2 Principais vantagens no processo de pré-anodização.................... 186

6.5.5 Anodização por processo de deposição física do vapor (PVD) .......... 187

6.6 Características dos alumínios objeto de estudo................................ 190

6.7 Mercado nacional de alumínio utilizado na indústria de iluminação....... 192

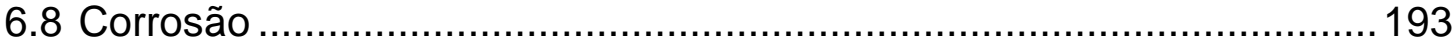

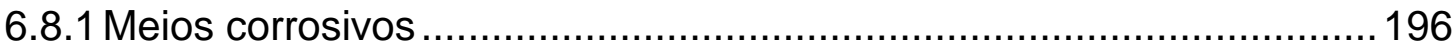

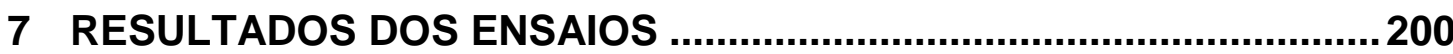

7.1 Procedimentos utilizados para os ensaios ...................................... 200

7.2Resultados dos ensaios dos conjuntos óticos de referência - R A1,

R B1 e R C1 ........................................................................... 202

7.2.1 Ensaio do conjunto ótico de referência - R A1 ..............................202

7.2.2 Ensaio do conjunto ótico de referência - R B1 ............................... 203

7.2.3 Ensaio do conjunto ótico de referência - R C1 ................................ 204

7.3 Resultados dos ensaios das luminárias de campo - Instalação 1

FASA Fibra Ótica, Peruíbe, SP - FA A1, FA B1 e FA C1 .................... 205

7.3.1Ensaio da luminária de campo - FA A1 - (1.512 h) ........................ 205

7.3.2 Ensaio da luminária de campo - FA A1 - (2.640 h) ....................... 206 
7.3.3Ensaio da luminária de campo - FA B1 - (1.512 h) ....................... 207

7.3.4Ensaio da luminária de campo - FA B1 - (2.640 h) ........................ 208

7.3.5Ensaio da luminária de campo - FA C1 - (1.512 h) ........................ 209

7.3.6 Ensaio da luminária de campo - FA C1 - $(2.640$ h) ....................... 210

7.4Resultados dos ensaios das luminárias de campo - Instalação 2

LUCCHI Ltda., Cotia, SP - LU A1, LU B1 e LU C1.......................... 211

7.4.1Ensaio da luminária de campo - LU A1 - (1.576 h)....................... 211

7.4.2 Ensaio da luminária de campo - LU A1 - (2.720 h) ....................... 212

7.4.3Ensaio da luminária de campo - LU B1 - (1.576 h) ....................... 213

7.4.4Ensaio da luminária de campo - LU B1 - (2.720 h)...................... 214

7.4.5Ensaio da luminária de campo - LU C1 - (1.576 h) ....................... 215

7.4.6Ensaio da luminária de campo - LU C1 - (2.720 h) ........................216

7.5Resultados dos ensaios das luminárias de campo - Instalação 3 - Condomínio

PORTO de IBIÚNA, Ibiúna, SP - PO A1, PO B1, PO C1 ....................217

7.5.1 Ensaio da luminária de campo - PO A1 - (1.648 h) ....................... 217

7.5.2 Ensaio da luminária de campo - PO A1 - (2.856 h) ....................... 218

7.5.3Ensaio da luminária de campo - PO B1 - (1.648 h) ......................... 219

7.5.4 Ensaio da luminária de campo - PO B1 - $(2.856$ h) ....................... 220

7.5.5 Ensaio da luminária de campo - PO C1 - (1.648 h) ........................ 221

7.5.6 Ensaio da luminária de campo - PO C1 - $(2.856$ h) ....................... 222

8 APRESENTAÇÃO E ANÁLISE DOS RESULTADOS............................ 223

9 CONSIDERAÇÕES FINAIS, CONCLUSÕES E CONTRIBUIÇÕES DA DISSERTAÇÃO E SUGESTÃO PARA FUTUROS TRABALHOS........ 227

9.1 Considerações finais................................................................ 227

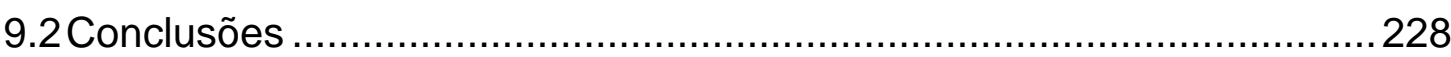

9.3 Contribuições da dissertação .................................................. 229

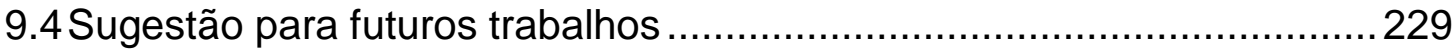

BIBLIOGRAFIA REFERENCIADA ...................................................... 231

BIBLIOGRAFIA CONSULTADA .......................................................... 236

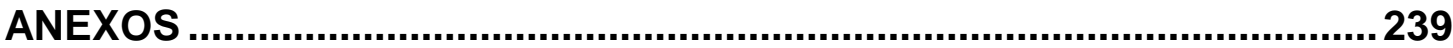

Anexo I - Registros fotográficos das etapas dos ensaios em laboratório .... 241

Anexo II - Contribuição de ensaios já executados................................. 244

Anexo III - Dados dos produtos empregados nos ensaios ...................... 247 


\section{பISTA DE ADRREVIATURAS E SIGLAS}

ABAL

Associação Brasileira de Alumínio

ABILUX

Associação Brasileira da Indústria de Iluminação

ABNT

Associação Brasileira de Normas Técnicas

ALCOA

Alcoa Alumínio S/A

AMN

Associação Mercosul de Normalização

ANSI

American National Standards Institute

ASHRAE

AQUA

American Society of Heating, Refrigerating and Air-Conditioning Engineers

BIES

Alta Qualidade Ambiental

CBA

British Illuminating Engineering Society

CEN

Companhia Brasileira de Alumínio

CENELEC

European Committee for Standardization

CIE

European Committee for Electrotechnical Standardization

COPANT

Commission Internationale de l'Éclairage

DIN

Comissão Panamericana de Normas Técnicas

DIN

German Institute for Standardization

ELETROBRÁS Centrais Elétricas Brasileiras

ENCE Etiqueta Nacional de Conservação de Energia

HQE Haute Qualité Environnemetale

IAI International Aluminium Institut

IEC International Electrotechnical Commission

IES Illuminating Engineering Society

IESNA Illuminating Engineering Society of North America

INMETRO Instituto Nacional de Metrologia, Qualidade e Tecnologia

IPT

Instituto de Pesquisas Tecnológicas 
Mineração Rio do Norte S/A

NBR

Norma Brasileira Regulamentadora

PROCEL Programa Nacional de Conservação de Energia Elétrica

RTQ-C Regulamento Técnico da Qualidade do Nível de Eficiência Energética de Edifícios Comerciais, de Serviços e Públicos

RAC-C

Regulamento de Avaliação da Conformidade do Nível de Eficiência Energética de Edifícios Comerciais, de Serviços e Públicos

SGE

Sistema de Gestão do Empreendimento

SI

Sistema Internacional de Unidades

SISCOMEX

Sistema Integrado de Comércio Exterior

QAE

Qualidade Ambiental do Edificio

USGBC

U.S. Green Building Council 


\section{LISTA DE GRANDEZAS E UNIDADES SD}

\section{Grandezas}

Área

Comprimento

Concentração

Consumo por unidade de tempo

Densidade de potência de iluminação relativa

Massa

Massa

Massa especifica

Potência, fluxo de energia

Pressão

Quantidade de calor

Quantidade de matéria

Resistência elétrica

Temperatura Celsius

Tempo

Tensão elétrica

Trabalho, energia, quantidade de calor

Volume

\section{Unidade}

metro quadrado

metro

mol por metro cúbico

quilowatt-hora

watt por metro quadrado

p/a100lx

quilograma

tonelada

quilograma por metro cúbico $\mathrm{kg} / \mathrm{m}^{3}$

watt

megapascais

caloria

mol

ohm

grau Celsius

hora

volt

joule

metro cúbico

megawatt-hora

gigawatt-hora

\section{Símbolo}

$\mathrm{m}^{2}$

m

$\mathrm{mol} / \mathrm{m}^{3}$

KWh

$\mathrm{W} / \mathrm{m}^{2} / 100 \mathrm{~lx}$

$\mathrm{kg}$

t

W

$\mathrm{MPa}$

cal

mol

$\Omega$

${ }^{\circ} \mathrm{C}$

h

V

J

$\mathrm{m}^{3}$

MWh

GWh 


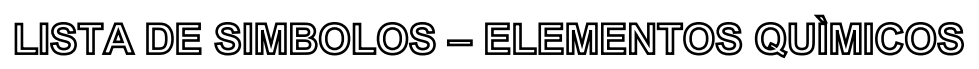

\begin{tabular}{|c|c|}
\hline Nome & Símbolo \\
\hline Alumínio & Al \\
\hline Ácido Bórico & H3BO3 \\
\hline Alumina (Óxido de Alumínio) & $\mathrm{Al}_{2} \mathrm{O}_{3}$ \\
\hline Aluminato de sódio & $\mathrm{Na}_{2} \mathrm{Al}_{2} \mathrm{O}$ \\
\hline Bicarbonato & $\mathrm{HCO}$ \\
\hline Brometo & $\mathrm{Br}$ \\
\hline Carbono & C \\
\hline Cálcio & $\mathrm{Ca}$ \\
\hline Cloreto & $\mathrm{Cl}$ \\
\hline Cobre & $\mathrm{Cu}$ \\
\hline Criolita & $\mathrm{Na}_{3} \mathrm{AlFe}_{6}$ \\
\hline Cromo & $\mathrm{Cr}$ \\
\hline Estanho & Sn \\
\hline Estrôncio & $\mathrm{Sr}$ \\
\hline Ferro & $\mathrm{Fe}$ \\
\hline Fluoreto & $\mathbf{F}$ \\
\hline Lítio & Li \\
\hline Magnésio & Mn \\
\hline Manganês & Mg \\
\hline Nefelina & $\mathrm{NaAlSiO}_{4}$ \\
\hline Óxido de silício & $\mathrm{SiO}_{2}$ \\
\hline Óxido de titânio & $\mathrm{TiO}_{2}$ \\
\hline Óxido férrico & $\mathrm{Fe}_{2} \mathrm{O}_{3}$ \\
\hline Oxigênio & 0 \\
\hline Silício & Si \\
\hline Sódio & $\mathrm{Na}$ \\
\hline
\end{tabular}


Zinco

Zn 


\section{LISTA DE FIGURAS}

Figura 1 Fluxograma geral da pesquisa

Figura 2 Luminária composta por corpo e um conjunto ótico (refletor e aleta)

Figura 3 Modelo do conjunto ótico adotado para os ensaios

Figura 4 Luminária modelo CS-656, adotada como padrão de ensaio, catálogo do fabricante Carolino Indústria e Comércio Ltda.

Figura 5 Conjuntos óticos de referências R A1, R B1 e R C1 50

Figuras 6 e Goniofotômetro manual

7

Figuras 8 e Goniofotômetro manual, limbos graduados 9

Figuras 10 e Luxímetro MINOLTA posicionado a 6 metros do 11 goniofotômetro

55

Figura 12 Luxímetro MINOLTA, modelo T-10 55

Figura 13 Estabilizador de tensão linear, modelo TRA-BB/13

Figura 14 Localização da instalação 1 -FASA Fibra Ótica, Peruíbe, SP

Figura 15 Fluxograma da instalação 1- FASA Fibra Ótica, Peruíbe, SP

Figura 16 Identificação das luminárias de ensaios - instalação 1FASA Fibra Ótica, Peruíbe, SP - Etapas 2 e 3

Figuras 17 e Instalações das luminárias de ensaios FA A1, FA B1 e 18 FA C1, na área de montagem da indústria FASA Fibra Ótica, Peruíbe, SP 58

Figura 19 Localização da instalação 2 - LUCCHI Ltda, Cotia, SP 58

Figura 20 Fluxograma da instalação 2 - LUCCHI Ltda, Cotia, SP 59

Figura 21 Identificação das luminárias de ensaios - instalação 2 LUCCHI Ltda, Cotia, SP- Etapas 2 e 3

Figuras 22 e Instalação das luminárias de ensaios LU A1, LU B1, LU 23

C1 na área de armazenagem no centro de distribuição da LUCCHI Ltda, Cotia, SP 
Figura 24 Localização da instalação 3 do Condomínio PORTO de IBIÚNA, Ibiúna, SP

Figura 25 Fluxograma da instalação 3- Condomínio PORTO de IBIÚNA, Ibiúna, SP

Figura 26 Identificação das luminárias de ensaios - instalação 3 Condomínio PORTO de IBIÚNA, Ibiúna, SP- Etapas 2 e 3

Figuras 27, Instalação das luminárias de ensaios PO A1 (sala de 28 e 29 reunião), PO B1 (sala da administração) PO C1 (sala da gerência e recepção) do Condomínio PORTO de IBIÚNA, Ibiúna, SP

Figura 30 Modelo da Etiqueta Nacional de Conservação de Energia- ENCE, neste caso apresentando níveis de eficiência $A$

Figura 31 Área de atuação das empresas do setor de iluminação 78

Figura 32 Percentual por área de atuação do setor de iluminação 79

Figura 33 Principais produtos fabricados pelo setor de iluminação 79

Figura 34 Refletores especulares para lâmpadas fluorescentes tubulares

Figura 35 Acabamentos de superfícies de alumínio: acabamento especular (espelhado), semi-especular, fosco (matt) e acetinado (texturizado)

Figura 36 Reflexão Especular

Figura 37

Reflexão Difusa.

Figura 38 Reflexão Total = Reflexão Especular + Reflexão Difusa 84

Figura 39 Exemplos a e b de componentes mecânicos das 86 luminárias para lâmpadas fluorescentes tubulares lineares.

Figura 40 Exemplos modelos $\mathbf{d}$, e e f de luminárias tipo downlight (luz direta)

Figura 41 Sala de conferência, aplicação de luminária tipo downlight, com lâmpadas fluorescentes tubulares T5 $14 \mathrm{~W} / 840$ 
Figura 42 Exemplos a, b, c e d de luminárias de sobrepor fluorescentes tubulares lineares

Figura 43 Escritório corporativo com aplicação de luminária de sobrepor para lâmpada fluorescente tubular

Figura 44 Família de lâmpadas de descarga 99

Figura 45 Funcionamento da lâmpada fluorescente tubular 100

Figura 46 Combinação de halofosfato e trifósforo no revestimento das lâmpadas fluorescentes

Figura 47 Representação da reflexão da luz com a redução do diâmetro do tubo das lâmpadas fluorescentes tubulares ( T12-36 mm, T10-33,3 mm, T8-26 mm, T5-16mm)

Figura 48 Processo de emissão de luz de um LED

Figura 49 Indicação das eficiências luminosas em função do tipo de lâmpada

Figura 50 Representação gráfica das potências envolvidas em um circuito não resistivo

Figura $51 \quad$ Esfera intregradora ou Esfera de Ulbricht

Figura 52 Superfície fotométrica

Figura 53 Curva fotométrica horizontal

Figura $54 \quad$ Curva fotométrica vertical

Figura 55 lluminância está relacionada com a densidade de fluxo

Figura 56 Curva de distribuição de intensidade luminosa conforme planos

Figura 57 Curva polar de uma luminária fluorescente para lâmpada fluorescente tubular T8, modelo DBL 591 2X32W, INDELPA

Figura 58 Comparativo de sistema com ou sem sistema ótico.

Figura 59 Fator de utilização pelo método dos lúmens CIE de uma luminária para lâmpada fluorescente tubular T8 modelo DBL 591 2x32W, INDELPA

Figura 60 Fator de utilização pelo método das cavidades zonais 
de uma luminária para lâmpada fluorescente tubular T8 modelo DBL 591 2x32W, INDELPA

Figura 61 Ângulos críticos de visualização

Figura 62 Diagrama de luminâncias $L\left(\mathrm{~cd} / \mathrm{m}^{2}\right)$

Figura 63 Diagrama definindo os índices de ofuscamento UGR $\quad 134$

Figura $64 \quad$ Iluminâncias durante o período de uso de um sistema 135 de iluminação

Figura $65 \quad$ Elementos metálicos não ferrosos na crosta terrestre 141

Figura $66 \quad$ Esquema de produção integrada para obtenção do 143 alumínio

Figura $67 \quad$ Bauxita

Figura 68 Fases da produção de alumina - da entrada do minério à saída do produto

Figura 69 Salas de cubas

Figura 70 Célula de redução

Figura 71 Vazamento de liga de alumínio

Figura 72 Classificação do alumínio e suas ligas

Figura 73 Processo de laminação

Figura 74 Processo de laminação a frio

Figura 75 Processo de laminação a quente

Figura 76 Processo esquemático de laminação contínua

Figura 77 Processo eletrolítico ou eletroquímico

Figura 78 Corte esquemático de um feixe de células hexagonais

Figura 79 Película anódica no principio de formação em um eletrólito, com ação dissolvente sobre a película

Figura $80 \quad$ Camada anódica

Figura 81 Fluxograma de identificação dos estágios de anodização, conforme aplicação 
Figura 82 Fluxograma dos estágios básicos no processo de anodização

Figura 83 Processo de coloração anódica

Figura 84 Superfícies e acabamentos por processo de anodização contínua

Figura 85 Processo de anodição da linha contínua: 1.250 mm.

Fábrica da ALMECO, San Giuliano Milanese (MI), Itália

Figura 86 Etapas do rebobinador, anodização e desbobinador da linha continua 1.250mm. Fábrica da ALMECO, San Giuliano Milanese (MI), Itália

Figura 87 Linha de corte de bobinas da linha continua 1.250mm. Fábrica da ALMECO, San Giuliano Milanese (MI), Itália

Figura 88 Redução da rugosidade da superfície (rugosidade e 186 dissolução de micro-picos durante laminagem) por polarização anódica em um banho de ácido concentrado

Figura 89 Bobinas de alumínio natural e bonina de alumínio préanodizado

Figura 90 Influência da liga e revestimento na reflectância final do material

Figura 91 Camadas reflexivas e protetoras do alumínio pelo 188 sistema PVD (Physical Vapour Deposition), desde o substrato do alumínio

Figura 92 Linha de produção pelo sistema PVD (Physical Vapour Deposition). Fabrica ALMECO, Bemburg, Alemanha

Figuras 93 e Vista das cabines de controle e estágio de entrada onde o processo de deposição a vácuo é iniciado

Figuras 95 e Processo magnetron- sputtering 96

Figuras 97 e Processo de anodização PVD (Physical Vapour 98 Deposition)

Figura 99 Elevação das reflexões das superfícies óticas, conforme processo de anodização 
Figura 100 Reflexão total (\%) de distintos materiais metálicos

Figura 101 Redução na intensidade da luz com múltiplas reflexões

Figura 102 Estimativa do uso do alumínio no mercado nacional (t)

Figura 103 Ciclo dos metais

Figura 104 Distância entre goniofotômetro e a fotocélula do luxímetro

Figuras 105 Registro fotográfico dos preparativos para os ensaios dos conjuntos óticos de referência - R A1, R B1 e R C1

Figuras 107 Registro fotográfico dos preparativos para os ensaios

Figuras 109 Registro fotográfico dos preparativos para os ensaios dos conjuntos óticos de referência - R A1, R B1 e R C1

Figuras 111, Identificação das luminárias de campo - FA B1, LU C1 112 e 113 e PO A1

Figuras Registro fotográfico dos conjuntos óticos de referência 114,115 e R A1, R B1 e R C1

116

Figuras Registro fotográfico das luminárias de campo - FA A1,

117,118 e Fa B1 e FA C1, após período de 1.512 horas de

119 funcionamento

Figuras Registro fotográfico das luminárias de campo - FA A1,

120,121 e Fa B1 e FA C1, após período de 2.640 horas de

122

funcionamento

Figura 123 Ensaio de determinação dos índices de refletância Alumínio Nacional - IPT

Figura 124 Ensaio de determinação dos índices de refletância Alumínio 100/030/B - IPT

Figura 125 Dados técnicos da lâmpada fluorescente tubular T5 HE FH 14/28W - Osram do Brasil

Figura 126 Dados técnicos do reator eletrônico QUICKTRONIC 
QTP 5 14-35W/230-240V - Osram do Brasil

Figura 127 Esquema de ligação do reator eletrônico

QUICKTRONIC QTP 5 14-35W/230-240V - Osram do Brasil

Figura 128

Dados técnicos alumínio ALCOA

250

Figura 129 Dados técnicos alumínio 100/030/B - 100/040/B 251 ALMECO

Figura 130 Dados técnicos alumínio VEGA 95100 - ALMECO 


\section{LISTA DE TAABELAS E FÖRRMULASS}

Tabela 1 Propriedades dos alumínios empregados nos conjuntos óticos

Tabela 2 Propriedades reflexivas dos alumínios empregados nos conjuntos ótico.

Tabela 3 Quantidade de luminárias utilizadas para os ensaios de campo e laboratório

Tabela 4 Período das medições em laboratório da Etapa 1

Tabela 5 Período das medições em laboratório da Etapa 2

Tabela 6 Período das medições em laboratório da Etapa 3.

Tabela 7 Identificação das luminárias de ensaios- Instalação 1 FASA Fibra Ótica, Peruíbe, SP

Tabela 8 Identificação das luminárias de ensaios- Instalação 2 LUCCHI Ltda, Cotia, SP

Tabela 9 Identificação das luminárias de ensaios- Instalação 3 Condomínio PORTO de IBIÚNA, Ibiúna, SP

Tabela 10 Registro das datas das instalações, retiradas e períodos de funcionamento dos sistemas

Tabela 11 Constantes zonais para intervalos de $10^{\circ}$

Tabela 12 Planilha padrão para tabulação das ilumininâncias , intensidades luminosas e rendimento no plano transversal longitudinal

Tabela 13 Matérias-primas na fabricação de luminárias

Tabela 14 Classificação adotada de iridescência dos alumínios

Tabela 15 Grau de proteção indicado pelo primeiro numeral característico contra ingresso de corpos sólidos externos

Tabela 16 Grau de proteção indicado pelo primeiro numeral característico contra ingresso de água

Tabela 17 Descarga elétrica e pela pressão interior da lâmpada

Tabela 18 Temperatura de cor correlata (Tcp)

Tabela 19 Características das lâmpadas fluorescentes tubulares T5 HE (High Efficiency)

Tabela 20 Características das lâmpadas fluorescentes tubulares T5 
$\mathrm{HO}$ (High Output)

Tabela 21 Classificação da CIE de luminárias para iluminação geral, 125 de acordo com fluxo luminoso

Tabela 22 Exemplos de luminâncias que definem os índices de ofuscamento UGR

Tabela 23 Exemplos de fatores de manutenção para sistemas de iluminação de interiores com lâmpadas fluorescentes tubulares

Tabela 24 Fatores de manutenção para sistemas de iluminação de 138 interiores com lâmpadas fluorescentes, conforme condições da instalação

Tabela 25 Parâmetros do consumo da alumina 149

Tabela 26 Insumos para aprodução de alumínio primário

Tabela 27 Propriedades do alumínio

Tabela 28 Propriedades físicas típicas do alumínio/aço/cobre.

Tabela 29 Impurezas e seus efeitos

Tabela 30 Formulação típica de uma solução de polimento eletrolítico.

Tabela 31 Composto ideal para a redução da formação de gases tóxicos no processo de polimento

Tabela 32 Concentrações típicas de impureza na atmosfera.

Tabela 33 Tabulação do conjunto ótico de referência - R A1

Tabela 34 Tabulação do conjunto ótico de referência - R B1

Tabela 35 Tabulação do conjunto ótico de referência - R C1

Tabela 36 Tabulação da luminária de ensaio - Instalação 1 - FASA 205 Fibra Ótica, Peruíbe, SP - FA A1 Período de seis meses (1.512 h)

Tabela 37 Tabulação da luminária de ensaio -Instalação 1 - FASA 206 Fibra Ótica, Peruíbe, SP - FA A1 Período de doze meses (2.640 h)

Tabela 38 Tabulação da luminária de ensaio -Instalação 1 - FASA Fibra Ótica, Peruíbe, SP - FA B1 Período de seis meses (1.512 h)

Tabela 39 Tabulação da luminária de ensaio -Instalação 1 - FASA 
Fibra Ótica, Peruíbe, SP - FA B1

Período de doze meses (2.640 h)

Tabela 40 Tabulação da luminária de ensaio -Instalação 1 - FASA 209

Fibra Ótica, Peruíbe, SP - FA C1

Período de seis meses (1.512 h)

Tabela 41 Tabulação da luminária de ensaio -Instalação 1 - FASA

Fibra Ótica, Peruíbe, SP - FA C1

Período de doze meses (2.640 h)

Tabela 42 Tabulação da luminária de ensaio -Instalação 2 - LUCCHI

Ltda, Cotia, SP - LU A1

Período de seis meses (1.576 h)

Tabela 43 Tabulação da luminária de ensaio - Instalação 2 - LUCCHI

Ltda, Cotia, SP - LU A1

Período de doze meses (2.720 h)

Tabela 44 Tabulação da luminária de ensaio -Instalação 2 - LUCCHI

Ltda, Cotia, SP - LU B1

Período de seis meses (1.576 h)

Tabela 45 Tabulação da luminária de ensaio - Instalação 2 - LUCCHI

Ltda, Cotia, SP - LU B1

Período de doze meses $(2.720 \mathrm{~h})$

Tabela 46 Tabulação da luminária de ensaio -Instalação 2 - LUCCHI

Ltda, Cotia, SP - LU C1

Período de seis meses (1.576 h)

Tabela 47 Tabulação da luminária de ensaio - Instalação 2 - LUCCHI

Ltda, Cotia, SP - LU C1

Período de doze meses ( $2.720 \mathrm{~h}$ )

Tabela 48 Tabulação da luminária de ensaio -Instalação 3 -

Condomínio PORTO de IBIÚNA, Ibiúna, SP - PO A1

Período de seis meses (1.648 h)

Tabela 49 Tabulação da luminária de ensaio - Instalação 3 -

Condomínio PORTO de IBIÚNA, Ibiúna, SP - PO A1

Período de doze meses (2.856 h)

Tabela 50 Tabulação da luminária de ensaio -Instalação 3 - 
Condomínio PORTO de IBIÚNA, Ibiúna, SP- PO B1

Período de seis meses (1.648 h)

Tabela 51 Tabulação da luminária de ensaio - Instalação 3 -

Condomínio PORTO de IBIÚNA, Ibiúna, SP - PO B1

Período de doze meses (2.856 h)

Tabela 52 Tabulação da luminária de ensaio - Instalação 3 -

Condomínio PORTO de IBIÚNA, Ibiúna, SP- PO C1

Período de seis meses (1.648 h)

Tabela 53 Tabulação da luminária de ensaio - Instalação 3 -

Condomínio Porto de IBIÚNA, Ibiúna, SP - PO C1

Período de doze meses (2.856 h)

Tabela 54 Redução percentual dos rendimentos das luminárias de

campo em relação aos conjuntos óticos de referência

Tabela 55 Desvios das medições das luminárias de campo - PO A1, PO B1 e PO C1

Tabela 56 Diferença entre os rendimentos dos modelos de referência 226 ensaiados

Tabela 57 Ensaios de câmara úmida executados no IPT

Fórmula 1 Fluxo luminoso

Fórmula 2 Fluxo luminoso

Fórmula 3 Iluminância

Fórmula 4 Iluminância média

Fórmula 5 Luminância

Fórmula 6 Luminância para difusores perfeitos

Fórmula 7 Coeficiente de reflexão

Fórmula 8 índice de ofuscamento unificado

Fórmula 9 Fator de manutenção 


\section{Abrilhantamento}

Ácido

Álcalis

Alumínio

Anodização

Anodo

Aparência de cor

Bauxita

Camada de óxido

anódico

Característica nominal (de uma lâmpada)

Catodo
Produção de superfícies brilhantes por polimento químico ou eletrolítico da superfície do metal.

Ácido é toda a substância que se ioniza em presença de água e se origina, como um dos íons, o cátion $\mathrm{H}+$.

É qualquer substância que libera única e exclusivamente o ânion $\mathrm{OH}^{-}$em solução aquosa.

O alumínio é um elemento químico de símbolo Al de número atômico 13 (13 prótons e 13 elétrons), com massa atômica 27 u. Na temperatura ambiente é sólido, sendo o elemento metálico mais abundante da crosta terrestre.

O alumínio é um metal que aparenta ser inerte à ação da atmosfera, devido a uma fina camada de óxido que se forma naturalmente sobre sua superfície. O metal alumínio é um elemento que reage com ácidos e álcalis com evolução de hidrogênio.

É um processo eletrolítico que promove a formação de uma camada controlada e uniforme de óxido na superfície do alumínio.

Em eletrólise, o eletrodo no qual os íons negativos são descarregados e os íons positivos formados, podendo ocorrer outras reações de oxidação.

Expressão geral para a impressão de cor recebida pela observação de uma fonte de luz.

Óxido de alumínio hidratado. É o minério mais importante do alumínio

Filme protetor formado na superfície do alumínio e suas ligas pelo processo de anodização.

Conjunto de valores nominais e das condições de funcionamento que servem para caracterizar e denominar uma lâmpada.

Em eletrólise, o eletrodo no qual os íons positivos são descarregados e os íons negativos formados, podendo ocorrer outras reações de oxidação. 
Certificação

\section{Conjunto ótico}

Cor

Corpo da luminária

Coloração

Curva de

isointensidade

Curva de

isoluminância

Diagrama de isointensidade
É um conjunto de atividades desenvolvidas por um organismo independente da relação comercial com o objetivo de atestar publicamente, por escrito, que determinado produto, processo ou serviço está em conformidade com os requisitos especificados. Podem ser normas nacionais, estrangeiras ou internacionais.

O conjunto ótico é parte de uma luminária e é composto de refletor e aleta: A1, B1 e C1. Não faz parte do connjuto ótico o corpo da luminária. Neste trabalho o conjunto ótico é o objeto de ensaio.

Aparência de um objeto que depende da composição espectral da luz incidente, do fator espectral de refletância ou de transmissão do objeto e da resposta espectral de um observador.

O corpo da luminária é o chassi da luminária, normalmente confeccionada em chapa de aço tratada com acabamento em pintura eletroestática epóxi pó na cor branca. É a parte que fixa e sustenta o refletor, aleta, porta-lâmpadas, lâmpadas e equipamento auxiliar.

Acabamento colorido, produzido, por exemplo, pela imersão de uma camada de óxido anódica não selada em um banho com corante adequado, ou em uma solução produtora de pigmento.

De uma fonte, é a curva traçada sobre uma esfera imaginária com centro no meio luminoso da fonte, e ligando todos os pontos correspondentes às direções que têm a mesma intensidade luminosa, ou uma projeção dessa curva sobre um plano.

Nota: o termo "curva isocandela", anteriormente utilizado, está obsoleto.

Lugar geométrico dos pontos de uma superfície nos quais a iluminância tem o mesmo valor.

Nota: o termo "curva isolux", anteriormente utilizado, está obsoleto.

Gráfico formado por uma rede de curvas de isointensidade. 
Distância de ensaio

Eficiência luminosa

Fator de perdas luminosas

Fator de fluxo de um reator

Fator de manutenção do fluxo luminoso (de uma lâmpada)

Fator de utilização

Fluxo acumulado

Fluxo luminoso
Para medições fotométricas, é a distância entre o centro luminoso de uma fonte e a superfície do detector.

É a capacidade de conversão de energia elétrica em luminosa, expressa pela razão entre o fluxo luminoso emitido por uma fonte de luz (em lumens) e a potência elétrica consumida por essa mesma fonte (em Watts). Unidade: $\operatorname{Im} / \mathrm{W}$.

Razão da iluminância média no plano de trabalho após certo tempo de utilização de uma instalação de iluminação, para a iluminância média obtida nas mesmas condições para a instalação considerada nova.

Notas:

a) o termo "fator de depreciação" era utilizado anteriormente para designar o inverso da razão acima;

b) as perdas luminosas consideram a acumulação de poeira nas luminárias e nas superfícies do compartimento, e também a depreciação das lâmpadas;

c) o termo "fator de manutenção", anteriormente utilizado e considerado obsoleto, volta a ser utilizado.

Razão do fluxo luminoso emitido por uma lâmpada de referência, funcionando com reator comercial, para o fluxo luminoso emitido pela mesma lâmpada quando funcionando com o reator de referência.

Razão do fluxo luminoso em dado momento da vida de uma lâmpada, para o seu fluxo nominal inicial, com a lâmpada funcionando em condições especificadas.

Nota: essa razão é geralmente expressa em porcentagem. De uma instalação de iluminação e em relação a uma superfície de referência dada, é a razão do fluxo luminoso recebido pela superfície de referência, para a soma dos fluxos luminosos das lâmpadas individuais da instalação. De uma fonte e para um ângulo sólido dado, é o fluxo luminoso emitido, nas condições de funcionamento especificadas, no interior de um cone com eixo vertical dirigido para baixo, e que encerra esse ângulo sólido.

Valor de fluxo luminoso inicial de um dado tipo de 
nominal (de um tipo de lâmpada)

Fluxo luminoso inicial (de uma lâmpada)

Fotometria

\section{Fotômetro}

Goniofotômetro

Índice de reprodução

de cor

Intensidade luminosa

(ly ,I)

\section{Iluminação}

Iluminância $\left(E_{y}, E\right)$

Iluminância mantida (Ëm) lâmpada, declarado pelo fabricante ou pelo fornecedor responsável, com a lâmpada funcionando em condições especificadas. Unidade: lumén - Im.

Fluxo luminoso após o tempo de sazonamento da lâmpada, definido por norma pertinente.

Medição das grandezas relativas às radiações, avaliadas de acordo com uma dada função de eficácia luminosa espectral.

Instrumento destinado a medir grandezas fotométricas.

Fotômetro destinado a medir a distribuição angular de uma grandeza luminosa característica de uma fonte, de uma luminária, de um meio ou de uma superfície.

Avaliação quantitativa do grau das cores psicofísicas de um objeto iluminado, sob ensaio, pelo iluminante, e a do mesmo objeto iluminado pelo iluminante de referência, sendo o estado de adaptação cromática considerado de maneira correta.

De uma fonte, numa dada direção, é a razão do fluxo luminoso de Фy que sai da fonte e se propaga no elemento de ângulo sólido, cujo eixo coincide com a direção considerada para esse elemento de ângulo sólido: Unidade: candela - cd.

Aplicação de luz a uma cena e/ou objetos, e suas circunvizinhanças, para que possam ser vistos de maneira adequada.

Nota: este termo é também utilizado, na linguagem corrente, com o sentido de "sistema de iluminação" ou "instalação de iluminação".

Em um ponto de uma superfície, é a razão do fluxo luminoso, incidente num elemento da superfície que contém, pela área deste elemento, o ponto dado.

Unidade: lux-Ix

Valor abaixo do qual a iluminância média da superfície especificada não poderá ser reduzido. 
Jateamento abrasivo

Lâmpada

Lâmpada de

referência

Lâmpada - padrão

secundário

Lâmpada fluorescente

\section{Luminância}

Luminancímetro

Luminária

Luminária de ensaio
Tratamento de superficie por projeção de particulas como, por exemplo, alumina, glóbulos, areia ou vidro projetado por corrente de ar. Pode ser realizado com abrasivos finos suspensos em água ou outros liquidos (úmidos ou vapor)

Fonte fabricada a fim de produzir luz.

Lâmpada de descarga escolhida para a finalidade de ensaiar reatores de lâmpadas de descarga, e que, quando associada a um reator de referência sob condições especificadas, tem características elétricas próximas dos valores procurados que constam da norma pertinente.

Lâmpada destinada a servir como padrão fotométrico secundário.

Lâmpada de descarga em que a maior parte da luz é emitida por uma camada de material fluorescente, excitada pela radiação ultravioleta de descarga.

(Numa dada direção, num ponto na superfície de uma fonte ou receptor, ou num ponto no caminho do facho). Quociente do fluxo luminoso, saindo, chegando ou passando através de elemento de superfície neste ponto e propagado em direções definidas num cone elementar contendo a direção dada, pelo produto do ângulo sólido do cone e a área de projeção ortogonal do elemento de superfície num plano perpendicular à essa direção.

Unidade: candela por metro quadrado, $\mathrm{cd} / \mathrm{m}^{2}$.

Instrumento destinado a medir luminância.

Aparelho que distribui, filtra ou modifica a luz emitida por uma ou mais lâmpadas, e que contém, exclusive as próprias lâmpadas, todas as partes necessárias para fixar e protegê-las e, quando necessário, os circuitos auxiliares e os meios de ligação ao circuito de alimentação.

Adotada como padrão de iluminação para os ensaios dos conjuntos óticos de referência em laboratório e das instalações de campo. Modelo de sobrepor CS-656 para duas lâmpadas fluorescentes tubulares T5 28W e reator 
eletrônico.

\section{Luminosidade}

Luxímetro

Luz artificial

Luz natural

Manutenção

Norma técnica

Normalização

Oxidação quimica

Polimento químico

Potência nominal (de um tipo de lâmpada)
Atributo da sensação visual segundo a qual uma superfície parece emitir mais ou menos luz.

Instrumento destinado a medir iluminância.

Obtida através de fontes luminosas como as lâmpadas, que geram luz através de eletricidade.

É a parte visível da radiação solar.

Os níveis de iluminação recomendados para cada tarefa são fornecidos como iluminância de manutenção. A iluminância de manutenção depende das características de manutenção da lâmpada, da luminária, do ambiente e do programa de manutenção. O projeto de iluminação deve ser desenvolvido com o fator de manutenção total calculado para o equipamento de iluminação selecionado, para o tipo de ambiente e para o cronograma de manutenção especificado. Não se recomenda que o fator de manutenção calculado seja inferior a 0,70. Recomendase consultar norma CIE 97/2005.

Norma é o documento técnico que estabelece as regras e características mínimas que determinado produto, serviço ou processo deve cumprir, permitindo uma perfeita ordenação e a globalização dessas atividades ou produtos.

Atividade que estabelece, em relação a problemas existentes ou potenciais, prescrições destinadas à utilização comum e repetitiva com vistas à obtenção do grau ótimo de ordem em um dado contexto.

Formação de um filme óxido sobre a superficie do metal pela ação de agentes oxidantes quimicos.

Polimento de uma superfície por imersão em uma solução de reagentes químicos.

Valor da potência de um tipo de lâmpada, declarado pelo fabricante ou fornecedor responsável, com a peça funcionando em condições especificadas. 
Unidade: watts $-\mathrm{W}$.

Reator

Refletância (fator de reflexão)

Refletor

Refletor especular

Reflexão

Reflexão especular

Reflexão difusa

Rendimento óptico

Rendimento (de uma luminária)

Sistema ótico

Tarefa visual

Temperatura de cor
Dispositivo usado com lâmpada de descarga para estabilizar a corrente na descarga.

Razão do fluxo radiante ou refletido pelo fluxo incidente.

Dispositivo destinado a modificar a distribuição espacial do fluxo luminoso emitido por uma fonte de luz, essencialmente por meio do fenômeno reflexão.

Parte de uma luminária, desenhado para refletir o fluxo luminoso das lâmpadas nas direções requeridas, por meio de reflexão especular.

Devolução de radiação por uma superfície, sem modificação da frequência dos componentes monocromáticos, nos quais a radiação é composta.

Reflexão sem difusão de acordo com as leis de reflexão óptica, como um espelho.

Difusão por reflexão, na qual, sob uma escala monocromática, não há reflexão regular.

Razão do fluxo total de uma luminária, medido em condições especificadas, para a soma dos fluxos luminosos das lâmpadas individuais, quando estas estão dentro da luminária.

Razão do fluxo total emitido pela luminária, medido em condições práticas especificadas e com suas próprias lâmpadas e equipamentos, para a soma dos fluxos luminosos das lâmpadas individuais funcionando fora da luminária, com os mesmos equipamentos e em condições especificas.

O sistema ótico é o conjunto do corpo da luminária, refletor e aleta.

Os elementos visuais da tarefa a ser realizada.

É uma escala que apresenta numericamente a relação entre a cor da luz emitida por um determinado corpo de prova (corpo negro) e a luz emitida por uma fonte artificial. Unidade: K (Kelvin) 
Tempo de

acendimento

Tensão de

acendimento

Tensão de

funcionamento

Utiliância

Vida (de uma

lâmpada)

Vida média
Tempo necessário para que uma lâmpada estabeleça uma descarga em arco eletricamente estável, com a peça funcionando em condições especificadas, e o tempo sendo medido a partir do instante em que o circuito é energizado.

Tensão entre os eletrodos necessária para iniciar a descarga numa lâmpada.

Tensão entre os eletrodos durante o funcionamento de uma lâmpada de descarga, em condições estáveis (valor eficaz no caso de corrente alternada).

De uma instalação de iluminação, e em relação a uma superfície de referência dada, é a razão do fluxo luminoso recebido pela superfície de referência, para a soma dos fluxos totais das luminárias individuais da instalação. Unidade: (U)

Tempo durante a qual a lâmpada funciona até se tornar inútil, ou ser considerada inútil de acordo com critérios especificados.

Nota: a vida de uma lâmpada é expressa em horas.

Média das vidas individuais das lâmpadas submetidas ao ensaio de vida, com as lâmpadas funcionando em condições especificadas, e o fim da vida sendo julgado de acordo com critérios especificados. 


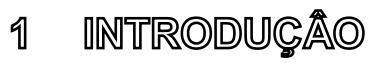

\subsection{Considerações iniciais}

Com a criação do Programa Nacional de Conservação de Energia Elétrica (PROCEL), em dezembro de 1985, foi incrementado em nosso meio o conceito de conservação de energia elétrica, ou seja, de combate ao desperdício de energia (MOREIRA, 1999).

O conceito de eficiência energética pode ser entendido como a obtenção de um serviço com baixo dispêndio de energia elétrica. Portanto, um edifício é mais eficiente energeticamente que outro quando proporciona as mesmas condições ambientais com menor consumo de energia (LAMBERTS, DUTRA, PEREIRA, 1997).

Muitas campanhas contra o desperdício surgem diariamente. Novas tecnologias são adotadas, bem como são criados equipamentos de baixo consumo e maior eficiência energética. Entretanto, além da utilização destes recursos, visualiza-se a necessidade da elaboração de regulamentações, fiscalização e acompanhamento efetivos, como também que os arquitetos e engenheiros tenham mais conhecimento sobre eficiência energética ao nível do projeto ou da especificação de materiais e equipamentos, pois os desperdícios podem ser reduzidos na fase de concepção do projeto, evitando a necessidade de maior produção de eletricidade no país. É mais fácil economizar energia do que fornecê-la (GELLER, 1994). Trata-se de uma constante busca, pois gerar energia está diretamente relacionado ao grande impacto ambiental causado pela construção de novas usinas, deslocamento de populações inteiras para a instalação de hidroelétricas, inundações, poluição e riscos com a segurança pública, isto quando na construção de termoelétricas e usinas nucleares.

Hoje, deparamo-nos com uma grande preocupação, que é a necessidade de encontrar a melhor dinâmica entre o modelo ideal de conservação de energia elétrica e de desenvolvimento sustentável. Qualquer atividade construtiva comporta a utilização, redistribuição e concentração de alguns recursos energéticos e de materiais retirados do planeta.

Construir é uma função humana natural, mas implica numa tarefa de planejamento e esboço ambiental, gerenciamento de recursos e ecologia aplicada (YEANG, 2001). 


\subsection{Motivação e justificativa}

Conforme dados da Eletrobrás (2009), da energia elétrica consumida no Brasil, $42 \%$ é utilizada por edificações residenciais, comerciais e públicas, sendo que, no setor residencial, o consumo de energia chega a $23 \%$ do total nacional, chegando a $11 \%$ nos setores comerciais e a $8 \%$ no público. Isto se dá principalmente em forma do consumo de energia em iluminação artificial, tornando-se assim necessária a conscientização da indústria, dos designers de produtos, dos projetistas de iluminação e dos grandes consumidores e a busca constante de matérias-primas, tecnologias e soluções de iluminação energeticamente eficientes.

A significativa parcela de energia consumida por essas edificações pode ser controlada, evitando-se um aumento exagerado, por meio de soluções que, mesmo aparentemente mais onerosas, mostram-se viáveis a médio ou longo prazo, garantindo o conforto do usuário a um menor custo. Um bom exemplo é maximizar o uso de equipamentos e luminárias mais eficientes.

Alguns trabalhos realizados mostram que o refletor em alumínio eleva a eficiência da iluminação. Segundo GHISI, LAMBERTS, 1998, "as luminárias com refletor em alumínio sem aletas representam a melhor solução em termos de minimização de carga instalada em iluminação, seguidas muito próximas pelas luminárias com refletor de alumínio e aletas brancas". Neste estudo, verificou-se que as luminárias com difusor são as que exigem maior carga em iluminação, podendo ser 55,3\% superior às luminárias com refletor de alumínio sem aletas.

As referências na literatura sobre sistemas de iluminação são extensas e abrangentes; diferentemente do que ocorrem sobre o fator de manutenção dos sistemas de iluminação, as informações são escassas e não mostram a condição real dos fatores de manutenção ou depreciação aplicados pelos projetistas da iluminação, a fim de que seja levada em consideração a devida depreciação, conforme o tempo de funcionamento e o fluxo luminoso entregue inicialmente à instalação, que diminui com o envelhecimento das lâmpadas e do acúmulo de sujeira nas luminárias. 
Outra condição pouco explorada neste aspecto é a corrosão que ocorre nos refletores óticos, quando estes sistemas estão instalados em ambientes críticos, com alto grau de depreciação gerado, muitas vezes, pela própria atividade, como por exemplo, indústria, garagem, ou até devido à localização da instalação, como no caso de orla marítima, proximidade com áreas de grande concentração de indústrias de fundição, química e siderurgia, com poluentes diversos e gases dissolvidos.

Cada instalação sofre uma depreciação durante o uso, conforme aplicação, localização e agentes externos, mas normalmente nos preocupamos com os aspectos iniciais de eficiência energética de nossas instalações, e muito pouco com o fator manutenção dado a elas ao longo do seu uso.

O acúmulo de poeira no corpo ótico das luminárias é um agravante de depreciação, pois o enegrecimento da parte refletora diminui a saída de luz, o rendimento e, gradativamente, a quantidade de luz encaminhada para o ambiente.

Segundo SANTAMOURIS, 1998, a falta de manutenção em luminárias pode reduzir o fluxo luminoso em $30 \%$, porém, dados do IESNA ${ }^{1}$ (1995) indica que a falta de manutenção em luminárias pode reduzir a iluminância entre 25\% a 50\%, dependendo da aplicação e equipamentos usados, pois a depreciação também está diretamente ligada à perda de fluxo luminoso das lâmpadas, uma vez que parte depende da substituição conforme a vida útil ou vida física.

\subsection{Objeto}

O objeto desta pesquisa entende-se por conjuntos óticos compostos por refletores e aletas, denominados de: R A1, R B1, R C1, FA A1, FA B1, FA C1, LU A1, LU B1, LU C1, PO A1,PO B1 e PO C1.

\subsection{Objetivos}

Os objetivos deste trabalho são divididos em gerais e específicos.

\footnotetext{
${ }^{1}$ IESNA - Illuminating Engineering Society of North America.
} 


\subsubsection{Objetivos Gerais}

- Verificar a influência das características reflexivas do refletor com diferentes tratamentos de superfícies;

- Analisar comparativamente o desempenho e as perdas luminosas dos sistemas óticos;

- Estabelecer as melhores alternativas que representem efetivamente ganhos de qualidade de luz e eficiência energética; e

- Examinar o fator de perdas luminosas aplicado pelo projetista de iluminação.

\subsubsection{Objetivos específicos}

- Analisar a contribuição dos diferentes tratamentos de superfícies dados aos refletores de alumínio, em relação ao desempenho, estética, vida útil e proteção contra agressões ambientais;

- $\quad$ Conhecer os parâmetros de perdas luminosas dos corpos óticos aplicados em distintas instalações;

- llustrar que padrões de alumínio de alto rendimento, com capacidade reflexiva entre $82 \%$ e 95\%, baixa depreciação e associados a sistemas óticos de alto desempenho, são a garantia de boa qualidade da luz associada à economia de energia;

- Examinar se as perdas luminosas são superiores aos valores utilizados hoje como critério de controle do sistema de iluminação, atendendo às recomendações da Norma NBR 5413/1992 ${ }^{2}$ que indicam que a iluminância em qualquer ponto do campo de trabalho não seja inferior a 70\% da iluminância média; e

- Avaliar se as perdas luminosas são superiores às recomendadas pela futura Norma NBR ISO $8995-1^{3}$, que deverá entrar em vigor em 2013, e da Norma CIE 97/2005 , que determina que a iluminância de manutenção dependa das características de manutenção da lâmpada, da luminária, do ambiente e do programa de manutenção, e que recomenda que o fator de manutenção calculado seja inferior a 0,70.

\footnotetext{
${ }^{2}$ NBR 5413/1992 - lluminação de interiores.

${ }^{3}$ NBR ISO 8995-1 -- lluminação de ambientes de trabalho.

${ }^{4}$ CIE 97/2005 - Maintenance of Indoor Electric Lighting Systems.
} 


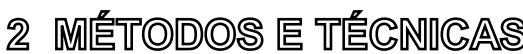

\subsection{Introdução}

Os procedimentos metodológicos desta dissertação tiveram início com um amplo levantamento de dados secundários, seguido de um levantamento de dados primários, por meio de experimentações e medições para a determinação de indicadores de perdas de intensidades luminosas de conjuntos óticos de luminárias para o setor comercial ${ }^{5}$, e, consequentemente, de uma série de conclusões de resultados, como demonstrado na Figura 1.

As perdas de intensidades luminosas das lâmpadas fluorescentes tubulares, do reator eletrônico e da luminária não são de interesse deste estudo, mas exclusivamente os conjuntos óticos refletores.

Figura 1 - Fluxograma geral da pesquisa.

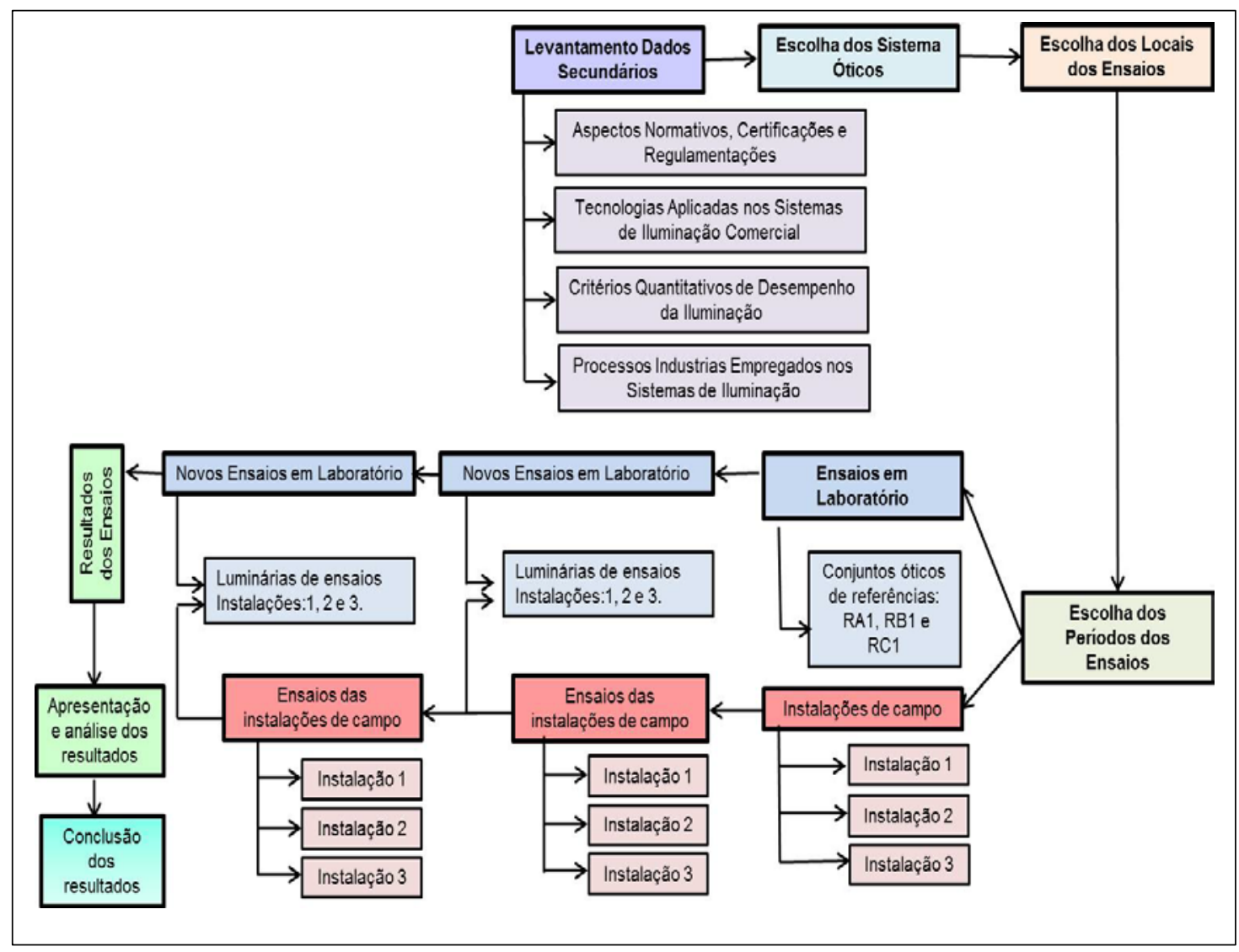

Fonte: a autora, 2013.

\footnotetext{
${ }^{5}$ Setor comercial: abrange uma série de subsetores, como o de comércio de bens e serviços, financeiro, turismo e hotelaria, educação e lazer, entre outros. Fonte. BEN Balanço Energético Nacional.
} 


\subsection{Levantamento de dados secundários}

Esta pesquisa foi realizada por meio de revisão bibliográfica em dissertações, teses, artigos científicos e jornalísticos, relatórios técnicos, normas técnicas, certificações e regulamentações e outras publicações relacionadas ao tema. A título de exemplificação as principais fontes de referência do ponto de vista normativo que embasaram esta pesquisa:

- ABNT NBR 14155/2010- Alumínio e suas ligas - Tratamento de superfície - Camada de anodização dura - Determinação da microdureza;

- ABNT NBR NM ISO 2107/2008 - Alumínio e suas ligas - Produtos trabalháveis - Designação das têmperas;

- ABNT NBR ISO 7583/2010 - Anodização do alumínio e suas ligas Vocabulário;

- ABNT NBR ISO 7823/2010 - Alumínio e suas ligas - ChapasPropriedades mecânicas;

- ABNT NBR 12611/1992 - Determinação da espessura da camada anódica pelo método de microscopia óptica.

- ABNT NBR 8095/1983 - Material metálico revestido e não revestido, corrosão por exposição à atmosfera úmida saturada;

- ASTM E1651-94/1999 - Standard Test Method for Total Luminous Reflectance Factor by Use of 30/t Integrating-Sphere Geometry;

- CIE 97/2005 - Maintenance of Indoor Electric Lighting Systems;

- DIN 67530 - Reflectometer as a means for gloss assessment of plane surfaces of paint coatings and plastics;

- DIN 5031-1- Optical radiation physics and illuminating engineering; quantities, symbols and units of radiation physics;

- DIN 5031-2 - Optical radiation physics and illuminating engineering; evaluation of radiation by different detectors;

- DIN 5031-3 - Optical radiation physics and illuminating engineering; quantities;

- DIN 5036-3 - Radiometric and photometric properties of materials; methods of measurement for photometric and spectral radiometric 
- characteristics - já aplicada em estudos realizados no IPT pelo Laboratório de Equipamentos Elétricos e Ópticos;

- ASTM B-117 - Method of Salt Spray (Fog) - já aplicada em estudos realizados no IPT pelo Laboratório de Corrosão e Proteção;

- ASTM D2247- 2 - Standard Practice for Testing Water Resistance of Coatings in 100\% Relative Humidity - já aplicada em estudos realizados no IPT pelo Laboratório de Corrosão e Proteção;

- Para demais referências secundárias de consulta, vide referências bibliográficas.

\subsection{Escolha dos sistemas óticos}

A escolha dos sistemas óticos foi baseada na análise das características e propriedades reflexivas de três conjuntos óticos ${ }^{6}$ com distintos acabamentos de superfícies de alumínios especulares. Estas propriedades reflexivas foram avaliadas por meio da análise das informações dos acabamentos, ligas, dureza, reflexão especular, reflexão difusa e reflexão total TR2, sendo que, os modelos escolhidos estão entre $75 \%$ e $95 \%$.

Figura 2 - Luminária composta por um corpo e um conjunto ótico (refletor e aleta).

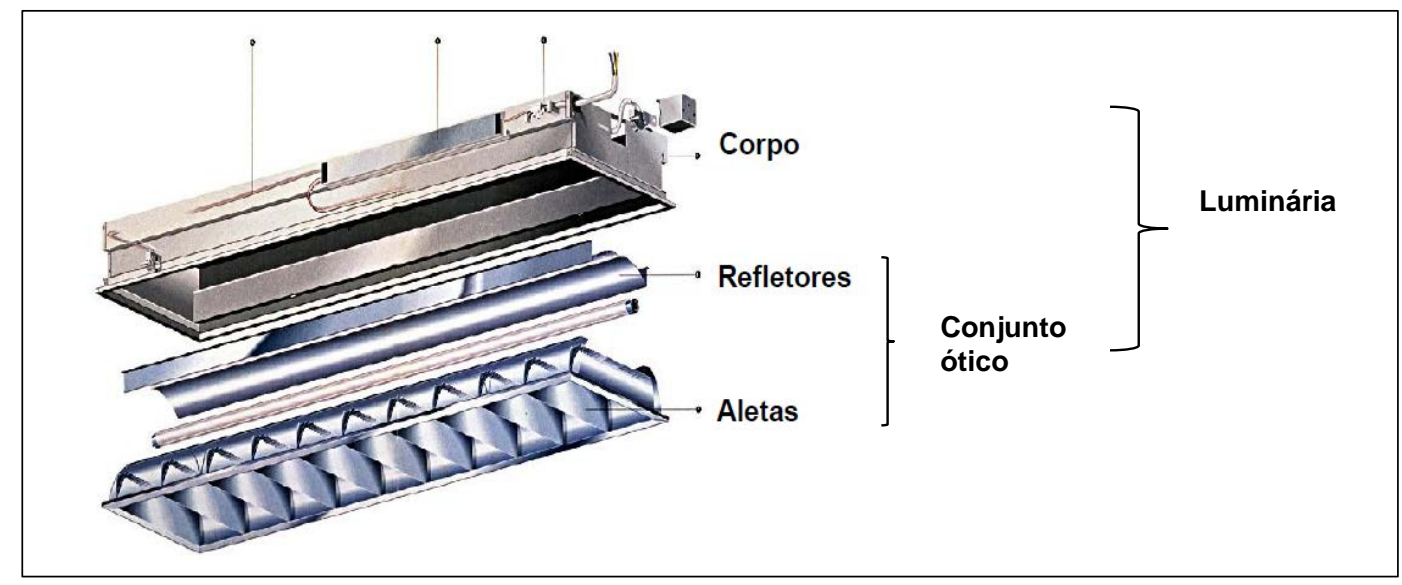

Fonte: RUSCHER, 2009.

${ }^{6}$ Conjunto ótico - O conjunto ótico é parte de uma luminária e é composto de refletor e aleta: A1, B1 e C1. Não faz parte do conjunto ótico o corpo da luminária. Neste trabalho o conjunto ótico é o objeto de ensaio. 
2.3.1. Características dos conjuntos óticos de ensaios.

O objeto deste estudo é a analise do desempenho ótico e das perdas luminosas dos conjuntos óticos, exemplificado na figura 3 e conforme identificação a seguir:

$\rightarrow$ Conjunto ótico A1 - Alumínio Nacional.

Tratamento da superfície: Sem tratamento de superfície do alumínio.

Característica do acabamento: Especular.

Reflexão total: $75 \%-85 \%{ }^{7}$.

Fabricante: ALCOA do Brasil.

Procedência: Brasil.

$\rightarrow$ Conjunto ótico B1 - Alumínio 100/030/B

Tratamento da superfície: Por processo de anodização.

Característica do acabamento: Especular.

Reflexão total: $85 \%$ - 86\%

Fabricante: ALMECO S.p.A.

Procedência: Milão, Itália.

$\rightarrow$ Conjunto ótico C1 - Alumínio VEGA 95100

Tratamento da superfície:Por processo de PVD (Physical Vapour Deposition).

Característica do acabamento: Especular.

Reflexão total : 95\%.

Fabricante: ALMECO S.p.A.

Procedência: Bernburg, Alemanha.

\footnotetext{
${ }^{7}$ Reflexão total estimada 75-85\%- Dados obtidos em ensaios anteriores pela LUCCHI Ltda., com o acompanhamento da autora deste trabalho nos Laboratórios de Fotometria do INMETRO, no Rio de Janeiro, 2007. A indústria nacional divulga valores semelhantes. Fonte: Catálogo ALCOA - Bright products technical (2012).
} 
Figura 3 - Modelo do conjunto ótico adotado para os ensaios.

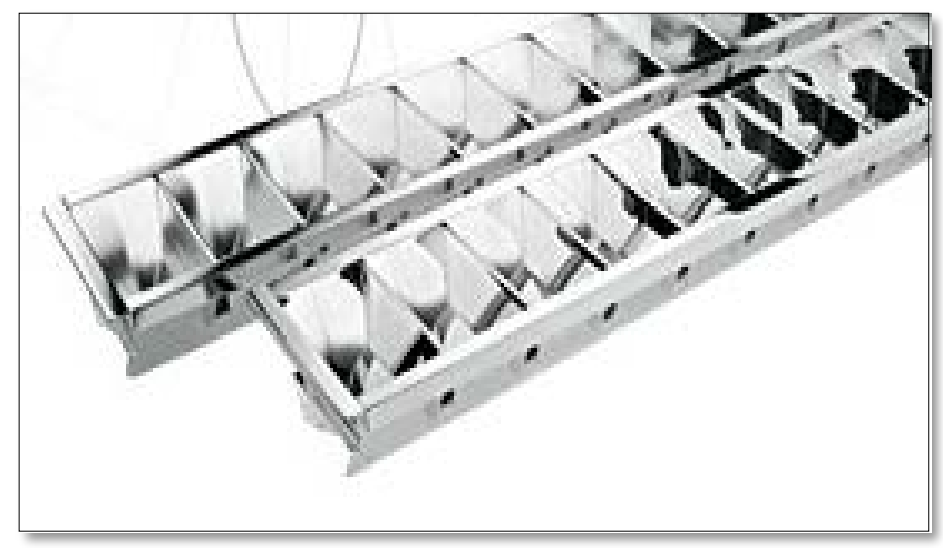

Fonte: ALMECO, 2011.

A Tabela 1 ilustra as propriedades dos alumínios utilizados nos conjuntos óticos, sendo que, conforme a Norma NBR 6834, a liga do alumino nacional é 1050 com 99,50\% de $\mathrm{Al}^{8}$, o modelo 100/030/B utiliza liga 1085 de pureza 99,85\% de Al., e o modelo VEGA 95100 a liga 1085 com 99,99\% de Al. A seguir na tabela 2 , é apresentada as propriedades reflexivas dos modelos de alumínios empregados nos conjuntos óticos.

Tabela 1 - Propriedades dos alumínios empregados nos conjuntos óticos.

\begin{tabular}{|c|c|c|c|c|}
\hline Modelo & Tipol Acabamento & Alumínio/liga & Pureza da camada & Dureza \\
\hline A 1 & Especular & 1050 & Al 99,50 & H19 \\
\hline B 1 & Especular & 1085 & Al 99,85 & $\mathrm{H} 18$ \\
\hline C 1 & Especular & 1085 & Al 99,99 & $\mathrm{H} 18$ \\
\hline
\end{tabular}

Fonte: a autora, ALMECO, 2011.

${ }^{8} \mathrm{Al}$ - Símbolo do Alumínio. 
Tabela 2 - Propriedades reflexivas dos alumínios empregados nos conjuntos óticos.

\begin{tabular}{|l|c|c|c|}
\hline Modelos & A 1 & B 1 & C 1 \\
\hline Acabamento & Especular & Especular & Especular \\
\hline Reflexão Especular & $75-85 \%$ & 86 & $\geq 95$ \\
\hline $\mathbf{6 0}^{\circ}$ longitudinal & Dados não disponíveis & 82 & 89 \\
\hline $\mathbf{6 0}^{\circ}$ transversal & Dados não disponíveis & 80 & $<11$ \\
\hline Reflexão Difusa & Dados não disponíveis & 12 & $\geq 95$ \\
\hline Reflexão Total Tr2 & Dados não disponíveis & 86 & Sem iridescência \\
\hline Iridescência & Dados não disponíveis & Baixa iridescência & \\
\hline
\end{tabular}

Fonte: a autora, ALMECO, 2011.

\subsubsection{Características das luminárias de ensaios}

Para a execução dos ensaios em campo e medições em laboratório foi necessário à escolha de uma luminária para inserção do conjunto ótico, sendo o modelo eleito de fabricação da empresa Carolino Indústria e Comércio Ltda, sediada na região Sul da cidade de São Paulo. A escolha da luminária CS-656 é baseada na análise das características indicadas pelo fabricante, seu desenho e dimensões, conforme dados da Figura 4.

$\rightarrow$ Luminária modelo CS-656 de uso interno, de sobrepor, corpo em chapa de aço protegida contra ferrugem, com pintura eletrostática em epóxi pó na cor branca, para uso com duas lâmpadas fluorescentes tubulares T5, com potência nominal de 28 W e alojamento para reator eletrônico. (Catálogo Carolino Indústria e Comércio Ltda). 
Figura 4 - Luminária modelo CS-656, adotada como padrão, catálogo do fabricante Carolino Indústria e Comércio Ltda.

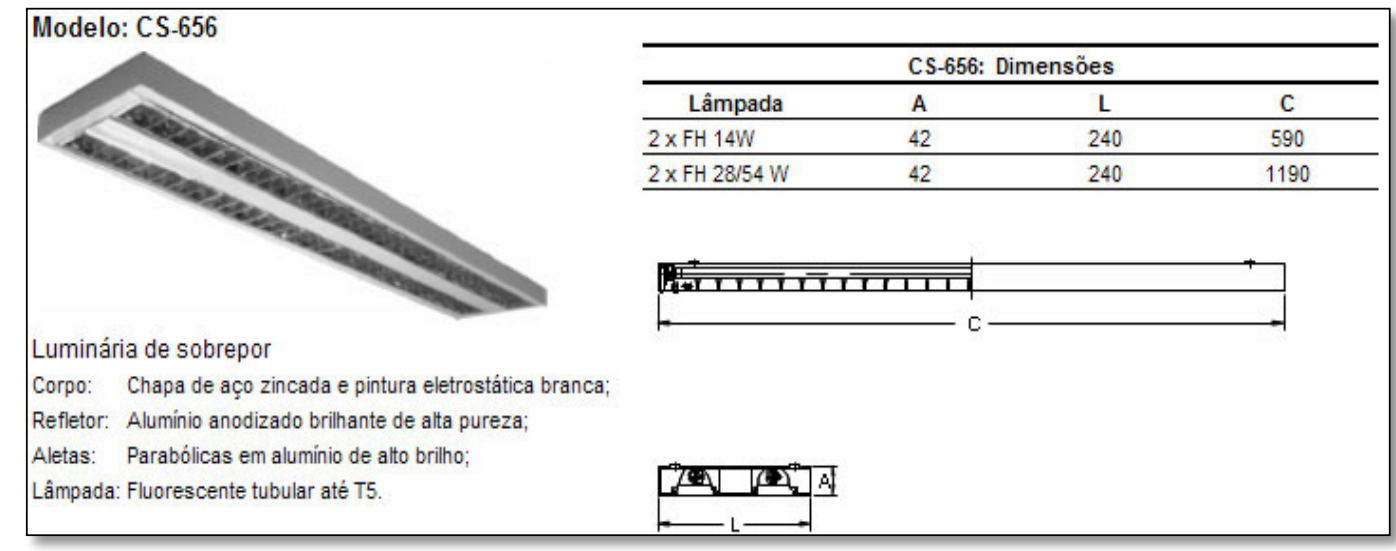

Fonte: Carolino Indústria e Comércio Ltda., 2011.

\subsubsection{Quantidades de luminárias de ensaios}

A quantidade de luminárias estudadas, conforme metodologia assumida para análise deste trabalho foi de 12 unidades, sendo três consideradas como conjuntos óticos de referência e nove para o levantamento de dados de campo e laboratório, como indicada na Tabela 3.

Tabela 3 - Quantidade de luminárias utilizadas para os ensaios de campo e laboratório.

\begin{tabular}{|c|l|}
\hline Modelo & \multicolumn{1}{|c|}{ Quantidades } \\
\hline A 1 & $\begin{array}{l}\text { 01 unidade para montagem do conjunto ótico de referência (ensaio } \\
\text { em laboratório) e } 03 \text { unidades (ensaios de campo). }\end{array}$ \\
\hline B 1 & $\begin{array}{l}\text { 01 unidade para montagem do conjunto ótico de referência (ensaio } \\
\text { em laboratório) e 03 unidades (ensaios de campo). }\end{array}$ \\
\hline C 1 & $\begin{array}{l}\text { 01 unidade para montagem do conjunto ótico de referência (ensaio } \\
\text { em laboratório) e 03 unidades (ensaios de campo) }\end{array}$ \\
\hline
\end{tabular}




\subsubsection{Características das lâmpadas fluorescentes tubulares de ensaios}

Lâmpadas - Duas lâmpadas fluorescentes tubulares T5 de alta eficiência, modelo LUMILUX T5 HE FH 28W/840 HE - marca OSRAM, fluxo luminoso nominal $2.600 \mathrm{Im}$, temperatura de cor T4.000K, índice de reprodução de cor: 80-89, base: G5, vida útil: 16.000 horas. ( Catálogo OSRAM do Brasil.)

\subsubsection{Características dos reatores eletrônicos de ensaios}

Reator eletrônico - Reator eletrônico modelo QUICKTRONIC PROFESSIONAL, QTP5 2x14-35/230-240V, marca OSRAM, tensão de alimentação: $230 \mathrm{~V}$ - 240V, frequência: $50 / 60 \mathrm{HZ}$. (Catálogo OSRAM do Brasil)

\subsection{Escolha da localização onde foram realizados os ensaios}

Diante do uso em grande escala no Brasil de luminárias fluorescentes tubulares T5 (OSRAM,2011), especificamente em ambientes com características laborativas, optou-se em analisar três instalações próximas à cidade de São Paulo, com distintas condições de agentes externos $^{9}$. Nestas localidades foram feitas as instalações das luminárias de ensaios, com perfis metálicos ou cabos de suspensão para fixação nas eletrocalhas e plugues macho e fêmea para a conexão elétrica. O objetivo é o de facilitar a instalação, retirada e a reposição das mesmas, sem dificuldades no manuseio e sem danificá-las, principalmente os sistemas óticos, objeto do estudo.

\footnotetext{
${ }^{9}$ Agentes externos - Condições externas na atmosfera, que podem agredir e deteriorar o sistema ótico das luminárias, tais como, poeira, poluentes químicos, sais em suspensão, gases industriais, água do mar de alta concentração de elementos químicos que aceleram os processos corrosivos.
} 
$\rightarrow \quad$ Instalação 1 - FASA Fibra Ótica Ltda.

Av. Marginal FEPASA, 70 - Três Marias - Peruíbe - SP - Brasil.

Caracterítica da instalação - Indústria sediada no litoral paulista.

Agente externo - Ambiente marinho devido à atmosfera

contaminada com sal, alta umidade, poucos gases industriais e

poeira (PONTE, 2011). A instalação está a $1.500 \mathrm{~m}$ da orla marítima de Peruíbe.

Meio corrosivo - Considerado elevado.

$\rightarrow \quad$ Instalação 2 - Centro de Distribuição LUCCHI Ltda.

Rua Santa Mônica 1.414 - Pq. Industrial San José - Cotia - SP Brasil.

Caracterítica da instalação - Centro de distribuição na região metropolitana de São Paulo.

Agente externo - Ambiente com poucos gases industriais e poeira, média umidade de ar (PONTE,2011). Instalação a $1.000 \mathrm{~m}$ da Rodovia Raposo Tavares dentro de um parque industrial voltada armazenagem.

Meio corrosivo - Considerado baixo

$\rightarrow \quad$ Instalação 3 - Condomínio PORTO DE IBIÚNA.

Rodovia SP 250 - Ibiúna - SP - Brasil

Característica da instalação - Condomínio residencial a $8.000 \mathrm{~m}$ da Rodovia Bunjiro Nakao - SP 250, no interior de São Paulo.

Agente externo - Ambiente com poucos gases industriais e poeira, elevada umidade de ar, devido ser uma região com alta oncentração de vegetação (PONTE, 2011). Proximidade com a represa Itupararanga.

Meio corrosivo - Considerado médio. 


\subsection{Escolha dos períodos para a realização dos ensaios em campo e laboratório}

Para obtenção dos parâmetros que foi necessário uma análise criteriosa de indicadores de manutenção, de fatores de perdas luminosas e do desempenho fotométrico dos distintos tipos de alumínios nas instalações e na falta de referências bibliográficas que subsidie as informações dos prazos mínimos para a avaliação dos sistemas, assumimos em adotar 03 etapas de medições em laboratório totalizando 18 meses e 02 etapas de ensaios de campo, dentro de um período de médio de 2.640 horas a 2.856 horas

A escolha dos períodos para levantamento dos dados de campo para análise da depreciação dos conjuntos óticos das luminárias foi determinada considerando que o tempo mínimo provável para o comprometido das superfícies óticas, por meio do acumulo de poeira, de gases, de umidade, contaminação por parte de salinidade e outros meios corrosivos.

Por termos instalações com características administrativas, produtivas e de armazenamento, elegeu-se o uso de 8 horas/dia e em um período comercial de segunda-feira a sexta-feira.

\subsubsection{Ensaios em laboratório}

\subsubsection{Etapas de ensaios}

- Os ensaios foram divididos em três etapas, sendo que, as medições fotométricas executadas no laboratório da empresa Carolino Iluminação Indústria e Comércio Ltda.

- Etapa 1 - 0 h (zero) - Identificação e medições fotométricas dos conjuntos óticos de referências, conforme figura 5, que exemplifica os modelos adotados e a tabela 4 que apresenta o período de realização dos ensaios. Assumiu-se para este trabalho a necessidade do uso de lâmpadas 
de referência padrão secundário ${ }^{10}$ e de reator eletrônico de referência padrão secundário $^{11}$.

- Foi considerado para análise do desempenho fotométrico, o resultado da união de uma luminária de sobrepor modelo CS-656, os conjuntos óticos dos alumínios especulares $A 1, A 2$ e A3, as lâmpadas de referência padrão secundário FL028 e FL028A, e reator eletrônico de referência padrão secundário RE028. Os "conjuntos óticos de referências" estão identificados conforme exemplificado na Figura 5.

Figura 5- Conjuntos óticos de referências RA1, RB1 e RC1.

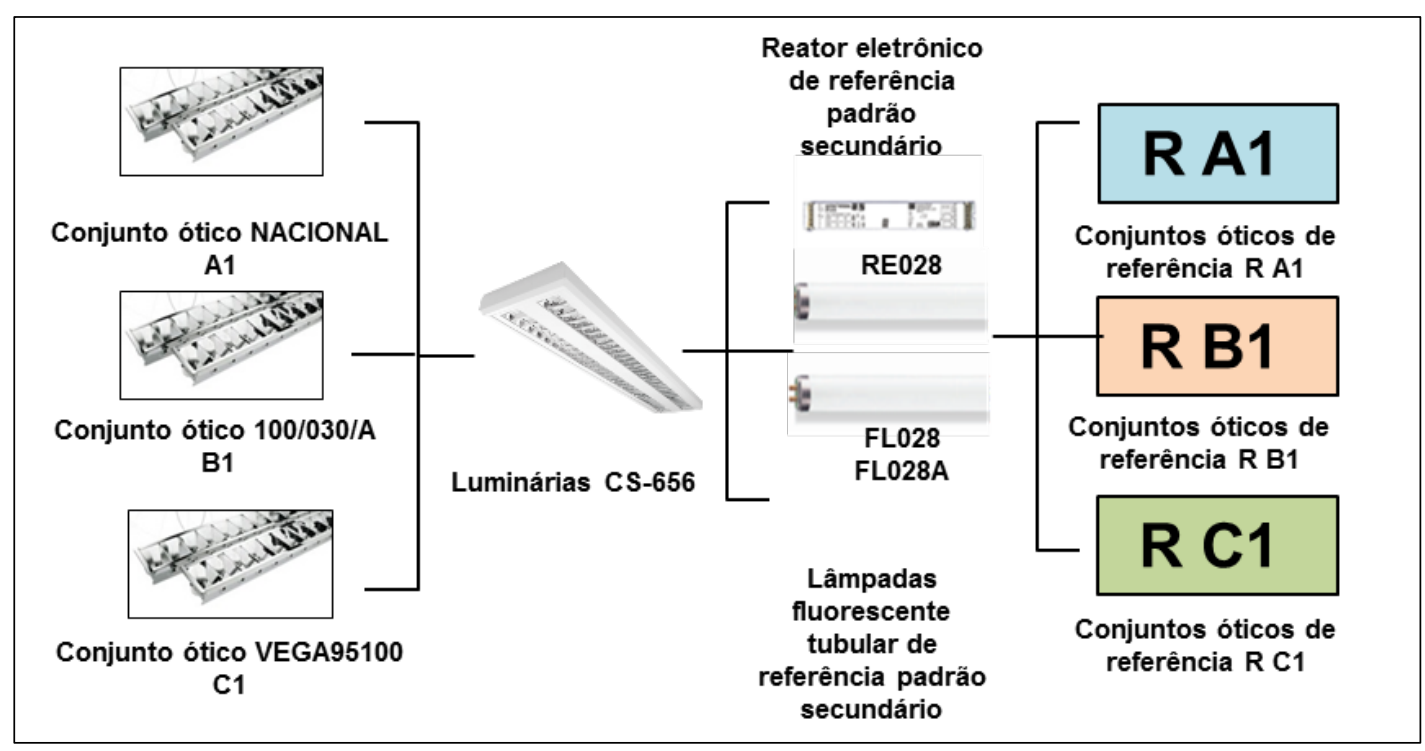

Fonte: a autora, 2013.

$\rightarrow$ Luminária modelo CS-656, com refletor em alumínio NACIONAL incorporado (A1) - Sem tratamento de superfície do alumínio - Refletor produzido com a utilização de alumínio sem anodização, identificado como fabricante NACIONAL; reflexão total estimada 75\%-85\% utilizando as lâmpadas de referência FL028 e FL028A e reator eletrônico de referência RE028.

\footnotetext{
10 Lâmpada padrão-secundário - Lâmpada destinada a servir como padrão fotométrico secundário, conforme Norma NBR 5461/1991- Iluminação - Terminologia.

11 Reator padrão secundário - Reator destinado a servir como padrão fotométrico secundário, conforme Norma NBR 5461/1991- Iluminação - Terminologia.
} 
- Códigos de identificação do conjunto de referência RA1.

$\rightarrow$ Luminária modelo CS-656 - Alumínio 100 - Com tratamento de préanodização do alumínio (B1) - Refletor produzido com a utilização de ALUMÍNIO MODELO 100/030/B, identificado como fabricante Grupo ALMECO, Milão, Itália, reflexão total $86 \%$, utilizando as lâmpadas de referência FL028 e FL028A e reator eletrônico de referência RE028.

- Códigos de identificação do conjunto de referência RB1

$\rightarrow$ Luminária modelo CS-656 - Alumínio VEGA 95100 (C1) - Com tratamento de pré anodizado por processo PDV (Physical Vapour Deposition). Refletor produzido com a utilização de ALUMíNIO VEGA 95100, identificado como Grupo ALMECO, Bernburg, Alemanha, reflexão total $\geq$ 95\%, utilizando as lâmpadas de referência FL028 e FL028A e reator eletrônico de referência RE028.

- Códigos de identificação do conjunto de referência $\mathrm{RC} 1$

$\rightarrow$ Lâmpadas de referência padrão-secundário (NBR 5461/1991) Medições iniciais em laboratório para a determinação da intensidade luminosa de uma lâmpada, em uma dada direção. Esse processo normalmente é feito através da comparação dessa lâmpada com uma lâmpada padrão, mas, neste caso, utilizamos duas lâmpadas fluorescentes tubulares T5 com potência individual nominal de $28 \mathrm{~W}$, marca OSRAM, modelo FHT5 28 W/840 HE, LUMILUX, diâmetro do tubo 16 mm, envelhecidas por 100 horas, com seus fluxos luminosos medidos até a total estabilização; as condições de tensão durante as medições foram controladas.

- Códigos de identificação das lâmpadas fluorescentes tubulares FHT5 28W/840, de padrão secundário: FL028 e FL028A. 
$\rightarrow$ Reator eletrônico padrão-secundário, modelo QTP 5 2x14-35W/230240V, marca OSRAM, modelo QUICKTRONIC PROFESSIONAL T5. O reator eletrônico de padrão-secundário terá a sua tensão controlada por um estabilizador de tensão e as informações serão controladas e registradas.

- Código de identificação do reator eletrônico de referência secundário: RE028.

Tabela 4 - Período das medições em laboratório da Etapa 1.

\begin{tabular}{|c|c|c|}
\hline $\begin{array}{c}\text { Tipo de alumínio/ Luminária/Lâmpadas e } \\
\text { Reator }\end{array}$ & Identificação & Data das Medições \\
\hline $\begin{array}{l}\text { Referência NACIONAL (A 1) + Luminária } \\
\text { CS-656 + RE028 + FL028 + FL028A. }\end{array}$ & R A1 & $\begin{array}{c}\text { 26/08/2011 ( } 1^{\circ} \text { ensaio)- } \\
\text { 01/06/2012 (novo ensaio } \\
\text { para confirmação das } \\
\text { medições) }\end{array}$ \\
\hline $\begin{array}{l}\text { Referência 100/030/B (B 1) + Luminária CS- } \\
656 \text { + RE028 + FL028 + FL028A. }\end{array}$ & R B1 & $\begin{array}{l}\text { 26/08/2011 (10 ensaio) - } \\
\text { 21/01/2013 (novo ensaio } \\
\text { para confirmação das } \\
\text { medições) }\end{array}$ \\
\hline $\begin{array}{l}\text { Referência VEGA } 95100 \text { (C 1) + Luminária } \\
\text { CS-656 + RE028 + FL028 + FL028A. }\end{array}$ & R C1 & $\begin{array}{c}\text { 26/08/2011 (10ensaio)- } \\
\text { 01/06/2012 (novo ensaio } \\
\text { para confirmação das } \\
\text { medições) }\end{array}$ \\
\hline
\end{tabular}

Fonte: a autora, 2013.

$\rightarrow \quad$ Etapa 2 - Retirada das instalações de campo: Instalações 1 FASA, Peruíbe, SP- (1.520 horas), Instalação 2 -LUCCHI, Cotia, SP ( 1.576 horas) e Instalação 3 - Condomínio PORTO de IBIÚNA, Ibiúna, SP ( 1.648 horas) para medições fotométricas em laboratório.

Tabela 5 - Período das medições em laboratório da Etapa 2.

\begin{tabular}{|l|c|c|c|}
\hline Localização & Tipo do Alumínio & Identificação & Datas das Medições \\
\hline FASA, Peruíbe, SP. & A 1 & FA A1 & $01 / 06 / 2012$ \\
\hline FASA, Peruíbe, SP. & B 1 & FA B1 & $01 / 06 / 2012$ \\
\hline
\end{tabular}




\begin{tabular}{|l|c|c|c|}
\hline FASA, Peruíbe, SP. & C 1 & FA C1 & $01 / 06 / 2012$ \\
\hline LUCCHI, Cotia, SP. & A 1 & LU A1 & $01 / 06 / 2012$ \\
\hline LUCCHI, Cotia, SP. & B 1 & LU B1 & $01 / 06 / 2012$ \\
\hline LUCCHI, Cotia, SP. & C 1 & LU C1 & $01 / 06 / 2012$ \\
\hline PORTO DE IBIÚNA, Ibiúna, SP. & A 1 & PO A1 & $02 / 06 / 2012$ \\
\hline PORTO DE IBIÚNA, Ibiúna, SP. & B 1 & PO B1 & $02 / 06 / 2012$ \\
\hline PORTO DE IBIÚNA, Ibiúna, SP. & C 1 & PO C1 & $02 / 06 / 2012$ \\
\hline
\end{tabular}

Fonte: a autora, 2013.

$\rightarrow \quad$ Etapa 3 - Retirada das instalações de campo: Instalações 1 FASA, Peruíbe, SP- (2.640 horas), Instalação 2 -LUCCHI, Cotia, SP ( 2.720 horas) e Instalação 3 - Condomínio PORTO de IBIÚNA, Ibiúna, SP ( 2.856 horas) para medições fotométricas em laboratório.

Tabela 6 - Período das medições em laboratório da Etapa 3.

\begin{tabular}{|l|c|c|c|}
\hline Localização & Tipo do Alumínio & Identificação & Datas das Medições \\
\hline FASA, Peruíbe, SP. & A 1 & FA A1 & $28 / 12 / 2012$ \\
\hline FASA, Peruíbe, SP. & B 1 & FA B1 & $28 / 12 / 2012$ \\
\hline FASA, Peruíbe, SP. & C 1 & FA C1 & $28 / 12 / 2012$ \\
\hline LUCCHI, Cotia, SP. & A 1 & LU A1 & $28 / 12 / 2012$ \\
\hline LUCCHI, Cotia, SP. & B 1 & LU B1 & $28 / 12 / 2012$ \\
\hline LUCCHI, Cotia, SP. & C 1 & LU C1 & $28 / 12 / 2012$ \\
\hline PORTO DE IBIÚNA, Ibiúna, SP. & A 1 & PO A1 & $28 / 12 / 2012$ \\
\hline PORTO DE IBIÚNA, Ibiúna, SP. & B 1 & PO B1 & $28 / 12 / 2012$ \\
\hline PORTO DE IBIÚNA, Ibiúna, SP. & C 1 & PO C1 & $28 / 12 / 2012$ \\
\hline
\end{tabular}

Fonte: a autora, 2013.

\subsubsection{Equipamentos utilizados no laboratório para as medições fotométricas}

$\rightarrow \quad$ Goniofotômetro manual para levantamento dos dados, usando como referência a publicação do IES LM-41-1985 - IES Approved Method for 
Photometric Testing of Indoor Fluorescent Luminaries. O goniofotômetro ou goniômetro (figuras 6 e 7) consta de uma estrutura provida de dois lombos graduados (Figuras 8 e 9), que permite a rotação do equipamento sob teste segundo eixo horizontal ou segundo eixo vertical. Para as medições das iluminâncias obtidas sobre a fotocélula do luxímetro, a distância considerada entre o centro do aparelho e do luxímetro foi de $6,00 \mathrm{~m}$, pois a distância deve ser no mínio cinco vezes a maior dimensão do aparelho sob teste, neste caso o comprimento da luminária é de $1.19 \mathrm{~m}$.

Figuras 6 e 7 - Goniofotômetro manual.

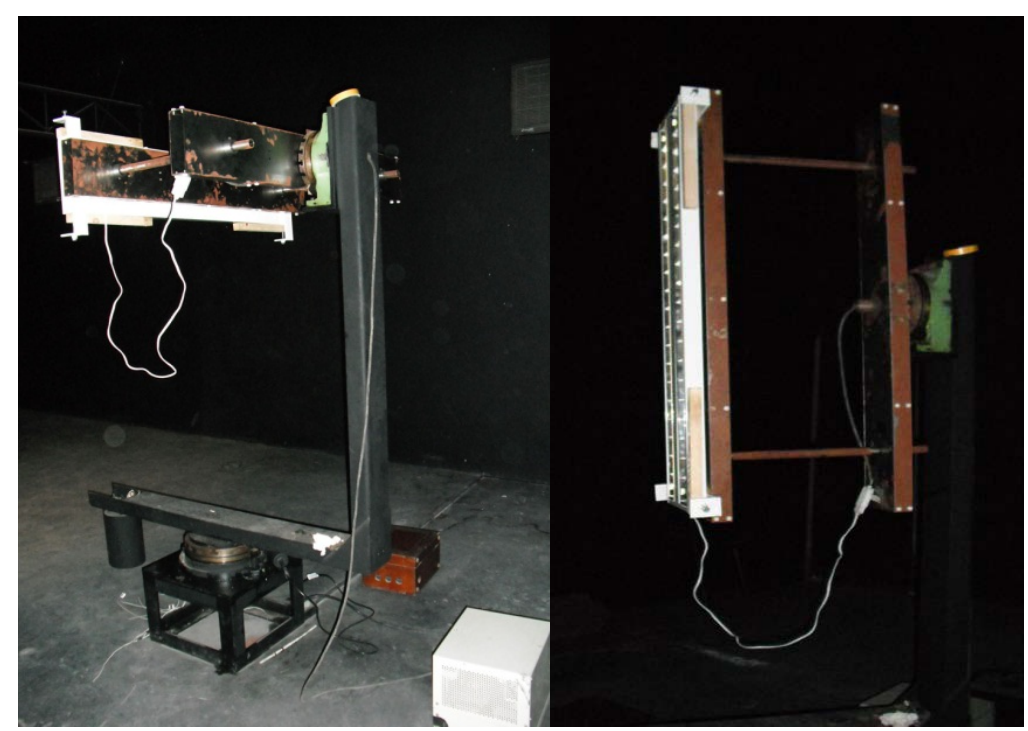

Fonte: Alan Nascimento, 2013.

Figuras 8 e 9 - Goniofotômetro manual, limbos graduados.

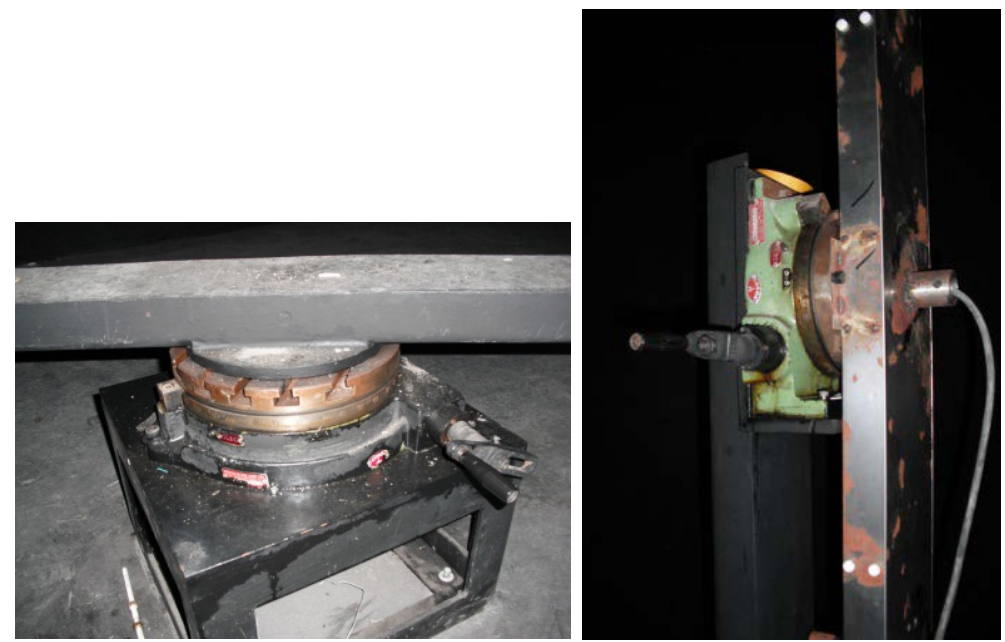

Fonte: Alan Nascimento, 2013. 
Figuras 10 e 11 - Luxímetro MINOLTA posicionado a 6 metros do goniofotômetro.
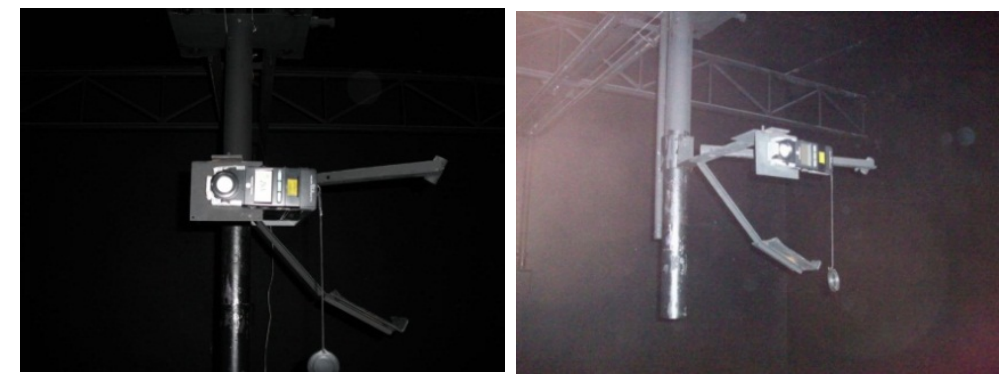

Fonte: Alan Nascimento, 2013.

- Luxímetro - modelo T-10, fabricante MINOLTA, com medições de iluminância de 0.01 até 299,900 Ix. Multifunção de medidor de iluminância digital, comreceptor destacável com fotocélula em silício.

Figura 12 - Luxímetro MINOLTA, modelo T-10.

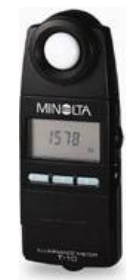

Fonte: MINOLTA, 2011.

- Estabilizador de tensão linear - modelo 1000 TRA-BB/13, fabricante TECTROL.

Potência: 1,0 kVA

Modelo: 1000 TRA-BB/13

Tensões de Entrada e Saída: 110, 127, 220, 380 ou 480 Vca.

Monofásicos ou Trifásicos

Frequência de Entrada-Saída: 50 ou 60 Hz - Senoidal.

Variação da Tensão na Entrada: +/- 15\%.

Regulação de Saída: +/- 1\%

Sistema de Correção Linear por Controle de Ângulo de Fase

Distorção Harmônica: Menor que 5\% 
Figura 13 - Estabilizador de tensão linear, modelo 1000 TRA-BB/13.

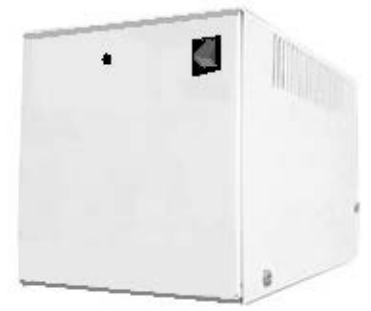

Fonte: TECTROL, 2011.

\subsubsection{Instalações de campo}

$\rightarrow \quad$ Dados da localização das instalações, caracterização e identificação da Instalação 1 :

FASA Fibra Ótica - Av. Marginal FEPASA, 70, Peruíbe, SP, Brasil.

Condição da instalação- Luminárias fixadas por cabos de sustentação em eletrocalhas com plugues macho e fêmea para a conexão elétrica.

Tensão de alimentação da instalação: $220 \mathrm{~V}$.

Altura de instalação: $6,00 \mathrm{~m}$.

Figura 14 - Localização da FASA Fibra Ótica, Peruíbe, SP.

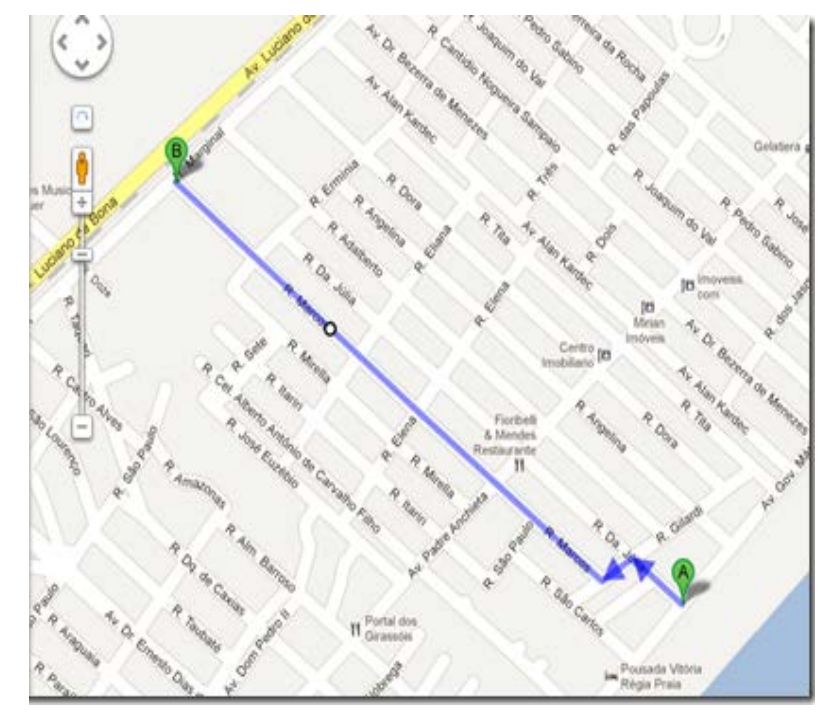

Fonte: http://maps.google.com.br/maps. Acesso em: 1\%/nov/2011 
Figura 15 - Fluxograma da instalação 1 - FASA Fibra Ótica, Peruíbe, SP.

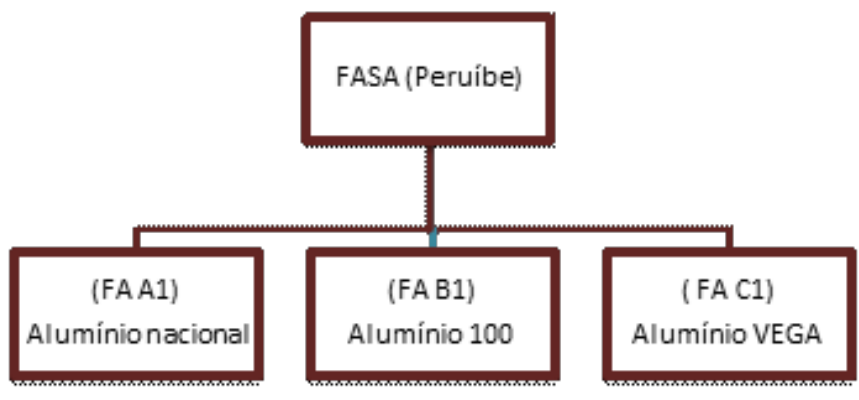

Fonte: a autora,2013.

Tabela 7 - Identificação das luminárias de ensaios - instalação 1- FASA Fibra Ótica, Peruíbe, SP.

\begin{tabular}{|l|c|c|c|c|}
\hline Localização & $\begin{array}{c}\text { Tipo do } \\
\text { Alumínio }\end{array}$ & $\begin{array}{c}\text { Tipo de } \\
\text { Lâmpada }\end{array}$ & Tipo do Reator & Identificação \\
\hline FASA & A 1 & FHT5 2X28W & $\begin{array}{c}\text { QTP5 2X14-35/230-240 } \\
V\end{array}$ & (FA A1) \\
\hline FASA & B 1 & FHT5 2X28W & $\begin{array}{c}\text { QTP5 2X14-35/230-240 } \\
V\end{array}$ & (FA B1) \\
\hline FASA & C 1 & FHT5 2X28W & $\begin{array}{c}\text { QTP5 2X14-35/230-240 } \\
V\end{array}$ & (FA C1) \\
& & & &
\end{tabular}

Fonte: a autora, 2013.

Figura 16 - Identificação das luminárias de ensaios - Instalação 1 - FASA

Fibra Ótica, Peruíbe , SP - Etapas 2 e 3.

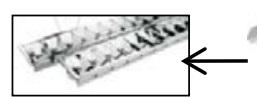

A1

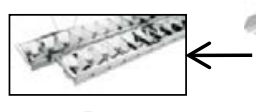

B1

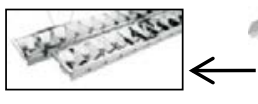

C1

Tipos de alumínios

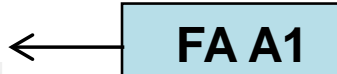

FA A1

\section{$\longleftarrow$ FA B1}

\section{FA C1}


Figuras 17 e 18 - Instalação das luminárias de ensaios FA A1, FA B1, FA C1 na área de montagem da indústria FASA Fibra Ótica, Peruíbe, SP

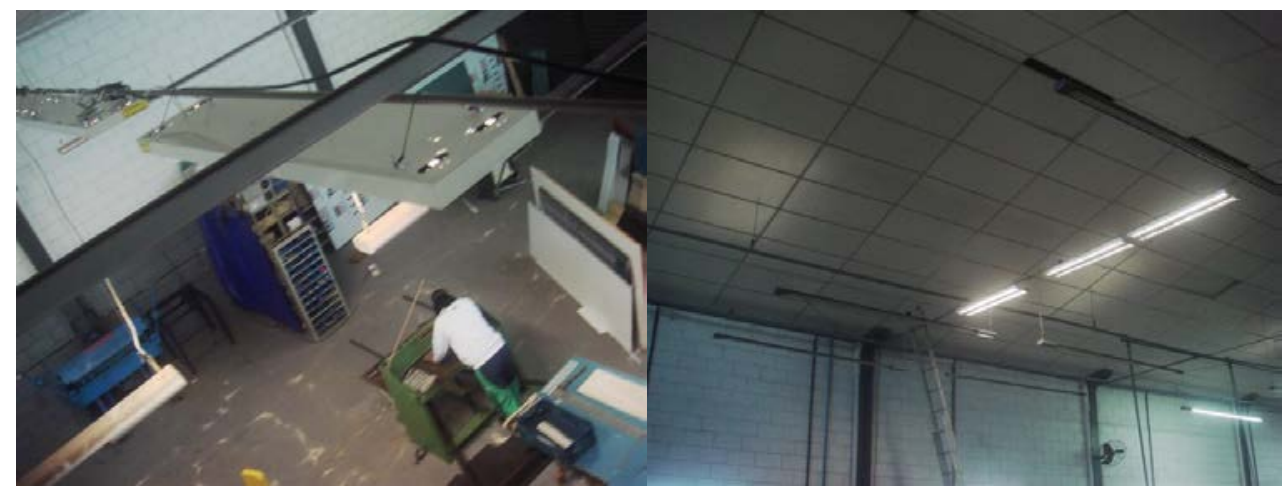

. Fonte: FASA Fibra Ótica, 05/08/2011.

$\rightarrow \quad$ Dados da localização das instalações, caracterização e identificação da Instalação 2 :

LUCCHI Ltda.

Rua Santa Mônica 1.414 - Pq. Industrial San José - Cotia - SP Brasil.

Condição da instalação- Luminárias fixadas por perfil "L" em eletrocalhas por meio de plugues machos e fêmeas para a conexão elétrica.

Tensão de alimentação da instalação: 220V.

Altura de instalação: 3,50 m.

Figura 19- Localização da LUCCHI, Cotia, SP

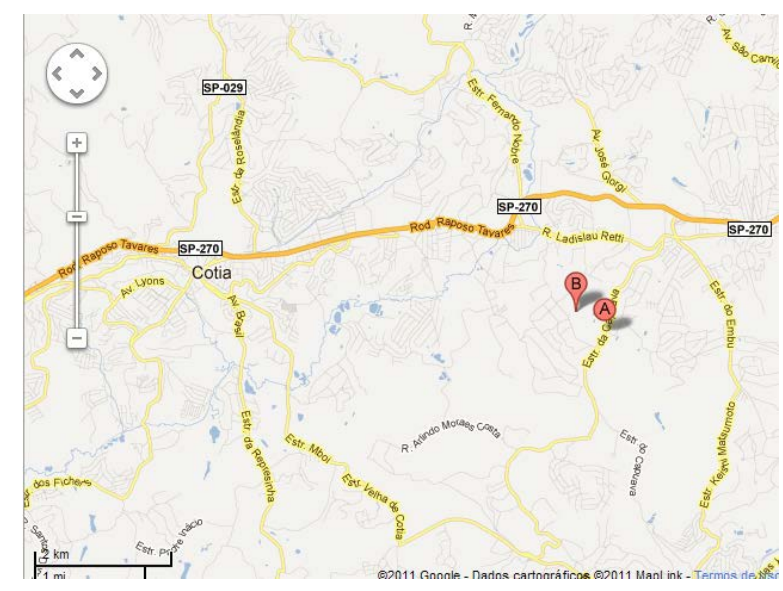

Fonte :http://maps.google.com.br/maps. Acesso em 20/nov/2011. 
Figura 20 - Fluxograma da instalação 2 - LUCCHI, Cotia, SP.

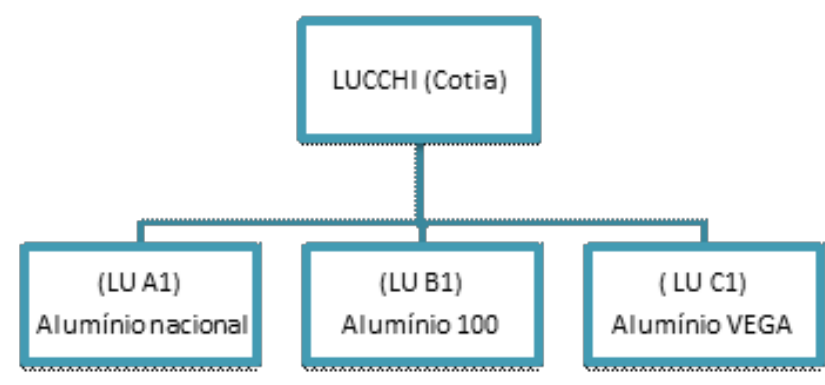

Fonte: a autora, 2013.

Tabela 8: Identificação das luminárias de ensaios- instalação 2- LUCCHI Ltda., Cotia, SP.

\begin{tabular}{|l|c|c|c|c|}
\hline Localização & Tipo do Alumínio & Tipo de Lâmpada & Tipo do Reator & Identificação \\
\hline LUCCHI & A 1 & FHT5 2X28W & QTP5 2X14-35/230-240 V & (LU A1) \\
\hline LUCCHI & B 1 & FHT5 2X28W & QTP5 2X14-35/230-240 V & (LU B1) \\
\hline LUCCHI & C 1 & FHT5 2X28W & QTP5 2X14-35/230-240 V & (LU C1) \\
\hline
\end{tabular}

Fonte: a autora, 2013.

Figura 21 - Identificação das luminárias de ensaios - Instalação 2 - LUCCHI, Cotia, SP - Etapas 2 e 3.

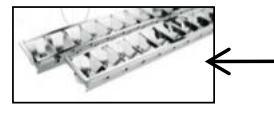

A1

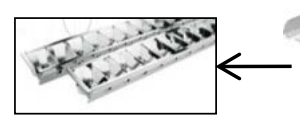

B1

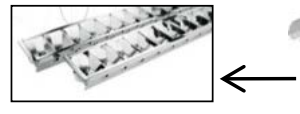

C1

Tipos de alumínios
II- in

$\neq$
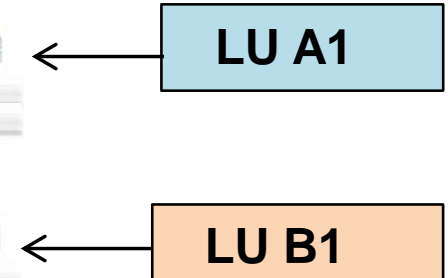

$=$

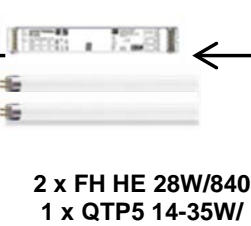
230-240V

Fonte: a autora, 2013. 
Figuras 22 e 23 - Instalação das luminárias de ensaios LU A1, LU B1, LU C1 na área de armazenagem no centro de distribuição da LUCCHI Ltda, Cotia, SP.

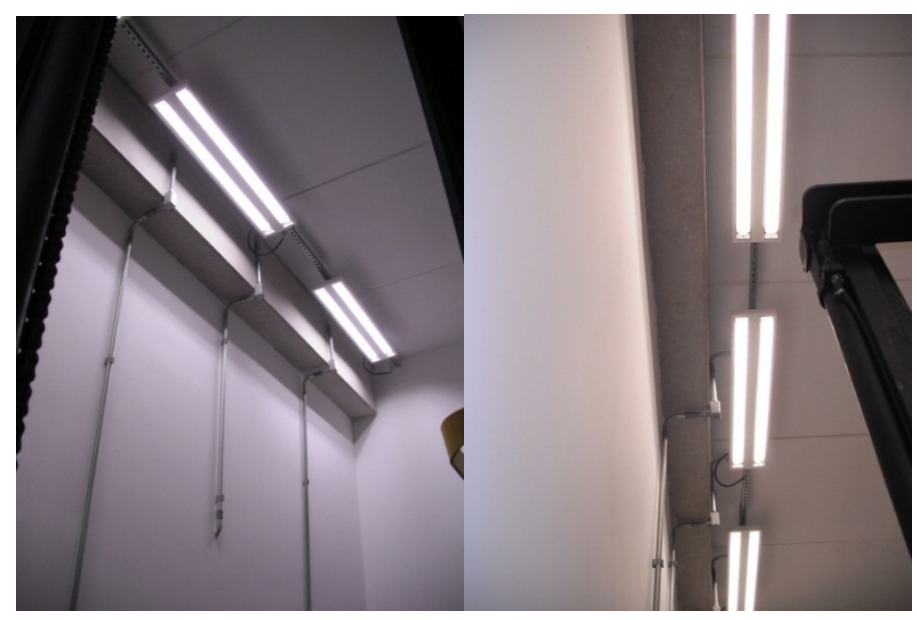

Fonte: autora, 26/07/2011.

$\rightarrow \quad$ Dados da localização das instalações, caracterização e identificação da Instalação 3 :

Condomínio PORTO DE IBIÚNA, Rodovia SP 250, Ibiúna, SP, Brasil. Característica da instalação - Condomínio residencial a 8.000 m da Rodovia Bunjiro Nakao - SP 250, no interior de São Paulo.

Condições da instalação - Luminárias fixadas por meio de parafusos na viga de madeira da estrutura do telhado ou através de perfis metálicos.

Tensão de alimentação da instalação: $127 \mathrm{~V}$ (para essa instalação foi necessário a troca dos reatores eletrônicos modelo QUICKTRONIC QTP5 2x14-35/230-240V por reatores eletrônicos Modelo EL214-28A26 100 -245 V, PHILIPS $^{12}$.

Altura de instalação: 2,70 m (sala de reunião e sala da gerência e recepção) e 3,50 m (sala da administração).

\footnotetext{
${ }^{12}$ No Condomínio PORTO DE IBIÚNA a tensão de rede é 120-130V. Houve troca do padrão do reator eletrônico para o modelo da PHILIPS EL214-28A26 100-245 V. Este fato não alterou as informações e ensaios, já que as medições fotométricas foram executadas com as lâmpadas fluorescentes tubulares consideradas neste trabalho como de referência padrão secundário FL028/FL028A, e com o reator eletrônico de referência padrão secundário RE028.
} 
Figura 24 - Localização da instalação 3 do Condomínio PORTO de IBIÚNA, Ibiúna, SP.

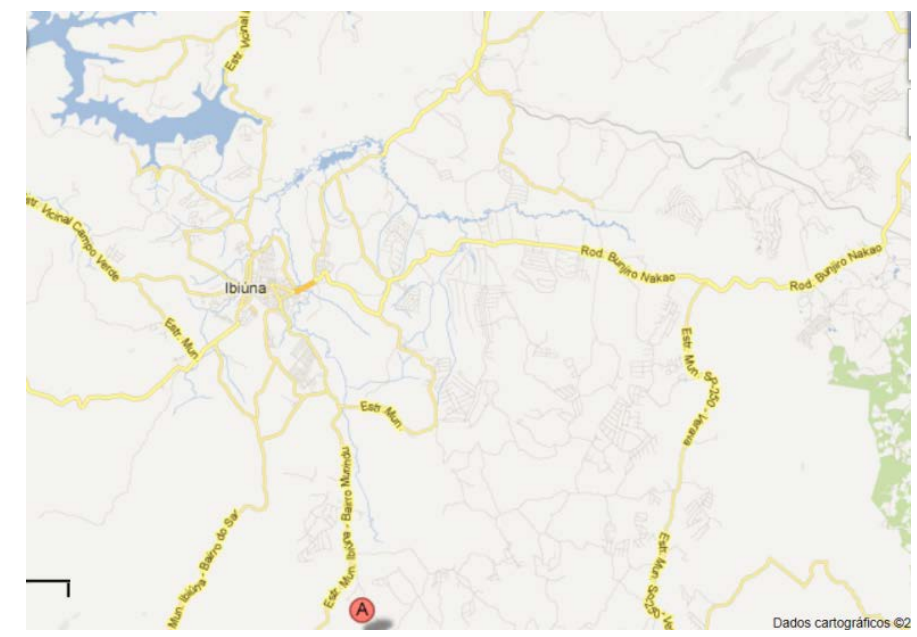

Fonte: https://maps.google.com.br/maps. Acesso em 03/fev/13.

Figura 25 - Fluxograma instalação 3 - Condomínio PORTO de IBIÚNA, Ibiuna, SP.

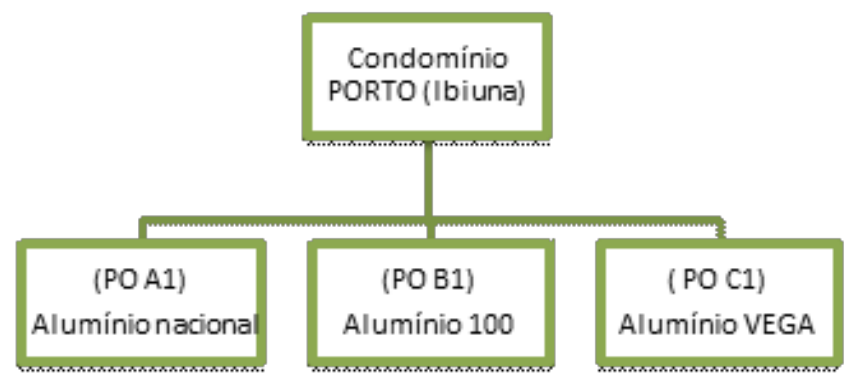

Fonte: a autora, 2013.

Tabela 9 - Identificação das luminárias de ensaios- Instalação 3 - no Condomínio PORTO de IBIÚNA, Ibiúna, SP.

\begin{tabular}{|l|c|c|c|c|}
\hline Localização & $\begin{array}{c}\text { Tipo do } \\
\text { Alumínio }\end{array}$ & $\begin{array}{c}\text { Tipo de } \\
\text { Lâmpada }\end{array}$ & Tipo do Reator & Identificação \\
\hline PORTO IBIÚNA & A 1 & FHT5 2X28W & EL214-28A26 100-245 V & (PO A1) \\
\hline PORTO IBIÚNA & B 1 & FHT5 2X28W & EL214-28A26 100-245 V & (PO B1) \\
\hline PORTO IBIÚNA & C 1 & FHT5 2X28W & EL214-28A26 100-245 V & (PO C1) \\
\hline
\end{tabular}

Fonte: a autora, 2013. 
Figura 26 - Identificação das luminárias de ensaios - Instalação 3 Condomínio PORTO de IBIÙNA, Ibiúna, SP - Etapas 2 e 3.

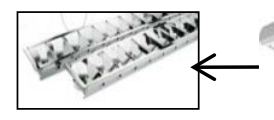

A1

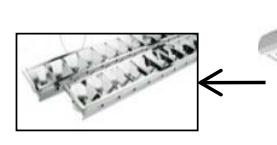

B1

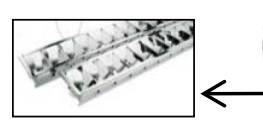

C1

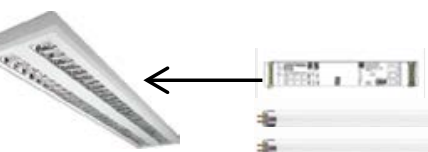

$\neq$

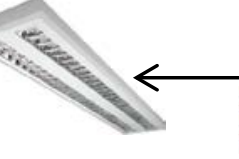

Fin, i I I

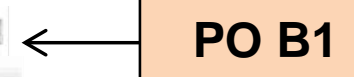

Tipos de alumínios

Luminárias CS-656

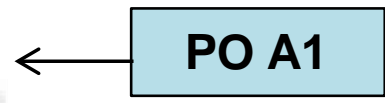

\section{PO B1}

PO C1

Fonte: a autora, 2013.

Figuras 27, 28 e 29 - Instalação das luminárias de ensaios PO A1 (sala de reunião), PO B1 (sala administração) e PO C1 (sala da gerência e recepção) Condomínio PORTO de IBIÚNA, Ibiúna, SP.

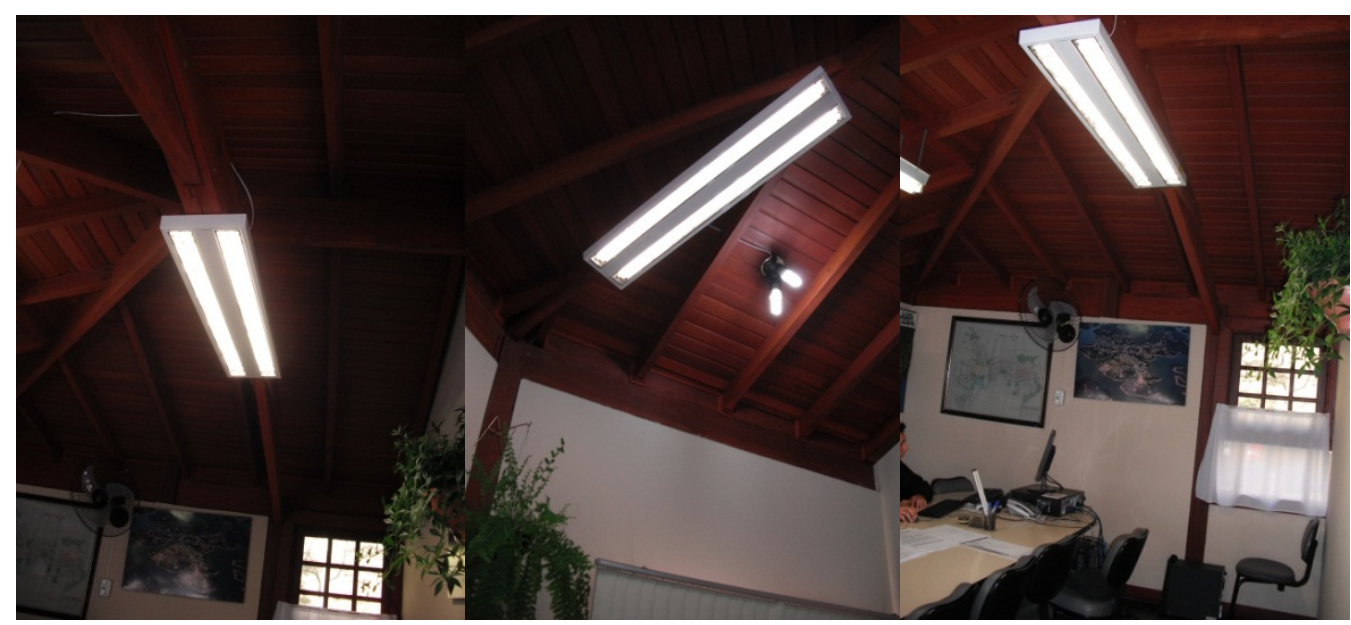

Fonte: a autora, 2013.

\subsubsection{Condições dos ensaios e procedimentos em campo e laboratório}

Para a obtenção dos dados para analise e comparação dos sistemas óticos, foram consideradas no levantamento em laboratório três etapas, 
descritas no item 2.5 e no levantamento em campo dois a três períodos para efeito de analise das perdas luminosas.

Tabela 10: Registro das datas das instalações, retiradas e períodos de funcionamento dos sistemas.

\begin{tabular}{|c|c|c|c|c|c|c|c|c|c|c|c|c|c|c|c|c|c|c|}
\hline \multirow{2}{*}{ Instalação / Tempo } & \multicolumn{6}{|c|}{2011} & \multicolumn{12}{|c|}{2012} \\
\hline & JUL & AGO & SET & OUT & NOV & DEZ & JAN & FEV & MAR & ABR & MAI & JUN & JUL & AGO & SET & OUT & NOV & DEZ \\
\hline \multirow[t]{6}{*}{ Instalação 1 -FASA } & & $4 / 8$ & & & & & $9 / 1$ & & & & & & & & & & & \\
\hline & & \multicolumn{6}{|c|}{816 horas } & & & & & & & & & & & \\
\hline & & & & & & & $29 / 1$ & & & & $30 / 5$ & & & & & & & \\
\hline & & & & & & & \multicolumn{5}{|c|}{696 horas } & & & & & & & \\
\hline & & & & & & & & & & & & $6 / 6$ & & & & & & $19 / 12$ \\
\hline & & & & & & & & & & & & & & & 28 ho & & & \\
\hline \multirow[t]{4}{*}{ Instalação 2- LUCCHI } & $26 / 7$ & & & & & & & & & & $23 / 5$ & & & & & & & \\
\hline & \multicolumn{11}{|c|}{1.576 horas } & & & & & & & \\
\hline & & & & & & & & & & & & $5 / 6$ & & & & & & $19 / 12$ \\
\hline & & & & & & & & & & & & \multicolumn{7}{|c|}{1.140 horas } \\
\hline \multirow[t]{4}{*}{ Instalação 3- PORTO de IBIÚNA } & & $2 / 8$ & & & & & & & & & $31 / 5$ & & & & & & & \\
\hline & & \multicolumn{10}{|c|}{1.648 horas } & & & & & & & \\
\hline & & & & & & & & & & & & $5 / 6$ & & & & & & $22 / 12$ \\
\hline & & & & & & & & & & & & \multicolumn{7}{|c|}{208 horas } \\
\hline
\end{tabular}

\begin{tabular}{|l|l|}
\hline Instalação 1 & 2.640 horas \\
\hline Instalação 2 & 2.720 horas \\
\hline Instalação 3 & 2.856 horas \\
\hline
\end{tabular}

- As "luminárias de ensaios" foram instaladas nos meses de julho e agosto de 2011 nas três localidades, conforme Tabela 10, por um primeiro período médio de $1.500 \mathrm{~h}$ e, posteriormente, por mais um período médio de $1.150 \mathrm{~h}$, totalizando 18 meses, e um período mínimo de $2.640 \mathrm{~h}$ e máximo de $2.856 \mathrm{~h}$, definidas no item 2.5.

- No intervalo de cada período da Etapa 1 e Etapa 2, as "luminárias de ensaios" foram retiradas das instalações e encaminhadas para o Laboratório de Fotometria da empresa Carolino Indústria e Comércio Ltda., para o levantamento das suas características fotométricas e a identificação das intensidades luminosas (cd) com medições nos planos transversais e longitudinais.

- O levantamento em laboratório determinou as iluminâncias (Ix) nos ângulos de $0^{\circ}, 5^{\circ}, 10^{\circ}, 15^{\circ}, 20^{\circ}, 25^{\circ}, 30^{\circ}, 35^{\circ}, 40^{\circ}, 45^{\circ}, 50^{\circ}, 55^{\circ}, 60^{\circ}, 65^{\circ}$, $70^{\circ}, 75^{\circ}, 80^{\circ}, 85^{\circ}$ e $90^{\circ}$, em ambos os eixos dos planos, e as intensidades luminosas (cd) foram obtidas nas direções consideradas, por meio da lei de Lambert, conforme tabulação utilizada no item 2.5.4.

- Levantamento dos rendimentos de cada modelo, conforme os dados extraídos na planilha de medições em laboratório. Medimos as 
iluminâncias que após método matemático se transformam nos rendimentos, conforme item 2.5.4.

- Elaboração de curvas de distribuição luminosas (CDL) de cada modelo ensaiado.

- Para as medições fotométricas foram retiradas as lâmpadas fluorescentes tubulares de mercado T5 HE FH $28 \mathrm{~W} / 840$ e os reatores eletrônicos QUICKTRONIC QTP 5 14-35W/230-240V, e substituídas pelas lâmpadas de referência padrão secundário FL028 e FL028A e pelo reator eletrônico de referência padrão secundário RE028, já que não existe interesse na depreciação dos equipamentos, mas somente o de analisar as perdas luminosas procedentes dos alumínios por meio dos conjuntos óticos .

- Através da metodologia proposta foi possível determinar os desempenhos fotométricos dos refletores óticos em cada instalação, após os períodos de uso.

- Foi realizada a comparação dos três diferentes refletores óticos, considerando que os "conjuntos de referências" serviram como um padrão, sem nenhum tipo de depreciação;

- Com os resultados obtidos foi possível conhecer a influência das características óticas dos refletores de alumínio dos conjuntos óticos e suas perdas luminosas.

\subsubsection{Método para determinação dos rendimentos dos sistemas óticos}

Para obtenção dos dados em laboratório, usou-se como referência métodos extraídos do IESNA e do CIE que estabelecem um sistema de levantamento de planos para fotometria de luminárias para interiores. Utilizou-se de uma planilha com o lançamento das medições fotométricas, conforme tabela 11. Para obtenção do rendimento, temos o fluxo total da fonte multiplicando pelas intensidades luminosas média de cada zona pela constante zonal. Com a somatória dos valores obtidos temos os fluxos totais que dividimos pelos fluxos luminosos das duas lâmpadas fluorescentes tubulares FL028/FL028A, neste caso, total de $5.800 \mathrm{Im}$. 
A constante zonal é igual a $K=2 \pi\left(\cos \theta_{1}-\cos \theta_{2}\right)$. Os valores podem ser tabelados para diversos intervalos. Na tabela 11, temos a tabulação das constantes zonais para intervalos de $10^{\circ}$ (MOREIRA, 2006), utilizada em nossa planilha, conforme tabela 12.

Tabela 11 - Constantes zonais para intervalos de $10^{\circ}$.

\begin{tabular}{|c|c|c|c|c|}
\hline \multicolumn{9}{|c|}{ Para intervalos de $10^{\circ}$} \\
\hline$\theta_{2}$ & $\theta_{1}$ & $\theta_{2}$ & $\theta_{1}$ & $\mathrm{~K}=2 \pi\left(\cos \theta_{1}-\cos \theta_{2}\right)$ \\
\hline 10 & 0 & 180 & 170 & 0,0955 \\
\hline 20 & 10 & 170 & 160 & 0,2835 \\
\hline 30 & 20 & 160 & 150 & 0,4629 \\
\hline 40 & 30 & 150 & 140 & 0,6282 \\
\hline 50 & 40 & 140 & 130 & 0,7744 \\
\hline 60 & 50 & 130 & 120 & 0,8976 \\
\hline 70 & 60 & 120 & 110 & 0,9926 \\
\hline 80 & 70 & 110 & 100 & 1,0579 \\
\hline 90 & 80 & 100 & 90 & 1,0911 \\
\hline
\end{tabular}

Fonte: MOREIRA, 2006.

Tabela 12 - Planilha padrão para tabulação das iluminâncias, intensidades luminosas e rendimentos no plano transversal e longitudinal.

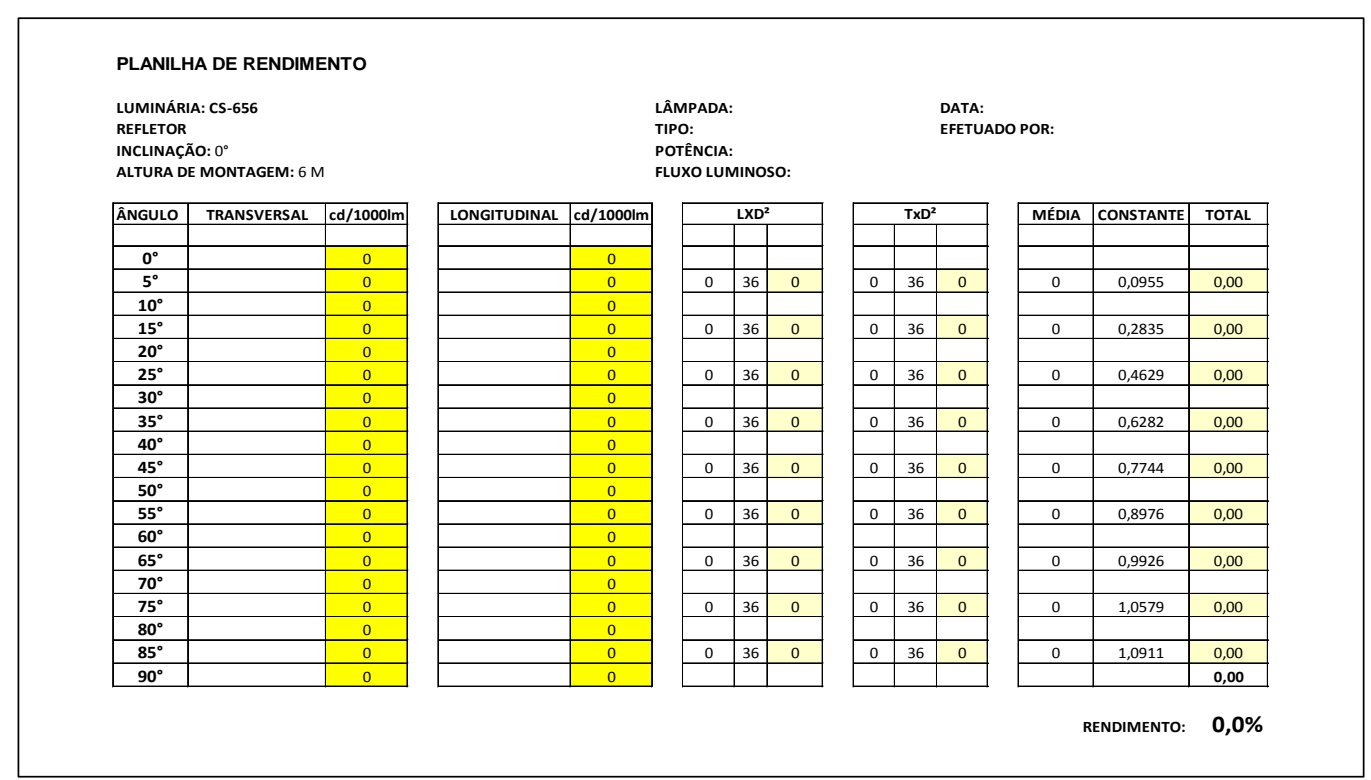

Fonte: Aguinaldo dos Reis, Carolino Indústria e Comércio Ltda., 2011. 
3 DADOS SECUNDARIOS: ASPECTOS NORMATIVOS, CERTIFICACÕES E REGULARMENTACO̊ES

\subsection{Introdução}

A Associação Brasileira de Normas Técnicas (ABNT), fundada em 1940, é o órgão nacional responsável pela normalização técnica para o fornecimento da base necessária ao desenvolvimento tecnológico brasileiro. É membro fundador da ISO (International Organization for Standardization), da COPANT (Comissão Panamericana de Normas Técnicas) e da AMN (Associação Mercosul de Normalização). É também a única e exclusiva representante no Brasil das seguintes entidades internacionais: ISSO, IEC (International Electrotechnical Commission) e das entidades de normalização regionais COPANT e AMN. O órgão internacional mais significativo relacionado à aplicação de iluminação é o CIE (Commission Internationale de l'Éclairage), uma organização dedicada a promover a troca de informações, entre seus países membros, sobre assuntos relevantes na área da iluminação, servindo inclusive como base para as recomendações utilizadas no Brasil.

\subsection{Normas Brasileiras Regulamentadoras (NBRs)}

No Brasil existem normas regulamentadoras NBR que relacionam diretamente os produtos utilizados no mercado com o projeto de iluminação:

\subsubsection{ABNT NBR 5461/1991 - lluminação (terminologia)}

Esta Norma define termos técnicos empregados para fenômenos produzidos ou associados às radiações eletromagnéticas, visão de objetos e cenas iluminadas, fotometria e colorimetria, produção e utilização prática da luz e ótica energética. É uma norma que visa somente esclarecer a terminologia utilizada nas normas subsequentes. 


\subsubsection{ABNT NBR 5413:1992 - Iluminação de interiores}

Esta Norma estabelece os valores de iluminâncias médias mínimas em serviço para iluminação artificial em interiores, onde se realizem atividades de comércio, indústria, ensino, esporte e outras atividades, e estão subdivididos em diversas áreas (com diferentes tipos de uso), de acordo com a tarefa a ser executada. Os níveis de iluminância estão expressos em lux. Para aplicação da Norma ABNT NBR 5413/1992, é necessária consulta às Normas ABNT NBR 5382/1985 e ABNT NBR 5461/1991.

A Norma estabelece que a iluminância deva ser medida no campo de trabalho e, quando este não for definido, entende-se como tal o nível referente a um plano horizontal a $0,75 \mathrm{~m}$ do piso. A iluminância deve garantir no restante do ambiente que não seja inferior a 1/10 da adotada para o campo de trabalho, mesmo que haja recomendação para valor menor, e que qualquer ponto do plano de trabalho não seja inferior a $70 \%$ da iluminância média determinada segundo a ABNT NBR 5382/1985. As iluminâncias são determinadas por classe de tarefas visuais, considerando três fatores determinantes, como a idade dos usuários, velocidade e precisão da execução das tarefas e a refletância do fundo da tarefa.

\subsubsection{ABNT 5382/1985 - Verificação da lluminância de interiores- Método de ensaios}

Esta Norma fixa o modo pelo qual se faz a verificação da iluminância de interiores de áreas retangulares, através da iluminância média sobre um plano horizontal, proveniente da iluminação geral.

\subsubsection{ABNT NBR ISO 8995-1- Iluminação de ambientes de trabalho (norma aprovada em fase de publicação pela ABNT).}

Esta Norma substituirá as ABNT NBR 5413/1992 e ABNT NBR 5382/1985 e, diferentemente dos critérios básicos adotados por ambas, esta versão incorporará outros parâmetros e requisitos de iluminação para locais de trabalho internos, para que as pessoas desempenhem tarefas visuais de 
maneira eficiente, com conforto e segurança durante todo o período de trabalho.

Todos os valores de iluminâncias especificados nesta Norma serão de iluminâncias mantidas (lux), valor que a luminância média da superfície especificada não poderá ser reduzida, independentemente da idade das pessoas e das condições da instalação. O projetista deverá considerar para o projeto fatores de depreciação adequados para cada tipo de instalação proposta. A iluminância mantida passará a ser considerada na área de tarefa e do entorno imediato (zona de, no mínimo, 0,5 m de largura ao redor da área de tarefa dentro do campo de visão), devendo prover uma distribuição bem balanceada da luminância nesta condição.

Outro critério a ser introduzido é o do ofuscamento desconfortável, que será determinado pelo método tabular do Índice de Ofuscamento Unificado da CIE (UGR), baseado na posição padrão do observador e com razão de 1:1 da relação entre espaçamento e altura dos sistemas de iluminação. Se a instalação da iluminação for composta por tipos diversos de luminárias com diferentes fotometrias e/ou lâmpadas, a determinação do valor UGR deverá ser aplicada para cada combinação lâmpada/ luminária da instalação. Desta maneira, o maior valor do UGR encontrado deverá ser considerado como um valor típico para a instalação inteira e estar em conformidade com o UGR limite.

Deverá ser introduzido um índice geral de reprodução de cor $\mathrm{Ra}, \mathrm{a}$ fim de propiciar uma indicação objetiva das propriedades de reprodução de cor referente a uma fonte luminosa. Já para fornecer uma indicação objetiva das propriedades de reprodução de cor de uma fonte de luz, será inserido o índice geral de reprodução de cor Ra. O valor máximo de Ra é 100. Este valor diminui com a redução da qualidade de reprodução de cor. Em interiores onde as pessoas trabalham ou permanecem por longos períodos, a Norma não recomendará a utilização de lâmpadas com Ra inferior a 80. 


\subsubsection{ABNT NBR IEC 60598-1/2010 - Luminárias - Parte 1: Requisitos gerais e ensaios}

Esta Parte 1 da ABNT NBR IEC 60598 especifica os requisitos gerais para luminárias, incorporando fontes elétricas de luz com tensões de alimentação não superiores a 1.000 V. Os requisitos e ensaios correspondentes desta Norma abrangem classificação, marcação, construção mecânica e construção elétrica, juntamente com os ensaios correspondentes

Chama-se atenção para o fato de que a Parte 1 da Norma abrange todos os aspectos relativos à segurança (elétrica térmica e mecânica). As luminárias devem ser projetadas e construídas de modo que, em utilização normal, sua operação seja segura e não cause perigo às pessoas e ao ambiente próximo.

Em geral, a conformidade é verificada com a realização de ensaios especificados. O Anexo $L$ da Norma é um guia de boa prática para o projeto de luminárias e tem como objetivo apresentar recomendações aos fabricantes sobre os aspectos do projeto das luminárias que, devido sua natureza, não são atualmente controladas por ensaios normalizados e regimes de verificação. O anexo fornece informação cobrindo aspectos como seleção de materiais, degradação do material plástico durante a vida, efeitos de elementos corrosivos e proteção apropriada, considerações térmicas no projeto óptico, recomendações relacionados com o fenômeno do fim de vida de lâmpadas e resistência contra vibração.

\subsubsection{ABNT NBR IEC 60598-2-1/2012 - Luminárias - Parte 2: Requisitos particulares- Capítulo 1: Luminárias fixas para uso geral em iluminação geral}

Esta seção da Parte 2 da ABNT NBR IEC 60598 especifica os requisitos para as luminárias fixas no uso geral para utilização com lâmpadas de filamento de tungstênio, lâmpadas tubulares fluorescentes e com outras lâmpadas de descarga nas tensões de alimentação que não excedam 1.000 
V. Onde existir uma referência, esta parte é para ser lida em conjunto com as outras seções da Parte 1.

\subsection{Certificações de Edifícios Sustentáveis}

Existem diversos sistemas de Certificação de Edifícios Sustentáveis. No Brasil estão em uso o LEED, do USGBC (United States Green Building Council), de origem norte-americana, e o AQUA (Alta Qualidade Ambiental), baseado no HQE (Haute Qualité Environnemetale), de origem francesa. Estes sistemas não certificam materiais e produtos, apenas edifícios.

\subsubsection{Certificação LEED}

O LEED (Leadership in Energy and Environmental Design) é um sistema de certificação e orientação ambiental de edificações, criado pelo USGBC. Trata-se do selo de maior reconhecimento internacional e o mais utilizado em todo o mundo, inclusive no Brasil.

Em março de 2007, foi criado o GBCB - Green Building Council Brasil, organização não governamental criada para auxiliar no desenvolvimento da indústria da construção sustentável no País, utilizando as forças de mercado para conduzir a adoção de práticas de Green Building em um processo integrado de concepção, construção e operação de edificações e espaços construídos.

O GBC Brasil é um dos 21 membros do World Green Building Council, entidade supranacional que regula e incentiva a criação de Conselhos Nacionais como forma de promover mundialmente tecnologias, iniciativas e operações sustentáveis na construção civil. No Brasil, atualmente, é o quarto no ranking mundial de construções verdes com 51 prédios certificados e 525 em processo de certificação, atrás apenas dos EUA, Emirados Árabes Unidos e China. Até o momento, a certificação LEED no país segue as mesmas diretrizes do LEED americano, mas está em andamento um projeto especifico desse sistema de certificação para o Brasil.

O LEED oferece quatro níveis de certificação, que dependem da pontuação obtida na fase de concepção: Certificado - Certificação Básica (26 
a 32 pontos), Prata (33 a 38 pontos), Ouro (39 a 51 pontos) e Platina (52 a 69 pontos).

As principais categorias avaliadas são:

Espaço sustentável (Sustainable Sites - SS) - Critério que sugere a redução da poluição luminosa noturna;

Energia e atmosfera (Energy \& Atmosphere - EA) - Critério que leva em consideração o desempenho energético eficiente e o consumo mínimo de energia, conforme norma ANSI/ASHRAE/IESNA Standard 90.1-2007; e

Qualidade ambiental interna (Indoor Environmental Quality - EQ) Considerações em relação ao controle da iluminação artificial;

As tipologias dos empreendimentos LEED são: novas construções e grandes projetos de renovação, desenvolvimento de bairro (localidades), projetos da envoltória e parte central do edifício, lojas de varejo, unidades de saúde, operação de manutenção de edifícios existentes, edifícios escolares, projetos de interiores e edifícios comerciais.

\subsubsection{Certificação AQUA}

A certificação AQUA teve início em 2007 e é concedida pela Fundação Vanzolini. O seu referencial técnico foi baseado no HQE, da França.

O AQUA é o primeiro selo que levou em conta as especificidades do Brasil para elaborar seus 14 critérios. Estes avaliam a gestão ambiental das obras e as especificidades técnicas e arquitetônicas, considerando a relação do edifício com o seu entorno; escolha integrada de produtos; sistemas e processos construtivos e canteiro de obras com baixo impacto ambiental; a gestão de energia, da água, dos resíduos de uso e operação do edifício; manutenção, permanência do desempenho ambiental; conforto térmico, acústico, visual; e qualidade sanitária dos ambientes, do ar e da água.

O processo visa garantir a qualidade ambiental de um empreendimento novo de construção ou reabilitação, fazendo uso de auditorias independentes. Segundo a Fundação Vanzolini, ele pode ser definido "como sendo um processo de gestão de projeto visando obter a qualidade ambiental de um empreendimento novo ou envolvendo uma 
reabilitação". Os benefícios da certificação pelo Processo AQUA incluem melhorias que atingem o empreendedor, comprador e a questão socioambiental.

O referencial técnico de certificação do processo AQUA estrutura-se em dois elementos:

- SGE (Sistema de Gestão do Empreendimento) - avalia o sistema de gestão ambiental implantado.

- QAE (Qualidade Ambiental do Edificio) - avalia o desempenho arquitetônico e técnico do edifício.

Esta estrutura utilizada permite que haja a organização necessária para se atingir a qualidade ambiental desejada. O SGE define a qualidade ambiental, organiza e controla os processos operacionais em todas as fases do programa, passando pela concepção (projeto), realização (obra) e operação ou uso (Fundação Vanzolini, 2011).

A certificação é concebida segundo classificação em três níveis: "Bom" (práticas correntes, legislação), "Superior" (boas práticas) e "Excelente" (melhores práticas). Para obtenção da certificação é exigido um número mínimo de classificação "Excelente" e um número máximo da classificação "Bom". Uma peculiaridade do sistema é que o padrão mínimo de exigência remete ao que está normatizado e regulamentado.

As principais tipologias dos empreendimentos AQUA são escritórios, edifícios escolares, hotéis e edifícios habitacionais.

\subsection{Regulamentações}

\subsubsection{Procel Edifica: Plano de ação para eficiência energética em edificações}

O Procel Edifica é o plano de ação para eficiência energética em edificações, e visa construir as bases necessárias para racionalizar o consumo de energia nas edificações no Brasil. Em 2005, o Inmetro - Instituto Nacional de Metrologia, Qualidade e Tecnologia foi incluído no processo, através da criação da CT Edificações, a Comissão Técnica, na qual é 
discutido e definido o processo de obtenção da Etiqueta Nacional de Conservação de Energia (ENCE).

A etiquetagem e a inspeção foram definidas como mecanismos de avaliação da conformidade para classificação do nível de eficiência energética de edifícios. Isto ocorre após um processo que teve inicio em 2001, com a promulgação da Lei $n^{\circ} 10.295$, que dispõe sobre a Política Nacional de Conservação e Uso Racional de Energia (BRASIL, 2001a). Em seguida, o Decreto n 4059, de 19 de dezembro de 2001 (BRASIL, 2001b), regulamentou a lei estabelecendo "níveis máximos de consumo de energia, ou mínimos de eficiência energética, de máquinas e aparelhos consumidores de energia fabricados ou comercializados no País, bem como as edificações construídas". Apontou também a necessidade de "indicadores técnicos e regulamentação específica" para níveis de eficiência energética no Brasil.

Em uma de suas vertentes de ação - Subsídios à Regulamentação são determinados os parâmetros referenciais para verificação do nível de eficiência energética de edificações.

Nesta vertente, foi desenvolvido o Regulamento Técnico da Qualidade do Nível de Eficiência Energética de Edifícios Comerciais, de Serviços e Públicos (RTQ-C) e seus documentos complementares, como o Regulamento de Avaliação da Conformidade do Nível de Eficiência Energética de Edifícios Comerciais, de Serviços e Públicos (RAC-C), ambos publicados pelo Inmetro, e o Manual para Aplicação do RTQ-C.

\subsubsection{Regulamento Técnico da Qualidade do Nível de Eficiência Energética de Edifícios Comerciais, de Serviços e Públicos (RTQ-C)}

Conforme relatório técnico do método de avaliação do Sistema de Iluminação do RTQ-C, elaborado pelo Laboratório de Eficiência Energética em Edificações, da Universidade Federal de Santa Catarina (UFSC), com o apoio de outras instituições como a Universidade Federal de Minas Gerais (UFMG) e a Universidade Nacional de Brasilia (UNB), o Regulamento Técnico da Qualidade do Nível de Eficiência Energética de Edifícios Comerciais, de Serviços e Públicos (RTQ-C) teve sua primeira versão regulamentada pela Portaria Inmetro n. $^{\circ}$ 53, de 27 de fevereiro de 2009, 
posteriormente sucedida pela Portaria Inmetro n. ${ }^{\circ} 163$, de 08 de junho de 2009. Nela são especificados os requisitos técnicos e os métodos para classificação de edifícios comerciais, de serviços e públicos quanto à eficiência energética, criando condições para a etiquetagem do nível de eficiência energética desta tipologia de edifícios. Três requisitos principais são avaliados: a envoltória do edifício, o sistema de iluminação e o sistema de condicionamento do ar.

Após o primeiro ano de aplicação do RTQ-C, a realização de dois cursos sobre a avaliação pelo método prescritivo proposto pelo Regulamento, a análise de dúvidas enviadas pelos usuários, a resposta do mercado e a realização de um seminário pelo Conselho Brasileiro de Construção Sustentável (CBCS) envolvendo fornecedores e projetistas do sistema de iluminação, verificou-se a necessidade de revisão em alguns pontos do RTQ-C. O método proposto para avaliação do sistema de iluminação apresentou algumas limitações, tendo em vista a prática projetual do mercado e a grande quantidade de informações requeridas, nem sempre possíveis de serem obtidas.

Diante desta questão, foi proposta a alteração do método de avaliação desse sistema, baseando-o no método de avaliação utilizado pela American Society of Heating, Refrigerating, and Air-Conditioning Engineers ASHRAE 90.1, norma já consolidada no Brasil para o mercado de prédios verdes. Este novo método determina a densidade de potência máxima instalada por atividade ou uso da edificação (W/m2), o que permite a determinação de limites para carga instalada de acordo com a atividade. Além disso, favorece a redução da possibilidade de superdimensionamento do sistema e conduz a uma avaliação mais rápida por parte do laboratório de inspeção.

A etiquetagem do edifício é voluntária e aplicável a edifícios com área útil superior a $500 \mathrm{~m}^{2}$ ou atendidos por alta tensão (grupo tarifário A). Pode ser fornecida uma etiqueta para o edifício completo ou para parte deste. Ela é dita parcial quando referente à envoltória ou combinando a envoltória com um dos outros dois sistemas - iluminação ou condicionamento de ar. 
O RTQ-C apresenta os critérios para classificação completa do nível de eficiência energética do edifício, através de classificações parciais da envoltória, do sistema de iluminação e do sistema de condicionamento de ar. Uma equação pondera estes sistemas por meio de pesos estabelecidos no Regulamento e permite somar à pontuação final bonificações que podem ser adquiridas com inovações tecnológicas, uso de energias renováveis, cogeração ou com a racionalização no consumo de água.

As exigências contidas no RTQ-C devem ser avaliadas por um laboratório de inspeção designado ou acreditado pelo Inmetro, de forma que este verifique as características projetadas e construídas do edifício e indicar qual o nível de eficiência alcançado por este. Este é o conteúdo do RAC-C, onde duas etapas de avaliação, de projeto e do edifício construído, compõem o processo.

\subsubsection{Regulamento de Avaliação da Conformidade do Nível de Eficiência Energética de Edifícios Comerciais, de Serviços e Públicos (RAC-C)}

O RAC-C apresenta o processo de avaliação das características do edifício para etiquetagem junto ao laboratório de inspeção acreditado pelo Inmetro. É o documento que permite ao edifício obter a Etiqueta Nacional de Conservação de Energia (ENCE), pelo Inmetro. É formado por duas etapas de avaliação: a de projeto e a de inspeção do edifício construído, onde se obtém a autorização para uso da etiqueta do Inmetro. 
Figura 30 - Modelo da Etiqueta Nacional de Conservação de Energia ENCE, neste caso apresentando níveis de eficiência A.

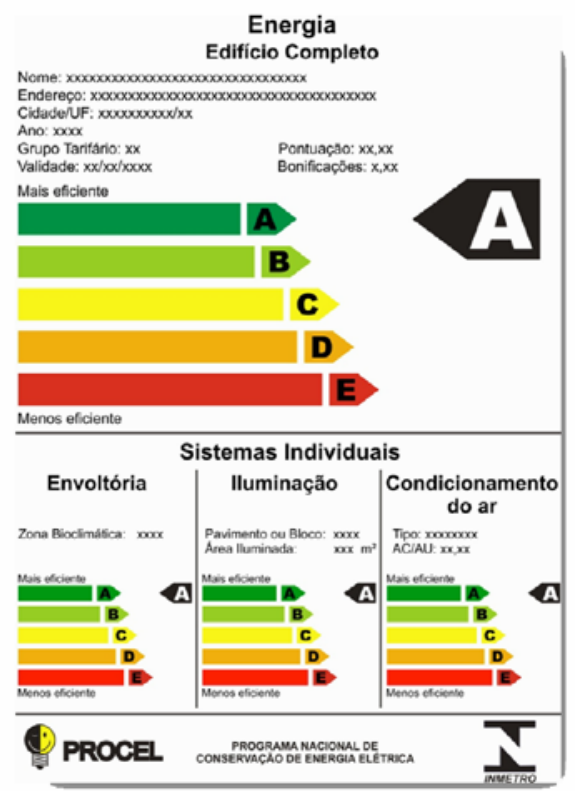

Fonte: PROCEL, 2012.

\subsection{Normas Internacionais}

A principal organização para o estudo da iluminação é a Comissão Internacional de lluminação (CIE - Commission Internationale de l'Éclairage), sediada em Viena, Áustria. Foi criada em 1913, com o intuito de cooperação e intercâmbio de informações entre seus países membros em questões relacionadas à ciência da luz e do estudo dos grandes problemas técnicos e científicos da iluminação. Atualmente, é representada por 38 países que indicam especialistas para colaborar na elaboração de normas, relatórios técnicos e recomendações científicas. As recomendações de aplicação da iluminação em diversos países têm origem na CIE.

A Divisão CIE do Brasil é representada pelo Inmetro, por sua Diretoria de Metrologia Científica e Industrial (DIMCl) e Divisão de Metrologia Óptica (DIOPT). A CIE também tem acordos de cooperação técnica com outras três entidades internacional:

Comissão Internacional de Eletrotécnica (IEC - International Electrotechnical Commission), fundada em 1906, é responsável pela padronização de equipamentos elétricos e desenvolve alguns padrões em comissões conjuntas com a ISO. É ela quem edita as normas para os 
produtos e é seguida por países europeus, Brasil e a maioria de outros continentes.

Organização Internacional para Padronização (ISO - International Organization for Standardization) - organização não governamental fundada em 1947, composta atualmente por 158 membros, cada um representando um país diferente, que produz padrões mundiais comerciais e industriais, que costumam ser adotados como leis em diversos países, uma vez que a organização age como um consórcio com fortes laços com os governos.

Comitê Europeu de Regulamentação (CEN - European Committee for Standardization), fundado em 1961, do qual fazem parte 30 países da Comunidade Européia. Ele tem o intuito de desenvolver padrões europeus voluntários (ENs). A CEN trabalha com as normas e padrões do CENELEC (European Committee for Electrotechnical Standardization), fundado em 1973, na área de engenharia elétrica.

Embora muito próximo da Comunidade Europeia, uma vez que seus 30 membros dela participam, o CENELEC não é uma organização da Comunidade.

Além desta associação (CIE) de caráter internacional, cada país possui a sua própria sociedade voltada a recomendações e regulamentações. Por exemplo, na Inglaterra é a BIES (British Illuminating Engineering Society) e nos Estados Unidos temos a IESNA (Illuminating Engineering Society of North America) e a ANSI (American National Standards Institute), está última uma organização privada, sem fins lucrativos, que administra e coordena o sistema norte-americano de standards e conformidades voluntários.

No caso de normas para aplicação da iluminação, os americanos seguem as recomendações da IESNA, que referencia os níveis de iluminâncias, redução de ofuscamento, uniformidade etc. Entretanto, eles seguem rígidas normas de controle de energia. O código de energia comum para todo o território americano é o ASHRAE 90.1, da American Society of Heating, Refrigerating and Air-Conditioning Engineers. Porém, se um Estado específico possui normas de energia mais restritivas, esse código se sobrepõe ao ASHRAE 90.1. 
4 DADOS SECUNDARIROS: TECNOLOGIAS APLICADAS NOS SISTEMAAS

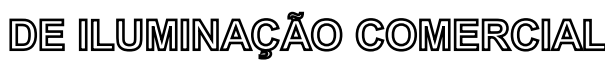

\subsection{Introdução}

Conforme dados da Associação Brasileira da Indústria de lluminação (ABILUX, 2005), o setor de iluminação está concentrado nas regiões Sudeste e Sul do Brasil, sendo 75\% das empresas sediadas no Estado de São Paulo, 5\% no Rio Grande do Sul, 4\% no Paraná, 4\% em Santa Catarina, 4\% no Rio de Janeiro, 4\% em Minas Gerais e 4\% em outros estados.

O setor atua de forma dividida dentro das seguintes áreas de atuação: lâmpadas e starters; reatores, ignitores e transformadores; iluminação comercial; iluminação industrial; iluminação pública; iluminação cênica; iluminação publicitária; projetista de Iluminação; e componentes para indústria de iluminação.

É no segmento de iluminação residencial e decorativa onde se concentra a maior atuação das empresas do setor, correspondendo a 23\%, seguido pelos segmentos de iluminação comercial (18\%) e industrial (13\%), conforme exemplifica a Figura 31. A Figura 32 aponta, em percentual, a quantidade de empresas que atuam em cada segmento.

Figura 31 - Área de atuação das empresas do setor de iluminação.
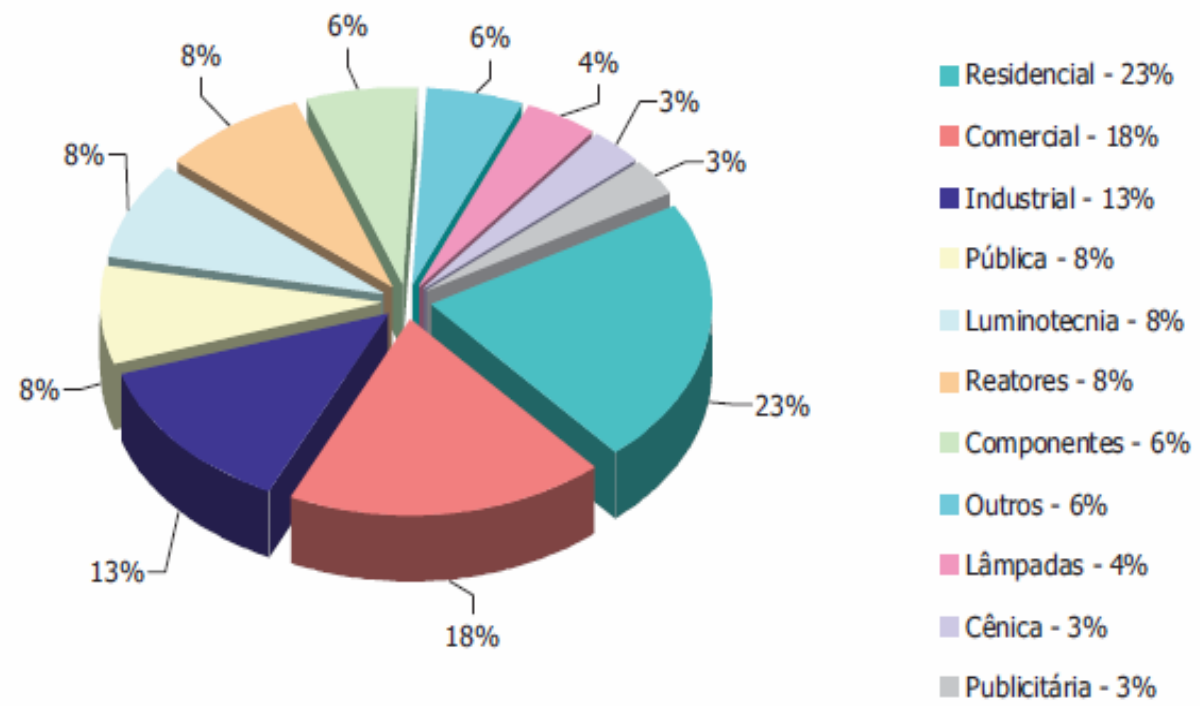

Fonte: ABILUX, 2005. 
Figura 32 - Percentual por área de atuação do setor de iluminação

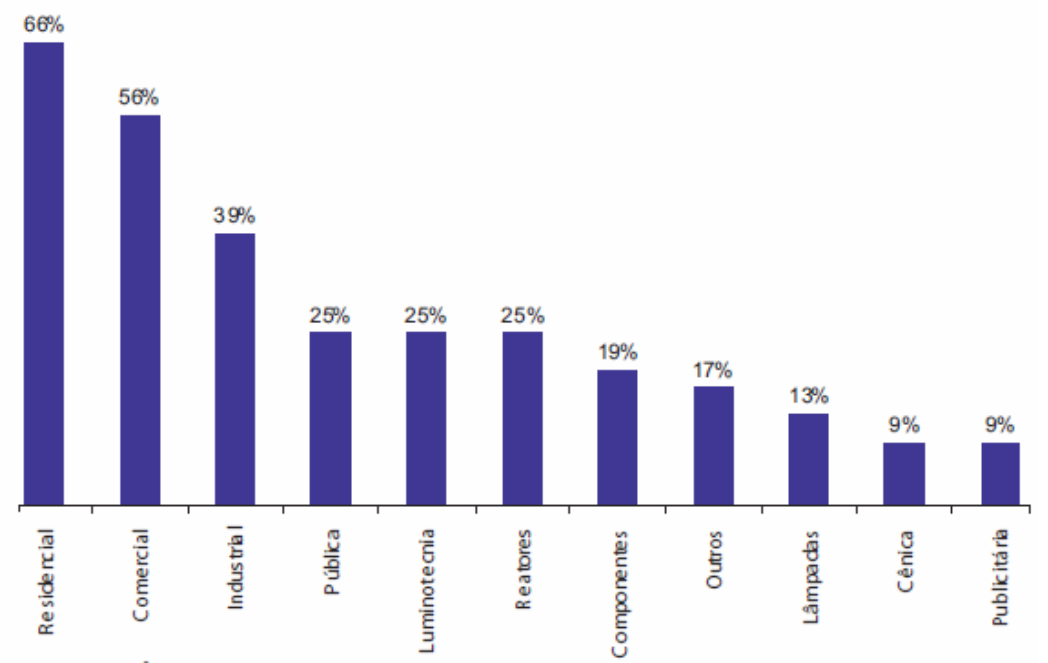

Fonte: ABILUX, 2005.

A linha de produtos fabricados pelo setor, embora muito diversificada, também é bem homogênea. Entretanto, percebe-se um maior destaque para os produtos desenvolvidos pelo segmento de iluminação residencial e decorativa, como arandelas (9\%), pendentes (9\%), plafons (8\%), luminárias para mesa (7\%), abajures (7\%), luminárias fluorescentes ( $6 \%$ ) e reatores (3\%), conforme Figura 31.

Figura 33 - Principais produtos fabricados pelo setor de iluminação

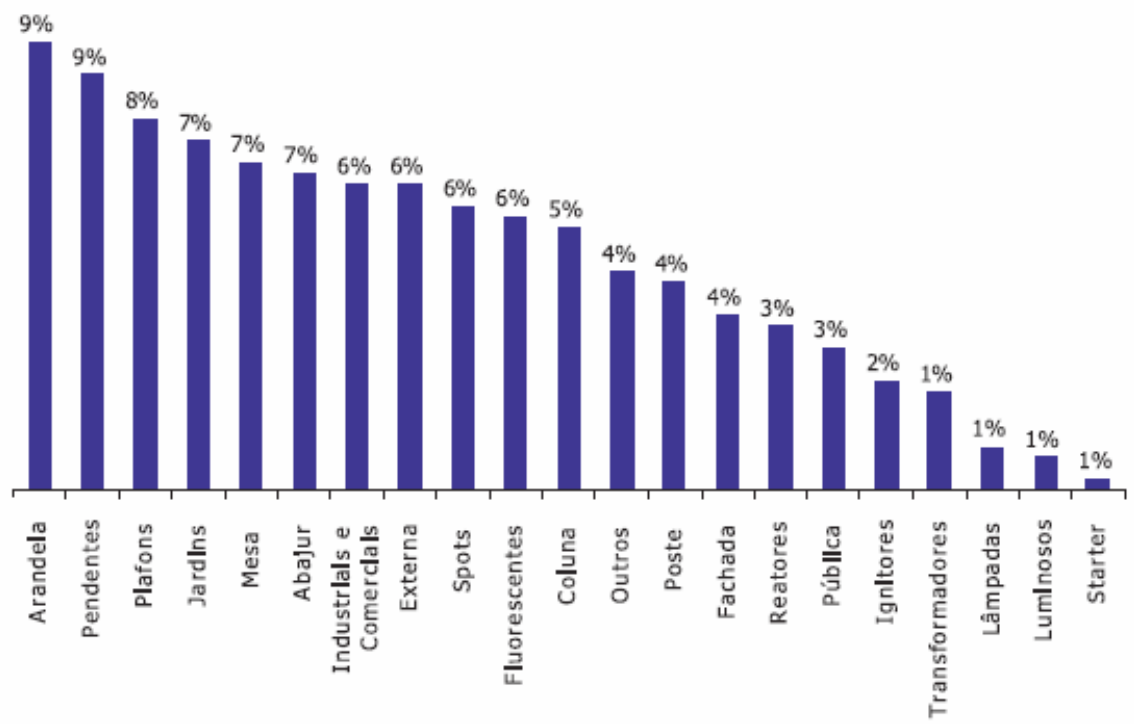

Fonte: ABILUX, 2005. 
As grandes empresas de lâmpadas são responsáveis por 50\% do faturamento, sendo as duas maiores a Philips e a Osram, seguidas pela Sylvania e pela GE - General Electric;

No restante do mercado, $20 \%$ são empresas médias e $30 \%$ microempresas. Ressalte-se que essas empresas estão focadas prioritariamente na distribuição de lâmpadas e equipamentos auxiliares e dedicam menor atenção às luminárias.

A Osram do Brasil, sediada na cidade de Osasco (SP), é a única a manter atividades fabris no país, produzindo lâmpadas incandescentes, fluorescentes tubulares T10 e T8 e lâmpadas de descarga em alta pressão, de vapor de sódio, vapor de mercúrio e vapor metálico, além da linha automotiva.

As matérias-primas ou componentes representam em torno de $48 \%$ do custo total dos produtos, sendo que, das principais itens utilizados na fabricação de produtos do setor, $20 \%$ é importado e $80 \%$ de produção nacional, conforme dados a seguir:

Tabela 13 - Matérias-primas na fabricação de luminárias

\begin{tabular}{|l|l|l|}
\hline & Importada & Nacional \\
\hline Componentes (porta-lâmpada, soquetes etc.) & $32 \%$ & $68 \%$ \\
\hline Fios e cabos & $9 \%$ & $91 \%$ \\
\hline Alumínio & $16 \%$ & $84 \%$ \\
\hline Aço & $0 \%$ & $100 \%$ \\
\hline
\end{tabular}

Fonte: ABILUX, 2005.

\subsection{Luminárias de uso comercial e de serviços}

A luminária é um aparelho que distribui, filtra ou transforma a luz emitida por uma ou mais lâmpadas e que compreende, com exceção das próprias lâmpadas, todas as partes imprescindíveis para sustentar, fixar e protegê-las, e, quando necessário, os equipamentos auxiliares, bem como os meios para ligá-los à rede de alimentação. 
Somente com a emissão de luz pela lâmpada não há como garantir a perfeita distribuição. Através da seleção de material e o projeto de um bom sistema ótico, a luminária pode maximizar o uso da luz emitida pela lâmpada.

As lâmpadas e os equipamentos auxiliares evoluíram muito ao longo das últimas décadas, através de muita pesquisa e do desenvolvimento dos grandes fabricantes, que passaram a ter como grande objetivo fornecer sistemas de iluminação de elevada qualidade, padronizados, normatizados e com um total engajamento na preservação do meio ambiente. Com lâmpadas e equipamentos mais eficientes e de maior durabilidade, é possível reduzir o consumo de energia, de resíduos, dos custos de aquisição, de manutenção e de emissão de $\mathrm{CO}^{2}{ }^{13}$.

Principalmente nas instalações com atividades laborativas, a iluminação mais eficiente é aquela que combina lâmpadas de elevada eficiência energética com reatores eletrônicos e módulos de gerenciamento. A operação eletrônica garante não apenas longa durabilidade, mas também uma operação econômica, livre de interferência e com alta qualidade.

As luminárias mais comuns são fabricadas para os seguintes tipos de lâmpadas: incandescentes, fluorescentes tubulares, fluorescentes compactas, de indução, de alta pressão, sódio de baixa pressão e as que utilizam diodos emissores de luz, como os LEDs (Light Emmiting Diode). Cada tipologia tem as suas próprias particularidades, tratadas nas Normas ABNT NBR IEC 60598-1/2010 - Luminárias - Parte 1 : Requisitos gerais e ensaios e na NBR IEC 60598-2-1/2012 - Luminárias - Parte 2: Requisitos particulares - Capítulo 1: Luminárias fixas para uso geral em iluminação, que parametriza a utilização com lâmpadas de filamento de tungstênio, lâmpadas tubulares fluorescentes e com outras lâmpadas de descarga nas tensões de alimentação que não excedam $1.000 \mathrm{~V}$.

As luminárias que utilizam uma ou duas lâmpadas fluorescentes tubulares são as do tipo mais frequentemente usado na iluminação comercial e de serviços, como, por exemplo, em escritórios, agências bancárias, lojas, hospitais e clínicas, restaurantes e hotéis, depósitos etc. Podem ser utilizadas nas aplicações industriais, quando a altura de montagem é menor que 5 a 6 metros.

\footnotetext{
${ }^{13} \mathrm{CO}^{2}$. Dióxido de carbono
} 
Tamanho, material, propriedades térmicas, desempenho fotométrico e tensão da luminária dependem do tipo de lâmpada a ser utilizada, mas o que difere uma luminária de outra é o tipo de controle de luz e, portanto, o tipo de distribuição de intensidade luminosa ${ }^{14}$.

Os quatro tipos mais comuns de componentes para controle de luz são: refletores, conforme figura 34, refratores, difusores e grelhas (louver) ou protetores.

O refletor da luminária é o dispositivo feito geralmente de metal revestido ou plástico que tenha alta refletância. A forma é dada de maneira que redirecione a luz emitida pela lâmpada por reflexão e o acabamento dos refletores é classificado em especular, semi-especular, fosco (matt), texturizado, martelado e frisado, conforme ilustrado na figura 35

Figura 34 - Refletores especulares para lâmpadas fluorescentes tubulares

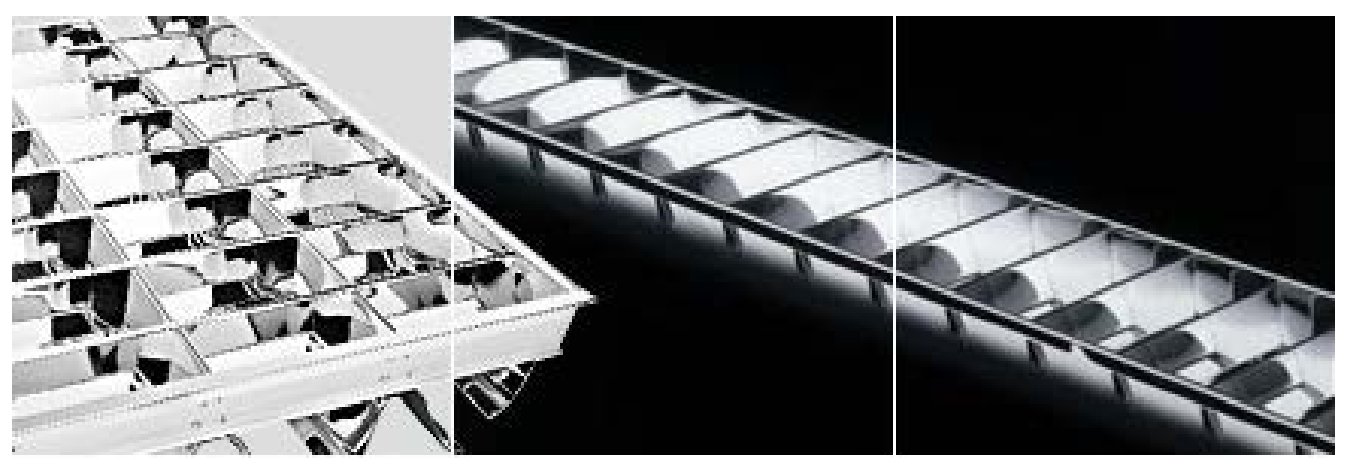

Fonte: ALMECO, 2009.

Os refletores feitos de plástico normalmente recebem um tratamento de metalização a vácuo. O processo é simples e de baixo custo, no qual camadas de metal ou de não metal relativamente frias são depositadas em alto vácuo, sobre superfícies preparadas, que podem ser de plástico, metais, vidros ou de outros materiais. Na maioria dos produtos, a metalização a vácuo tem finalidade apenas decorativa.

Às vezes, o refletor não precisa ter um direcionamento preciso, bastando ter uma boa refletância. Um exemplo disto são os refletores de

\footnotetext{
${ }^{14}$ Intensidade luminosa- De uma fonte, numa dada direção, é a razão do fluxo luminoso de Фy que sai da fonte e se propaga no elemento de ângulo sólido, cujo eixo coincide com a direção considerada para esse elemento de ângulo: Unidade: candela - cd.
} 
metal pintados de branco, utilizados em luminárias para lâmpadas incandescentes e fluorescentes compactas. Com o tempo, essa superfície vai amarelando e perdendo a sua capacidade de reflexão, principalmente devido à emissão de calor emitido pela fonte de luz.

Refletores especulares têm maior capacidade de aproveitamento, reflexão e direcionamento da luz emitido pelas lâmpadas, mas podem causar ofuscamento se não houver um bom projeto do sistema ótico.

Figura 35- Acabamentos de superfícies de alumínio: acabamento especular (espelhado), semi-especular, fosco (matt) e acetinado (texturizado).

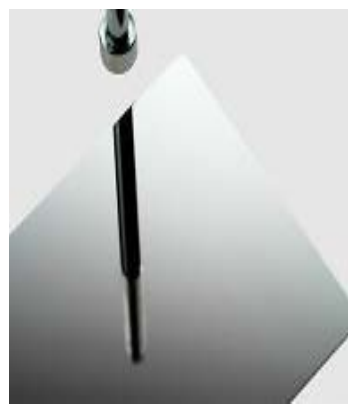

Especular

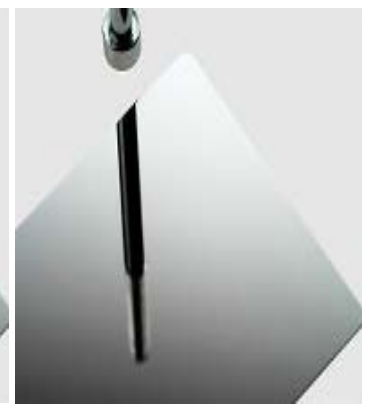

Semi-especular

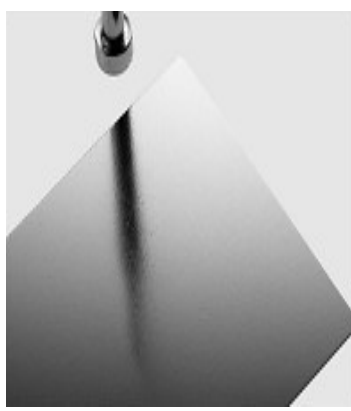

Fosco (matt)

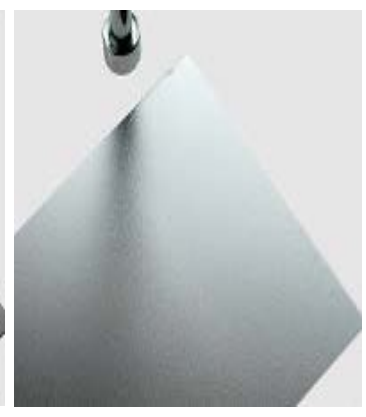

Texturizado

Fonte: ALMECO, 2012.

As características de reflexão dos alumínios altera o comportamento da saída de luz, mesmo sendo alguns modelos similares na aparência, e podem obter resultados distintos.

O bom alumínio anodizado, com acabamento especular, tem elevada reflexão no plano transversal e longitudinal, com uma reflexão total na ordem de 85\%; porém, sua reflexão difusa não é elevada.

O alumínio anodizado semiespecular, também conhecido como fosco ou matt, tem elevada reflexão em torno de $84 \%$, mas sua capacidade de reflexão difusa é bem elevada; por esse motivo, não é indicado para "direcionamento" da luz, mas é excelente no critério de conforto visual.

Quando o alumínio é anodizado posteriormente ao manuseio da luminária - seja matt ou alto brilho - há uma perda de apenas 20\% da intensidade luminosa, restando, portanto, $80 \%$ no que é refletido. 
Teoricamente, quanto maior a refletância, maior será o rendimento de uma luminária. Para exemplificar, temos as figuras 36, 37 e 38, que demonstram as condições que a reflexão, ja que é o fenômeno no qual parte da luz que atinge uma superfície, e muda de direção, voltando para o seu meio de origem.

A reflexão da luz depende qualitativa e quantitativamente das condições das superfícies refletoras e do ângulo de incidência dos raios luminosos.

Figura 36- Reflexão Especular
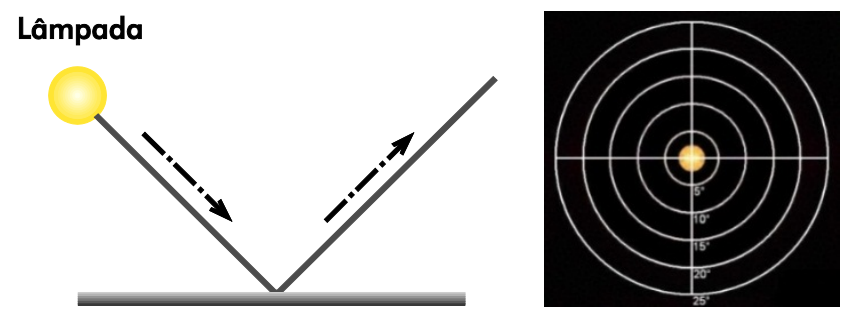

Figura 37 -Reflexão difusa
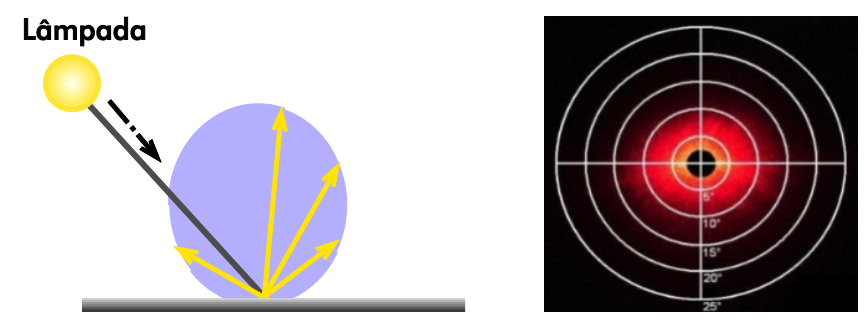

Figura 38 - Reflexão Total
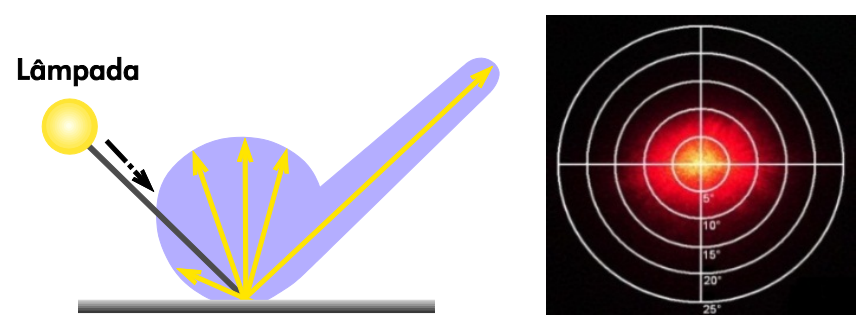

Fonte: ALMECO, 2010.

Alguns desses materiais não têm a capacidade de refratar a luz ou de reduzir a separação de cores por reflexão, e essa manifestação é conhecida por iridescência. Trata-se de um fenômeno ótico, caracterizado pela propriedade de determinadas superfícies em que o tom da luz varia de acordo com o ângulo da superfície observada. 
Quando a camada de anodização é muito espessa, acontece esse efeito, no qual surge uma tonalidade verde e rosa no alumínio, que pode ser vista de determinados ângulos. Trata-se de uma reflexão do espectro de luz de forma desigual, tornando visíveis as cores que compõem a luz branca original. O alumínio MATT ${ }^{15}$ apresenta menor iridescência que o alto brilho. Quanto menor o grau de iridescência, maior a qualidade do alumínio, mas este efeito interfere apenas esteticamente e sob o ponto de vista do conforto visual. Não há perda na reflexão da luz nem comprometimento com relação à durabilidade do produto ou à eficiência da luminária.

Tabela 14 - Classificação adotada de iridescência dos alumínios de 1 a 4.

\begin{tabular}{|l|l|}
\hline $1=$ & Normal \\
\hline $2=$ & Baixa \\
\hline $3=$ & muito baixa \\
\hline $4=$ & sem iridescência \\
\hline
\end{tabular}

Fonte: ALMECO, 2007.

Em alguns casos, os refletores têm propriedades que variam de acordo com o comprimento de onda. Para isso, camadas de materiais alternativos, com diferentes índices de refração, são aplicadas ao vidro. Os efeitos dessa interferência produzem uma reflexão que acarreta mudanças de acordo com o comprimento de onda.

O refrator permite a mudança da direção da luz no momento em que ela passa pelos limites de materiais com diferentes densidades ópticas, como, por exemplo, do ar para o vidro ou do ar para acrílico.

O material utilizado é normalmente o vidro ou acrílico, moldados de forma que a luz é redirecionada ao passar pelo material. Essa refração é dada por meio de prismas, que são extrudados (levantados) da superfície do material ou estão nela gravados.

Pequenos prismas agindo em conjunto podem destruir as imagens parcialmente, escurecer lâmpadas e reduzir a luminância. Em alguns casos,

${ }^{15}$ Alumínio Matt- Considerado o alumínio fosco, com reflexão especular longitudinais $\left(60^{\circ}\right)$ 45 ; transversal $\left(60^{\circ}\right)$ - 30 ; Reflexão total TR2 84 ; Reflexão difusa 78 e sem iridescência. 
a folha que contém os prismas utilizados na fabricação dos refratores é confeccionada de forma que proporcione um controle adicional da luz.

Outra aplicação dos refratores se aproveita da reflexão interna total. Nesse caso, o material refratário é moldado de forma que a luz passe por sua primeira superfície, e a maior parte seja refletida da segunda superfície de volta para o material, e dali para fora da primeira superfície.

O difusor é o elemento que controla a luz, redirecionando a luz incidente em várias direções. O difusor pode ser de vários materiais, como peças em plástico branco, vidros serigrafados ou jateados.

Máscaras, protetores, grelhas e defletores são feitos de materiais opacos ou translúcidos, para reduzir ou eliminar a visão direta da lâmpada na luminária. Eles servem muitas vezes para controlar a chamada reflexão veladora ou ofuscamento refletido. Se o arranjo é em uma grade retangular, produzindo pequenas divisões, são chamadas grelhas. Se o arranjo é linear, são chamados defletores (IES, 2000).

Os componentes mecânicos fazem parte do envoltório, a estrutura geral da luminária e o mecanismo de montagem para fixar a luminária.

Figura 39 - Exemplos a e b de componentes mecânicos das luminárias para lâmpadas fluorescentes tubulares lineares.
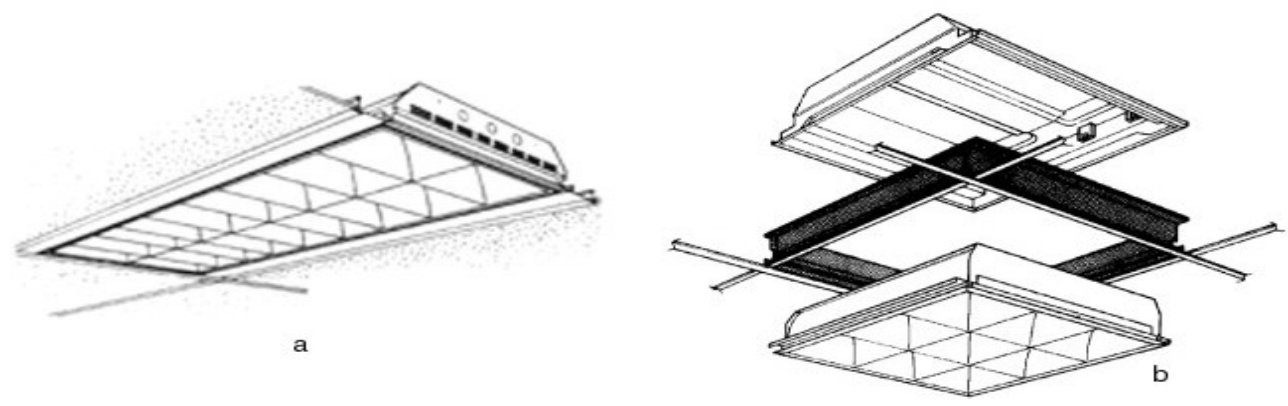

Fonte: IES Handbook, 2000.

Se a luminária utilizar um refrator ou uma lente transparente, a estrutura ou as tampas de fechamento articuladas têm normalmente um 
dispositivo para prender essas lentes. O acesso para a limpeza e troca da lâmpada é feito através dessas "tampas".

Muitas luminárias embutidas são ventiladas para que haja dissipação do calor, que normalmente acarreta diminuição do desempenho da lâmpada. Em alguns edifícios, as luminárias são utilizadas como parte integrante dos sistemas de aquecimento, ventilação e ar condicionado. As luminárias do tipo "de embutir", para luz direta, são utilizadas normalmente para luz geral ou ambiente, e são projetadas para produzir iluminação em um piso ou plano de trabalho.

Figura 40 - Exemplos modelos d, e e f de luminárias tipo downlight (luz direta).
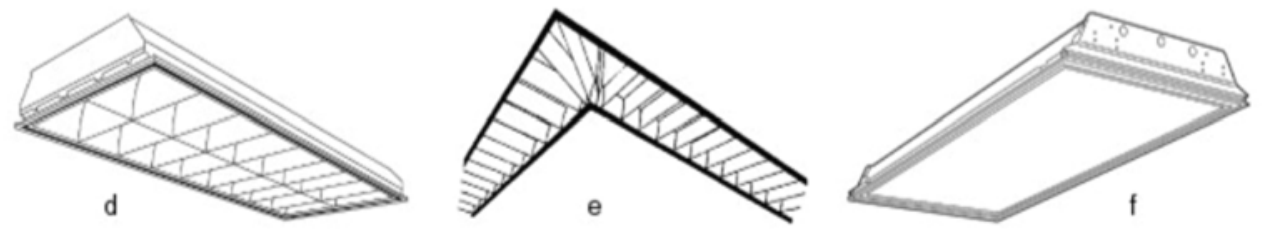

Fonte: IES Handbook, 2000.

Figura 41 - Sala de conferência com aplicação de luminária tipo downlight, com lâmpadas fluorescentes tubulares T5 14W/840.

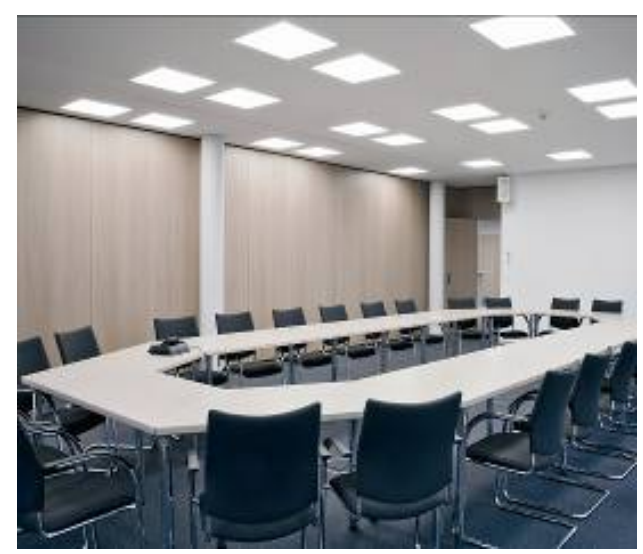

Fonte: OSRAM.

As luminárias de sobrepor, normalmente são utilizadas para uma luz geral ou ambiente, permitindo o uso direto na laje. 
As luminárias tipo wall washer, produzem a distribuição da luz para a parede, não necessariamente de forma uniforme. Elas podem ser simétricas ou assimétricas, de embutir ou de sobrepor.

O trilho é um acessório de montagem que fornece alimentação elétrica. Normalmente afixado no forro ou próximo dele, também pode ser embutido e instalado na vertical ou na horizontal. Pode ser alimentado por um fio conectado na ponta do trilho ou em qualquer outro ponto no seu comprimento, e, ainda, ser mais flexível se for utilizado um conjunto de cabo e plugue, para fornecer a energia.

Figura 42 - Exemplos de modelos a, b, c e d de luminárias de sobrepor fluorescentes lineares.

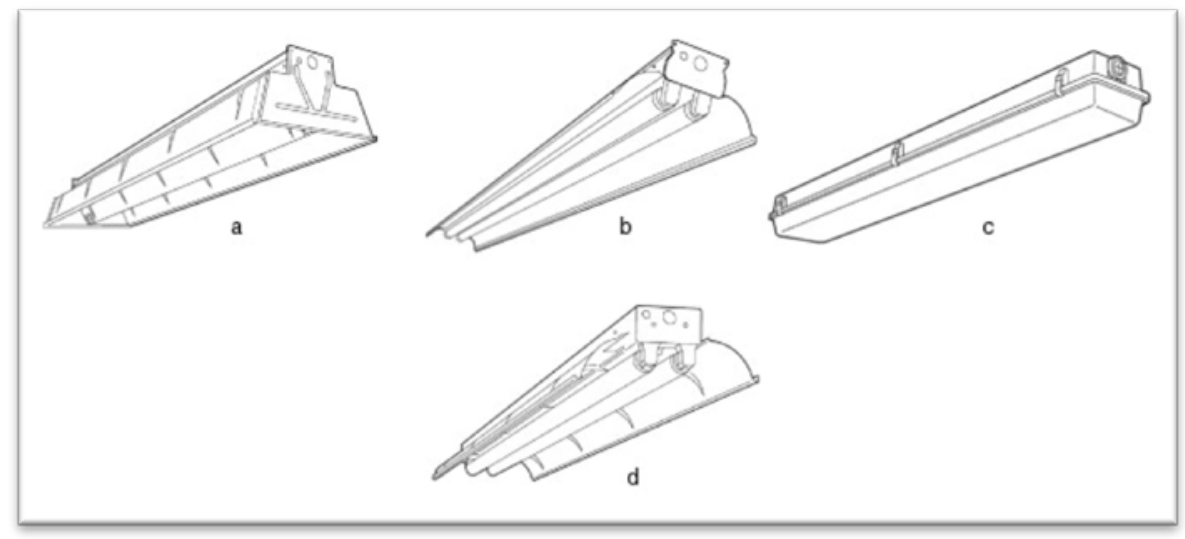

Fonte: IES Handbook, 2000.

Figura 43- Escritório corporativo, aplicação de luminária de sobrepor

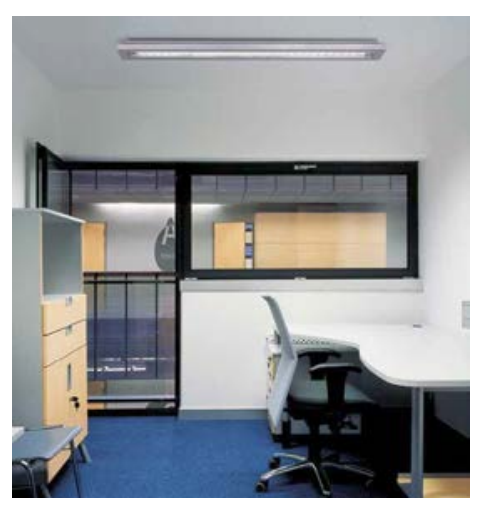

Fonte: SITECO, OSRAM,2012. 


\subsubsection{Classificação das luminárias}

Conforme a norma NBR IEC 60598-1- Luminárias - Parte 1: Requisitos gerais e ensaios, as luminárias são classificadas de acordo com o tipo de proteção contra choque elétrico, o grau de proteção, contra a penetração de pó, objetos sólidos e umidade, e o material de sua superfície de apoio, sendo:

- Proteção contra choque elétrico: as luminárias devem ser classificadas de acordo com o tipo de proteção contra choque elétrico, como classe 0 , classe I, classe II ou classe III.

- Luminária classe 0 (aplicável somente a luminárias comuns) - luminária em que a proteção contra choque elétrico é realizada por meio da isolação básica. Isto implica no fato de que não há meios para conexão de partes condutoras acessíveis, se existirem, ao condutor de proteção da fiação fixa da instalação. A confiança passa a ser depositada no ambiente, no caso de falha da isolação básica. É considerada uma luminária comum quando apresenta proteção contra contato acidental com partes vivas, porém sem nenhuma outra proteção especial contra pó, objetos sólidos ou umidade.

- Luminária classe I - luminária em que a proteção contra choque elétrico não é realizada somente pela isolação básica, mas na qual é incluída uma medida adicional de segurança, de modo que são previstos meios para a conexão de partes condutoras acessíveis ao condutor de proteção (aterramento) da fiação fixa da instalação, de maneira que estas partes condutoras acessíveis não possam se tornar vivas, no caso de falha da isolação básica.

- Luminária classe II - luminária na qual a proteção contra choque elétrico não é feita somente pela isolação básica, mas na qual devem ser providenciadas medidas adicionais de segurança, como isolação dupla 
ou isolação reforçada, não havendo provisão de nenhum meio de proteção se apoiando no aterramento ou nas condições da instalação.

- Luminária classe III - luminária na qual a proteção contra choque elétrico é baseada na alimentação por extra-baixa tensão de segurança (EBTS/SELV), onde não são geradas tensões superiores à EBTS/SELV ${ }^{16}$.

- Grau de Proteção - o sistema de identificação IP (Ingress Protection) é utilizado para classificar as luminárias de acordo com o grau de proteção contra agentes exteriores, de todo o sistema elétrico. Portanto, as luminárias devem ser construídas para suportar determinadas condições de trabalho em termos de penetração de corpos estranhos ${ }^{17}$, vedação a insetos, poeira, água e resistência a determinados impactos e danos mecânicos.

Essas características, que dependem da utilização de luminárias, são definidas pelo seu grau de proteção IP:

a) Proteção de pessoas contra contato ou proximidade de partes vivas e contra contato com partes móveis (exceto eixos lisos rotativos ou similares), no interior do compartimento; e proteção do equipamento contra o ingresso de corpos sólidos externos.

b) Proteção de equipamento no interior do compartimento contra ingresso prejudicial de água.

A designação para indicar os graus de proteção consiste nas letras características IP, seguidas pelos dois numerais (os "numerais característicos"), indicando conformidade com as condições estabelecidas nas Tabelas 15 e 16, respectivamente. Conforme descrito acima, o primeiro numeral indica o grau de proteção descrito no item a), e o segundo o grau de proteção descrito no item b).

${ }_{16}$ EBTS/SELV - Extra Baixa Tensão / Extra Baixa Tensão de Segurança.

${ }^{17}$ Corpos estranhos -- o termo corpos estranhos inclui elementos como parte de corpos humanos, objetos ou ferramentas, que possam entrar em contato com as partes vivas da luminária. A IEC 60259 apresenta detalhes sobre o tipo de proteção coberto pela classificação. 
Tabela 15 - Grau de proteção indicado pelo primeiro numeral característico, contra ingresso de corpos sólidos externos.

\begin{tabular}{|c|c|c|}
\hline \multirow{2}{*}{$\begin{array}{l}\text { Primeiro } \\
\text { numeral }\end{array}$} & \multicolumn{2}{|l|}{ Grau de Proteção } \\
\hline & Descrição suscinta & $\begin{array}{l}\text { Detalhes breves dos objetos que } \\
\text { serão "excluídos" do invólucro }\end{array}$ \\
\hline 0 & Não protegido & Nenhuma proteção especial \\
\hline 1 & $\begin{array}{l}\text { Protegido contra objetos } \\
\text { sólidos maiores que } 50 \\
\mathrm{~mm}\end{array}$ & $\begin{array}{l}\text { Uma grande superfície do corpo, como } \\
\text { uma mão (mas sem proteção contra o } \\
\text { acesso deliberado). Objetos sólidos com } \\
\text { diâmetro superior a } 50 \mathrm{~mm}\end{array}$ \\
\hline 2 & $\begin{array}{l}\text { Protegido contra objetos } \\
\text { sólidos maiores que } 12 \\
\mathrm{~mm}\end{array}$ & $\begin{array}{l}\text { Dedos ou objetos similares não } \\
\text { excedendo } 80 \mathrm{~mm} \text { de comprimento. } \\
\text { Objetos sólidos com diâmetro superior a } \\
12 \mathrm{~mm}\end{array}$ \\
\hline 3 & $\begin{array}{l}\text { Protegido contra objetos } \\
\text { sólidos maiores que } 2,5 \\
\mathrm{~mm}\end{array}$ & $\begin{array}{l}\text { Ferramentas, fios etc., de diâmetro ou } \\
\text { espessura maior que } 2,5 \mathrm{~mm} \text {. Objetos } \\
\text { sólidos com diâmetro superior a } 2,5 \\
\mathrm{~mm}\end{array}$ \\
\hline 4 & $\begin{array}{l}\text { Protegido contra objetos } \\
\text { sólidos maiores que } 1,0 \\
\mathrm{~mm}\end{array}$ & $\begin{array}{l}\text { Fios ou fitas de espessura maior que } 1,0 \\
\text { mm. Objetos sólidos com diâmetro } \\
\text { superior a } 1,0 \mathrm{~mm}\end{array}$ \\
\hline 5 & Protegido contra pó & $\begin{array}{l}\text { O ingresso de pó não é totalmente } \\
\text { prevenido, mas este não entra em } \\
\text { quantidade suficiente para interferir com } \\
\text { a operação satisfatória do equipamento. }\end{array}$ \\
\hline 6 & Hermético a pó & Sem ingresso de pó \\
\hline
\end{tabular}

Fonte: ABNT NBR IEC 60598-1/2010 - Luminárias- Parte 1: requisitos gerais e ensaios. 
Tabela 16 - Grau de proteção indicado pelo segundo numeral característico, contra ingresso de água.

\begin{tabular}{|c|c|c|}
\hline \multirow{2}{*}{$\begin{array}{l}\text { Segundo } \\
\text { numeral }\end{array}$} & \multicolumn{2}{|l|}{ Grau de Proteção } \\
\hline & $\begin{array}{l}\text { Descrição } \\
\text { sucinta }\end{array}$ & $\begin{array}{l}\text { Detalhes do tipo de proteção fornecido } \\
\text { pelo invólucro }\end{array}$ \\
\hline 0 & Sem proteção & Sem proteção especial \\
\hline 1 & $\begin{array}{l}\text { Protegido contra } \\
\text { gotejamento }\end{array}$ & $\begin{array}{l}\text { Gotejamento de água (queda de gotas } \\
\text { verticais): não deve ter efeito nocivo. }\end{array}$ \\
\hline 2 & $\begin{array}{l}\text { Protegido contra } \\
\text { gotejamento de } \\
\text { água, quando } \\
\text { inclinado até } 15^{\circ} \text {. }\end{array}$ & $\begin{array}{l}\text { Gotejamento vertical de água não deve ter } \\
\text { efeito nocivo quando o invólucro é } \\
\text { inclinado até um ângulo de } 15^{\circ} \text {, a partir de sua } \\
\text { posição normal. }\end{array}$ \\
\hline 3 & $\begin{array}{l}\text { Protegido contra } \\
\text { água pulverizada. }\end{array}$ & $\begin{array}{l}\text { Água pulverizada caindo com um ângulo de } \\
\text { até } 60^{\circ} \mathrm{com} \text { a vertical não deve ter efeito nocivo. }\end{array}$ \\
\hline 4 & $\begin{array}{l}\text { Protegido contra } \\
\text { água borrifada. }\end{array}$ & $\begin{array}{l}\text { Água borrifada contra o invólucro, de qualquer } \\
\text { direção, não deve ter efeito nocivo. }\end{array}$ \\
\hline 5 & $\begin{array}{l}\text { Protegido contra } \\
\text { jatos de água. }\end{array}$ & $\begin{array}{l}\text { Água projetada por um bico, sob pressão, } \\
\text { contra o invólucro, de qualquer direção, } \\
\text { não deve ter efeito nocivo. }\end{array}$ \\
\hline 6 & $\begin{array}{l}\text { Protegido contra } \\
\text { ondas de grande } \\
\text { porte }\end{array}$ & $\begin{array}{l}\text { Água de ondas de grande porte, ou água } \\
\text { projetada em jatos potentes, não deve penetrar } \\
\text { no invólucro em quantidades prejudiciais. }\end{array}$ \\
\hline 7 & $\begin{array}{l}\text { Protegido contra } \\
\text { os efeitos da } \\
\text { imersão }\end{array}$ & $\begin{array}{l}\text { O ingresso de água em quantidade } \\
\text { prejudicial não deve ser possível, quando } \\
\text { o invólucro é imerso em água em } \\
\text { condições definidas de pressão e tempo. }\end{array}$ \\
\hline 8 & $\begin{array}{l}\text { Protegido contra } \\
\text { submersão }\end{array}$ & $\begin{array}{l}\text { O equipamento é adequado para submersão } \\
\text { contínua em água, sob condições que devem } \\
\text { ser especificadas pelo fabricante. } \\
\text { Nota: normalmente, isto significa que o } \\
\text { equipamento é hermeticamente selado. } \\
\text { Entretanto, com certos tipos de equipamentos, } \\
\text { isto pode significar que a água é capaz de } \\
\text { entrar, mas somente de um modo que não } \\
\text { produza efeitos nocivos. }\end{array}$ \\
\hline
\end{tabular}

Fonte: ABNT NBR IEC 60598-1/2009 - Luminárias- Parte 1: requisitos gerais e ensaios. 
Proteção com relação ao material da superfície de apoio: as luminárias e componentes elétricos da instalação são classificados conforme sejam adequadas, em todos os casos, para montagem direta sobre superfícies normalmente inflamáveis, ou seja, adequadas para montagem sobre superfícies não combustíveis:

- Luminárias adequadas para montagem sobre superfícies normalmente inflamáveis - Temperatura máxima de $180^{\circ} \mathrm{C}$ na superfície de montagem;

-Luminárias adequadas para montagem direta em/sobre superfícies inflamáveis normais, quando um material isolante térmico pode cobrir a luminária - Temperatura máxima de $130^{\circ} \mathrm{C}$ na superfície de montagem;

- Luminárias não adequadas para montagem sobre superfícies normalmente inflamáveis.

As técnicas de limpeza especializada não estão cobertas pelos índices de grau de proteção IP, onde se faz necessário que os fabricantes forneçam a informação apropriada referente às técnicas de limpeza. Isto está de acordo com as recomendações contidas na ABNT NBR IEC 60529 para técnicas de limpeza especializada.

\subsubsection{A concepção da luminária funcional}

Devem ser considerados, códigos e padrões para sua construção e instalação, para características físicas e ambientais, para considerações elétricas e mecânicas, propriedades térmicas, segurança e fatores econômicos; quanto maior a fonte luminosa, maior será o refletor requerido para promover um controle ótico equivalente.

Efeitos secundários do refletor podem ocorrer devido ao projeto. Por exemplo, se a energia refletida for concentrada na lâmpada, pode prejudicar seu funcionamento; se o feixe de luz for concentrado na parte frontal das lentes, o vidro pode apresentar problemas devido às altas temperaturas.

Posicionamento e recolocação da lâmpada são fundamentais, pois muitas delas são projetadas somente para uma determinada posição de funcionamento, quer seja em pé, deitada etc.

Uma consideração básica é que a inserção e a remoção da lâmpada devem ser de fácil acesso. 
A eficiência da luminária se dá em função da configuração física e da escolha correta dos materiais utilizados. O projetista deve coordenar a parte técnica, a segurança e as considerações econômicas com a aparência final da luminária.

Os esforços do projeto são concentrados geralmente em refletores, refratores e na proteção dos elementos mecânicos da luminária. Pode ser desejável sacrificar o melhor desempenho, a fim de alcançar proporções e formas agradáveis.

O brilho/ofuscamento (glare) é desconfortável e prejudicial. O grau de controle da luminância a ser projetada em uma peça depende do uso pretendido e do ambiente luminoso em que ela será utilizada.

A distribuição térmica é parte da integração das luminárias na manipulação do ar e os aspectos arquitetônicos de um edifício influenciam na construção básica das luminárias. Alguns materiais usados nas luminárias podem ser bons refletores da luz e bons absorventes da radiação infravermelha.

A ventilação e a circulação de ar na luminária podem resultar na acumulação de poeira e de sujeira, trazendo prejuízos à saída de luz. Quando há presença de vibração, devem ser utilizados soquetes resistentes a esse fator, como também caixas que o absorva. No caso de lâmpadas fluorescentes, devem ser utilizados suportes com molas.

A radiação eletromagnética das lâmpadas de descarga a gás especialmente do tipo fluorescente - e dos componentes auxiliares podem ser suficientes para causar interferência em rádios próximos, receptores de televisão, equipamentos médicos, radares e a outras peças eletrônicas sensíveis. Esta interferência é transmitida pela radiação direta, através da luminária e pela condução pelo reator.

Para eliminar a radiação eletromagnética direta, a luminária deve ser envolvida inteiramente em metal, à exceção da abertura de luz. A alimentação elétrica deve ser realizada através de canalização aterrada ou de cabo protegido. Os filtros de linha apropriados podem isolar a interferência.

A vida útil e a manutenção dependem da habilidade da luminária em suportar as circunstâncias ambientais da área em que está instalada. Nos 
casos onde a ação eletrolítica pode ocorrer, o uso de ligas com elevado índice de cobre no alumínio devem ser evitadas. Deve haver sempre uma boa ventilação, vedação e filtração do ar para minimizar o efeito da sujeira.

O efeito de altas e baixas temperaturas nas luminárias e em seus componentes também deve ser considerado. Em ambientes industriais, ocorrem temperaturas que chegam a $65^{\circ} \mathrm{C}$. Áreas de refrigeração trabalham com temperaturas de até $-29^{\circ} \mathrm{C}$. A radiação emitida pela lâmpada pode alterar a cor das pinturas, desbotamento ou causar degradação dos plásticos.

Considerações mecânicas, térmicas e de segurança, são fundamentais para o bom desempenho do sistema, sendo:

- Considerações Mecânicas - Os suportes da lâmpada e os soquetes devem ser afixados de forma que impeçam o movimento e mantenham o bom contato da lâmpada. É interessante que os soquetes sejam bem afixados e, em determinados casos, que também haja sustentação na extremidade. Os reatores devem ser prendidos firmemente à carcaça, para que tenham um bom contato térmico. Os vidros de fechamento, as lentes e os refratores devem ser firmemente afixados para suportar os efeitos do vento, da chuva ou de choques. Em alguns ambientes específicos, como áreas públicas, hospitais e cadeias, deve ser assegurado que as tampas das luminárias sejam chumbadas.

- Considerações Térmicas - As propriedades de dissipação do calor na própria luminária afetam o seu desempenho. De acordo com a variação térmica, os vidros podem se romper e componentes plásticos podem ser deformados. Os componentes devem ser escolhidos de maneira a evitar rachaduras, quebras, deformações ou quaisquer outras deteriorações.

- Considerações de Segurança - Para garantir uma luminária segura, deve-se considerar: a capacidade atual de carga dos condutores, o isolamento dos condutores, o aterramento, a temperatura dos condutores, as conexões nas caixas de junção, a cor dos fios elétricos, a força 
mecânica e flexibilidade, os interruptores de segurança, os fusíveis e protetores térmicos, as talas, afastamentos e soquetes.

\subsubsection{Execução do projeto do refletor}

O projeto do refletor ótico é feito pelo diagrama de fluxo. O procedimento começa com a determinação da diferença entre o fluxo fornecido diretamente pela fonte e o fluxo requerido para dar a distribuição da intensidade luminosa nominal. O refletor é gerado determinando-se a forma necessária para refletir a luz da fonte e compor esta diferença.

Seguem abaixo as etapas:

$1^{\text {a) }}$ O ponto da fonte é situado na origem. Ângulos descrevem as intensidades ou o fluxo.

$2^{\mathrm{a})}$ Determina-se o tamanho do ângulo de abertura na parte traseira do refletor.

$3^{a}$ ) Determina-se a distribuição de intensidade luminosa disponível, I s ( $\alpha$ ) da fonte.

$4^{a}$ ) Determina-se a distribuição de intensidade luminosa nominal $I^{\prime}$ $(\beta)$ da luminária, incluindo o ângulo de interrupção, $\Theta$.

5a) Calcula-se a distribuição do fluxo (da fonte) disponível da fonte, $\varphi s(\alpha)$, usando as intensidades luminosas da fonte e o ângulo sólido.

6a) Calcula-se a distribuição nominal do fluxo.

$7^{a}$ ) Calcula-se o fluxo fornecido pela fonte após o redirecionamento feito pelo refletor.

\subsection{Fontes luminosas artificiais}

Dividimos basicamente as fontes artificiais de luz em cinco tipos: lâmpadas de filamento, incandescentes e halógenas, lâmpadas de descarga a baixa pressão, lâmpadas de descarga a alta pressão e os LEDs, Light Emmiting Diode, ou diodos emissores de luz. 


\subsubsection{Lâmpadas de filamento incandescente e halógena}

Efetivamente, a primeira fonte de luz artificial usada na iluminação de interiores e exteriores foi a lâmpada incandescente. Seu princípio de funcionamento consiste em fazer com que passe uma corrente elétrica através de um filamento de tungstênio.

A corrente elétrica, fluindo através do fino fio do filamento, aquece-o quase que instantaneamente, até a temperatura de sua incandescência. $O$ filamento rapidamente queima se o ar estiver presente. Assim, ele é envolvido por um bulbo de vidro, do qual é retirado o ar e preenchido com uma quantidade de gás inerte à baixa pressão, usualmente o argônio ou nitrogênio (às vezes, o criptônio). A presença do gás retarda a taxa de evaporação do filamento, o qual é espiralado para operar em temperaturas mais altas.

É importante salientar que seu princípio simples e sua pouca complexidade construtiva não conferem às lâmpadas incandescentes uma grande eficiência luminosa, permitindo níveis não superiores a $15 \mathrm{~lm} / \mathrm{W}$ (OSRAM, 2011a).

Embora ainda hoje largamente utilizadas em aplicações residenciais e uma série de outros usos, as lâmpadas incandescentes terão sua comercialização reduzida nos próximos anos, em virtude de uma portaria governamental que fixa limites mínimos de eficiência e também datas para o fim da comercialização de lâmpadas com baixa eficiência (BRASIL, 2010). Isso atinge diretamente as lâmpadas incandescentes, pois esta tecnologia tem índices de eficiência luminosa abaixo nos mínimos exigidos pela portaria.

As lâmpadas incandescentes foram insuperáveis por cerca de meio século, até o advento das lâmpadas fluorescentes e de descarga mais eficientes. Contudo, nos anos 60 as lâmpadas incandescentes tiveram uma significativa melhoria com o aparecimento das lâmpadas halógenas.

Para a obtenção de melhorias na eficiência luminosa, foi inserida uma evolução tecnológica: a utilização de um gás halógeno implantado dentro do bulbo da lâmpada. Devido às propriedades químicas dos elementos halógenos, após o desprendimento das partículas de tungstênio do filamento, essas partículas reagem com o halogênio, retornando ao 
filamento, proporcionando um fenômeno de "regeneração do filamento". O resultado desse "fenômeno" permite uma sobrevida ao filamento (e, consequentemente, à lâmpada) e também um aumento no nível de corrente suportável pelo filamento, o que traz mais luz e aumento da eficiência da lâmpada.

Ao mesmo tempo em que a sua eficiência pôde chegar a 25 lumens por watt (OSRAM, 2011a), outras vantagens foram obtidas, aumentando a duração para três a quatro vezes mais que as lâmpadas incandescentes, com $50 \%$ mais de brilho na emissão de luz.

\subsubsection{Lâmpadas de descarga}

Nas lâmpadas de descarga, a luz é produzida por meio da radiação emitida pela descarga elétrica de uma mistura gasosa composta de gás(es) inerte(s) e vapor(es) metálico(s). A mistura gasosa encontra-se confinada em um invólucro translúcido (tubo de descarga), em cujas extremidades estão inseridos eletrodos (hastes metálicas ou filamentos) que formam a interface entre a descarga e o circuito elétrico de alimentação (WAYMOUTH, 1980).

Ao contrário da lâmpada incandescente, na qual o filamento metálico é um condutor elétrico, na lâmpada de descarga o composto metálico, que é o responsável pela emissão de radiação, se encontra em estado sólido ou líquido na temperatura ambiente, e o gás inerte no interior do tubo (conhecido como gás de enchimento, ou "filling gas") é o isolante. Portanto, inicialmente é necessário um processo de ignição para o rompimento da rigidez dielétrica da coluna gasosa.

O calor gerado pela descarga através do gás inerte nos instantes iniciais, após a partida da lâmpada, vaporiza o composto metálico (GOUVÊA, 2005), gerando a luz.

Após a partida, a lâmpada de descarga apresenta uma impedância dinâmica (derivada da tensão em relação à corrente) negativa; à medida que a corrente na lâmpada aumenta a diferença de potencial entre os seus terminais diminui. Portanto, toda lâmpada de descarga necessita de um elemento com impedância positiva ligada em série para estabilizar a corrente no ponto de operação nominal da lâmpada, ou seja, de um reator. 
Figura 44 - Família de lâmpadas de descarga

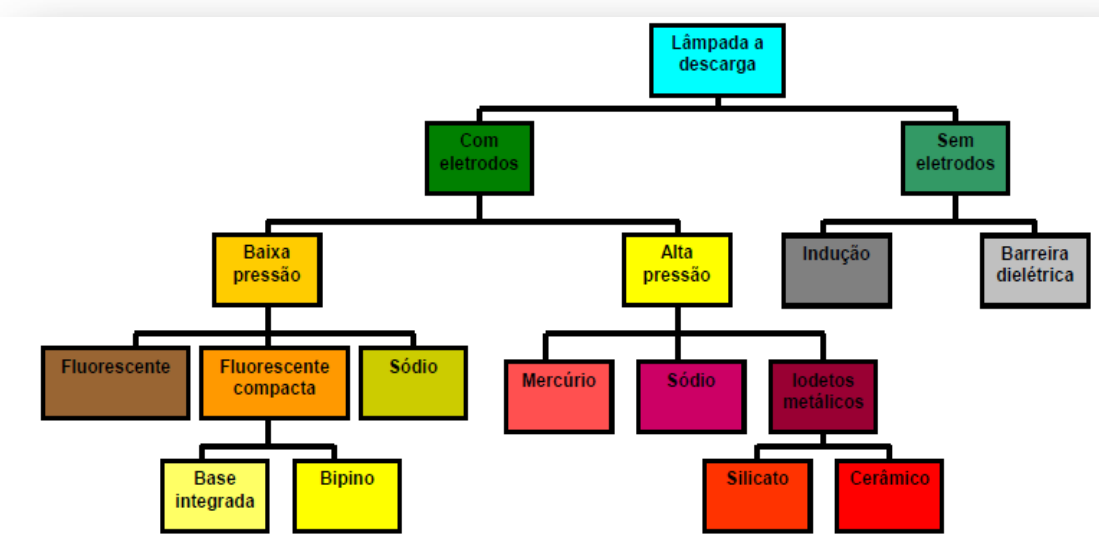

Fonte: KAISER, 2010.

As lâmpadas de descarga são classificadas pela pressão no interior do tubo (com a lâmpada em operação) em de baixa pressão e de alta pressão, conforme exemplificado na tabela 17.

Tabela 17- Descarga elétrica e pressão interna da lâmpada.

\begin{tabular}{|l|c|c|}
\hline \multirow{2}{*}{\multicolumn{1}{|c|}{ Características }} & \multicolumn{2}{c|}{ Descarga } \\
\cline { 2 - 3 } & Baixa pressão & Alta pressão \\
\hline $\begin{array}{l}\text { Pressão parcial do vapor } \\
\text { metálico }\end{array}$ & $10^{-5} \mathrm{a} 10^{-4} \mathrm{~atm}$ & $0,1 \mathrm{a} 10 \mathrm{~atm}$ \\
\hline Potência do arco & $0,5 \mathrm{a} 2 \mathrm{~W} / \mathrm{cm}$ & $200 \mathrm{a} 200 \mathrm{~W} / \mathrm{cm}$ \\
\hline Espectro & bandas & bandas + contínuo \\
\hline $\begin{array}{l}\text { Temperatura média da } \\
\text { descarga }\end{array}$ & baixa $\left(\mathrm{T}_{\text {parede }} 40^{\circ} \mathrm{C}\right)$ & $\begin{array}{c}\text { alta( } \mathrm{n}^{\circ} \text { de colisões } \\
\text { elevado })\end{array}$ \\
\hline $\begin{array}{l}\text { Tubo de descarga (diâmetro } \mathrm{x} \\
\text { comprimento) }\end{array}$ & $\mathrm{cm}(\mathrm{s}) \times \mathrm{m}(\mathrm{s})$ & mm (s) $\mathrm{x}$ cm(s) \\
\hline Eletrodos & filamentos & bastão irradiador \\
\hline
\end{tabular}

Fonte: KAISER, 2010. 


\subsubsection{Lâmpadas de descarga de baixa pressão - fluorescentes tubulares}

As lâmpadas de descarga de baixa pressão apresentam como características a pressão dos vapores metálicos na ordem de $10^{-4}$ a $10^{-5}$ atmosfera; a potência variando entre $0,5 \mathrm{~W} / \mathrm{cm}$ e $2 \mathrm{~W} / \mathrm{cm}$; eletrodos em forma de filamentos; espectro da radiação caracterizado por bandas; tubo de descarga com diâmetro entre 16 mm (T5), diâmetro de 26 mm (T8), diâmetro de 33,3 mm (T10) e aproximadamente 38 mm (T12), e comprimento variando entre $36 \mathrm{~cm}$ a, aproximadamente, 2,40m para as lâmpadas atualmente fabricadas.

Elétrons emitidos na região catódica adquirem energia cinética quando acelerados pela diferença de potencial entre filamentos. Colisões com átomos de $\mathrm{Hg}$ liberam radiação ressonante UV que excita 0 revestimento de fósforo emitindo radiação visível. A Figura 45 mostra 0 processo de transformação do UV em radiação visível.

Figura 45 - Funcionamento da lâmpada fluorescente tubular

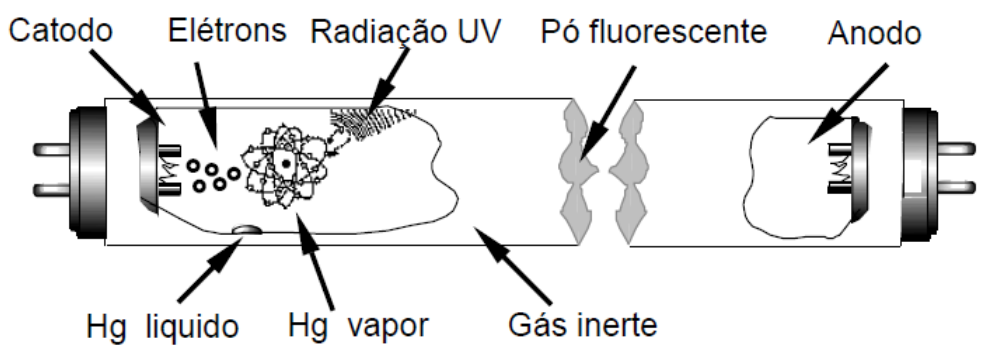

Fonte: KAISER, 2010.

Estas lâmpadas vêm passando por evoluções durante as últimas décadas, se tornando cada vez mais eficientes energeticamente, devido à evolução do pó fluorescente existente no interior do bulbo. As características colorimétricas (temperatura de cor correlata, reprodução de cores) e a eficácia da lâmpada fluorescente são determinadas pela composição e espessura do pó fluorescente ("fósforo"). Os "fósforos" são compostos que emitem luz por fluorescência quando expostos à radiação ultravioleta.

São fabricados a partir de substâncias de elevada pureza, cuja estrutura cristalina é modificada pela adição de ativadores, que determinam a 
distribuição espectral da radiação emitida. A evolução surgiu com a substituição dos fósforos, materiais orgânicos que convertem radiação UV em visível.

Até a década de 80 , utilizávamos os fósforos comuns conhecidos como halofosfatos: halophosphate, phosphors $\left[\mathrm{Ca}_{5}\left(\mathrm{PO}_{4}\right)_{3}(\mathrm{~F}, \mathrm{Cl}): \mathrm{Sb}^{3}+, \mathrm{Mn}^{2}+\right]$.

A eficiência luminosa destas lâmpadas era de $40 \mathrm{~lm} / \mathrm{W}$ a $60 \mathrm{~lm} / \mathrm{W}$, e o Índice de reprodução de cores na ordem de 50 a 70 Ra.

Foram desenvolvidos diferentes halofosfatos, cobrindo as diferentes regiões do espectro, com a obtenção de elevada reprodução de cores $\mathrm{Ra}$ =93 a 98; porém, com redução de eficiência luminosa (até 30\%, dependendo da potência).

Nesta mesma década as indústrias passaram a utilizar uma combinação entre o trifósforo (combinação de três fósforos que emitem radiação em uma banda estreita do espectro, reproduzindo as três cores primárias da $\mathrm{CIE}$ ) e camadas finas de halofosfato tradicional. O aumento de eficácia luminosa foi de $12 \%$ a $15 \%$ em relação a lâmpadas com halofosfato, e IRC=85 Ra. Devido à banda estreita, os picos são elevados e lâmpada tem alta eficiência.

Figura 46 - Combinação halofosfato e trifosforo no revestimento das lâmpadas fluorescentes

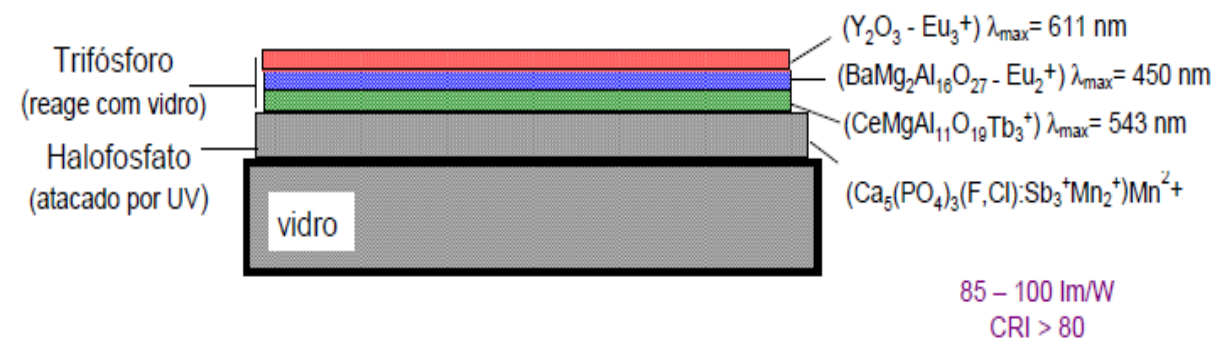

Fonte: KAISER, 2010.

Com a combinação entre os fósforos, o projetista de iluminação tem à disposição não somente a escolha da fonte de luz, como também uma ampla gama de variações de temperaturas de cor correlata, exemplificada na Tabela 18 a seguir, conforme a necessidade do projeto e das aplicações: $2700 \mathrm{~K}, 3000 \mathrm{~K}, 4000 \mathrm{~K} \mathrm{~K}, 5000 \mathrm{~K}, 6500 \mathrm{~K}$ e $8000 \mathrm{~K}$. 
Tabela 18 - Temperaturas de cor correlata (Tcp)

\begin{tabular}{|l|l|}
\hline Aparência da cor & Temperatura de cor correlata \\
\hline Quente & Abaixo de $3300 \mathrm{~K}$ \\
\hline Neutra & $3300 \mathrm{~K}$ a $5300 \mathrm{~K}$ \\
\hline Fria & Acima de $5300 \mathrm{~K}$ \\
\hline
\end{tabular}

Fonte: Norma NBR ISO 8995-1: lluminação de ambientes de trabalho (futura Norma aprovada e em fase de publicação).

Com a combinação dos pós de halofosfato e trifosforo, foi possível a redução dos diâmetros dos bulbos das lâmpadas. A necessidade de menores quantidades de mercúrio, por sua vez, possibilitou maiores rendimentos do sistema, uma vez que bulbos com menores diâmetros possibilitam maior reflexão do fluxo luminoso, conforme ilustrado na figura 47.

Figura 47 - Representação da reflexão da luz com a redução do diâmetro do tubo das lâmpadas - T12 - 36 mm, T10 - 33,3 mm, T8 - 26 mm e T5 -16 mm

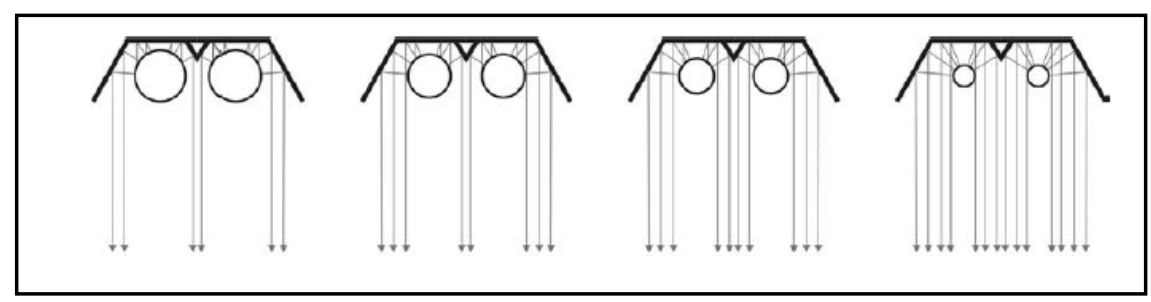

Fonte: PHILIPS, 2000.

\subsection{Lâmpada fluorescente tubular T5 HE}

As lâmpadas T5 representam a maior tecnologia em lâmpadas fluorescentes tubulares. Com um diâmetro de tubo de apenas $16 \mathrm{~mm}$, permitem que as luminárias se tornem ainda mais compactas do que as luminárias com "lâmpadas padrão", de diâmetro de tubo igual a 36 mm (T12), 33,3 mm (T10) e $26 \mathrm{~mm}$ (T8).

O mercado disponibiliza duas principais versões de lâmpadas fluorescentes tubulares T5: 
Fluorescente Tubular T5 HE (High Efficiency) - Alta Eficiência particularmente econômica, com eficiência energética de até 104 Im/W, representa até $20 \%$ de economia em relação ao sistema T8 e até $40 \%$ em relação aos T10/T12, além de apresentar apenas 8\% de depreciação do fluxo luminoso ao final de sua vida útil. Em conjunto com o reator eletrônico, permitem sistemas de iluminação mais modernos e compactos, além de proporcionarem significativa economia de energia com conforto, versatilidade, praticidade e segurança para as instalações.

Tabela 19 - Características das lâmpadas fluorescentes T5 HE.

\begin{tabular}{|c|c|c|c|c|c|c|c|}
\hline & $W$ & $\operatorname{lm}_{35^{\circ} \mathrm{C}}$ & & IRC & $\theta_{\mathrm{d}[\mathrm{mm}]}$ & $\frac{1}{[\mathrm{~mm}]}$ & $\approx$ \\
\hline & Potência & Fluxo Luminso & Temp. de Cor & holice de reprod. & Diâmetro & Comprimento & Base \\
\hline \multicolumn{8}{|c|}{ LUMILUX® T5 HE - Fluorescente tubular de alta eficiência } \\
\hline HE $14 W / 830$ & 14 & 1350 & 3000 & $80-89$ & 16 & 549 & G5 \\
\hline HE $14 W / 840$ & 14 & 1350 & 4000 & $80-89$ & 16 & 549 & G5 \\
\hline HE $14 W / 850$ & 14 & 1300 & 5000 & $80-89$ & 16 & 549 & G5 \\
\hline HE 21W/830 & 21 & 2100 & 3000 & $80-89$ & 16 & 849 & G5 \\
\hline HE 21W/840 & 21 & 2100 & 4000 & $80-89$ & 16 & 849 & G5 \\
\hline HE 28W/830 & 28 & 2900 & 3000 & $80-89$ & 16 & 1149 & G5 \\
\hline HE 28W/840 & 28 & 2900 & 4000 & $80-89$ & 16 & 1149 & G5 \\
\hline HE 28W/850 & 28 & 2750 & 5000 & $80-89$ & 16 & 1149 & G5 \\
\hline HE 35W/830 & 35 & 3650 & 3000 & $80-89$ & 16 & 1449 & G5 \\
\hline HE 35W/840 & 35 & 3650 & 4000 & $80-89$ & 16 & 1449 & G5 \\
\hline
\end{tabular}

Fonte: OSRAM, 2012.

Fluorescente Tubular T5 HO (High Output) - Alto fluxo luminoso - é possível obter um elevado "pacote de luz", ou seja, até 50\% mais luz quando comparado à linha T8, de mesmo comprimento. Ideal, portanto, para aplicações com pé-direito elevado ou com iluminação indireta. 
Tabela 20 - Características das lâmpadas fluorescentes T5 HO

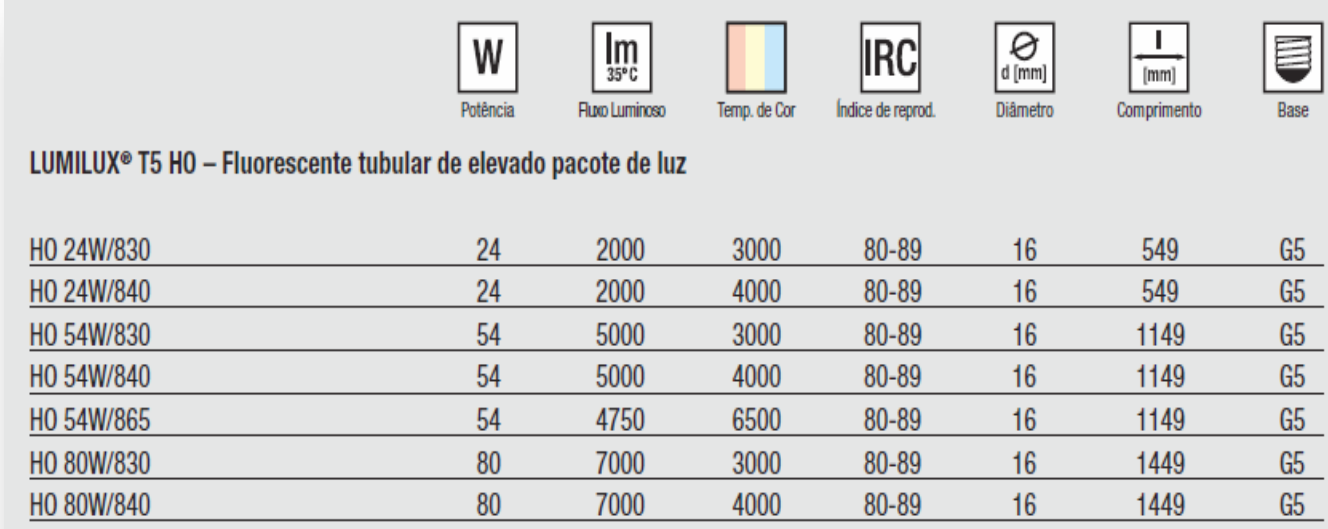

Fonte: OSRAM, 2012.

Para fazer com que sistemas de iluminação para lâmpadas de descarga funcionem, muitas vezes se torna necessário o uso de alguns equipamentos auxiliares, como transformadores reatores e ignitores ${ }^{18}$.

Com a evolução da tecnologia nas últimas décadas, os equipamentos auxiliares estão mais eficientes, consomem menos energia, têm uma maior durabilidade e passaram também a colaborar para que as lâmpadas tenham um incremento na sua vida útil.

As lâmpadas fluorescentes tubulares de tubo $\mathrm{T} 12^{19}$ ou $\mathrm{T} 10^{20}$, com pó fluorescente halofosfato ${ }^{21}$, têm uma depreciação aproximada de 0,80 após 7.500 horas de uso. (ROIZENBLATT, SMIT, 1989). Com a evolução e incremento tecnológico ao longo dos anos, os fabricantes trocaram o pó fluorescente halofosfato pelo pó trifósforo ${ }^{22}$, hoje empregado nas lâmpadas fluorescentes tubulares de tubo $\mathrm{T}^{23}$ e $T 5^{24}$. A depreciação do fluxo luminoso

\footnotetext{
${ }^{18}$ Ignitores - componentes que têm por função gerar picos de tensão para o acendimento da lâmpada de descarga de alta pressão.

19 Tubo T12 - Refere-se ao diâmetro $38,0 \mathrm{~mm}$ do tubo da fluorescente tubular.

20 Tubo T10 - Refere-se ao diâmetro $33,3 \mathrm{~mm}$ do tubo da fluorescente tubular.

${ }^{21}$ Halofosfato - Recobrimento da superfície interna da lâmpada com fósforo comum: Halophosphate, phosphors $\left[\mathrm{Ca}_{5}\left(\mathrm{PO}_{4}\right)_{3}(\mathrm{~F}, \mathrm{Cl}): \mathrm{Sb}^{3}+, \mathrm{Mn}^{2}+\right]$.

${ }^{22}$ Trifósforo - Recobrimento da superfície interna da lâmpada, pela combinação de três fósforos que emitem radiação em uma banda estreita do espectro, reproduzindo as três cores primárias da CIE-Comission International de l'Éclairage.

${ }^{23}$ Tubo T8 - Refere-se ao diâmetro $26,0 \mathrm{~mm}$ do tubo da fluorescente tubular.

${ }^{24}$ Tubo T5 - Refere-se ao diâmetro $16,0 \mathrm{~mm}$ do tubo da fluorescente tubular.
} 
do sistema de tubo T8 é aproximadamente de 0,85 após 7.500 horas de uso, e, para as lâmpadas fluorescentes tubulares de tubo T5, de aproximadamente 0,99 para 7.500 horas de uso, 0,90 para 16.000 horas, e 0,50 para 20.000 horas de uso, bem menor que a tecnologia anterior.

A tecnologia do pó trifósforo também permitiu o incremento da eficiência luminosa das lâmpadas, melhor reprodução de cores, redução do diâmetro do bulbo e, consequentemente, redução da quantidade de mercúrio presente em cada lâmpada, no caso específico da lâmpada fluorescente tubular T5, com aproximadamente 1,5 a 1,9 mg de mercúrio.

\subsubsection{Lâmpadas de descarga de alta pressão}

As lâmpadas de descarga de alta pressão, também conhecidas como lâmpadas HID (High Intensity Discharge), utilizam vapores metálicos, em geral mercúrio e/ou sódio, pressões da ordem de 1 a 10 atmosferas, e operam com uma densidade de potência de arco da ordem de 20 a 200 W/cm. A radiação emitida pela descarga apresenta uma distribuição espectral contínua, sobre a qual se encontra superposta às raias predominantes dos átomos que constituem o vapor metálico. Os eletrodos são bastões irradiadores e o tubo de descarga tem dimensões reduzidas (diâmetro de mm e comprimento de cm) (GOUVÊA, 2005).

Toda lâmpada de descarga de alta pressão precisa de um reator ou algum elemento de controle da corrente elétrica que circula pela lâmpada e de um ignitor para seu acendimento, que gera picos de tensão da ordem de $5 \mathrm{KV}$. Os reatores não geram esses picos de tensão, fato que faz com que seja necessária a utilização de ignitores.

Existem três tipos básicos de lâmpadas comerciais: vapor de mercúrio de alta pressão, sódio de alta pressão e as lâmpadas de alta pressão de vapores metálicos.

- Lâmpada de Vapor de Mercúrio - A lâmpada de vapor de mercúrio de alta pressão ou HPM (High Pressure Mercury) é constituída por um tubo de descarga transparente, de dimensões reduzidas, inserido em um bulbo de vidro, que é revestido internamente por uma camada de "fósforo" para correção do índice de reprodução de cor. Esse bulbo de vidro 
transparente, com formato ovoide ou elipsoidal, contém nitrogênio, que forma uma atmosfera protetora para reduzir a oxidação de partes metálicas, limita a intensidade da radiação ultravioleta que atinge o revestimento de "fósforo" e melhora as características de isolamento térmico.

Nos instantes iniciais da descarga, a lâmpada emite uma luz verde clara e a intensidade luminosa aumenta gradativamente, até estabilizar-se após 6 a 7 minutos, quando a luz se torna branca, mas com uma tonalidade levemente esverdeada. A luz emitida por uma lâmpada sem revestimento de fósforo apresenta um baixo índice de reprodução de cor $(\mathrm{Ra}=20)$, devido à ausência de raias vermelhas.

O "fósforo" utilizado internamente para recobrir o bulbo da lâmpada serve para melhorar significativamente o índice de reprodução $(R a=50)$ (GOUVÊA, 2005).

A tensão de ignição da lâmpada aumenta com a pressão de vapor de mercúrio, ou seja, com a temperatura do tubo de descarga. Quando se desliga uma lâmpada alimentada por um reator indutivo convencional, a sua nova ignição só é possível após 3 a 5 minutos, que é o intervalo de tempo necessário para o esfriamento da lâmpada e consequente queda de pressão.

A lâmpada de mercúrio apresenta fluxo luminoso elevado e vida útil longa; porém, a sua eficácia luminosa é relativamente baixa. Ela está atualmente sendo substituída por lâmpadas mais eficientes, como lâmpadas de vapor de sódio - para o caso de iluminação pública - e lâmpadas de vapor metálico - para iluminação de indústrias têxteis, gráficas e montadoras de automóveis.

- Lâmpada Vapor de Sódio - A lâmpada de vapor de sódio de alta pressão HPS (High Pressure Sodium) é constituída por um tubo de descarga cilíndrico e translúcido, com um eletrodo em cada extremidade. Este tubo é sustentado por uma estrutura mecânica, sob vácuo, no interior em um bulbo de vidro borosilicado, com formato ovóide ou cilíndrico (GOUVÊA, 2005). As lâmpadas a vapor de sódio, além de possuírem mercúrio como elemento principal, possui o sódio. Essa alteração permite a emissão de energia eletromagnética dentro do espectro de radiação visível 
da luz de 380 a $780 \mathrm{~nm}^{25}$ diretamente (faixa visível do espectro - luz), não havendo necessidade de elementos conversores de ultravioleta em luz. Como benefícios resultantes, a eficiência das lâmpadas a vapor de sódio é maior do que as lâmpadas a vapor de mercúrio, atingindo (dependendo da potência da lâmpada) eficiências de 70 a 150lm/W (OSRAM, 2011a).

Um fator que favorece a aplicação das lâmpadas a vapor de sódio está na sua grande expectativa de vida útil, podendo chegar a $32.000 \mathrm{~h}$ (OSRAM, 2011b), o que permite sistemas ainda mais eficientes e menos onerosos do ponto de vista de sua manutenção.

A lâmpada de vapor de sódio convencional apresenta, em geral, um baixo índice de reprodução de cor $(\mathrm{Ra}<25)$, mas tem elevada eficácia luminosa (120 Im/W para a lâmpada de $400 \mathrm{~W}$ ) e vida útil longa (24.000 horas). No entanto, existem lâmpadas especiais que apresentam um elevado índice de reprodução de cor $(\mathrm{Ra}=85)$, porém com baixa eficácia luminosa, de cerca de $80 \mathrm{Im} / \mathrm{W}$.

- Lâmpada Vapor Metálico - A lâmpada de vapor metálico HPMH (High Pressure Metal Halide) é construtivamente semelhante à lâmpada de mercúrio de alta pressão, ou seja, utiliza um tubo de descarga de sílica fundida inserido no interior de um bulbo de quartzo transparente. Este tubo contém vapor de mercúrio (que é o gás de ignição) e mais um coquetel de metais (sódio, tálio, índio, disprosium, zinco). A temperatura de vaporização dos metais é em geral superior à máxima temperatura suportável pelo material do tubo de descarga. Já o metal na forma de um haleto vaporiza a uma temperatura significativamente inferior. Geralmente são utilizados iodetos, que são quimicamente menos reativos. A adição de metais introduz raias no espectro que melhoram as características de reprodução de cores da lâmpada.

As lâmpadas de vapor metálico apresentam uma eficácia luminosa de 65 a $100 \mathrm{~lm} / \mathrm{W}$ e um índice de reprodução de cores superior a Ra 80. A sua vida útil atualmente chega a $15.000 \mathrm{~h}$. Existem diversos modelos com vida útil de apenas $6.000 \mathrm{~h}$, mas estas são de uso especial.

\footnotetext{
${ }^{25}$ Nanômetro - Submúltiplo do metro, igual a 10-9m; milimícron.
} 


\subsubsection{Tecnologia LED}

LED, sigla em inglês de Light Emmiting Diode ou diodo emissor de luz, representa uma tecnologia emergente que está começando a trazer impactos significativos em vários setores da economia.

As indústrias de iluminação, automotiva, sinalização, médica e eletrônica, entre outras, se aperceberam das vantagens de utilizar os pequenos diodos, também chamados de "iluminação em estado sólido" ou SSL (Solid State Lighting), devido à ausência de filamentos ou gases - mas com um pequeno chip semicondutor eletroluminescente - que emite a luz na presença da corrente elétrica.

Apesar dos LEDs existirem há várias décadas, somente nos últimos dez anos houve a viabilização técnica nos materiais semicondutores e nos encapsulamentos. Este fato veio proporcionar potência, eficiência luminosa e vida útil maiores.

Com a expectativa de economia de energia que os LEDs irão proporcionar nos próximos anos, os governos dos países que os produzem têm subsidiado diversas pesquisas em tecnologia, de forma a viabilizar economicamente seus benefícios para o mercado.

O LED é um diodo semicondutor, e como referência, dizemos que o diodo é um componente eletrônico, amplamente utilizado em equipamentos eletrônicos, que permite a passagem da corrente elétrica em uma direção apenas.

A diferença é que o LED, quando energizado, emite luz visível, que é monocromática e produzida pelas interações energéticas do elétron dentro da substância semicondutora. O processo de emissão de luz pela aplicação de uma fonte de energia elétrica é chamado de eletroluminescência.

Em um chip de material semicondutor, tratado para criar uma estrutura chamada junção P-N, ao aplicarmos a corrente elétrica, ocorrem recombinações de lacunas e elétrons. Essa recombinação exige que a energia possuída por esse elétron, que até então era livre, seja liberada, o que acontece na forma de calor ou fótons de luz. 
Figura 48 - Processo de emissão de luz de um LED

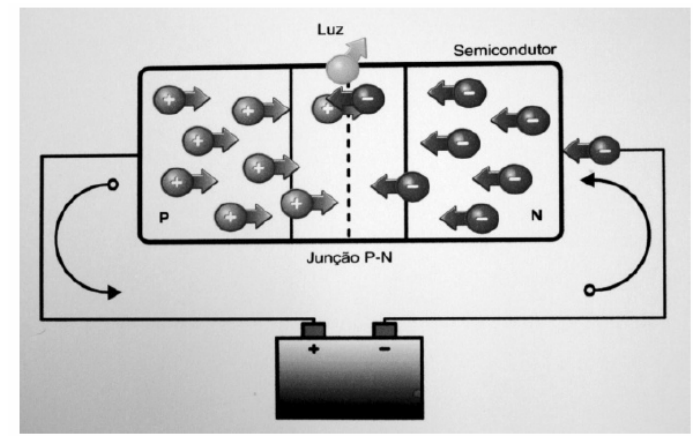

Fonte: PINTO,2008.

No silício e no germânio, que são os elementos semicondutores básicos dos diodos, transistores e chips de computador, a maior parte da energia é liberada na forma de calor, sendo insignificante a luz emitida, isto devido à opacidade do material.

LED vermelho ou âmbar - Alumínio, Índio, Gálio e Fósforo (AllnGaP)

LED azul ou verde - Índio, Gálio e Nitrogênio (InGaN)

LED branco - LED azul com adição de Fósforo amarelo

\subsubsection{Eficiência energética das lâmpadas}

A eficiência das fontes luminosas artificiais aplicadas à iluminação de interiores, e seu aprimoramento ao longo dos anos, é exemplificado na Figura 49, na qual relaciona cada modelo de lâmpada às suas eficiências luminosas, permitindo mostrar claramente um aumento na eficiência luminosa das fontes de tecnologias mais modernas e uma maior vida útil, que vem favorecer ainda mais a sua aplicação. 
Figura 49 - Indicação das eficiências luminosas em função do tipo de lâmpada.

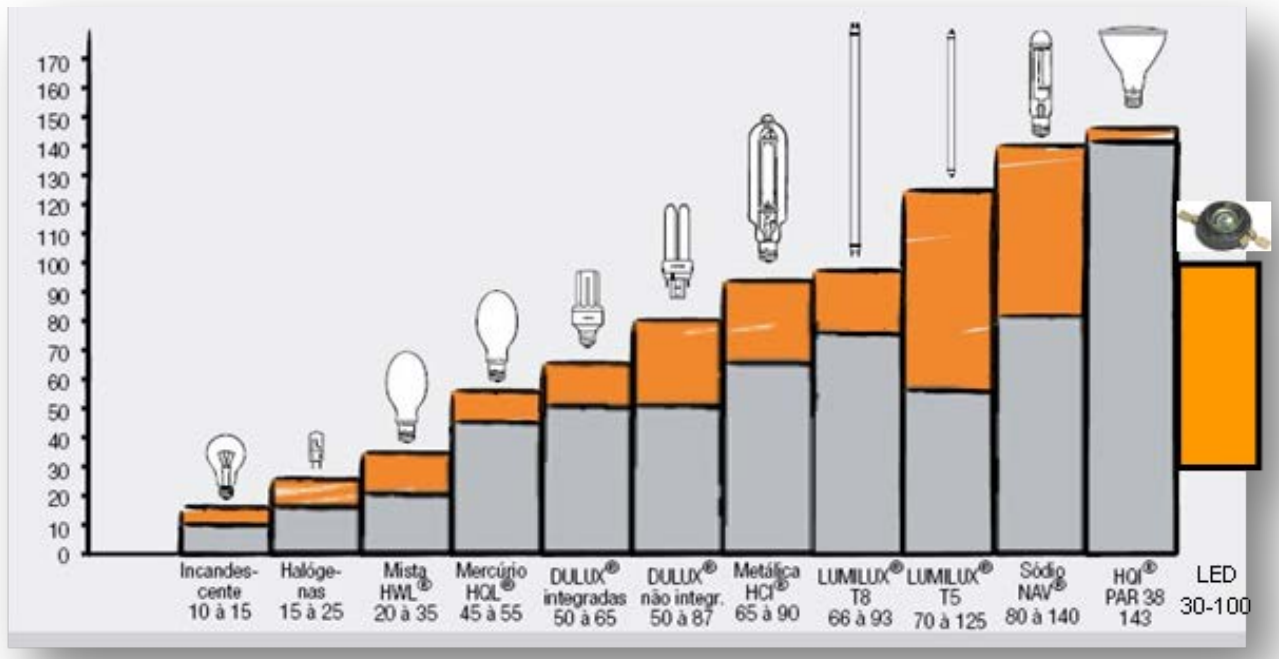

Fonte: JACOB, 2009, OSRAM 2011.

\subsection{Equipamentos auxiliares}

Os reatores são equipamentos que fazem parte dos componentes elétricos das luminárias, e são importantes para o desempenho elétrico do conjunto.

Os reatores, segundo a ABNT (1991), são dispositivos com a finalidade de limitar a corrente da(s) lâmpada(s), tanto na partida como em funcionamento a valores preestabelecidos. São ligados entre a fonte de alimentação e uma ou mais lâmpadas de descarga, podendo ser classificados em dois tipos principais: eletromagnéticos e eletrônicos.

\subsubsection{Reatores eletromagnéticos}

O modelo mais tradicional é o eletromagnético e sua construção basicamente composta por um enrolamento envolvido por um núcleo de baixa relutância, que eleva o fluxo magnético a um valor suficiente para controlar a corrente elétrica (LOPES, 2002).

Os reatores eletromagnéticos são constituídos por um núcleo laminado de aço silício (com baixas perdas) e bobinas de fio de cobre esmaltado. São impregnados com resina de poliéster, adicionado com carga 
mineral, tendo um grande poder de isolação e dissipação térmica. (Philips, 2004a).

Operam em frequência industrial $(60 \mathrm{~Hz})$ e possuem elevada vida útil, em muitos casos superior a 10 anos. São equipamentos robustos, pesados e sensíveis a variações de tensão e temperatura ambiente.

Os reatores são divididos em alto fator de potência (AFP) e baixo fator de potência (BFP). Basicamente, o fator de potência é considerado como sendo o cosseno da defasagem entre corrente e tensão num circuito. Dessa forma, em circuitos não puramente resistivos (onde a defasagem entre tensão e corrente é zero), pode ocorrer tal defasagem, o que faz com que uma parte da potência fornecida ao sistema não seja aproveitada para realização de trabalho, mas perdida em forma de potência reativa (indutiva). Assim, há que se utilizarem componentes que minimizem essa potência aparente. O capacitor corrige o fator de potência (cosseno $\phi$ entre a potência aparente e a potência ativa de um circuito).

A forma como se apresenta a distribuição das potências geradas em um circuito é apresentada na Figura 50.

Figura 50 - Representação gráfica das potências envolvidas em um circuito não resistivo.

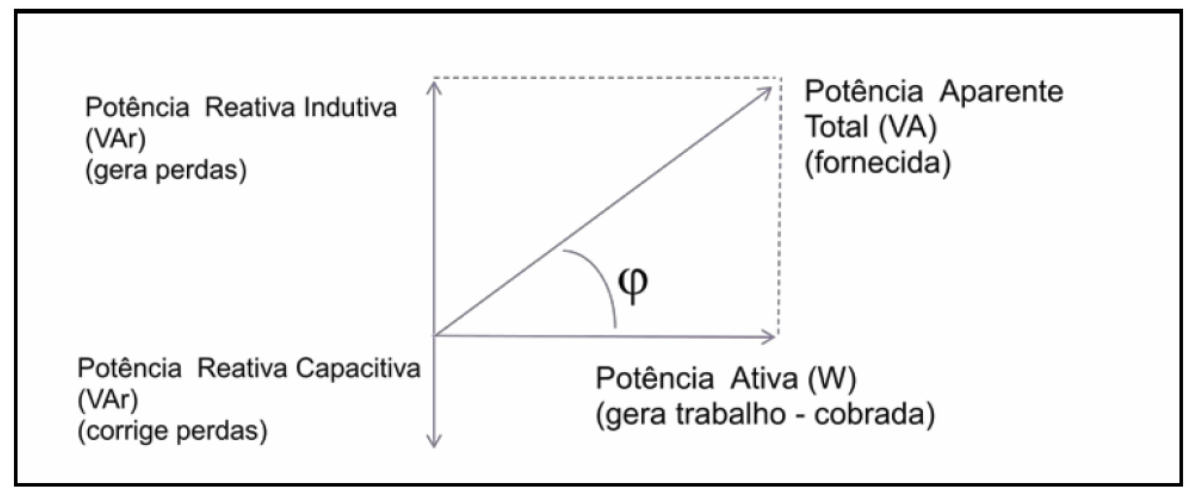

Fonte: NISKIER, MACINTYRE,1992.

A utilização de capacitores tem por finalidade minimizar essa potência reativa (através de uma carga capacitiva). Por convenção, no Brasil adota-se como um equipamento Alto Fator de Potência (AFP) aquele que possui cosseno $\phi$ (ângulo entre tensão e corrente) superior a 0,92 (ANEEL, 
2000), sendo que circuitos onde o cosseno $\phi$ é menor que 0,92 são chamados de Baixo Fator de Potência (BFP).

Os reatores AFP possuem internamente capacitores que fazem a correção do fator de potência. Já aqueles BFP necessitam de capacitores externos para fazer essa correção. Esses capacitores externos são outros equipamentos auxiliares considerados nos sistemas de iluminação pública. Uma ressalva que se faz diz respeito à Portaria 454 do Inmetro, que determina que a partir de $1^{\circ}$ de janeiro de 2013 todos os reatores para lâmpadas de descarga comercializados no Brasil deverão ser AFP (Inmetro, 2010).

\subsubsection{Ignitor}

Algumas lâmpadas de descarga de alta presão (como as lâmpadas a vapor de sódio e as de multivapores metálicos) necessitam para seu acendimento de picos de tensão da ordem de 5KV; já as lâmpadas de baixa pressão (com as fluorescentes tubulares, circulares e compactas) necessitam para o seu acendimento de picos de $800 \mathrm{~V}$. Os reatores não geram esses picos de tensão, fato que faz necessária a utilização de ignitores. Estes componentes têm por função gerar esses picos de tensão para o acendimento da lâmpada. Importante salientar que, uma vez que a lâmpada esteja em regime, já com seu fluxo luminoso total, estes equipamentos deixam de gerar pulsos de tensão.

\subsubsection{Reatores eletrônicos}

Reatores eletrônicos são inversores C.A./C.A., alimentados pela rede, que incluem os elementos necessários para a partida e funcionamento de uma ou mais lâmpadas fluorescentes (ABNT, 1999b).

São constituídos por componentes eletrônicos, entre eles capacitores, indutores, resistores e circuitos integrados, entre outros. Os reatores eletrônicos são alimentados em frequência de rede de $60 \mathrm{~Hz}$; porém, operam em altas frequências: de $20 \mathrm{kHz}$ a $50 \mathrm{kHz}$, que propiciam maior fluxo luminoso com menor consumo de energia. 
Reatores eletrônicos são constituídos por capacitores e indutores para alta frequência, resistores, circuitos integrados e outros componentes eletrônicos. Operam em alta frequência (de $20 \mathrm{kHz}$ a $50 \mathrm{kHz}$ ). Essa faixa de operação, quando bem projetada, proporciona maior fluxo luminoso com menor potência, o que transforma os reatores eletrônicos em produtos que economizam energia $(30 \%$ menor, se comparados a reatores eletromagnéticos [OSRAM, 2007]) e operam com maior eficiência (PHILIPS, 2004). Toda lâmpada fluorescente atuam com maior eficiência luminosa em frequências superiores a $15 \mathrm{kHz}$. Desta forma, lâmpadas fluorescentes de $1,2 \mathrm{~m}$ operam com eficiência aproximadamente $10 \%$ maior, enquanto fluorescentes de 2,4m melhoram a eficiência em 5\% (GE, 2002). Como estes reatores regeneram o arco elétrico mais de 40.000 vezes por segundo, tempo curto demais para que se perceba visualmente esta variação, não existe o problema de efeito estroboscópio.

Os reatores são classificados por tipo de partida e princípio de funcionamento:

- Reator eletromagnético de partida convencional: fornece por alguns segundos uma tensão nos filamentos da lâmpada para preaquecê-lo e, em seguida, com a utilização de um iniciador (starter), proporciona o acendimento da lâmpada fluorescente;

- Reator eletromagnético de partida rápida: os filamentos são aquecidos constantemente pelo reator, o que facilita o acendimento da lâmpada em um curto espaço de tempo. Para este tipo de partida não é utilizado o starter, mas sim uma luminária (chapa metálica) aterrada é necessária para o perfeito funcionamento das lâmpadas;

- Reator eletrônico de partida rápida: o acendimento é controlado eletronicamente pelo sistema de preaquecimento dos filamentos da lâmpada. O reator gera uma pequena tensão em cada filamento e, em seguida, uma tensão de circuito aberto entre os extremos da lâmpada. Esta partida possibilita a emissão de elétrons por efeito termiônicos. O tempo entre a energização do reator e o acendimento da lâmpada ocorre em torno de 1" a 2,5"; 
- Reator eletrônico de partida instantânea: não há preaquecimento dos filamentos. O reator gera diretamente a tensão de circuito aberto para o acendimento da lâmpada;

- Reator eletrônico de partida programada: consiste na combinação das duas partidas anteriores, onde o reator controla além dos valores de tensão, o tempo de preaquecimento da lâmpada, fornecendo em seguida à tensão de circuito aberto e posterior acendimento.

- Os reatores eletrônicos, quando comparados aos reatores eletromagnéticos, possuem diversas vantagens, como:

- Operação mais eficiente da lâmpada em função do aumento da frequência de operação (economia de até $30 \%$ para o mesmo fluxo luminoso);

- Menor custo de operação em sistemas de iluminação e ar condicionado;

- Ausência do efeito flicker (cintilação);

- Ausência do efeito estroboscópico;

- Facilidade de instalação e manutenção, por serem mais leves;

- Ausência de ruído audível; e

- Permitem dimerizar o fluxo luminoso das lâmpadas.

Importantes características que diferenciam os reatores eletrônicos são a distorção harmônica THD e o fator de fluxo luminoso do reator FFL; a distorção Harmônica THD (Total Harmonic Distortion) é a interferência gerada na rede elétrica pelos harmônicos de alta frequência de qualquer equipamento, principalmente os eletrônicos. A norma IEC determina que um reator seja aceito com distorção harmônica menor ou igual a 32\%.

E o fator de fluxo luminoso (FFL), ou ballast factor (BF), é a relação entre o fluxo obtido na lâmpada com um reator medido (desejado), e o fluxo com um reator de referência (fluxo nominal da lâmpada).

- Sistemas de Gerenciamento da iluminação - Os sistemas de gerenciamento da iluminação (LMS) têm como principal objetivo controlar os níveis de iluminância, elevar a economia do sistema e atender às 
necessidades e exigências da instalação e dos usuários, o que permite grande flexibilidade e dinamismo à iluminação.

- DALI (Digital Addressable Lighting Interface) é um padrão de interface não proprietária para reatores eletrônicos dimerizáveis, que proporciona maior funcionalidade, flexibilidade e ampla facilidade de uso. Permite a interface para todas as fontes de lâmpadas halógenas, lâmpadas fluorescentes compactas, lâmpadas fluorescentes tubulares, lâmpadas de multivapores metálicos e LEDs.

- De fácil planejamento, com um sinal de controle único em 2 fios para até 256 dispositivos, permite que os grupos de iluminação sejam atribuídos na fase de planejamento, com o auxílio de um software.

- A instalação do sinal de controle pode ser feita, inclusive, separada do fornecimento de energia. O sinal de controle é protegido contra inversão de polaridade e pode ser passado juntamente com os cabos de energia, como por exemplo, um cabo de cinco vias. O sinal de controle simplesmente tem que ser dimensionado para a tensão de linha.

- As funções de ligar e dimerizar são controladas exclusivamente por meio do sinal de controle. Como meio de detectar se a lâmpada falhou, o estado da lâmpada pode ser relatado através de um dispositivo DALI para o controlador e, em seguida, apresentada pelo controlador. Luminárias que usam interface DALI podem ser facilmente integradas a um sistema de automação predial, através de gateways (conversores de protocolo) como EIB, LON ou Ethernet (OSRAM, 2012).

- Os sensores de luz detectam o nível de iluminação, considerando a luz artificial e a natural. Assim, os grupos de luminárias podem ser controlados de acordo com sua posição no ambiente e a quantidade de luz disponível, o que permite que um nível de iluminação predefinido (de 500 lux, por exemplo) seja mantido. Os usuários ainda podem ajustar a iluminação a qualquer momento para um nível que satisfaça suas necessidades específicas.

- Caso um sensor de presença seja utilizado, a iluminação será acionada automaticamente somente quando houver alguém no ambiente, o que aumenta ainda mais o potencial de economia de energia. 
- Sensores de luz e presença fornecem a base para a economia de energia, pois permitem que a luz natural disponível seja monitorada e complementada com a luz artificial. O sistema de iluminação apenas é acionado pelo sensor de presença caso alguma pessoa esteja ou adentre o ambiente. Desta forma, a utilização de sensores permite atingir uma economia em energia de até $70 \%$.

Devido à grande quantidade de equipamentos auxiliares no mercado e para possibilitar aos usuários a comparação entre a vida útil de reatores eletrônicos, a IEC 929 (1996) recomenda que os fabricantes informem em seus catálogos: a máxima temperatura de superfície (tl) ou a máxima temperatura do componente que afeta a vida do produto; medida em condições normais de operação, que permita ao reator atingir uma vida de 50.000 horas; e a taxa de falhas, caso o reator seja operado continuamente na máxima temperatura, em unidades de falha por tempo. Em alguns países, como o Japão, isto é aplicado para uma vida de 40.000 horas. No Brasil, a NBR não estabelece recomendações semelhantes. 


\section{DADOS SEGUNDARIOS: CRRTERRIOS QUUANTITATIVOS DE DESEMMPENUIO DA ILUMMNAACARO}

\subsection{Introdução}

Segundo EPRI (1992), o desempenho de uma luminária é determinado pela sua eficiência e pelo coeficiente de utilização, sendo que os refletores e a forma da luminária são os componentes que mais influenciam a eficiência do sistema. Portanto, para a obtenção de uma luminária eficiente e que se consiga maximizar o uso da luz gerada por ela, será de grande valia eleger os melhores componentes, materiais e técnicas no processo produtivo.

\subsection{Características fotométricas}

A fotometria consiste em uma serie de métodos e processos de medida das grandezas luminosas. Para introduzir o assunto, desejamos dar uma noção dos processos comumente utilizados na determinação do fluxo luminoso, intensidade luminosa, iluminâncias, luminâncias e curvas de desempenho dos aparelhos de iluminação.

Os fotômetros são equipamentos utilizados nas medições de nível de iluminação. Os fotômetros mais antigos eram, simplesmente, aparelhos comparadores que nos permitiam avaliar visualmente uma grandeza quando comparada com um padrão (fotômetro de Bunsen, de mancha de óleo, Lummer-Brodhum, fotômetro de cintilação etc.) Os fotômetros atuais, fotoelétricos, baseiam-se em fotocélulas e, pelo fato de ser calibrados, nos permitem a leitura direta da grandeza medida (luxímetros ${ }^{26}$, luminancímetros $^{27}$ etc) (MOREIRA, 2006).A medição do fluxo luminoso utiliza uma esfera integradora ou esfera de Ulbricht $^{28}$ para a medição do fluxo luminoso emitido por uma fonte de luz. A fonte luminosa é posicionada no centro da esfera e um anteparo bloqueia a incidência de luz direta da fonte sobre um sensor de iluminância instalado numa abertura da esfera. A superfície interna apresenta um revestimento (por exemplo, óxido de

\footnotetext{
${ }^{26}$ Luxímetros - Instrumento destinado a medir iluminância.

27 Luminancímetros - Instrumento destinado a medir luminância.
} 
magnésio ou sulfato de bário) que a torna um difusor perfeito (cada ponto da superfície tem os mesmos valores de luminância e iluminância).

Desta forma, a luminância da superfície da esfera é proporcional ao fluxo luminoso, independente da distribuição da intensidade luminosa (MOREIRA, 2006).

$$
\begin{aligned}
& \phi=\overline{\mathrm{E}} \cdot \mathrm{A} \cdot \alpha=\overline{\mathrm{E}} \cdot \mathrm{A} \cdot(1-\rho) \\
& \overline{\mathrm{E}}_{\text {ind }}=\overline{\mathrm{E}}-\overline{\mathrm{E}}_{\text {dir }}=\frac{\phi}{\mathrm{A}} \cdot \frac{1}{1-\rho}-\frac{\phi}{\mathrm{A}}=\frac{\phi}{\mathrm{A}} \cdot \frac{\rho}{1-\rho}
\end{aligned}
$$

\section{Fórmula 1}

$$
\phi=\overline{\mathrm{E}}_{\text {ind }} \cdot \mathrm{A} \cdot \frac{1-\rho}{\rho}
$$

\section{Fórmula 2}

Onde:

A - Área da esfera

E - lluminamento médio da superfície interna.

$E_{\text {ind }}$ - lluminamento indireto

$\mathrm{E}_{\text {dir }}$ - lluminamento direto

p- Coeficiente de reflexão

a- Coeficiente de absorção

Figura 51 - Esfera integradora ou Esfera de Ulbricht
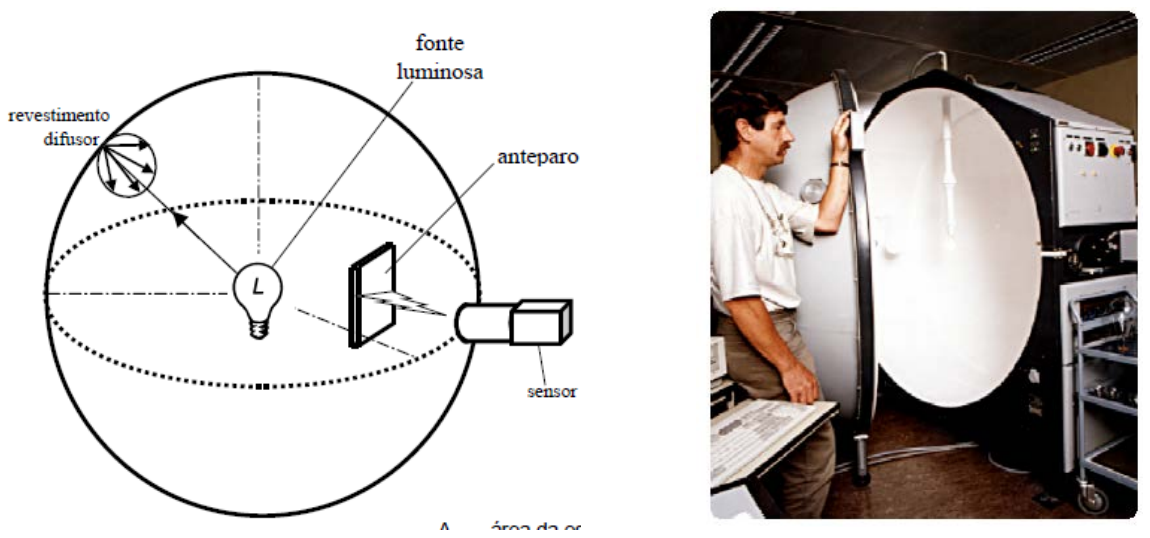

Fonte: KAISER, 2010.

Os diagramas fotométricos são a distribuição de luz realizada por uma fonte e pode ser representada por uma superfície definida pela distribuição 
espacial dos valores da intensidade luminosa em cada direção. É a chamada superfície fotométrica, visualizada na Figura 52.

Figura 52- Superfície fotométrica

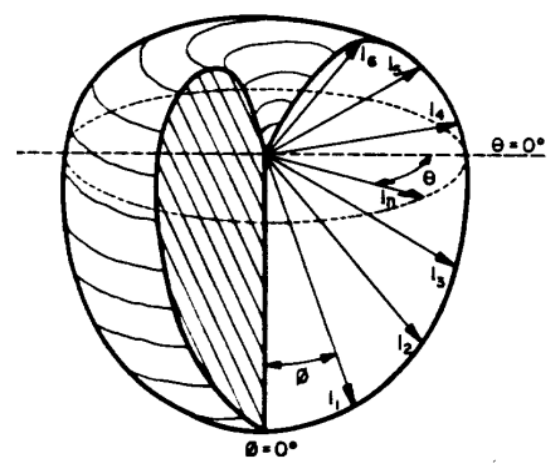

Fonte: MOREIRA, 2006.

Quando a fonte realiza uma distribuição espacial uniforme, a superfície fotométrica é uma esfera e, sendo espacial, não pode ser representada diretamente sobre um plano, isto é, em um diagrama de duas dimensões. Para que a representação seja possível, adotam-se projeções dessa superfície sobre um plano. A intersecção de uma superfície fotométrica por um plano que passa pelo centro da fonte luminosa é uma curva fotométrica horizontal, exemplificada na Figura 53, ou traçar outra curva fotométrica vertical, conforme Figura 54.

Figura 53 - Curva fotométrica horizontal

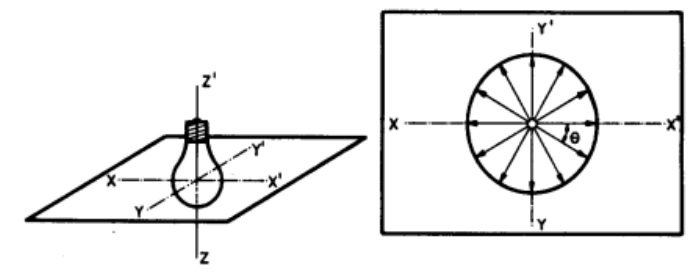

Fonte: MOREIRA, 2006 
Figura 54 - Curva fotométrica vertical

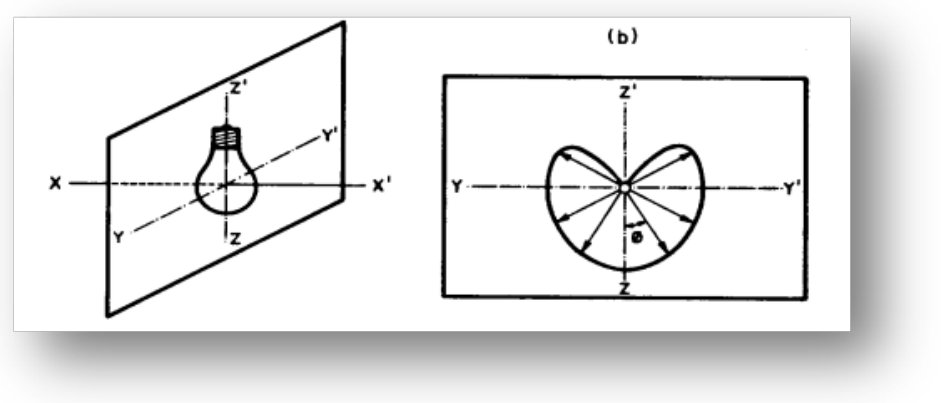

Fonte: MOREIRA, 2006.

\subsection{Iluminância}

Símbolo: E

Unidade: lux (Ix)

O melhor conceito sobre iluminância talvez seja: "densidade de luz necessária para uma determinada tarefa visual"(COSTA, 1998). Baseados em pesquisas realizadas com diferentes níveis de iluminação, os valores relativos à iluminância foram tabelados. No Brasil, esta tabela encontra-se na NBR 5413 - Iluminância de interiores e que na sua revisão passa a ser a Norma NBR ISO 8995-1: Iluminação de ambientes de trabalho (aprovada em fase de publicação).

A norma NBR 5413 será substituída em breve pela NBR ISO 8995-1Iluminação de ambientes internos de trabalho, estando em fase de consulta pública pela ABNT, conforme solicitação da Comissão CE-03:034.04 de Estudo para Aplicações Luminotécnicas e Medições Fotométricas da ABNT/CB-03 - Comitê Brasileiro de Eletricidade.

Por definição, iluminância é o limite da razão do fluxo luminoso d $\Phi$, incidente num elemento de superfície que contém o ponto dado, para uma área dA deste elemento, quando esta área tende para zero. Ou seja, é o fluxo luminoso incidente numa superfície por unidade de área. 


$$
E=\lim _{\Delta A \rightarrow 0} \frac{\Delta \Phi}{\Delta A}=\frac{d \Phi}{d A}
$$

\section{Fórmula 3}

Onde:

$\mathrm{d} \Phi=$ fluxo luminoso $(\mathrm{Im})$

$\mathrm{d} A=$ área $\left(m^{2}\right)$

$E$ = iluminância (lux)

Um lux corresponde à iluminância de uma superfície plana de um metro quadrado de área, sobre a qual incide perpendicularmente um fluxo luminoso de um lúmen. Importante notar que a iluminância está ligada a um ponto na superfície que independe da posição do observador, conforme figura 55.

Figura 55 - Iluminância está relacionada com a densidade de fluxo.

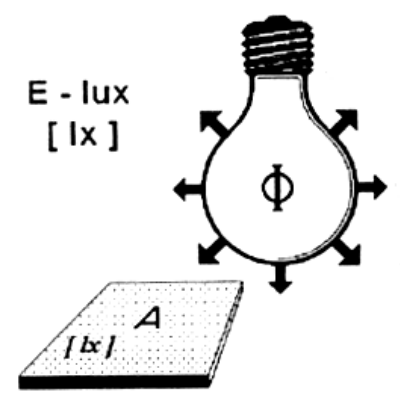

Fonte: COSTA, 2006

Normalmente nos trabalhos de iluminação emprega-se a iluminância média, que é dada pela expressão:

$$
E=\Phi \quad \text { Fórmula } 4
$$

A

Onde:

E = iluminância média (lux)

$\Phi=$ fluxo luminoso $(\mathrm{Im})$

$A=$ área $\left(m^{2}\right)$ 


\subsection{Luminância}

Símbolo: L ou NIT

Unidade: candela por metro quadrado (cd/m2) ou nit (nt)

É através da luminância que o homem enxerga, já que os raios luminosos não são visíveis e a sensação de luminosidade é decorrente da reflexão destes raios em uma superfície. A luminosidade visível é chamada luminância.

Logo:

_ lluminância é a luz incidente, não visível;

_ luminância é a luz refletida, visível.

A equação matemática que permite a determinação da luminância é:

$\mathbf{L}=\mathbf{I}$

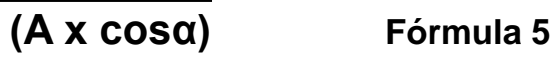

Fonte: IEC, 2007

Onde:

$L$ = luminância em cd/m²; (ou em nit)

I = intensidade luminosa em cd;

$\mathrm{A}=$ área projetada em $\mathrm{m}^{2} \mathrm{e}$

$\alpha=$ ângulo considerado em graus.

Em caso de desconhecimento do valor da intensidade luminosa, usase a equação matemática abaixo, que só é válida para o caso de difusores perfeitos, ou seja, paredes totalmente brancas, áreas cobertas de neve, entre outros exemplos caracterizados por uma superfície que reflita a luz igualmente a partir de qualquer ponto nela contido. 


\section{$L=(\rho \times E) \quad$ Fórmula 6 \\ $\pi$}

Onde:

$\rho=$ coeficiente de reflexão (número puro);

E = iluminância sobre essa superfície (em lux);

O coeficiente de reflexão ( $\rho$ ) é o quociente do fluxo incidente pelo fluxo refletido pela superfície:

$\frac{\rho=\rho \mathbf{i}}{\rho \mathbf{r}} \quad$ Fórmula 7

Este coeficiente varia de acordo com a cor e a textura das superfícies. A luminância está diretamente relacionada com os contrastes. Por exemplo, a leitura de páginas escritas em letras pretas (refletância 10\%) sobre o papel de fundo branco (refletância 85\%) revela que a luminância das letras é menor que a luminância do fundo, tornando a leitura menos cansativa. (COSTA, 2006 et.al. JALGBAUER, 2007).

\subsection{Curva de distribuição de intensidade luminosa (CDL)}

A distribuição das intensidades luminosas de uma luminária revela as características de distribuição da luz e é representada pelas curvas de distribuição de intensidade luminosa ou curva de distribuição luminosa ( $C D L$ ).

Estas, segundo a ABNT (1991), são geralmente representadas em coordenadas polares e mostram a variação da intensidade luminosa num plano que passa através da fonte (lâmpada ou luminária), em função do ângulo medido a partir de uma direção determinada. 
Para o levantamento fotométrico de luminárias internas é convencionado que as intensidades luminosas são obtidas variando-se os ângulos nas direções verticais e horizontais, em função da origem nadir, referência perpendicular ao plano formado pela luminária, passando pelo centro da mesma, no sentido inferior Os ângulos verticais $(\theta)$ podem variar de $0^{\circ} \leq \theta \leq 180^{\circ}$, e os ângulos horizontais $(\psi)$ de $0^{\circ} \leq \psi \leq 360^{\circ}$, conforme IESNA, 2000.

Em função da quantidade e características dos planos horizontais $(\psi)$ que representam a distribuição luminosa das luminárias, estas podem ser classificadas como:

- Simétricas axiais: São representadas apenas para ângulo horizontal $\Psi$ $=0^{\circ}$.

- Simétricas quadrilaterais: São representadas para ângulos horizontais $0^{\circ} \leq \psi \leq 90^{\circ}$

- Simétricas bilaterais: São representadas para ângulos horizontais $0^{\circ} \leq$ $\psi \leq 180^{\circ}$

- Assimétricas: São representadas para ângulos horizontais $0^{\circ} \leq \psi \leq$ $360^{\circ}$

\subsubsection{Classificação das luminárias de acordo com o direcionamento do fluxo luminoso}

Ainda em relação à distribuição do fluxo luminoso, as luminárias para iluminação interior são classificadas pela CIE (Commission Internationale de L'Éclairage) em grupos, conforme a parcela dos fluxos luminosos emitidos para o hemisfério superior e inferior da luminária. A Tabela 20 contém as informações da distribuição do fluxo luminoso em relação ao plano horizontal. 
Tabela 21 - Classificação da CIE de luminárias para iluminação geral, de acordo com fluxo luminoso (percentagem do fluxo luminoso total, por cima e por baixo do horizontal).

\begin{tabular}{|l|c|c|c|c|}
\hline \multirow{2}{*}{ Classe de luminária } & \multicolumn{3}{|c|}{ Fluxo luminoso em relação ao horizontal } \\
\cline { 2 - 5 } & \multicolumn{2}{|c|}{ Para cima } & \multicolumn{2}{c|}{ Para baixo } \\
\hline Direta & 0 & 10 & 90 & 100 \\
\hline Semi-direta & 10 & 40 & 60 & 90 \\
\hline Geral-difusa & 40 & 60 & 40 & 60 \\
\hline Direta-indireta & 40 & 60 & 40 & 60 \\
\hline Semi-indireta & 60 & 90 & 10 & 40 \\
\hline Indireta & 90 & 100 & 0 & 10 \\
\hline
\end{tabular}

Fonte: CIE, 1999.

- Iluminação direta: distribui 90 a 100\% do fluxo para o hemisfério inferior. A distribuição pode variar de fachos largos a concentrados, dependendo do material e geometria óptica da luminária.

- $\quad$ Iluminação semidireta: distribui 60 a 90\% do fluxo para o hemisfério inferior. As características são essencialmente parecidas com as da iluminação direta, com exceção de que o componente do fluxo luminoso superior ajuda a suavizar sombras e a melhorar as relações de brilho do ambiente, tornando o teto mais iluminado.

- $\quad$ Iluminação difusa geral: distribui 40 a $60 \%$ do fluxo para o hemisfério inferior. Este tipo de luminária distribui a luz aproximadamente igual em todas as direções. A iluminação direta / indireta ou mista corresponde a uma categoria especial dentro da iluminação difusa geral, correspondendo às luminárias que emitem pouca luz nos ângulos próximos à horizontal. Estas luminárias, geralmente, são mais adequadas, pois apresentam menores luminâncias na zona de ofuscamento direto $\left(45^{\circ}\right.$ a $\left.85^{\circ}\right)$.

- Iluminação semi-indireta: distribui 60 a 90\% do fluxo para o hemisfério superior. Possui características semelhantes a da iluminação indireta, exceto pelo fato de que a parcela de luz direta pode produzir certa direcionalidade para a tarefa visual, sem uma luminância excessiva do teto, e pode ser usada para adicionar brilho para a luminária. 
- $\quad$ Iluminação indireta: distribui 90 a $100 \%$ do fluxo para o hemisfério superior. Em instalações bem projetadas, o teto torna-se a fonte primária de luz, eliminando-se as sombras, uma vez que a luz passa a ser indireta.

Desta forma, em relação ao eixo vertical, as luminárias com fluxo direto são representadas por $0^{\circ} \leq \theta \leq 90^{\circ}$, as luminárias com fluxo indireto são representadas por $90^{\circ} \leq \theta \leq 180^{\circ}$, e as luminárias com fluxo direto e indireto são representadas por $0^{\circ} \leq \theta \leq 180^{\circ}$.

A iluminação direta é o tipo de iluminação mais utilizada em aplicações comerciais e é a mais eficiente energeticamente, por concentrar maior quantidade de luz no plano de trabalho. Na prática, os ambientes com iluminação direta possuem tetos mais escuros e, muitas vezes, propiciam sensações de ambientes menos iluminados para os ocupantes. Sombras nas áreas superiores das paredes também induzem a este tipo de sensação.

A Figura 56 representa curvas de distribuição de intensidade luminosas nos planos longitudinal, transversal e diagonal de uma luminária.

As curvas de distribuição luminosa (CDLs) podem ser apresentadas em candelas (cd) ou candelas por 1000 lumens (cd/1000lm). Entretanto, a segunda representação é a mais usual, pois independe do fluxo luminoso da lâmpada utilizada (IWASHITA, 2006).

Figura 56 - Curva de distribuição de intensidade luminosa conforme planos

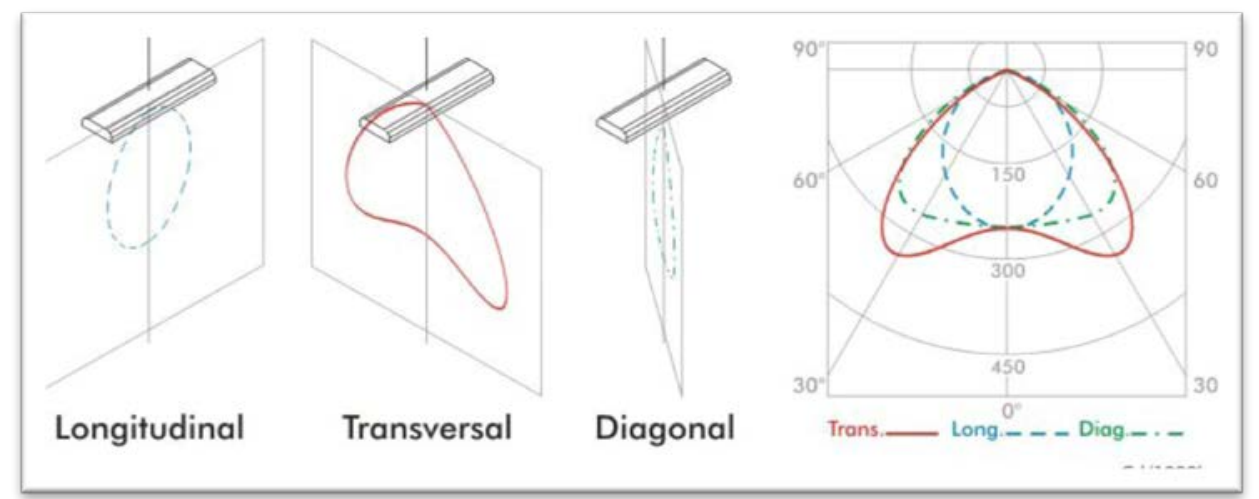

Fonte: IWASHITA, 2006. Catálogo Itaim, 2006. 
Figura 57 - Curva Polar de uma luminária fluorescente para lâmpada fluorescente tubular T8, modelo DBL 591 2x32W, INDELPA.

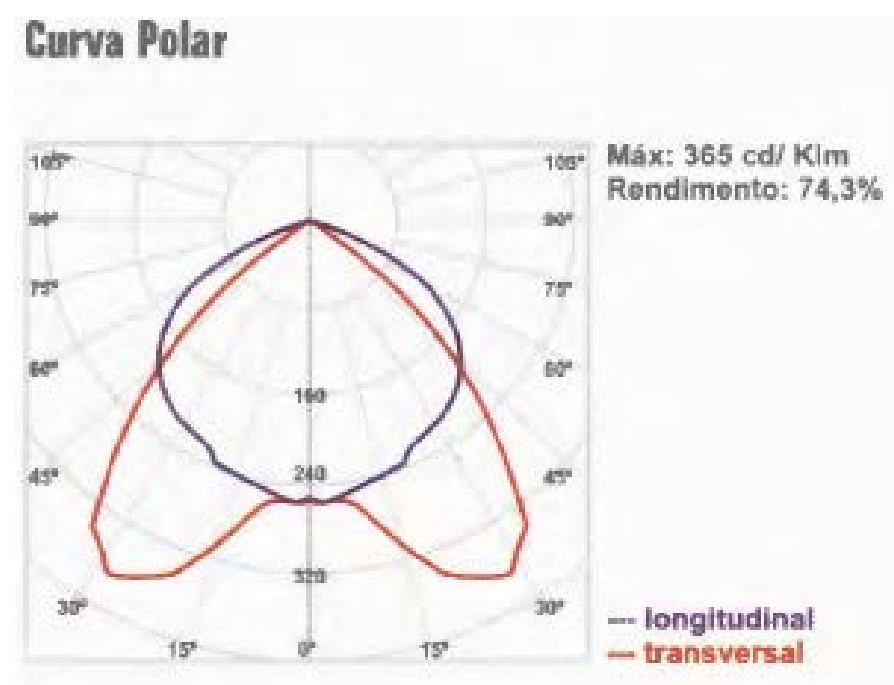

Fonte: INDELPA, 2012.

\subsection{Rendimento da luminária}

O rendimento da luminária (ou eficiência de uma luminária) é definido como a razão do fluxo luminoso emitido pela luminária e o fluxo luminoso total da(s) lâmpada(s).

Uma questão muito importante a ser observada quanto ao rendimento é que ele não considera a distribuição luminosa da luminária, englobando tanto o fluxo emitido para o hemisfério inferior como para o superior. Para a escolha de uma luminária eficiente deve-se, portanto, considerar luminárias com maiores rendimentos no hemisfério inferior, visto que a luz emitida para o hemisfério superior participa da iluminância somente indiretamente, via reflexão do teto. (LIBBE SMIT, 1991).

Nota-se que as luminárias com maiores rendimentos são luminárias sem componentes de controle de luz. Elementos como refletores, refratores, difusores e louvres diminuem o rendimento da luminária, na medida em que absorvem, refletem e transmitem a luz pelos materiais utilizados na sua confecção. 
Desta forma, na especificação de uma luminária, o rendimento ou eficiência deve ser ponderado, analisando-se conjuntamente a distribuição luminosa e o grau de controle de ofuscamento que a luminária deve possuir para a atividade a ser desenvolvida.

Recomenda-se, portanto, que o rendimento seja considerado para comparar luminárias do mesmo tipo e para mesma aplicação.

O rendimento de uma luminária varia de acordo com:

- Forma e curva óptica da luminária;

- Presença de componentes de controle de luz, como refletores, difusores, refratores e louvres;

- Características dos materiais da luminária; e

- Tipo de lâmpada utilizada e suas dimensões.

Os componentes de controles de luz são os que mais influenciam o rendimento da luminária. A refletância do refletor muda significantemente em função do material com que é feito e pode variar de 60\%, com refletores com pintura branca, a 95\% com refletores especulares. Os refletores geralmente produzem poucos benefícios, a menos que sejam incorporados à geometria da luminária e sejam elaborados de forma a fornecer uma refletância e distribuição ótima da luz.

A eficiência da luminária é normalmente decorrente da sua configuração física e da seleção de materiais utilizados (IESNA, 2000).

Fabricantes de alumínio mostram que para uma mesma luminária, são possíveis variações significativas de rendimento, incrementando a reflexão em $10 \%$ a $15 \%$, apenas em função da variação do tipo de alumínio utilizado e tratamento de superfície dado a ele. 
Figura 58 - Comparativo de uma luminária com ou sem conjunto ótico.

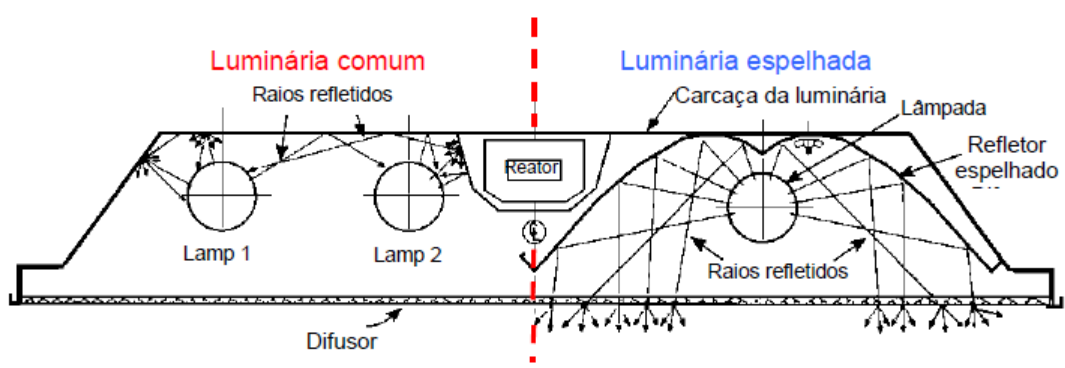

Fonte: KAISER, 2010.

\subsection{Fator de utilização (FU)}

É usado para o cálculo da iluminação geral média e pode ser obtido através de duas metodologias: Método dos Lúmens (adotado pela CIE) e Método das Cavidades Zonais (adotado pela IESNA). Os métodos diferem entre si, sendo que o primeiro é dado em função do índice do recinto (Kd ou Ki) e o segundo em função do índice da cavidade da sala RCR (Room Cavity Ratio).

O fator de utilização descreve a efetividade com que uma luminária distribui a luz sobre um plano de trabalho horizontal. É definido como a razão entre o fluxo luminoso recebido numa superfície de referência e a somatória do fluxo luminoso emitido pelas lâmpadas da instalação (ABNT, 1991). Indicam, desta forma, a eficiência luminosa do conjunto lâmpada e luminária naquele recinto.

Estes valores são geralmente fornecidos em catálogos de fabricantes, por tabelas, em função das refletâncias do teto, paredes, piso e da configuração do ambiente (RCR ou K), e são tipicamente entre 0 e 1.

Ressalte-se que luminárias que não são projetadas para produzir iluminação geral, como luminárias assimétricas ou luminárias para destaque, não apresentam fator de utilização. 
Figura 59 - Fator de utilização pelo método dos lúmens CIE, de uma luminária fluorescente para lâmpada fluorescente tubular T8 modelo DBL 591 2×32W, INDELPA.

Fator de Utilizaçăo K [Método dos Lumens]

\begin{tabular}{|l|l|l|l|l|l|l|l|l|l|}
\hline $\mathbf{K}$ & $\mathbf{7 5 1}$ & $\mathbf{7 3 1}$ & $\mathbf{7 1 1}$ & $\mathbf{5 5 1}$ & $\mathbf{5 3 1}$ & $\mathbf{5 1 1}$ & $\mathbf{3 5 1}$ & $\mathbf{3 3 1}$ & $\mathbf{3 1 1}$ \\
$\mathbf{0 . 6 0}$ & 0.39 & 0.35 & 0.31 & 0.39 & 0.34 & 0.31 & 0.39 & 0.34 & 0.31 \\
$\mathbf{0 . 8 0}$ & $0 . \mathbf{4 7}$ & 0.42 & 0.39 & 0.46 & 0.42 & 0.39 & 0.45 & 0.42 & 0.39 \\
\hline $\mathbf{1 . 0 0}$ & 0.54 & 0.50 & 0.47 & 0.53 & 0.49 & 0.46 & 0.52 & 0.48 & 0.46 \\
$\mathbf{1 . 2 5}$ & 0.60 & 0.57 & 0.54 & 0.59 & 0.56 & 0.54 & 0.59 & 0.56 & 0.54 \\
\hline $\mathbf{1 . 5 0}$ & 0.61 & 0.57 & 0.54 & 0.60 & 0.56 & 0.54 & 0.59 & 0.56 & 0.54 \\
\hline $\mathbf{2 . 0 0}$ & 0.68 & 0.65 & 0.62 & 0.66 & 0.64 & 0.62 & $\mathbf{0 . 6 5}$ & 0.62 & 0.61 \\
\hline $\mathbf{2 . 5 0}$ & 0.68 & 0.65 & 0.62 & 0.67 & 0.64 & 0.62 & $\mathbf{0 . 6 5}$ & 0.63 & 0.61 \\
\hline $\mathbf{3 . 0 0}$ & 0.74 & 0.71 & 0.70 & 0.72 & 0.71 & 0.69 & 0.70 & 0.70 & 0.68 \\
\hline $\mathbf{4 . 0 0}$ & 0.74 & 0.72 & 0.71 & 0.72 & 0.71 & 0.70 & 0.71 & 0.70 & 0.68 \\
\hline $\mathbf{5 . 0 0}$ & 0.74 & 0.72 & 0.71 & 0.73 & 0.71 & 0.70 & 0.71 & 0.70 & 0.69 \\
\hline
\end{tabular}

Fonte: INDELPA, 2012.

Figura 60- Fator de utilização pelo método das cavidades zonais de uma luminária fluorescente para lâmpada fluorescente tubular T8 modelo DBL 591 2×32W, INDELPA.

Fator de Utilizaçăo [RCR] Método das Cavidades Zonais

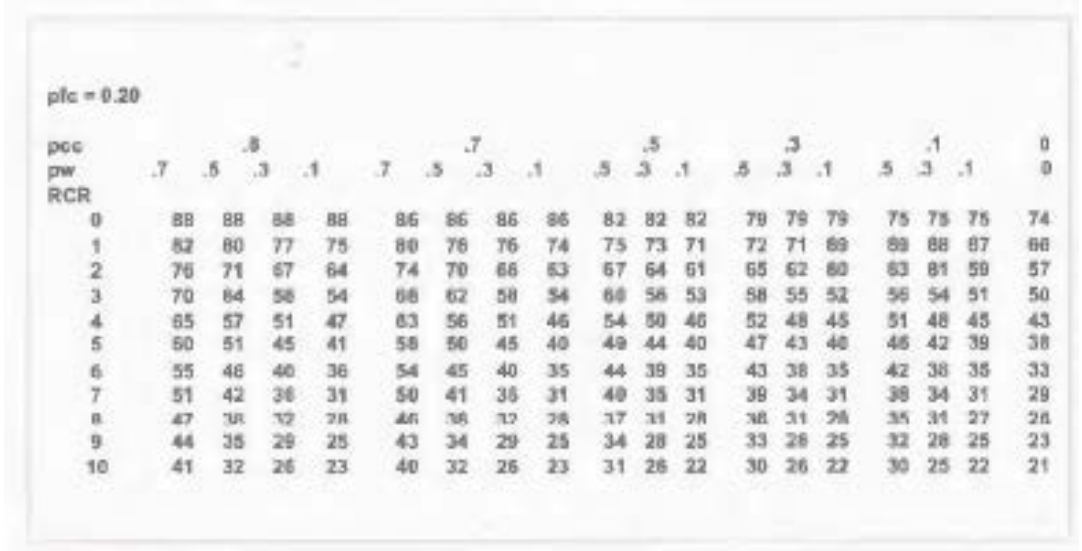

Fonte: INDELPA, 2012. 


\subsection{Fluxo zonal da luminária}

O fluxo zonal de uma luminária representa o fluxo luminoso emitido em zonas de ângulos sólidos cônicos. O método zonal é utilizado para determinação do fluxo luminoso total da luminária, emitido para o hemisfério inferior ou superior ou em zonas específicas.

Em luminárias comerciais e industriais, as zonas fotométricas são seções da esfera imaginária que contém a luminária, sendo que as extremidades da seção são ângulos concêntricos ao eixo de simetria da luminária. Conforme a precisão desejada e o tipo de curva fotométrica, podem ser consideradas zonas de $1^{\circ}, 2^{\circ}, 5^{\circ}$ e $10^{\circ}$ para o cálculo do fluxo luminoso (BRADLEY et al, 1971).

Em luminárias comerciais são considerados para o cálculo, geralmente, 18 zonas com ângulos sólidos de 10. Em cada zona é calculado o fluxo luminoso emitido pela luminária através de equações e, posteriormente, os fluxos zonais são somados para determinação do fluxo luminoso total da luminária.

\subsection{Diagrama de luminância}

O diagrama de luminância indica as luminâncias de uma luminária nos ângulos críticos de visualização (ângulos entre $45^{\circ}$ a $85^{\circ}$ a partir da vertical), sendo que, na atualização da Norma ABNT NBR ISO 8995-1/2012, este diagrama contrapõe as luminâncias críticas às retas que definem classes de qualidade conforme o nível de iluminância de serviço, conforme ilustra a figura 61.

As classes de qualidade são definidas pela CIE e indicam:

- Classe A: qualidade muito elevada

- $\quad$ Classe B: qualidade elevada

- $\quad$ Classe C: qualidade média

- $\quad$ Classe D: qualidade baixa

- $\quad$ Classe E: qualidade muito baixa 
Figura 61 - Ângulos críticos de visualização

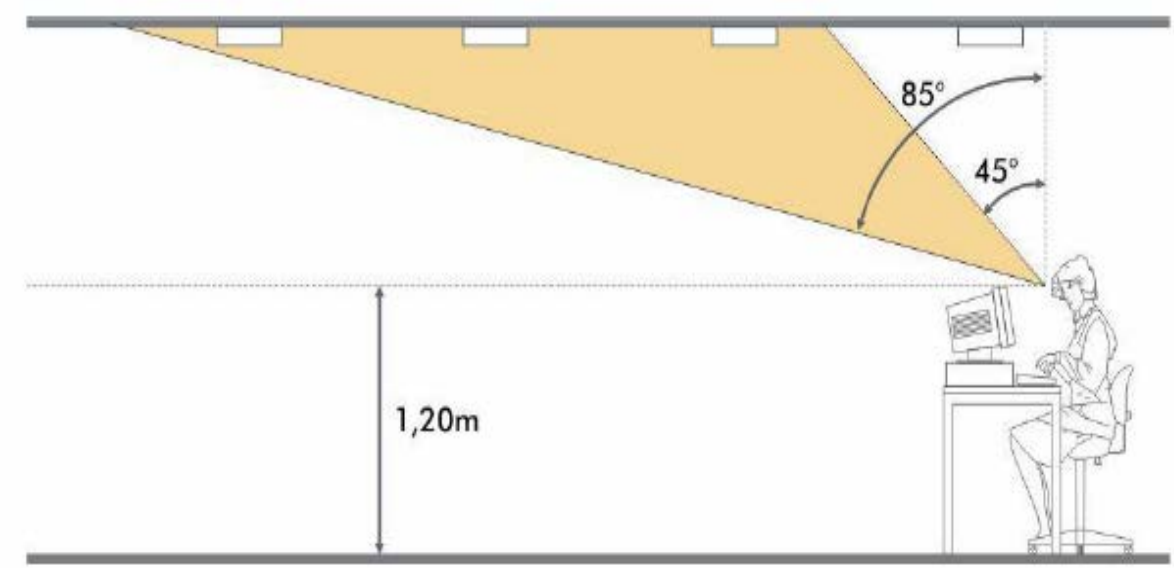

Fonte: ITAIM,2010.

Figura 62- Diagrama de luminâncias $L\left(\mathrm{~cd} / \mathrm{m}^{2}\right)$

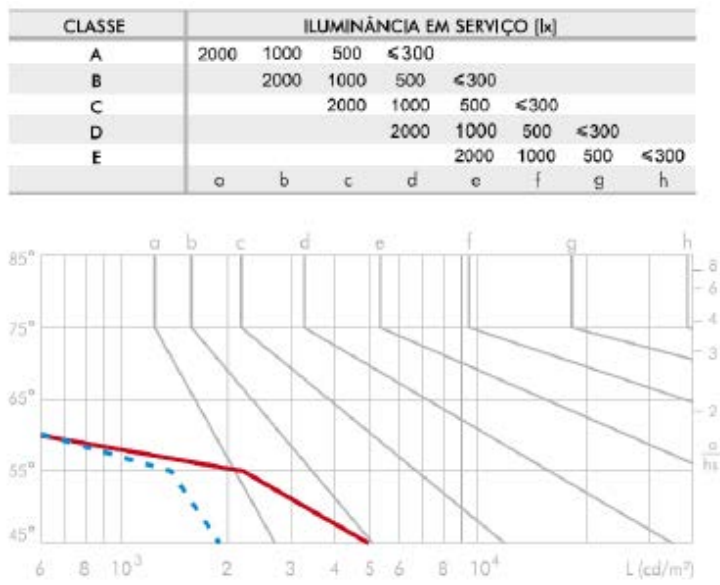

Fonte: ITAIM, 2010.

\subsection{0 Índice de ofuscamento unificado UGR (Unified Glare Rating)}

É a definição da CIE para o nível de desconforto por ofuscamento estabelece o valor máximo permitido deste nível unificado de projeto para uma instalação de iluminação (os detalhes método UGR estão estabelecidos na CIE 117-1995). 
O valor referente ao ofuscamento desconfortável de uma instalação de iluminação deve ser determinado pelo método tabular do Índice de Ofuscamento Unificado da CIE, O UGR, baseado na seguinte fórmula, conforme NBR 8995-1.

$$
U G R=8 . \log \frac{(0,25}{L b} \cdot \frac{\left.\sum L 2 . \omega\right)}{\rho 2} \quad \text { Fórmula } 8
$$

Onde:

- Lb é a luminância de fundo $\left(\mathrm{cd} / \mathrm{m}^{2}\right)$

- L é a luminância da parte luminosa de cada luminária na direção do olho do observador $\left(\mathrm{cd} / \mathrm{m}^{2}\right)$

- $\omega$ é o ângulo sólido da parte luminosa de cada luminária junto ao olho do observador (esterradiano)

- p é o índice de posição Guth de cada luminária individualmente, relacionado ao seu deslocamento a partir da linha de visão.

Os valores do UGR estão baseados na posição padrão do observador, que foi validada pelo método tabular UGR com razão de 1:1 da relação entre espaçamento e altura. Os dados do UGR devem ser corrigidos para fluxo luminoso inicial das lâmpadas utilizadas. Se a instalação da iluminação for composta por tipos diferentes de luminárias com distintas fotometrias e/ou lâmpadas, a determinação do valor UGR deve ser aplicada para cada combinação lâmpada/luminária da instalação. Desta maneira, o maior valor do UGR encontrado deverá ser considerado como um valor típico para a instalação inteira e deve estar em conformidade com o UGR limite. Todas as suposições feitas na determinação do UGR devem ser relatadas na documentação do projeto.

$O$ valor $U_{G} R_{L}$ da instalação não deve exceder o valor estabelecido na seção 5 da Norma ABNT NBR ISO 8995-1/2012- lluminação de ambientes internos de trabalho (norma aprovada em fase de publicação) e foram obtidos na escala UGR, na qual cada passo na escala representa uma mudança significativa no efeito do ofuscamento, e o menor valor 13 representa o ofuscamento desconfortável menos perceptível.

A escala UGR $\mathrm{L}_{\mathrm{L}}$ : $13-16-19-22-25-28$. 
Figura 63 - Diagrama definindo os índices de ofuscamento UGR

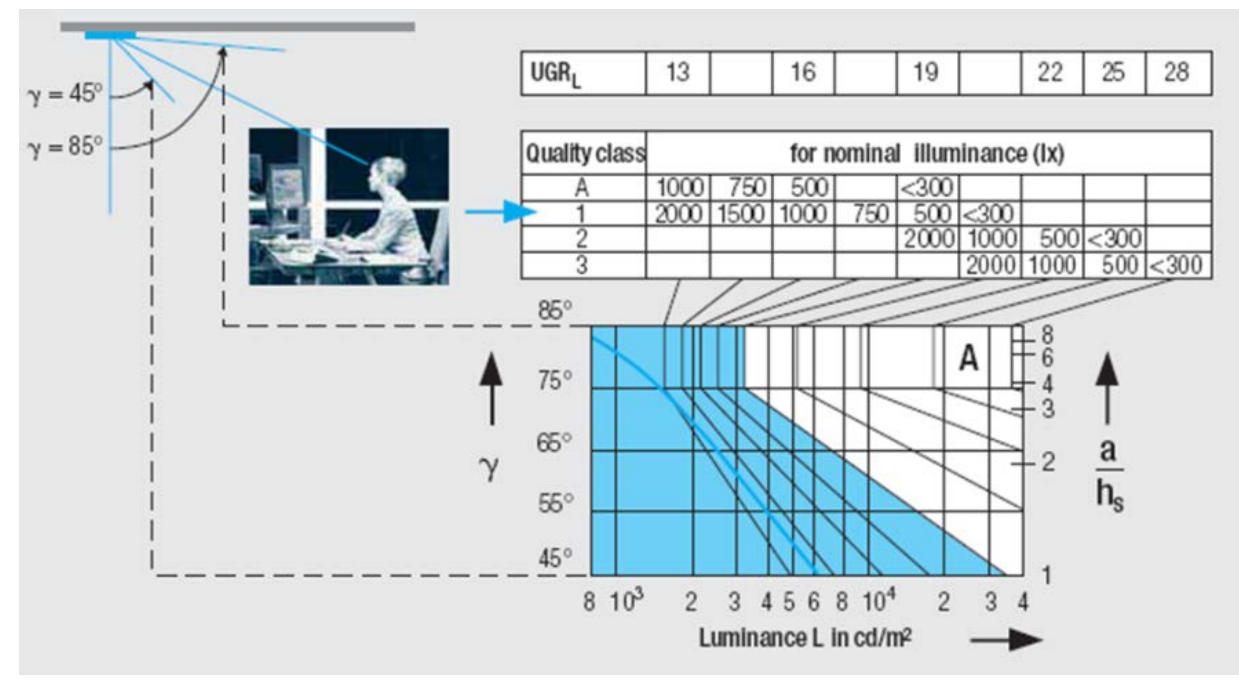

Fonte: WILSON TEIXEIRA, 2012.

Tabela 22 - Exemplos de luminâncias que definem os índices de ofuscamento UGR $\mathrm{L}_{\mathrm{L}}$

\begin{tabular}{|c|l|}
\hline $\begin{array}{c}\text { Índice limite de } \\
\text { ofuscamento unificado } \\
\left(\mathbf{U G R}_{\mathrm{L}}\right)\end{array}$ & \multicolumn{1}{c|}{ Tipo de ambiente, tarefa ou atividade. } \\
\hline $\mathbf{5 1 6}$ & Desenhos técnicos, torre de controle do tráfego aéreo. \\
\hline $\mathbf{5 1 9}$ & $\begin{array}{l}\text { Escritórios, estações de CAD, inspeção de cor } \\
\text { (laboratórios). }\end{array}$ \\
\hline $\mathbf{2 2 2}$ & $\begin{array}{l}\text { Indústrias artesanais, salas comuns de estudantes e salas } \\
\text { de reunião. }\end{array}$ \\
\hline $\mathbf{2 2 5}$ & Indústrias pesadas, pistas de tráfego. \\
\hline $\mathbf{2 2 8}$ & Plataformas ferroviárias, estacionamentos. \\
\hline
\end{tabular}

Fonte: Norma ABNT NBR ISO 8995-1: lluminação de ambientes de trabalho (Norma aprovada em fase de publicação)

\subsection{Fator de manutenção}

Com o aumento do tempo do serviço, o fluxo luminoso entregue por um sistema de iluminação diminui com o envelhecimento das lâmpadas, das luminárias e o acúmulo de pó. A queda antecipada do fluxo luminoso depende da escolha das lâmpadas, luminárias e dispositivos de operação, 
bem como das condições de operação e do ambiente nos quais elas estão expostas.

A fim de garantir que um nível específico de iluminação - expresso pela iluminância mantida $\left(\bar{E}_{\mathrm{m}}\right)^{29}$ - seja alcançado por um período de tempo razoável, um fator de manutenção considerado adequado deve ser aplicado pelo projetista da iluminação, a fim de que seja considerada a diminuição no sistema de fluxo luminoso.

O fator de manutenção é a relação entre a iluminância mantida e o nível de iluminância quando o sistema de iluminação é novo.

Figura 64 - Iluminância durante o período de uso de um sistema de iluminação

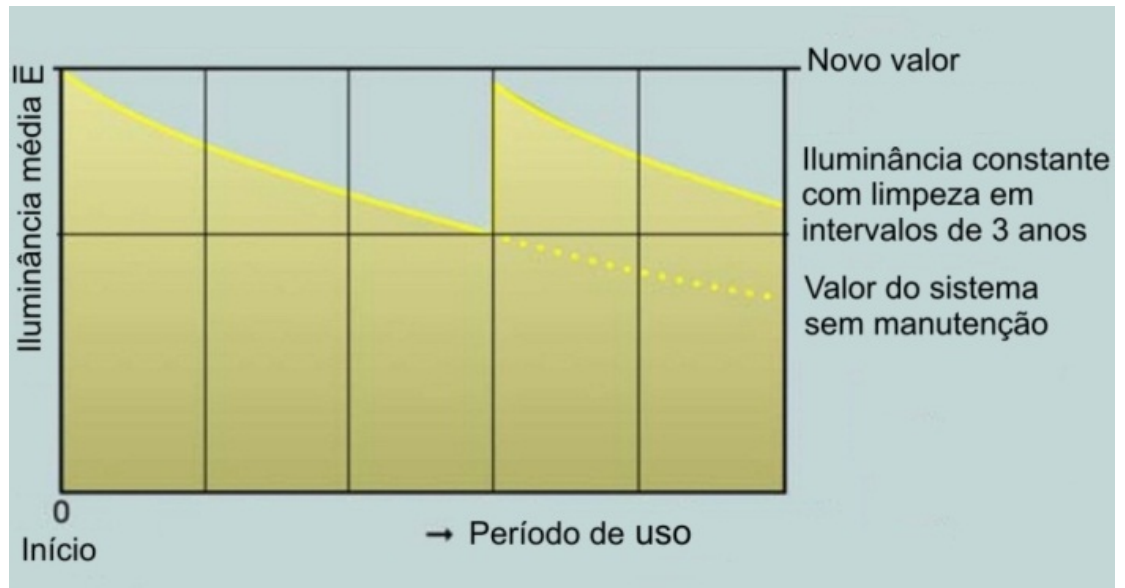

Fonte: CIE 97:2005 -Maintenance of Indoor Electric Lighting Systems.

Os valores do fator de manutenção individual podem ser obtidos com os fabricantes ou ser encontrados em curvas do valor médio padrão e em publicações de iluminação, como o Guia de Manutenção de Sistemas Elétricos, CIE 097:2005 - Maintenance of Indoor Electric Lighting Systems . Este guia indica que durante a vida de uma instalação de iluminação a luz disponível para a tarefa progressivamente diminui, isto devido à acumulação de sujeiras na superfície e ao envelhecimento dos equipamentos. A taxa de redução é influenciada pela escolha do equipamento e as condições ambientais e de funcionamento.

\footnotetext{
${ }^{29}$ Iluminância mantida - Valor abaixo do qual a iluminância média da superfície especificada não poderá ser reduzida.
} 
O projetista, no momento da escolha dos sistemas, deve considerar a queda do fluxo luminoso do conjunto, utilizando-se de um fator de manutenção e de um planejamento, por meio de programas de manutenção adequados para limitar a depreciação.

A futura Norma ABNT NBR ISO 8995-1 - lluminação de ambientes de trabalho (em fase de publicação), não indica o uso de um fator mínimo de manutenção inferior a 0,70.

A Norma ABNT NBR ISO 8995-1,também recomenda a consulta à CIE 97, por considerar que o sistema de iluminação deve ser projetado com fator de manutenção geral calculada para o equipamento de iluminação selecionado, conforme o ambiente espacial e programação de manutenção especificada. Um fator de alta manutenção, juntamente com um programa de manutenção eficaz, promove o design de eficiência energética dos sistemas de iluminação e limita os requisitos de energia instalados de iluminação.

O guia da CIE 97 também descreve os parâmetros que influenciam o processo de depreciação e desenvolve o procedimento para estimar o fator de manutenção de sistemas elétricos de iluminação interior. A publicação fornece informações sobre a seleção do equipamento e da estimativa dos ciclos de manutenção econômica e dá conselhos sobre técnicas de manutenção. Mostra, ainda, alguns exemplos de dados, mas para uma maior precisão recomenda que os dados devem ser obtidos a partir dos fabricantes

Exemplos de fatores de manutenção e os seus homólogos inversos, fatores de novo valor, são citados a seguir, com base em dados disponíveis no momento.

As lâmpadas são substituídas individualmente, assim que falham, ou em grupo, quando a iluminância cai para o nível da iluminância mantida.

A determinação do fator de manutenção (MF) é um múltiplo de fatores e determinado como exemplificado pela Fórmula 9 a seguir:

\section{MF = LLMF $\times$ LSF $\times$ LMF $\times$ RMF Fórmula 9}

Onde:

LLMF - leva em conta o declínio da potencia em lúmen

LSF - leva em conta o efeito do envelhecimento da lâmpada, 
LMF - leva em conta os efeitos de redução de potencia de luz, devido ao acúmulo de sujeira nas luminárias.

RMF - leva em conta a redução da refletância devido à deposição de sujeira nas superfícies da sala. Em muitos casos, pode-se supor que "fator de manutenção da falha da lâmpada = 1", porque a falha individual das lâmpadas conduz a uma queda inaceitável do nível iluminação. Por esta razão, torna-se necessária a substituição individual da lâmpada.

Tabela 23 - Exemplos de fatores de manutenção para sistemas de iluminação de interiores com lâmpadas fluorescentes.

\begin{tabular}{|c|c|c|}
\hline $\begin{array}{c}\text { Fator de } \\
\text { manutenção }\end{array}$ & $\begin{array}{c}\text { Fator para } \\
\text { o novo } \\
\text { valor }\end{array}$ & Exemplo \\
\hline 0,80 & 1,25 & $\begin{array}{l}\text { Ambiente muito limpo, ciclo de manutenção de } 1 \text { ano, } \\
2.000 \text { h/ano de vida até a queima, com substituição da } \\
\text { lâmpada a cada } 8.000 \text { h, substituição individual, luminárias } \\
\text { direta e direta/indireta, com uma pequena tendência de } \\
\text { coleta de poeira, LLMF = 0,93; LSF = } 1,00 ; \text { LWF =0,90; } \\
\text { RMF = } 0,96\end{array}$ \\
\hline 0,67 & 1,50 & $\begin{array}{l}\text { Carga de poluição normal no ambiente, ciclo de } \\
\text { manutenção de } 3 \text { anos, } 2.000 \text { h/ano de vida até a queima, } \\
\text { com substituição da lâmpada a cada } 12.000 \mathrm{~h} \text {, substituição } \\
\text { individual, luminárias direta e direta/indireta, com uma } \\
\text { pequena tendência de coleta de poeira, LLMF = 0,91; LSF } \\
=1,00 ; \mathrm{LWF}=0,80 ; \mathrm{RMF}=0,90\end{array}$ \\
\hline 0,57 & 1,75 & $\begin{array}{l}\text { Carga de poluição normal no ambiente, ciclo de } \\
\text { manutenção de } 3 \text { anos, } 2.000 \text { h/ano de vida até a queima, } \\
\text { com substituição da lâmpada a cada } 12.000 \mathrm{~h} \text {, substituição } \\
\text { individual, luminárias com uma tendência normal de coleta } \\
\text { de poeira, LLMF = 0,91; LSF = 1,00; LWF = 0,74; RMF = } \\
0.83\end{array}$ \\
\hline 0,50 & 2,00 & $\begin{array}{l}\text { Ambiente sujo, ciclo de manutenção de } 3 \text { anos, } 8.000 \\
\text { h/ano de vida até a queima, com substituição da lâmpada } \\
\text { a cada } 8.000 \text { h, LLB, substituição em grupo, luminárias } \\
\text { com uma tendência normal de coleta de poeira, LLMF = } \\
0,93 ; \text { LSF = 0,93; LWF = 0,65; RMF = 0,94. }\end{array}$ \\
\hline
\end{tabular}

Fonte: CIE 97:2005 -Maintenance of Indoor Electric Lighting Systems 


\subsubsection{Fatores de manutenção de referência}

A multiplicação descrita acima, que objetiva determinar o fator de manutenção a partir de componentes individuais, oferece muitas oportunidades ao projetista da iluminação, com o propósito de que sejam otimizados os intervalos de manutenção no sistema de manutenção - e por este motivo o investimento no sistema de iluminação e os custos operacionais -, através da utilização de lâmpadas adequadas, de luminárias e dos dispositivos de operação.

Tabela 24 - Fatores de manutenção para sistemas de iluminação de interiores com lâmpadas fluorescentes, conforme condições da instalação.

\begin{tabular}{|l|c|}
\hline Onde uma ou mais das seguintes condições se aplicam, os fatores de & \\
manutenção podem geralmente ser incrementados. & \\
\hline - Utilização de lâmpadas sujeitas a pequena depreciação da luz & $\mathbf{0 , 8}$ \\
(dependendo da vida até a queima); por exemplo, lâmpadas & \\
fluorescentes & \\
- Utilização de luminárias como pequena tendência de coleta de \\
poeira
\end{tabular}

Fonte: CIE 97:2005 -Maintenance of Indoor Electric Lighting Systems. 
Para uma estimativa do planejamento do projeto ou onde informações detalhadas não estão disponíveis, inicialmente parece razoável que se assuma um fator de manutenção de referência de 0,67.

Mais tarde, quando as lâmpadas e as luminárias utilizadas forem identificadas e o ambiente e as condições de operação forem conhecidas, o valor de referência pode ser modificado.

O fator de manutenção é algumas vezes abreviado por MF. As abreviações foram tiradas da publicação CIE 97.

\subsubsection{Fator de manutenção do fluxo luminoso LLMF}

Como o tempo de serviço aumenta o fluxo luminoso emitido de praticamente qualquer lâmpada também diminui, devido ao resultado do envelhecimento. O quanto este decréscimo é de forma gradual e acentuada, dependerá do tipo e do valor em watt da lâmpada em questão e, onde aplicável, do dispositivo de operação utilizado. A relação do fluxo luminoso após um determinado número de horas de operação do fluxo luminoso, quando a lâmpada era nova, é indicada pelo fator de manutenção do fluxo luminoso (LLMF).

Os valores LLMF podem ser obtidos com os fabricantes, encontrados em curvas de valores médios padronizados e em publicações sobre iluminação como a publicação CIE 97- Maintenance of indoor electric lighting systems.

\subsubsection{Fator de sobrevivência da lâmpada LSF}

Cada lâmpada em um sistema de iluminação possui uma vida única, que é maior ou menor que a média da vida útil. $A$ vida média útil é o número de horas onde um grupo de lâmpadas sob observação funciona antes que a metade das lâmpadas falhe. A probabilidade que uma referida série ainda funcionará após um determinado número de horas de operação é expressa pelo fator de sobrevivência da lâmpada (LSF).

Tal como acontece com o fator de manutenção do fluxo luminoso, a magnitude e o tempo do fator de sobrevivência da lâmpada dependem do tipo e do valor em watt da lâmpada em questão. No caso das lâmpadas de 
descarga, o LSF também dependerá do dispositivo de operação utilizado e a frequência de operação do sistema.

No caso de lâmpadas fluorescentes, a vida média útil é normalmente calculada com base em um ciclo de acendimento de $23 / 4 \mathrm{~h}$ ligada por $1 / 4 \mathrm{~h}$ desligada. Com as lâmpadas de descarga, o ciclo de acendimento é de $11 \mathrm{~h}$ ligada por $1 \mathrm{~h}$ desligada. Os valores LSF são obtidos a partir das mesmas fontes dos valores LLMF.

\subsubsection{Fator de manutenção da luminária LMF}

De um modo geral, a sujeira depositada sobre as lâmpadas e as luminárias provoca uma redução maior no fluxo luminoso do que qualquer outro fator. O grau de perda de luminosidade depende do tamanho e natureza das partículas do ar poluente, do projeto das luminárias e das lâmpadas nelas utilizadas.

A publicação CIE 97 propõe um esquema de seis estágios do tipo de codificação em luminárias comuns. Aqui, dependendo do tipo da luminária e o acúmulo de poeira/sujeira, os fatores de manutenção da luminária (LMF) podem ser determinados como uma função do tempo em que as luminárias passaram pelo sistema de iluminação desde a última operação de limpeza.

\subsubsection{Fator de manutenção da sala RMF}

O fator de manutenção da sala (RMF) pode ser definido como a relação entre a utilância ${ }^{30} \mathrm{em}$ um dado momento com a utilância quando a ultima limpeza das superfícies da sala foi realizada.

Como a utiância, o fator de manutenção da sala depende basicamente do tamanho da sala, da refletância das superfícies da sala e da distribuição do fluxo luminoso do sistema de iluminação. Além disso, o fator de manutenção da sala depende do tipo e da quantidade de sujeira no ar, que têm uma relação direta na redução da refletância da superfície da sala.

\footnotetext{
${ }^{30}$ Utilância - De uma instalação de iluminação, e em relação a uma superfície de referência dada, é a razão do fluxo luminoso recebido pela superfície de referência, para a soma dos fluxos totais das luminárias individuais da instalação. Unidade: (U).
} 
6 DADOS SECUNDARROS : PROCESSOS INDUSTRIAAS EMMPREGAADOS NOS SISTERMAS DE ILUMUNANARO

\subsection{Introdução}

O alumínio é o elemento metálico não ferroso ${ }^{31}$ mais abundante na crosta terrestre (8\%), depois do oxigênio e do silício. Mesmo utilizado milênios antes de Cristo, o alumínio começou a ser produzido comercialmente há cerca de 150 anos. Sua produção atual supera a soma de todos os outros metais não ferrosos.

Figura 65 - Elementos metálicos não-ferrosos na crosta terrestre.

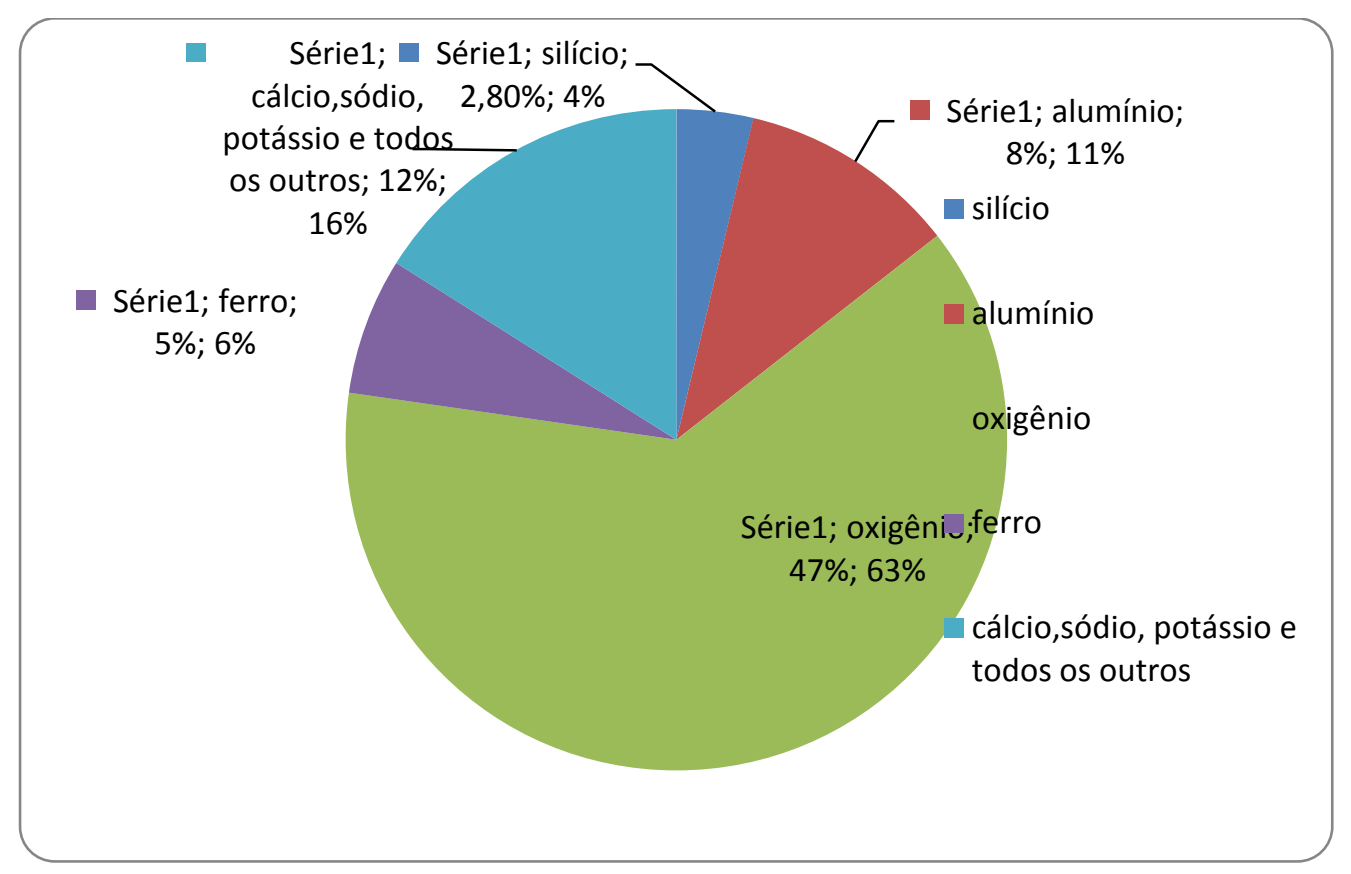

Fonte: European Aluminium Association, 2009.

Há mais de sete mil anos, os ceramistas da Pérsia fabricavam vasos de barro com óxido de alumínio ${ }^{32}$, conhecido atualmente como alumina ${ }^{33} \mathrm{e}$, 30 séculos mais tarde, os egípcios e babilônicos utilizavam outro composto similar em seus cosméticos e produtos medicinais. Até então, nada se sabia

\footnotetext{
${ }^{31}$ Não-ferroso - O termo é usado para indicar outros metais e ligas sem uma apreciável quantidade de ferro, como por exemplo ligas de cobre e de alumínio.

${ }^{32}$ Óxido de alumínio $\left(\mathrm{Al}_{2} \mathrm{O}_{3}\right)$ - Conhecido com alumina, é um composto químico de oxigênio e alumínio.

${ }^{33}$ Alumina - Óxido de alumínio de alta pureza que, por meio do processo de redução, dá origem ao alumínio metálico.
} 
sobre o metal na forma como o conhecemos hoje. O seu desconhecimento ao longo do tempo deve-se ao fato que, ao contrário de outros elementos metálicos como o cobre e o ferro, o metal puro não é encontrado naturalmente, existindo sempre combinações com outros elementos, principalmente o oxigênio, com o qual forma um óxido extremamente duro, conhecido como alumina.

O processo percorrido até conhecermos o alumínio na sua forma atual foi longo. Em 1809, o químico inglês Humphrey Davy foi o mentor da descoberta do que até então mais se aproximava do alumínio, fundindo ferro na presença de alumina. Davy propôs o nome de alumium para este metal, e, mais tarde, concordou em alterá-lo para aluminum. Pouco tempo depois, o nome aluminium (alumínio) foi adotado para concordar com a terminação do nome da maior parte dos elementos, generalizando-se esta designação por todo o mundo.

Em 1821 o francês Pierre Berthier descobre a bauxita, um minério avermelhado que contém $52 \%$ de óxido de alumínio, perto da aldeia de Lês Baux, no sul da França. Além da bauxita, o único minério que serve de matéria-prima para o metal é a nefelina ${ }^{34}$, um silicato de sódio, potássio e alumínio. Em 1825 o físico dinamarquês Hans Christian Oersted consegue isolar o alumínio de outra maneira, a partir do cloreto de alumínio na forma como é conhecido hoje.

A primeira obtenção do alumínio por via química foi realizada em 1854, pelo químico francês Henry Saint-Claire Deville. Em 1855, em uma exposição de Paris, Deville apresenta o primeiro lingote ${ }^{35}$ de um metal muito mais leve que o ferro.

Torna-se público, em 1886, o processo de obtenção de alumínio por meio da redução eletrolítica da alumina dissolvida em banho fundido de criolita $^{36}$. Esse procedimento foi desenvolvido separadamente pelo norteamericano Charles Martin Hall e pelo francês Paul Louis Toussaint Héroult, que o descobriram e o patentearam-no quase simultaneamente. Esse processo ficou conhecido como Hall-Heróult, e já neste período percebeu-se

\footnotetext{
${ }^{34}$ Nefelina - Mineral silicato de alumínio e sódio do grupo dos feldspatóides ( $\mathrm{NaAlSiO}_{4}$ ).

${ }^{35}$ Lingote - É o produto fundido na planta de redução, que se destina a fabricações de outros produtos por meio dos processos de laminação e extrusão.

${ }^{36}$ Criolita - Mineral fluoreto de sódio e alumínio $\left(\mathrm{Na}_{3} \mathrm{AlF}_{6}\right)$.
} 
a grande abrangência de aplicação que o metal teria em distintos setores da indústria.

Inicialmente, o custo de produção do alumínio era elevado e suas primeiras aplicações foram limitadas a trabalhos luxuosos, como em estatuetas e placas comemorativas. Com o desenvolvimento dos processos industriais, o metal passou a estar disponível em maiores quantidades, sendo gradualmente utilizado em utensílios de cozinha e em alguns dos primeiros automóveis que já possuíam painéis revestidos de alumínio comercialmente puro.

No início do Século $X X$, com o rápido e notável crescimento da importância do alumínio, as indústrias que o processavam começaram a trabalhar na produção de ligas de alumínio com propriedades mecânicas mais elevadas. Os primeiros experimentos ocorreram através de tentativas e erros, aliados a observações perspicazes, responsáveis pelo aprimoramento dos princípios metalúrgicos fundamentais envolvidos.

\subsection{Processo de obtenção do alumínio}

Para a obtenção do alumínio em escala industrial, nos dias atuais, empresas produtoras de bauxita grau metalúrgicas são integradas, produzindo desde o minério (bauxita), seguindo para a refinaria onde será produzida a alumina, posteriormente chegando à fundição onde será fabricado o alumínio primário, conforme figura 66 a seguir.

Figura 66 - Esquema produção integrada para obtenção do alumínio

\begin{tabular}{|llll} 
ESTRUTURA & MINA $\gg$ & REFINARIA $D$ & FUNDIÇÃO \\
Produto & bauxita $\sum$ & alumina & alumínio
\end{tabular}

Fonte: MARTIRES, 2007.

A bauxita, que denominamos de bauxita grau metalúrgica, é composta por no mínimo $55 \%$ de óxido de alumínio $\left(\mathrm{Al}_{2} \mathrm{O}_{3}\right)$, máximo de $7 \%$ 
de óxido de silício $\left(\mathrm{SiO}_{2}\right)$ reativa, $8 \%$ de óxido de férrico $\left(\mathrm{Fe}_{2} \mathrm{O}_{3}\right)$ - também conhecido como hematita - e $4 \%$ de óxido de titânio $\left(\mathrm{TiO}_{2}\right)$.

A bauxita também é empregada na indústria química, de abrasivos e de cimento. São as bauxitas grau não metalúrgica ou refratária (alta alumina), e composta em base calcinada em no mínimo 85\% (em peso) de óxido de alumínio $\left(\mathrm{Al}_{2} \mathrm{O}_{3}\right)$, máximo de $7 \%$ de óxido de silício $\left(\mathrm{SiO}_{2}\right)$ reativa, máximo $3,75 \%$ de óxido de férrico $\left(\mathrm{Fe}_{2} \mathrm{O}_{3}\right)$, e no máximo $3,75 \%$ de óxido de titânio $\left(\mathrm{TiO}_{2}\right)$, com densidade relativa de $3,1^{37}$.

As reservas de bauxita encontram-se localizadas em regiões tropicais e subtropicais e, de acordo com o International Aluminium Institut (IAI), em três principais tipos de clima: tropical (57\%), mediterrâneo (33\%) e o subtropical (10\%).

Os principais países produtores de bauxita são Austrália, China, Indonésia, Brasil, Guiné, Índia e Jamaica. Atualmente o Brasil ocupa a $4^{\mathrm{a}}$ posição no ranking da produção, atingindo 32.028 toneladas em $2010^{38}$. Possui também a terceira maior reserva mundial de bauxita, cujo potencial é da ordem de 2,5 bilhões de toneladas, concentrada principalmente na região Norte do país (estado do Pará), e sua principal concessionária é a Mineração Rio do Norte S.A. A empresa deverá atingir 18 milhões de toneladas/ano a partir de 2013. Nesse ranking também se destaca o desempenho da mina de Juriti (PA) da Alcoa Alumínio S.A, que já atingiu sua plena capacidade de produção.

As reservas brasileiras são caracterizadas por apresentarem aspectos tanto grau metalúrgico $(83,7 \%)$, bem como de grau não-metalúrgico ou refratário (16,3\%), e as reservas de bauxita no Brasil são do tipo trihidratado, enquanto as jazidas encontradas na França, Grécia e Hungria são do tipo mono-hidratados. É especialmente positivo esse fato, pois as plantas de alumina projetadas para utilizarem bauxitas tri-hidratadas exigem pressões e temperaturas mais baixas, o que implica custos de tratamentos menores. Além disso, apresentam características químicas que se enquadram nos padrões exigidos pelo mercado mundial.

\footnotetext{
${ }^{37}$ Densidade relativa - Razão entre a massa específica de um mineral e a massa específica da água destilada a $4{ }^{\circ} \mathrm{C}$.

${ }^{38}$ ABAL - Associação Brasileira do Alumínio. Anuário Estatístico da Associação Brasileira, 2010.
} 
Figura 67- Bauxita

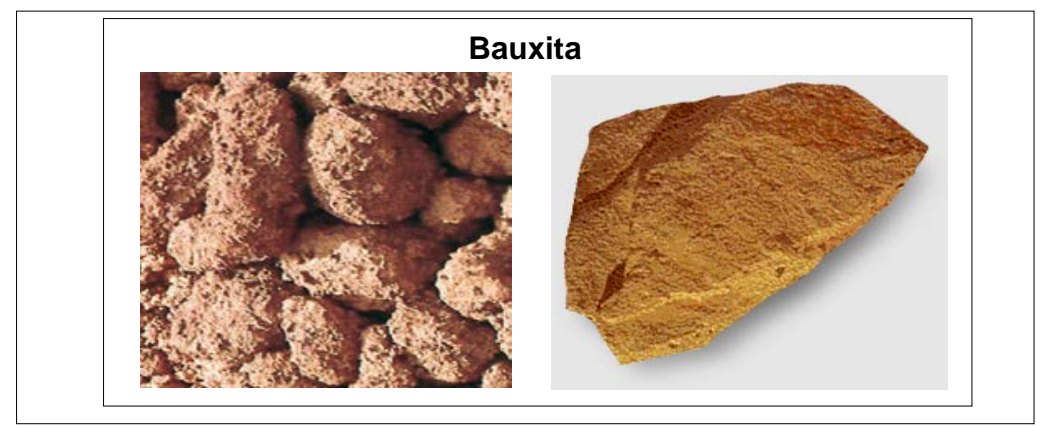

Fonte: CBA, 2011.

A bauxita deve apresentar no mínimo 30\% de alumina aproveitável, para que a produção de alumínio seja economicamente viável. O processo de obtenção de alumínio primário é feito a partir da bauxita e divide-se em três etapas: mineração, refinaria e redução.

Mineração - O alumínio não é encontrado diretamente em estado metálico na crosta terrestre. Sua obtenção depende de etapas de processamento até se alcançar o estado em que o vemos normalmente.

O processo da mineração da bauxita, que origina o alumínio, consiste na extração do minério propriamente dita. Antes da extração, a camada superior do solo e da vegetação (com espessura variando entre 10 e $50 \mathrm{~cm}$ ) é removida de forma planejada e armazenada, para uso posterior no processo de recuperação da área lavrada. A bauxita geralmente se encontra depositada próxima à superfície, com uma espessura variável, dependendo da sua formação geológica, ocorrendo geralmente em faixas que variam de 3 a 10 metros, o que possibilita a sua extração a céu aberto.

A extração (lavra) é efetuada utilizando-se retroescavadeiras hidráulicas, que permitem que se explore seletivamente o terreno a diferentes profundidades, para que haja o melhor aproveitamento possível do minério disponível e menor dano ao solo. O minério extraído é então transportado para a planta de beneficiamento, por carretas basculantes com capacidades que variam entre 10 e 30 toneladas.

As áreas mineradas são recuperadas após a conclusão da mineração. Procede-se então a sua reabilitação, de forma que retome da melhor maneira possível o seu estado natural. Atualmente, 60\% das áreas mineradas no Brasil para a extração da bauxita são totalmente reabilitadas, sendo a maior 
parte com a vegetação nativa. Assim, as indústrias de mineração promovem o uso temporário das terras, devolvendo-as recuperadas ao meio ambiente.

São construídas bancadas intermediárias para correção do relevo e poços de decantação para controle da erosão, e o solo original é então recolocado. Feito isso, inicia-se a reposição gradual da vegetação, através da inserção de gramíneas, espécies pioneiras e, finalmente, a vegetação perene, composta por árvores nativas, nobres e que obedecem aos contornos topográficos originais, minimizando os impactos ambientais.

Segundo dados de 1999 do International Aluminium Institut (IAI), a reabilitação de minas de bauxita em diversos climas, topografias e condições ecológicas obteve um grande progresso, sendo que $70 \%$ das áreas estão retornando à condição de floresta nativa, 17\% a pastagens e agricultura, 3\% a florestas comerciais, e os 10\% restantes são usados em áreas urbanas, habitacionais e recreativas. Esta pesquisa envolveu 27 localizações de minas, que representam $71 \%$ da produção mundial de bauxita e teve a participação de todas as mineradoras brasileiras.

O processo de beneficiamento ${ }^{39}$ da bauxita depende dos teores de concentração do minério, além de outras características, e pode incluir a britagem ${ }^{40}$, lavagem etc., para que se torne adequado ao processamento posterior. Essas atividades, aliadas ao emprego de ciclones e peneiras de alta frequência, permitem aproveitar ao máximo a bauxita contida no minério bruto e separar boa parte das impurezas, como argila, areia e outros resíduos.

Após a etapa de beneficiamento é necessário tratar os resíduos ${ }^{41} \mathrm{da}$ lama resultante das atividades de mineração da bauxita, que se apresenta sob a forma de uma polpa alcalina, contendo partículas sólidas. Por esse motivo, sua disposição exige cuidados especiais para evitar a contaminação das águas superficiais e subterrâneas.

Para assegurar a proteção do solo e dos mananciais ${ }^{42}$ subterrâneos, são construídos próximo à refinaria lagos de resíduos de bauxita que são revestidos internamente por dupla camada de impermeabilizante (argila e

\footnotetext{
${ }^{39}$ Beneficiamento - Fazer a beneficiação de produtos, como os metais.

${ }^{40}$ Britagem - É o processo primário de trituração, fragmentação ou moagem de materiais rochosos (carvão, minério). Ato ou ação usada para reduzir sólidos a partículas diminutas.

${ }^{41}$ Resíduos - O que resta de substâncias submetidas à ação de diversos agentes.

${ }^{42}$ Mananciais - Nascente de água, origem ou fonte abundante, celeiro inesgotável.
} 
$\mathrm{PVC}^{43}$ ). Sistemas de drenagem de fundo permitem recolher a água com soda, bombeando-a para ser reciclada no processo. No sistema de drenagem superficial, a água neutralizada é lançada ao meio ambiente.

No processo seguinte ao beneficiamento, a bauxita é disposta em pilhas de homogeneização, através de correias transportadoras e de empilhadeiras automáticas. Essas pilhas permitem a equalização de propriedades entre lotes de minério proveniente de diversas frentes de mineração. Após o beneficiamento e homogeneização ${ }^{44}$, o minério é transportado para a fábrica por via férrea, em vagões apropriados.

Os carregamentos chegam às fábricas provenientes das áreas de mineração. Nesse ponto, obtém-se bauxita com teores médios em cerca de $3,5 \%$ de sílica reativa, $42 \%$ a $43 \%$ de alumina aproveitável e a granulometria $^{45}$ (tamanho médio das pedras do minério) abaixo de duas polegadas $^{46}(5 \mathrm{~cm})$, características adequadas à fase de processamento que se inicia.

Refinaria - A alumina, óxido de alumínio de alta pureza, é o resultado do processamento químico da bauxita conhecido como processo Bayer ${ }^{47}$.

Essa operação se realiza em uma fábrica denominada refinaria, onde o minério é transformado em alumina calcinada, que será utilizada no processo eletrolítico subsequente, como o principal insumo para a produção de alumínio. O minério segue então para moagem nos moinhos de bola.

\footnotetext{
${ }^{43}$ PVC - Policloreto de polivinila (também conhecido como cloreto de vinila ou policloreto de vinil; nome IUPAC policloroeteno): mais conhecido pelo acrónimo PVC (da sua designação em inglês Polyvinyl chloride) é um plástico não 100\% originário do petróleo.

${ }^{44}$ Homogeneização - Ação de homogeneizar.

${ }^{45}$ Granulometria - A parte sólida dos solos é composta por um grande número de partículas que possuem diferentes dimensões; é possivel determinar faixas pré-estabelecidas de tamanho de grãos, conhecidas por análise granulométrica.

${ }^{46}$ Polegadas - Menor unidade de distância no sistema de medidas dos países anglosaxônicos. Qualquer distância menor que uma polegada é medida em frações de polegada. Já o sistema métrico utiliza pequenas distâncias em centímetros e milímetros. Uma polegada equivale a $2,54 \mathrm{~cm}$. O símbolo da polegada é ".

${ }^{47}$ Processo Bayer é o principal método industrial para produzir alumina a partir de bauxita. Patenteado pelo austriaco Karl Bayer, em 1889, e baseado na dissolução da bauxita com hidróxido sódico, este processo foi se impondo até converter-se, a partir dos anos 1960, na única fonte industrial de alumina e, portanto, de alumínio no mundo.
} 
Nesse processo, acrescenta-se soda cáustica, cal e água à bauxita, obtendose uma mistura pastosa, a pasta densa.

Essa mistura segue para as autoclaves para cozimento. Nessa fase ocorre a formação do aluminato de sódio ${ }^{48}$, composto instável obtido a partir da reação entre a soda cáustica e a alumina. Após a filtragem, decantação e diminuição da temperatura do composto, ocorrem a separação da soda cáustica e a formação do hidróxido de alumínio, ou hidrato, de alta pureza.

A soda cáustica recuperada é reaproveitada no processo. O hidrato segue então para o forno de calcinação, onde é transformado em alumina, o óxido de alumínio.

Figura 68 - Fases da produção de alumina - da entrada do minério à saída do produto.

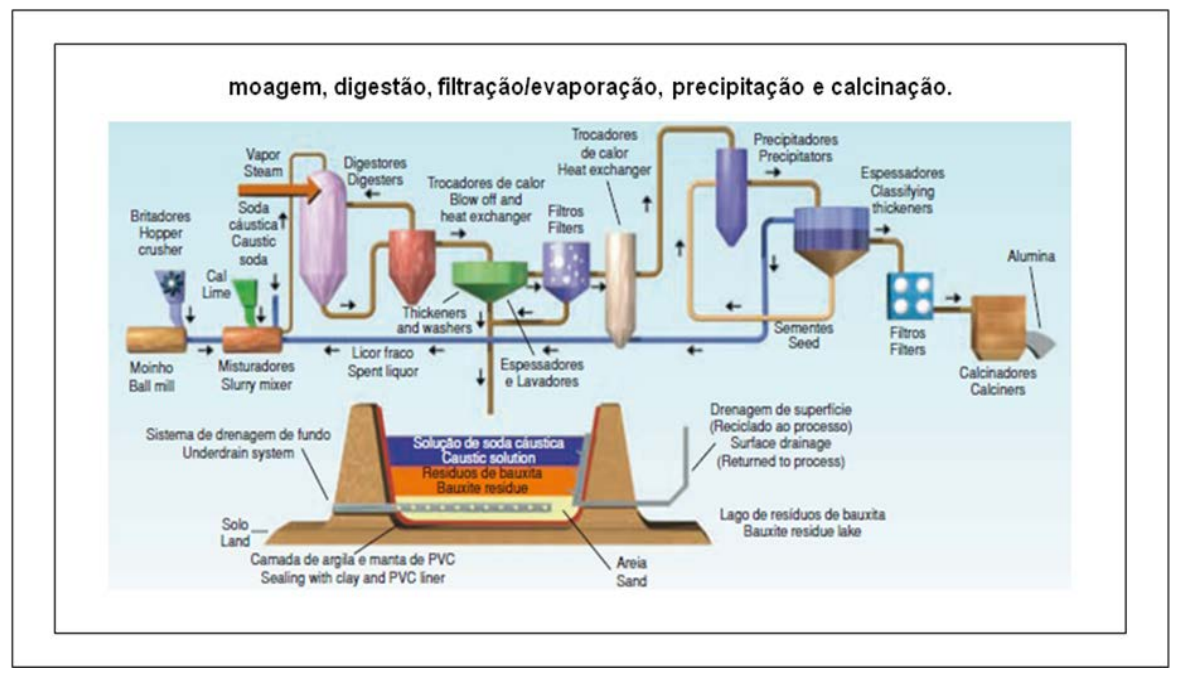

Fonte: ABAL, 2010.

Além da bauxita e de combustíveis energéticos, a produção de uma tonelada de alumina requer outros insumos, cujo consumo depende da qualidade do minério. A Tabela 25, exposta a seguir, apresenta os parâmetros do consumo de outros insumos.

\footnotetext{
${ }^{48}$ Aluminato de sódio - É um composto químico inorgânico de grande importância industrial. Ele constitui uma fonte de hidróxido de alumínio utilizado em um grande número de aplicações técnicas. Na forma anidra, é um sólido cristalino branco, óxido misto de sódio e de alumínio, de fórmula química $\mathrm{Na}_{2} \mathrm{Al}_{2} \mathrm{O}$.
} 
Tabela 25 - Parâmetros do consumo de alumina

\begin{tabular}{|l|l|}
\hline Bauxita $(\mathrm{t} / \mathrm{t})$ & 1,85 a 3,4 \\
\hline Cal $(\mathrm{kg} / \mathrm{t})$ & 10 a 50 \\
\hline Soda cáustica $(\mathrm{kg} / \mathrm{t})$ & 40 a 140 \\
\hline Vapor $(\mathrm{t} / \mathrm{t})$ & 1,5 a 4,0 \\
\hline Óleo combustível - calcinação $(\mathrm{kg} / \mathrm{t})$ & 80 a 130 \\
\hline Floculante sintético $(\mathrm{g} / \mathrm{t})$ & 100 a 1000 \\
\hline Energia elétrica $(\mathrm{kwh} / \mathrm{t})$ & 150 a 400 \\
\hline Produtividade $(\mathrm{Hh} / \mathrm{t})$ & 0,5 a 3,0 \\
\hline Água $\mathrm{m}^{3} / \mathrm{t}$ & 0,5 a 2,0 \\
\hline
\end{tabular}

Fonte: Associação Brasileira de Alumínio (ABAL), 2010.

Redução - Redução do alumínio é o processo de transformação da alumina em alumínio metálico. A alumina é dissolvida em um banho de criolita $^{49}$ fundida e fluoreto de alumínio em baixa tensão, decompondo-se em oxigênio. Este último se combina com o ânodo de carbono, desprendendo-se na forma de dióxido de carbono e em alumínio líquido, que se precipita no fundo da cuba eletrolítica. Após esse processo, o metal líquido (já alumínio primário) é transferido para a refusão através de cadinhos ${ }^{50}$. O alumínio sai das cubas no estado líquido, a aproximadamente $850^{\circ} \mathrm{C}$, e é então transportado para a fundição, onde são ajustadas a sua composição química e forma física. As Figuras 69 e 70 a seguir explicitam o processo de redução.

São necessárias cerca de cinco toneladas de bauxita para produzir duas toneladas de alumina, e duas toneladas de alumina para produzir uma tonelada de alumínio pelo processo de redução.

${ }^{49}$ Criolita: Mineral fluoreto de sódio e alumínio $\left(\mathrm{Na}_{3} \mathrm{AlF}_{6}\right)$.

${ }^{50}$ Cadinhos: Vasos metálicos utilizados em operações químicas, a temperaturas elevadas. 
Figura 69 - Salas de cubas.

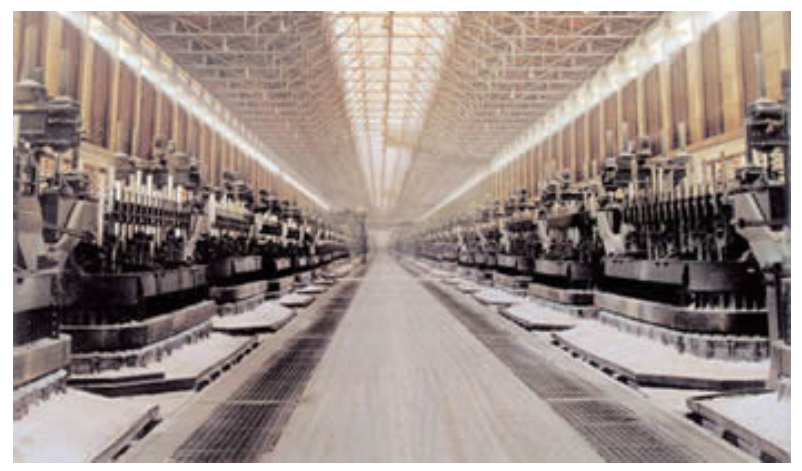

Fonte :ABAL,2010.

Figura 70 - Célula de redução.

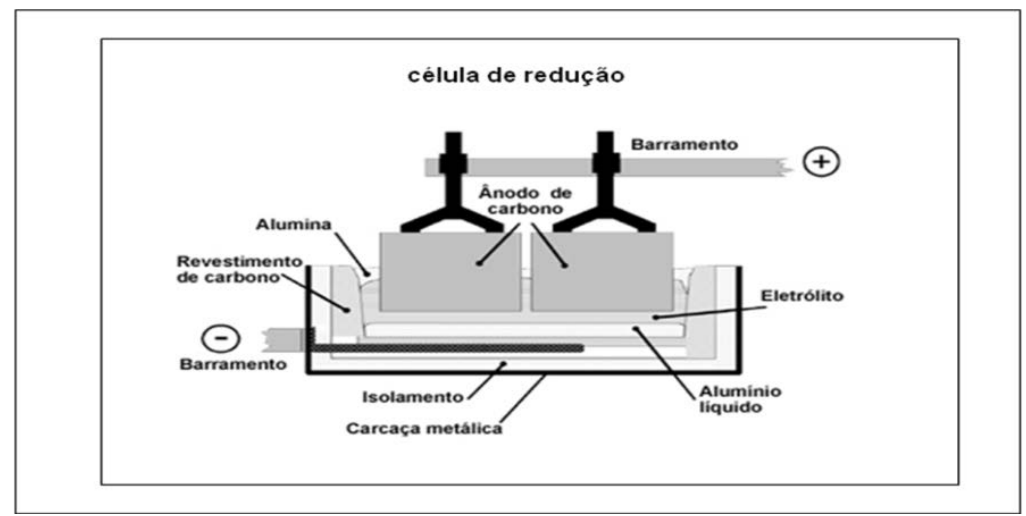

Fonte:ABAL,2010

Os principais insumos ${ }^{51}$ para a produção de alumínio primário durante o processo de redução são descritos na Tabela 26, a seguir.

Tabela 26 - Insumos para a produção de alumínio primário (ano-base 2010)

\begin{tabular}{|l|c|}
\hline Alumina (1.000 toneladas) & 2860,0 \\
\hline Energia elétrica (GWh) & 23982,0 \\
\hline Criolita (1.000 toneladas) & 8,2 \\
\hline Fluoreto de alumínio (1.000 toneladas) & 33,9 \\
\hline Coque de petróleo (1.000 toneladas) & 550,6 \\
\hline Piche (1.000 toneladas) & 172,4 \\
\hline
\end{tabular}

\footnotetext{
${ }^{51}$ Insumos - O que entra como matéria-prima, força de trabalho, consome de energia etc, para se conseguir um produto.
} 
Fonte: ABAL, 2010.

\subsection{Propriedades físicas e químicas}

As características e propriedades do alumínio o tornam um dos mais versáteis materiais utilizados na construção civil e indústrias de quase todos os segmentos.

O ponto de fusão do alumínio puro $\left(99,80 \%\right.$ de pureza) é de $660^{\circ} \mathrm{C}$, valor considerado relativamente baixo se comparado com o ponto de fusão do aço, que é da ordem de $1.570^{\circ} \mathrm{C}$.

Ligas de alumínio, devido à presença de outros metais, possuem, em geral, um ponto de fusão ${ }^{52}$ mais baixo que o do alumínio puro. A liga 6060, com aproximadamente $2 \%$ de elementos de liga, funde-se à temperatura entre $600^{\circ} \mathrm{C}$ e $650^{\circ} \mathrm{C}$, enquanto a liga 7075 , com aproximadamente $10 \%$ de liga, funde-se à temperatura entre $475^{\circ} \mathrm{C}$ e $640^{\circ} \mathrm{C}$.

A leveza é uma das principais propriedades do alumínio. Seu peso específico é de cerca de $22,70 \mathrm{~g} / \mathrm{cm}^{3}$, aproximadamente $35 \%$ do peso do aço e $30 \%$ do peso do cobre. Essa característica, aliada ao aumento da resistência mecânica por adição de elementos de liga e tratamentos térmicos, torna o alumínio o material com significativa indicação às indústrias da aeronáutica e de transportes.

Com relação à resistência mecânica, o alumínio comercialmente puro apresenta resistência à tração de aproximadamente $90 \mathrm{MPa}^{53}$. Sua utilização como material estrutural nesta condição é limitada. Entretanto, sua resistência mecânica pode ser praticamente dobrada por meio do trabalho a frio. Aumentos maiores na sua resistência podem ser obtidos com pequenas adições de outros metais como elementos de liga, como silício, cobre manganês, magnésio, cromo, zinco, ferro, zircônio, lítio, estanho etc.

\footnotetext{
${ }^{52}$ Ponto de fusão - Designa a temperatura a qual uma substância passa do estado sólido ao estado líquido.

${ }^{53} \mathrm{MPa}$ - Megapascais, unidade-padrão de pressão e tensão no Sistema Internacional de Unidades - SI.
} 
Tabela 27 - Propriedades do alumínio

\begin{tabular}{|l|c|}
\hline Número atômico: & 13 \\
\hline Peso atômico: & $2,70 \mathrm{~g} / \mathrm{cm}^{3}$ \\
\hline Ponto de fusão: & $660^{\circ} \mathrm{C}$ \\
\hline Ponto de ebulição: & $2.467^{\circ} \mathrm{C}$ \\
\hline Limite de resistência (recozido) & $4,8 \mathrm{kgf} / \mathrm{mm}^{2}$ \\
\hline Limite de escoamento (recozido) & $1,0 \mathrm{kgf} / \mathrm{mm}^{2}$ \\
\hline Alongamento (recozido) & $65 \%$ \\
\hline Densidade $\left(20^{\circ} \mathrm{C}\right)$ & $2,702 \mathrm{kgf} / \mathrm{dm}^{3}$ \\
\hline Contração na ebulição & $6,6 \%$ \\
\hline Contração do ponto de fusão (até $\left.20^{\circ} \mathrm{C}\right)$ & $5,6 \%$ \\
\hline Condutividade térmica a $25^{\circ} \mathrm{C}$ & $0,53 \mathrm{cal} / \mathrm{cm}^{\circ} \mathrm{C}$ \\
\hline Refletividade & $24 \%-83 \%$ \\
\hline Estados de oxidação: & 3 \\
\hline
\end{tabular}

Fontes: ABAL, 2011.

Assim como o alumínio puro, as ligas não tratáveis ${ }^{54}$ podem também aumentar sua resistência por meio do trabalho a frio. Já as ligas tratáveis ${ }^{55}$ podem ainda apresentar aumento de resistência, por meio de tratamento térmico. Algumas ligas chegam a ter resistência à tração de aproximadamente $700 \mathrm{MPa}$.

O alumínio puro possui resistividade de 0,00000263 ohms $/ \mathrm{cm}^{356}$ e condutividade elétrica de $62 \%$ da International Annealed Copper Standard (IACS), a qual, associada à sua baixa densidade, significa que um condutor de alumínio pode conduzir tanta corrente quanto um condutor de cobre, que é duas vezes mais pesado e proporcionalmente mais caro.

A alta condutividade térmica do alumínio torna-o um dos metais mais usados na fabricação de utensílios domésticos. Essa característica é importante meio de transferência de energia térmica, tanto no aquecimento quanto no resfriamento. Assim, os trocadores ou dissipadores de calor em alumínio são comuns nas indústrias alimentícias, químicas, petrolíferas, aeronáuticas etc. O alumínio é também um excelente refletor de energia radiante, devido ao grande alcance dos comprimentos de onda ${ }^{57}$ desde os raios ultravioletas, dentro dos espectros visíveis, até os raios infravermelhos e onda de calor, tanto quanto ondas eletromagnéticas de rádio e radar. $\mathrm{O}$

\footnotetext{
${ }^{54}$ Ligas não tratáveis - Não são endurecidas por meio de tratamento térmico.

${ }^{55}$ Ligas tratáveis- São endurecidas por meio de tratamento térmico.

${ }^{56} \mathrm{Ohms} / \mathrm{cm}^{3}$ - Resistividade elétrica. Unidade ohm metro $(\Omega \mathrm{m})$.

${ }^{57}$ Comprimentos de onda $(\lambda)$ : Distância, medida na direção de propagação de uma onda periódica, entre dois pontos sucessivos no quais a fase é a mesma. Unidade: metro (m).
} 
alumínio puro possui uma condutibilidade térmica $(k)$ 4,5 vezes maior que a do aço.

O alumínio novo, não oxidado, tem refletividade acima de $80 \%$, o que permite ampla utilização em coberturas e sistemas óticos e refletores utilizados na produção de luminárias. Coberturas de alumínio refletem alta porcentagem dos raios incidentes do sol. Assim, edificações cobertas com este material proporcionam melhores condições de conforto térmico interno dos ambientes.

Importante elemento de barreira à luz, o alumínio também é impermeável à ação da umidade e do oxigênio. A indústria de iluminação adota o processo de anodização, resultante da ação combinada de um tratamento mecânico e/ou químico sobre a superfície do alumínio, com a intenção de maximizar a refletividade ${ }^{58}$ e obter uma boa aparência superficial.

A característica nuclear do alumínio representa propriedade de importância na engenharia nuclear, por sua baixa absorção de nêutrons. Tal propriedade não impede significativamente a passagem dessas partículas que mantêm a reação nuclear no combustível de urânio -, tornando-o um material eficiente e de uso intensivo no núcleo dos reatores de baixa temperatura.

Por possuir características não tóxicas, o alumínio é utilizado em utensílios domésticos sem causar qualquer efeito nocivo ao organismo humano. Pelo mesmo motivo, é muito utilizado em embalagens das indústrias alimentícia e farmacêutica.

O alumínio não é ferromagnético (característica importante para aplicações eletroeletrônicas); o alumínio líquido tem baixa emissividade ${ }^{59}$, funcionando como material isolante em algumas aplicações. O metal apresenta baixa viscosidade 60 ou alta fluidez, o que lhe permite fluir facilmente por meio de pequenas aberturas e fissuras, mesmo com baixa

\footnotetext{
${ }^{58}$ Refletividade - Capacidade foto energética de filtrar raios luminosos através da reflexão da radiação

${ }^{59}$ Emissividade - Proporção entre a quantidade de calor irradiado pela superfície de um corpo dado e a de um corpo negro de superfície e temperatura idêntica, cujo poder de emissão serve de unidade.

${ }^{60}$ Viscosidade - É causada pelo atrito interno das moléculas do fluido, em movimento umas contra as outras.
} 
pressão de vazamento. A viscosidade do alumínio, na temperatura normal de fundição, é quase a mesma da viscosidade da água à temperatura ambiente.

Material de alta reatividade química, o alumínio líquido tem sua atividade aumentada com a elevação da temperatura, e combina quimicamente com muitas substâncias, liberando grande quantidade de energia e calor.

Muitas aplicações requerem extrema versatilidade que somente o alumínio possui. A combinação de suas propriedades permite novas aplicações. A Tabela 28 apresenta uma comparação entre as características dos três metais mais utilizados pela sociedade contemporânea.

Tabela 28 - Propriedades físicas típicas do alumínio/ aço/cobre.

\begin{tabular}{|l|l|l|l|}
\hline Propriedades físicas típicas & Alumínio & Aço & Cobre \\
\hline Densidade $\left(\mathrm{g} / \mathrm{cm}^{3}\right)$ & 2,7 & 7,86 & 8,96 \\
\hline Temperatura de fusão $\left({ }^{\circ} \mathrm{C}\right)$ & 660 & 1500 & 1083 \\
\hline Módulo de elasticidade $(\mathrm{MPa})$ & 70000 & 205000 & 110000 \\
\hline Condutibilidade térmica a $25^{\circ} \mathrm{C}\left(\mathrm{Cal} / \mathrm{cm} /{ }^{\circ} \mathrm{C}\right)$ & 0,53 & 0,12 & 0,94 \\
\hline Condutibilidade elétrica a $25^{\circ} \mathrm{C}(\% \mathrm{IACS})$ & 61 & 14,5 & 100 \\
\hline
\end{tabular}

Fonte: ABAL, 2010.

\subsection{Processos industriais}

O alumínio é facilmente fabricado por todos os processos metalúrgicos usuais e está disponível em uma ampla variedade de formas, comparadas a outros materiais. O alumínio pode ser fundido por qualquer método conhecido, pode ser laminado em qualquer espessura até folhas mais finas que as de papel, e chapas de alumínio podem ser estampadas, cunhadas, repuxadas e corrugadas. Pode ser extrudado numa infinidade de perfis, forjado ou impactado.

Fundição - A fundição ${ }^{61}$ é o ponto de partida para a fabricação de todos os produtos. É lá também que se preparam as diferentes ligas de alumínio, destinadas a diferentes tipos de produtos e aplicações.

${ }^{61}$ Fundição - Ação ou efeito de fundir metais. Fábrica onde eles se fundem. 
Nessa fase, são produzidos lingotes, tarugos, placas e vergalhões, em ligas de propriedades especialmente adequadas a aplicações especiais e a processos específicos de fabricação.

A principal matéria-prima utilizada na fundição é o alumínio primário, vindo diretamente das salas fornos, no estado líquido, a aproximadamente $850{ }^{\circ} \mathrm{C}$. Ele é introduzido nos fornos de fusão, por meio de cadinhos com capacidade média de cinco toneladas. O alumínio puro recebe então a adição de outros elementos para a formação das ligas.

Figura 71 - Vazamento de liga de alumínio

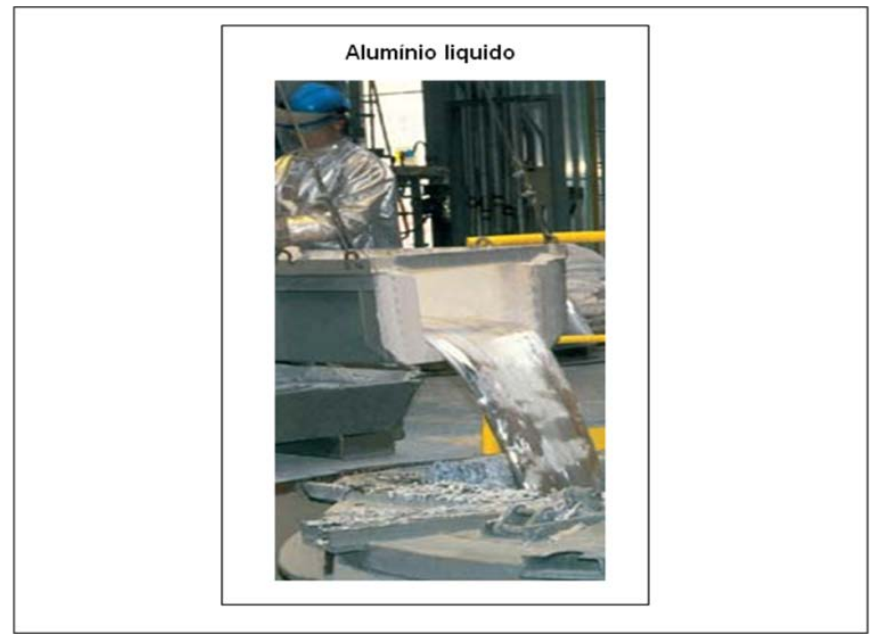

Fonte: ABAL, 2011.

A fundição foi um dos primeiros processos industriais utilizados na produção de artigos de metal. As propriedades do alumínio e a tecnologia moderna oferecem excelentes condições, com controles científicos adequados, para que se possam produzir grandes quantidades de peças mantendo uma qualidade uniforme. O mercado conta com excelentes ligas de alumínio, que proporcionam uma grande variedade de propriedades para as peças fundidas. As principais propriedades são a baixa temperatura de fusão, a forte tendência à oxidação, a baixa densidade, a alta condutividade térmica e o elevado coeficiente de dilatação.

Para grandes volumes de peças, a fundição em matriz sob pressão é a mais utilizada. O metal é forçado a penetrar em matrizes de aço sob a força 
de pressão hidráulica. Os fundidos com grande precisão de detalhes são produzidos desta forma.

As peças fundidas de alumínio têm suas principais aplicações na área automotiva e de transportes, que representam cerca de $60 \%$ do consumo do alumínio neste segmento. Como exemplo, temos os blocos de motor, caixas de câmbio, carcaça de motores e rodas para automóveis e veículos pesados, entre outros.

$\mathrm{Na}$ fundição são produzidos lingotes, tarugos, placas, vergalhões e chapas. Esses produtos tanto se destinam à comercialização, à utilização e na fabricação de produtos laminados, extrudados ${ }^{62}$ e cabos.

\subsubsection{Sistema de classificação do alumínio e suas ligas}

As ligas de alumínio são bastante utilizadas em diversas aplicações industriais, graças à sua elevada resistência e solidez. O cobre, o magnésio e o silício são alguns dos elementos que mais se apresentam a formar liga com o alumínio. Esse tipo de combinação, de que existem inúmeras variedades, é a chamada liga leva. Entre as de maior interesse industrial, cabe mencionar o duralumínio (de Düren), formado por $93,2 \%$ a $95,5 \%$ de alumínio, $3,5 \%$ a $5,5 \%$ de cobre, $0,5 \%$ a $0,8 \%$ de magnésio e, em alguns tipos, silício.

As ligas de alumínio e magnésio são empregadas na construção naval, graças à sua elevada resistência à corrosão e soldabilidade; e as ligas de alumínio e silício desempenham papel importante na indústria automobilística, devido à sua elevada resistência mecânica e peso reduzido, assim como na fabricação de componentes elétricos.

A tradicional liga de alumínio, o duralumínio (conhecida também como alumínio-cobre-magnésio), pode ser endurecido por um tratamento estrutural (maturação ou envelhecimento) que a torna utilizável na fabricação de automóveis e aviões. Outras ligas, com cobre-níquel, com magnésio (alumig), com magnésio-zinco (zicral), sofrem igualmente esse tratamento térmico característico. Em forma de peças de fundição, a liga de alumínio-

${ }^{62}$ Extrudado- É o produto obtido no processo de extrusão. 
silício (alpax) é utilizada na produção de blocos de motores de êmbolos de automóveis.

Para a obtenção dessas ligas é necessário utilizar um alumínio de alta pureza $(99,99 \%)$, requisito que tem levado ao desenvolvimento de diversos processos de obtenção desse metal, todos baseados na redução da alumina extraída da bauxita.

As ligas de alumínio são divididas e subdivididas em dois grupos:

- Ligas conformadas ou trabalhadas (wrought alloys) - ligas destinadas à fabricação de produtos semiacabados, como laminados planos (placas, chapas e folhas), laminados não planos (tarugos, barras e arames), perfis extrudados e componentes forjados.

- Ligas fundidas (cast alloys) - ligas destinadas à fabricação de componentes fundidos.

Somando-se as ligas conformadas e as ligas fundidas, existem mais de 600 ligas reconhecidas industrialmente e subdivididos em dois grupos:

- Liga não tratável - Não são endurecidas por meio de tratamento térmico.

- Liga tratável termicamente - São endurecidas por meio de tratamentos térmicos.

Nomenclaturas de ligas conformadas, como exemplificado:

- 1XXX - Alumínio puro não ligado, com 99,00\% mínimo de Alumínio (Al).

- 2XXX - Ligas contendo Cobre (Cu) como elemento de liga principal e adições de outros elementos, principalmente Magnésio (Mg).

- 3XXX - Ligas contendo Manganês (Mn) como elemento de liga principal.

- $4 X X X$ - Ligas contendo Silício (Si) como elemento de liga principal.

- 5XXX - Ligas contendo Magnésio (Mg) como elemento de liga principal. 
- 6XXX - Ligas contendo Magnésio (Mg) e Silício (Si) como elementos principais de liga.

- 7XXX - Ligas contendo Zinco (Zn) como elemento de liga principal e adições de Cobre (Cu), Magnésio (Mg), Cromo (Cr) e Zircônio (Zr).

- 8XXX- Ligas cujas composições apresentam diferentes elementos, como Estanho (Sn) ou Lítio (Li).

- 9XXX - reservada para uso futuro.

Para identificá-las, seguimos as seguintes nomenclaturas:

Na série $1 \mathrm{XXX}$, os dois últimos dígitos indicam a \% de Al acima de $99 \%$.

- $\quad$ Liga $1050-99,50 \%$ de Al
- $\quad$ Liga $1060-99,60 \%$ de Al

O segundo dígito indica modificações no limite de impurezas ou a adição de outro elemento na liga. Se o segundo dígito for 0 (zero), indica que o alumínio (Al) não foi ligado e apresenta o limite de impureza convencional. Os números entre 1 (um) e 9 (nove) indicam controle especial sobre uma ou mais impurezas ou a adição de elementos de liga.

Nas séries $2 \mathrm{XXX}$ a $8 X X X$, os dois últimos dígitos não possuem significado numérico, apenas identificam diferentes ligas do mesmo grupo (número sequencial). O segundo dígito indica modificações no limite de impurezas ou a adição de elementos de liga. Ligas experimentais também utilizam este sistema de classificação, porém, são indicadas pelo prefixo $X$. 
Figura 72 - Classificação do alumínio e suas ligas

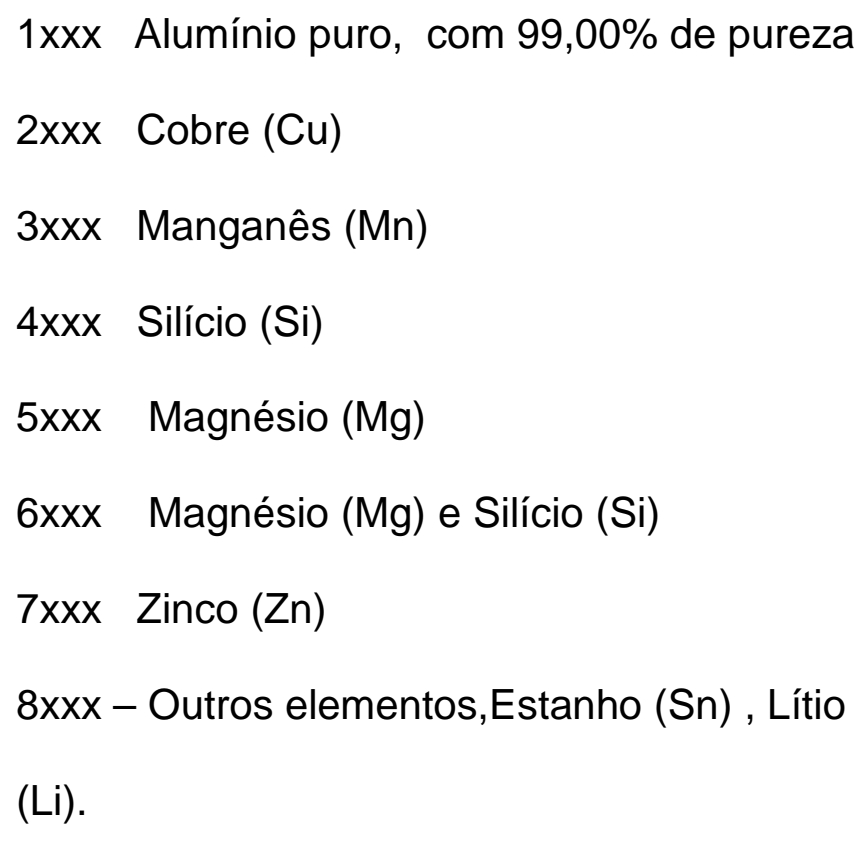
(Li).

Fonte: ABAL, 2010.
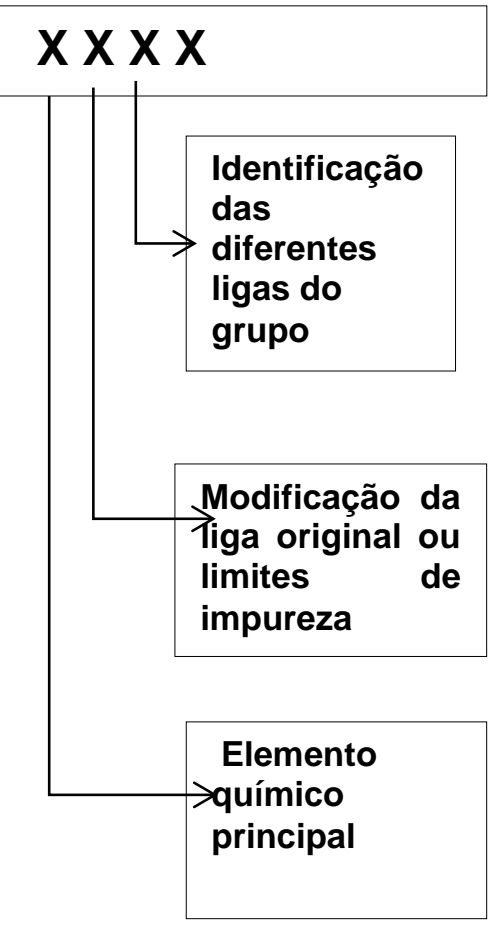

Laminação - A produção de laminados ${ }^{63}$ é denominada laminação. É um processo de transformação mecânica que consiste na redução da seção transversal por compressão do metal, por meio da passagem entre dois cilindros de aço ou ferro fundido com eixos paralelos que giram em torno de si mesmos. Esta seção transversal é retangular e se refere a produtos laminados planos de alumínio e suas ligas, compreendendo desde chapas grossas com espessuras de $150 \mathrm{~mm}$, usadas em usinas atômicas, até folhas com espessura de 0,005 mm, usadas em condensadores.

Existem dois processos tradicionais de laminação de alumínio: laminação a quente e laminação a frio.

Atualmente, a indústria também se utiliza da laminação contínua.

\footnotetext{
${ }^{63}$ Laminado - Produto proveniente de um processo de transformação mecânica por compressão (laminação).
} 
Figura 73 - Processo de laminação

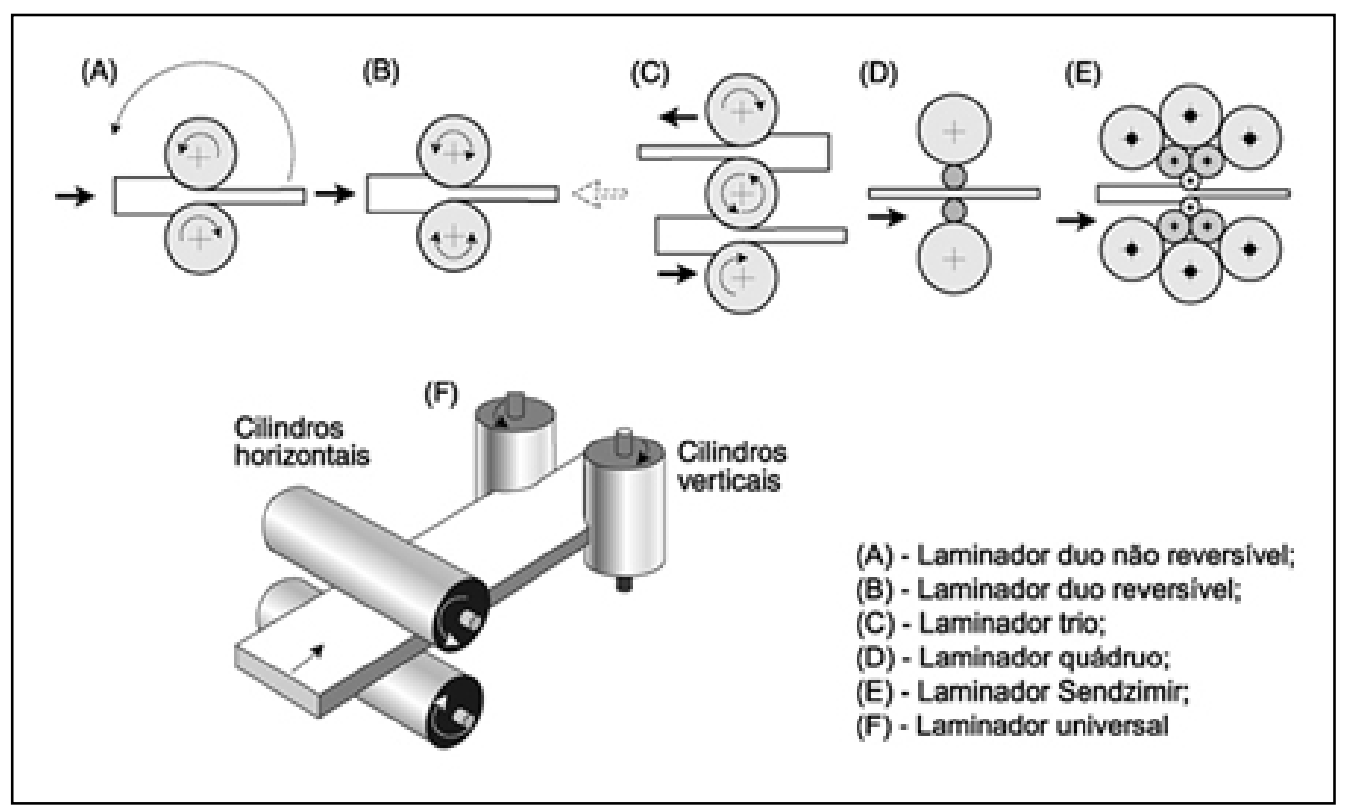

Fonte: ABAL, 2011.

A laminação a quente promove reduções da seção transversal com o metal a uma temperatura mínima de aproximadamente $350^{\circ} \mathrm{C}$ (igual à temperatura de recristalização ${ }^{64}$ do alumínio). A ductilidade ${ }^{65}$ do metal a temperaturas desta ordem é máxima e, nesse processo ocorre à recristalização dinâmica na deformação plástica.

A matéria-prima inicial é uma placa, cujo peso varia de alguns quilos até 15 toneladas; é produzida na refusão, por meio de fundição semicontínua, em molde com seção transversal retangular. Este tipo de fundição assegura a solidificação ${ }^{66}$ rápida e estrutura metalúrgica homogênea. A placa pode sofrer uma usinagem superficial, para remoção da camada de óxido de alumínio, dos grãos colunares e das impurezas provenientes da fundição. Posteriormente, a placa é aquecida até tornar-se semiplástica.

A laminação a quente se processa em laminadores reversíveis duplos, com dois cilindros ou quádruplos, com dois cilindros de trabalho e

\footnotetext{
${ }^{64}$ Recristalização - Formação de uma nova estrutura de granulação pelo aquecimento de material trabalhado a frio.

${ }^{65}$ Ductilidade - Propriedade de um material de deforma-se mecanicamente, sem chegar à ruptura.

${ }^{66}$ Solidificação - Passagem de um corpo do estado líquido para o estado sólido.
} 
dois de apoio ou encosto. O material laminado é deslocado, a cada passada, por entre os cilindros, sendo que a abertura dos mesmos define a espessura do passe. A redução da espessura por passe é de aproximadamente $50 \%$ e depende da dureza da liga que está sendo laminada. No último passe de laminação, o material apresenta-se com espessura ao redor de $6 \mathrm{~mm}$, sendo enrolado ou cortado em chapas planas, constituindo-se na matéria-prima para o processo de laminação a frio.

Figura 74- Processo de laminação a frio

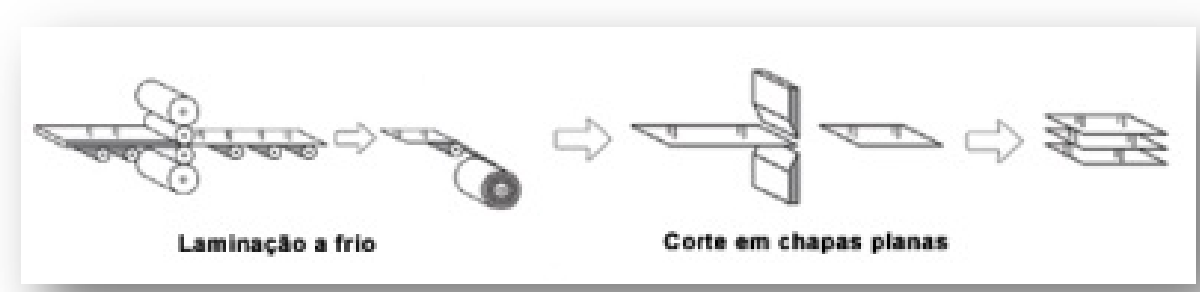

Fonte: ABAL, 2011.

Figura 75 - Processo de laminação a quente

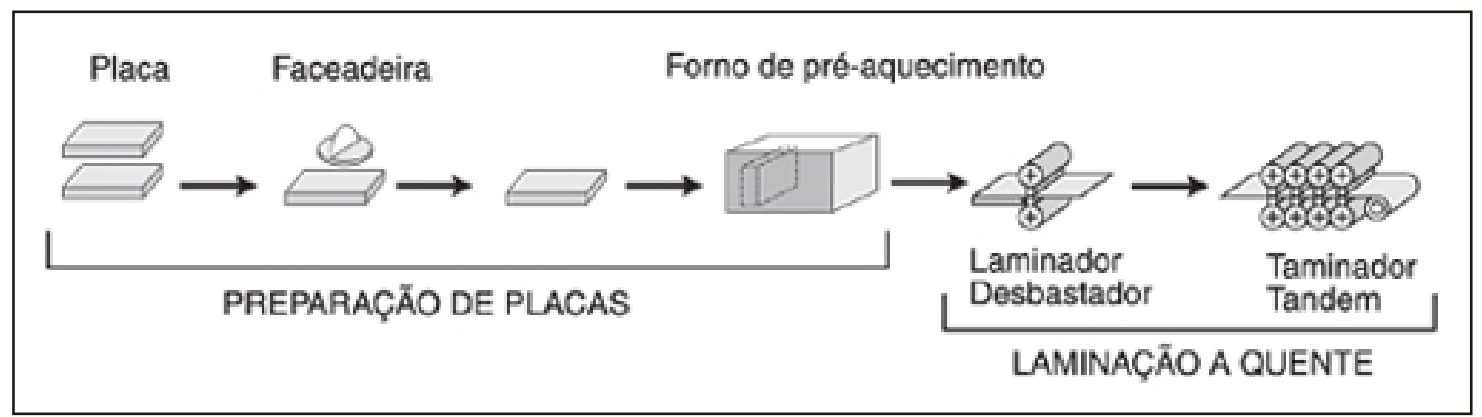

Fonte: ABAL, 2011.

Uma unidade de laminação a quente contém laminador, refusão ${ }^{67}$, fornos de preaquecimento para placas, tratamentos térmicos de homogeneização (distribuição mais homogênea dos elementos microconstituintes químico-metalúrgicos), tesouras rotativas e guilhotinas

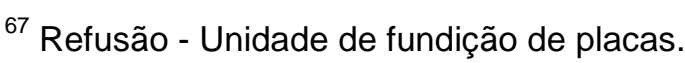


para cortes laterais e longitudinais ${ }^{68}$ do material laminado, serras para cortes das extremidades e faceadeira para usinagem das superfícies.

A laminação a frio é realizada a temperaturas bem inferiores às de recristalização do alumínio. A matéria-prima ${ }^{69}$ é oriunda da laminação a quente. A laminação a frio é executada, geralmente, em laminadores quádruplos, reversíveis ou não, sendo este último mais empregado. O número de passes depende da espessura inicial da matéria-prima, da espessura final, da liga e da têmpera do produto desejado. Os laminadores estão dimensionados para reduções de seções entre 30\% e 70\% por passe, dependendo, também, das características do material em questão. Laminadores mais sofisticados possuem sistemas computadorizados de controle de espessura e de planicidade.

Na laminação a frio são utilizados dois recursos: tensões avante e tensões a ré. Ambas aliviam o esforço de compressão exercido pelos cilindros ou aumentam a capacidade de redução por passe. Estes recursos são também responsáveis pela redução da espessura, no caso de laminação de folhas finas, em que os cilindros de laminação estão em contato e praticamente sem abertura perceptível. A deformação a frio confere encruamento ao alumínio e aumenta os limites de resistência à tração e ao escoamento, com diminuição do alongamento. Esse procedimento produz um metal com bom acabamento superficial e preciso controle dimensional.

Os produtos laminados de alumínio são utilizados em todas as operações metalúrgicas usuais de chapas, incluindo aquelas que exigem do metal de excepcional ductilidade, como é o caso de processos como estampagem ${ }^{70}$, extrusão por impacto, perfilação ${ }^{71}$ etc.

Recozimentos $^{72}$ intermediários podem ser realizados para amolecimento (recristalização), para facilitar posterior laminação ou

\footnotetext{
${ }^{68}$ Longitudinais - No sentido do comprimento.

${ }^{69}$ Matéria-prima - Substância com que se fabrica alguma coisa.

${ }^{70}$ Estampagem - Processo metalúrgico que consiste na deformação plástica por tração a frio, com o objetivo de endireitar ou dar planicidade ao material (NBR 6599).

${ }^{71}$ Perfilação - Processo de conformação progressiva por calandras ou roletes, de produtos laminados planos, sem modificações apreciáveis da espessura (NBR 6599).

72 Recozimentos- É aplicável tanto para ligas tratáveis como para as não-tratáveis termicamente. É o tratamento térmico destinado a amolecer o material para a eliminação total de tensões resultantes de deformações plásticas a frio ou pela anulação dos efeitos de tratamentos térmicos anteriores (NBR 6835).
} 
determinar têmperas específicas. Os produtos laminados a frio mais finos (folhas), com espessura de até 0,005 mm, são produzidos em laminadores específicos, que concebem o processo de laminação de folhas duplas com lubrificação entre elas.

Outro processo atualmente muito utilizado é o de laminação contínua, que elimina a etapa de laminação a quente. O alumínio é solidificado entre dois cilindros refrigerados internamente por água, que giram em torno de seus eixos, produzindo uma chapa com seção retangular e espessura aproximada de $6 \mathrm{~mm}$. Posteriormente, esta chapa é enrolada, obtendo-se assim um produto similar àquele obtido por laminação a quente. Porém, este produto apresentará uma estrutura bruta de fusão bastante refinada, dada a alta eficiência do refinador de grão utilizado no vazamento.

Os laminados se agrupam em três categorias, dependendo de sua espessura: chapa grossa (maior que 6,35 mm), chapa (entre 0,15 e 6,35 mm) e folha (menor que 0,15 mm), e são produzidos em chapas planas ou bobinados, folhas e discos.

Esses semimanufaturados têm diversas aplicações em setores como transportes (carrocerias para ônibus, equipamentos rodoviários, elementos estruturais etc.), construção civil (telhas, fachadas, calhas, rufos, luminárias, refletores etc.), embalagens (latas, descartáveis e flexíveis) e bens de consumo (panelas, utensílios domésticos etc.).

Figura 76 - Processo esquemático de laminação contínua.

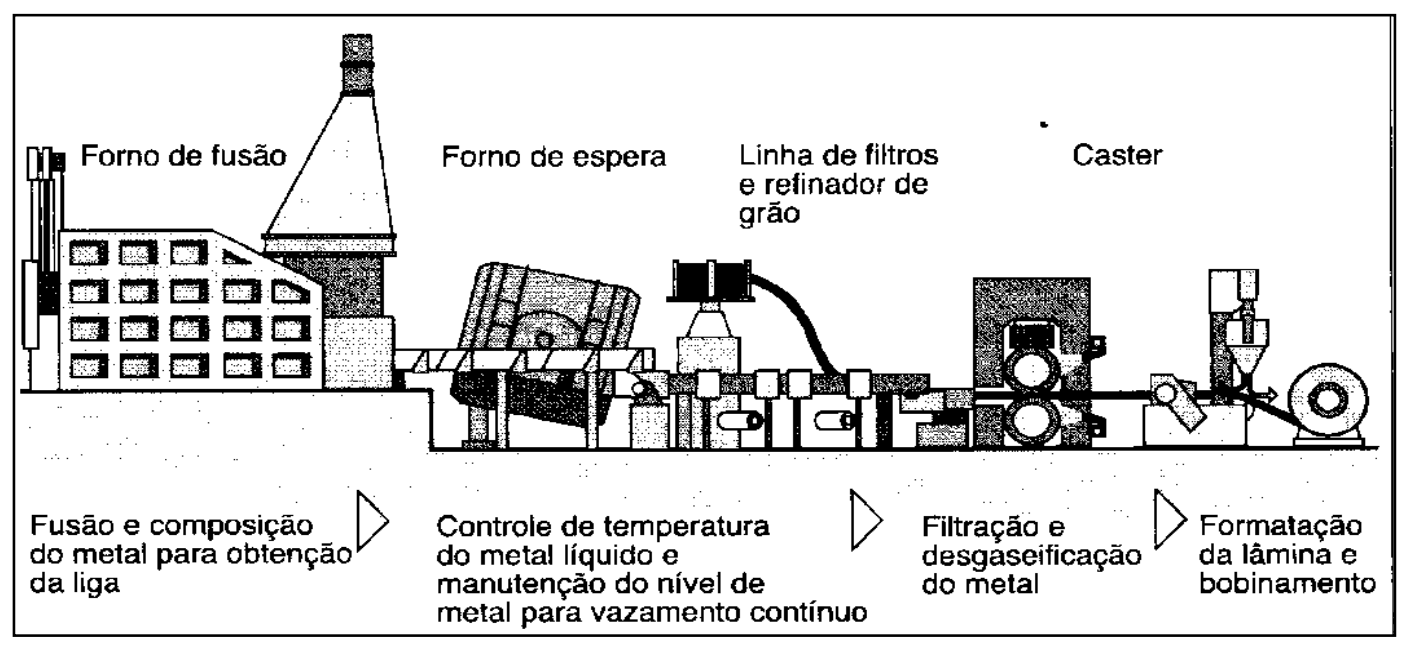

Fonte: ABAL, 2010. 


\subsection{Tratamento de superfície no alumínio}

As características do alumínio permitem que ele tenha uma elevada gama de aplicações. Para cada uma delas, desde os parafusos usados na construção civil às complexas naves espaciais, o tratamento de superfícies é que permitirá um maior desempenho e durabilidade, protegendo-o principalmente contra agressões ambientais e ampliando as opções de uso.

A imagem do alumínio é definida e fixada pelo acabamento aplicado sobre sua superfície. Essa afirmativa constata a importância dos processos empregados para essa finalidade, que determinam as características protetivas e/ou decorativas de alta durabilidade.

Os processos mais utilizados são conversão química, anodização e pintura, sendo os processos de conversão química os mais adotados com finalidades protetivas ou como pré-tratamento para aplicação de processo de acabamento final.

\subsubsection{Anodização}

A anodização é um método muito aceito e bem definido para produzir uma película decorativa e de proteção ao metal de alta qualidade, principalmente nas ligas de alumínio. O uso da anodização abrange um amplo espectro de aplicações, algumas das quais bem específicas, tais como anodização técnica (Dura) para peças que estão sujeitas ao desgaste por abrasão e como camada protetora para refletores e capacitores eletrolíticos; a anodização brilhante para frisos; anodização em cores para ornamentos e utensílios domésticos; e anodização para fins arquitetônicos (janelas, portas, fachadas, gradis, boxes de banheiro etc.) e na construção civil.

A anodização é um processo cujos parâmetros químicos e eletroquímicos podem ser mantidos sob controle. Entretanto, quando esse controle é feito de modo inadequado, ocorrem defeitos no acabamento da superfície que são prejudiciais à sua aparência, resultando em um mau desempenho da camada anódica final.

Para a obtenção desse efeito decorativo e de proteção devem ser tomados alguns cuidados quanto ao acabamento de superfície das peças, à 
estrutura metalúrgica das ligas utilizadas, ao pré-tratamento, à anodização, propriamente dita, e à selagem da camada anódica.

Essa camada, por ser uma oxidação eletrolítica do próprio metal, irá salientar os defeitos existentes ou mesmo revelar irregularidades que não são visíveis no metal bruto. Alguns processos de pré-tratamento disponíveis podem esconder ou eliminar a maioria das irregularidades superficiais, mas, em condições metalúrgicas da liga, não podem ser controladas pela anodização e dependem do processo utilizado na fundição do metal, do controle de processos de extrusão e de laminação durante a sua fabricação.

O alumínio é um metal que aparenta ser inerte à ação atmosférica, devido a uma fina camada de óxido que se forma naturalmente sobre sua superfície. Todavia, é um metal bastante reativo e que reage com ácidos e álcalis com evolução de hidrogênio.

A diluição de alumínio em uma solução de ácido sulfúrico aquecida irá formar o sal sulfato de alumínio e com liberação de hidrogênio. Da mesma forma, o alumínio adicionado a uma solução de ácido fosfórico também causa reação.

Em solução de ácido nítrico ou ácido crômico o alumínio não se dissolve, ocorrendo uma passivação ${ }^{73}$ pela formação de um filme de óxido. A imersão do alumínio em uma solução de ácido fluorídrico irá produzir um filme insolúvel de fluoreto de alumínio (solúvel no excesso de ácido fluorídrico).

A maioria dos metais não ferrosos, como níquel, cobre, zinco etc., apresenta reações similares à do alumínio, com uma exceção importante, pois são dissolvidos em solução de ácido nítrico. Metais como cobre, níquel e ferro são dissolvidos por álcalis, como hidróxido de sódio ou carbonato de sódio. Quando metais como zinco, bismuto estanho ou alumínio, por exemplo, são colocados em solução de soda cáustica (hidróxido de sódio) a quente, se dissolvem formando um sal e desprendendo hidrogênio.

\footnotetext{
${ }^{73}$ Passivação - Processo para aplicação em superfícies metálicas. A invenção refere-se a um método para a passivação de superfícies metálicas pelo tratamento da superfície com o uso de uma composição aquosa ácida, contendo pelo menos um grupo ácido solúvel em água compreendendo polímero e íons de $\mathrm{Zn}, \mathrm{Ca}, \mathrm{Mg}$ ou $\mathrm{Al}$; o citado método sendo particularmente contínuo para a passivação de metais em tira.
} 
No caso do alumínio é formado um sal conhecido como aluminato de sódio. Esse sal resultante se ioniza, produzindo íons de sódio, com cargas positivas, e íons de alumínio, com cargas negativas.

Metais que possuem a capacidade de produzir sais, os quais podem estar presentes como íon ${ }^{74}$ metálico em ânions ${ }^{75}$ ou cátions ${ }^{76}$, são conhecidos como metais anfóteros ${ }^{77}$.

Reações similares ocorrem com outras soluções contendo sais de sódio, porém de uma forma bem mais lenta. A característica anfótera do alumínio permite que ele seja desengraxado ou fosqueado em uma solução alcalina de baixo custo.

Quando filmes de óxidos são muitos resistentes, poderá ser necessária à utilização de limpeza acida. Para essa limpeza é possível o uso do acido sulfúrico, que é um produto de baixo custo, mas que, todavia, não possui um grande poder de ataque no alumínio. Como alternativa para o funcionamento perfeito desta solução, é possível a adição de um agente molhante e a utilização do processo a quente $\left(60^{\circ} \mathrm{C}\right)$.

Sem a presença de um fino filme de óxido em sua superfície, o alumínio será um metal extremamente reativo. Esse filme não é homogêneo e poderá ser constituído de forma a comprometer o tratamento de superfície. Isto se explica pelo fato que os óxidos de elementos de liga, particularmente o magnésio, podem produzir manchas esbranquiçadas no desengraxe e fosqueamento alcalino; óxidos de pequenas partículas intermediárias, principalmente alumínio-ferro-silício, podem comprometer o fosqueamento alcalino, e as graxas e lubrificantes de operações anteriores podem se fixar entre a superfície do alumínio e o filme de óxido e não são removidos com facilidade pela limpeza alcalina.

\footnotetext{
${ }^{74}$ Íon - Partícula com carga elétrica, resultante de um átomo ou de um grupo de átomos por perda ou ganho de elétrons.

${ }^{75}$ Ânion - íon de carga negativa.

${ }^{76}$ Cátion - íon com carga positiva.

${ }^{77}$ Anfóteros - Substância que pode se comportar como um ácido ou como uma base, dependendo de outro reagente presente. Se estiver na presença de ácido, comporta-se como uma base; se estiver na presença de uma base, comporta-se como um ácido.
} 


\subsubsection{Processo da anodização}

É um processo eletrolítico que promove a formação de camada controlada e uniforme de óxido na superfície do alumínio. A Figura 77, a seguir, mostra o processo eletrolítico ou eletroquímico.

Figura 77 - Processo eletrolítico ou eletroquímico

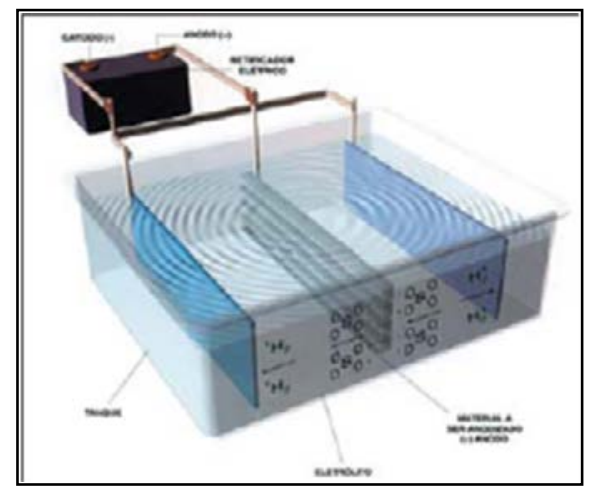

Fonte: MENEGHESSO, 2009.

A estrutura da camada anódica $^{78}$ é constituída por células hexagonais, exemplificada na Figura 78, sendo cada uma delas com um poro central. No fundo dos poros forma-se uma fina camada barreira, que separa o óxido em formação do alumínio.

Essencialmente, o tamanho das células é determinado pela voltagem, enquanto a espessura da camada é determinada pelo número de Coulomb ${ }^{79}$ que passa através dela (relação corrente $x$ tempo).

As características da camada anódica dependem do tamanho e do volume dos poros e estão diretamente ligadas à remoção do calor gerado no processo.

\footnotetext{
${ }^{78}$ Camada anódica - Camada de óxido que se forma sobre a superfície do alumínio.

${ }^{79}$ Coulomb - (símbolo: C) É a unidade de carga elétrica pelo Sistema Internacional (SI). É uma unidade composta, definida a partir do ampére: 1 coulomb é a quantidade de carga elétrica carregada pela corrente de 1 ampére durante 1 segundo.
} 
Figura 78 - Corte esquemático de um feixe de células hexagonais

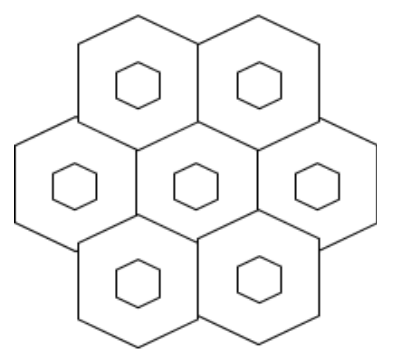

Fonte: ABAL, 2006.

Ao oxidar uma peça de alumínio em uma solução que tenha uma ação dissolvente sobre a camada de alumina, a densidade da corrente, para uma determinada tensão, diminui muito rapidamente. Utilizando-se um exemplo, em uma solução de ácido sulfúrico a $180 \mathrm{~g} / \mathrm{l}$ e temperatura de $20^{\circ} \mathrm{C}$, a densidade de corrente será de 1,5 A/dm2 para uma tensão aplicada de $14 \mathrm{~V}$. Tem-se, então, a formação de uma camada de alumina contínua e compacta, que impede a passagem da corrente elétrica, chamada de "camada barreira". A espessura dessa película representa a distância que um íon metálico pode alcançar através de seu próprio óxido, sob a influência de um dado potencial.

Depois dos primeiros segundos de eletrólise é formada uma verdadeira camada barreira, cuja espessura tende a assumir um valor limite de 14 Ângstrons ${ }^{80} / \mathrm{V}$.

A camada de óxido formada é constituída de células hexagonais sobrepostas, onde o centro será de alumina amorfa, pouco resistente a ácidos, e a periferia será formada de alumina cristalina, muito resistente a ácidos. Aparecem, então, na superfície da camada barreira milhares de pontos de ataque, que são consequência do efeito da dissolução da película pelo eletrólito, que se produz no centro das células de alumina, e que constitui o começo dos poros. Forma-se, assim, a camada porosa. Cada ponto de ataque (poro) pode ser considerado como uma fonte de corrente, a

80 Ângstron - Unidade usada para medidas de comprimentos de onda de radiação eletromagnética. Um angstrom equivale a um centésimo milionésimo de um centímetro, ou seja, 0,00000001 centímetros. Este número tão pequeno também pode ser escrito como $1 \mathrm{x}$ $10^{-8}$ centímetros, se usarmos a chamada notação científica. O ângstrom é, realmente, uma unidade de medida bastante especial. Basta notarmos que uma folha de papel tem a espessura de, aproximadamente, 1.000 .000 de ângstrons. Temos também que 10.000 ângstroms correspondem a 1 mícron. Seu símbolo: $\AA$. 
partir da qual vai se desenvolver um campo de potencial, os íons, que se apresentam na separação óxido-eletrólito e fornecem o oxigênio que transforma em óxido a porção reatacada.

Simultaneamente, a ação de dissolução do eletrólito continua se manifestando na base dos poros, tendendo a diminuir a espessura da camada barreira que se desenvolve. Os poros se alongam, fazendo com que os íons penetrem facilmente. Ocorre liberação de calor, o que tende a favorecer a dissolução.

A camada anódica de uma superfície, a partir de um poro isolado, está representada nas Figuras 79 e 80.

Figura 79 - Película anódica no princípio de formação em um eletrólito, com ação dissolvente sobre a película.
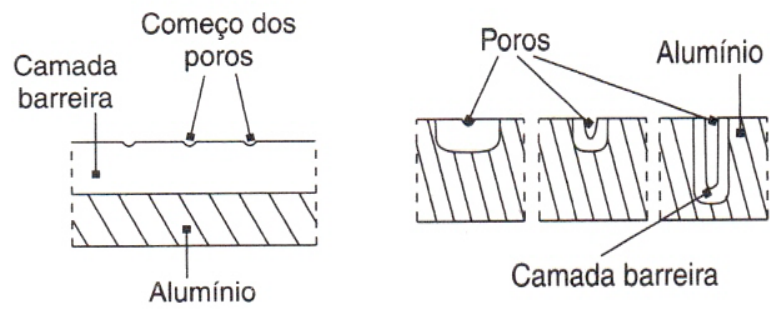

Fonte: ABAL, 2011.

Figura 80 - Camada anódica.

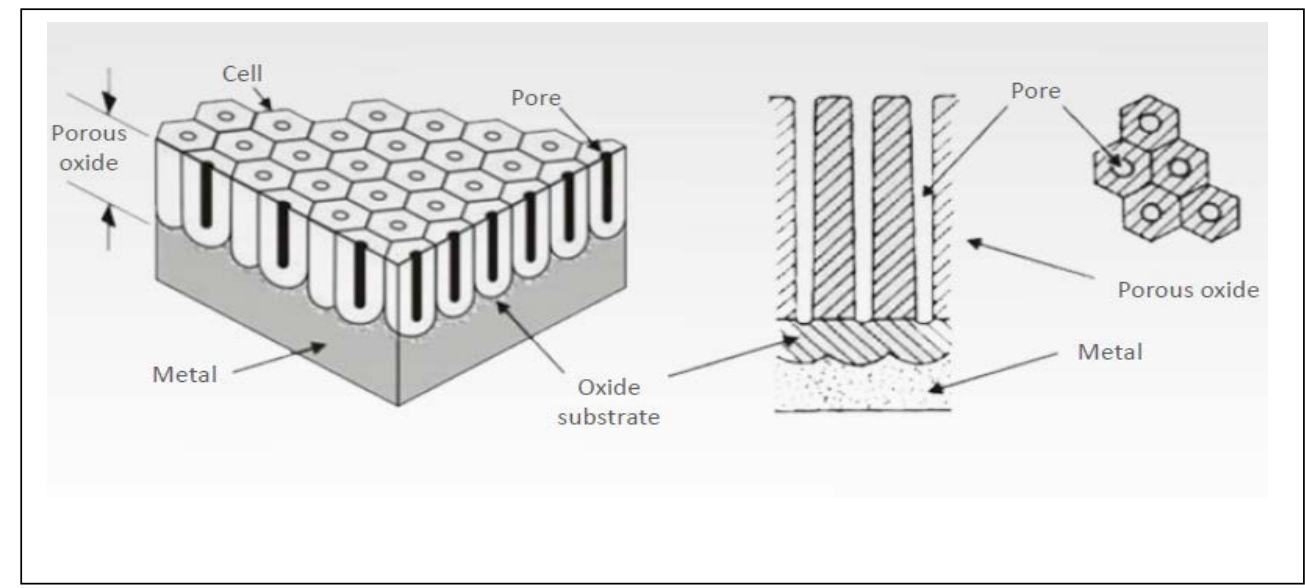

Fonte: ALMECO, 2008.

Anodização em meio sulfúrico é o processo anódico mais utilizado universalmente, constituindo-se de ácido sulfúrico, de custo relativamente 
baixo. Em função da temperatura e da voltagem, apresenta uma versatilidade quanto à qualidade da camada formada, que vai desde a porosa, de fácil coloração (bens de consumo/arquitetura) até aquelas extremamente duras (fins técnicos).

Parâmetros que influenciam a anodização nas camadas são:

- Concentração do ácido sulfúrico no eletrólito;

- Temperatura do eletrólito;

- Voltagem utilizada;

- Densidade de corrente aplicada;

- Agitação.

Um dos fatores mais importantes e não mencionado é o custo de energia. A tarifa de energia é baseada no quilowatt/hora, comumente combinada com a máxima demanda da carga.

As impurezas mais importantes presentes no eletrólito, que causam efeitos indesejáveis à superfície do alumínio, são descritas na Tabela 29 a seguir.

Tabela 29: Impurezas e seus efeitos

\begin{tabular}{|l|l|}
\hline Impurezas & \multicolumn{1}{|c|}{ Efeito } \\
\hline $\begin{array}{l}\text { Alumínio } \\
\text { dissolvido }\end{array}$ & $\begin{array}{l}\text { É uma impureza que afeta a densidade da corrente, sendo gerada com } \\
\text { qualquer voltagem. Pode ocasionar problemas na coloração e precipitar } \\
\text { nos banhos, se não for controlada. A razão da sua formação é devido ao } \\
\text { fato de que um dos três átomos de alumínio permanece na solução e não } \\
\text { forma óxido. Várias empresas controlam o teor máximo de alumínio em } 15 \\
\text { g/l. }\end{array}$ \\
\hline Ferro & $\begin{array}{l}\text { É uma impureza indesejável e pode ser encontrada no ácido sulfúrico } \\
\text { comercial. Problemas podem surgir, como perda de brilho na anodização } \\
\text { e amolecimento do filme, quando sua concentração no eletrólito exceder } \\
22-50 \text { ppm. }\end{array}$ \\
\hline
\end{tabular}




\begin{tabular}{|l|l|}
\hline $\begin{array}{l}\text { Cobre/ } \\
\text { Níquel/ } \\
\text { Manganês }\end{array}$ & $\begin{array}{l}\text { Reduzem a resistência intrínseca à corrosão da camada anódica, se } \\
\text { exceder a } 50 \mathrm{ppm} \text {, quando submetidos a testes de salt spray }{ }^{81} \text {. Esses } \\
\text { metais também reduzem o brilho da anodização. }\end{array}$ \\
\hline $\begin{array}{l}\text { Cloro/ } \\
\text { Flúor }\end{array}$ & $\begin{array}{l}\text { Mesmo em baixos níveis podem produzir pitting na camada - manter } \\
\text { abaixo de } 25 \mathrm{ppm} .\end{array}$ \\
\hline $\begin{array}{l}\text { Nitratos- } \\
\mathrm{NO}_{3}\end{array}$ & Não deve exceder a $30 \mathrm{ppm}$, para melhorar o brilho. \\
\hline $\begin{array}{l}\mathrm{Fosfatos}- \\
\mathrm{PO}_{4}\end{array}$ & $\begin{array}{l}\text { Pode se acumular devido à lavagem deficiente após a anodização. } \\
\text { Transferência de fosfato do abrilhantamento para a selagem ocasionará } \\
\text { deficiência nos testes de selagem. }\end{array}$ \\
\hline
\end{tabular}

Fonte: ABAL, 2010.

A voltagem requerida para produzir uma determinada densidade de corrente depende da liga conforme tabela, e também das condições particulares da anodização que são escolhidas.

Materiais brilhantes requerem técnicas adequadas de anodização. Há uma perda de brilho na anodização, devido aos constituintes intermetálicos do material que estão sendo incorporados ao filme durante o processo.

Entretanto, essa perda é mais acentuada quando a densidade da corrente de anodização aumenta. Nas mesmas densidades de corrente, o uso de eletrólitos mais fracos requer voltagens maiores para a mesma densidade de corrente. Isto resultará numa perda maior de brilho durante a anodização.

A mistura de materiais de ligas diferentes é um problema para o anodizador, que pode desconhecer esta mistura e alterar o comportamento do processo:

- Ligas contendo magnésio requerem maiores densidades decorrentes do que o alumínio puro. Para elevados teores de magnésio o efeito será maior.

\footnotetext{
${ }^{81}$ Salt spray - Pt. "ensaio névoa salina". Ensaio comparativo muito importante na área de corrosão. Para execução do teste é necessária uma câmara que simula um ambiente marinho severo, com concentração de sal e temperatura controlada. Tal câmara denominase Câmara de Névoa Salina (CNS), e é padronizada por norma nacional (ABNT - NBR 8094) e internacional (ASTM B117 e DIN 50.021).
} 
- Ligas com alto teor de cobre/alta dureza requerem maiores voltagens que o alumínio puro, mas menores temperaturas do eletrólito, devido à dissolução dos constituintes ricos em cobre na anodização.

- As ligas de fundição contendo $5 \%$ de silício ou mais exigem voltagens de 20 a 30 Volts, para que seja mantida constante a densidade de corrente.

- Os produtos fundidos nunca devem ser anodizados, como chapas e perfis, por exemplo, não sendo recomendado o processamento em meio sulfúrico, mas sim em meio crômico.

- Baixas densidades de corrente podem minimizar as diferenças na espessura do filme obtida com cargas mistas, mas o tempo de anodização deve ser estendido convenientemente.

As gancheiras nunca devem ser de ligas, mais facilmente anodizáveis do que as peças, visto que roubam corrente do processo.

As selagens de camadas anódicas foram originalmente obtidas de forma empírica. Qualquer pessoa que tenha manuseado uma camada anódica não selada sabe que ela tem uma superfície altamente absorvente.

Antigamente, as peças sofriam simplesmente uma lavagem a quente, para secagem fora da linha de produção. Descobriu-se, então, que as peças continham marcas de dedos, manchas de tintas, etc. Assim, foi feita uma investigação mais sistemática das variáveis da selagem, tornando-se evidente que os parâmetros de temperatura, tempo e $\mathrm{PH}^{82}$ eram significativos.

A estrutura e composição das camadas anódicas produzidas em meio de ácido sulfúrico não são simples de se determinar, mas o consenso estabelece o seguinte:

- A camada consiste principalmente de óxido de alumínio.

- Os íons sulfato do eletrólito ficam incorporados na camada, com cerca de $15 \%$ em peso.

- Há um excesso de íons de alumínio, aqueles necessários para formar Al2O3 em parte da fronteira da camada barreira, e uma falta nas camadas superiores.

- A concentração de íons sulfatos diminui na superfície externa

${ }^{82} \mathrm{PH}=\left(\mathrm{H}_{3} \mathrm{O}^{+}\right)$. A Escala de $\mathrm{pH}$ constitui um instrumento básico da classificação das substâncias em substâncias ácidas, substâncias neutras ou substâncias básicas ou alcalinas. 
do óxido para a camada - barreira.

A reação básica da selagem parece ser de conversão do óxido de alumínio amorfo em uma forma estável e hidratada conhecida como boemita ${ }^{83}$ :

$$
\mathrm{Al} 2 \mathrm{O} 3+\mathrm{H} 2 \mathrm{O} \rightarrow 2 \mathrm{AlOOH} \text { (Óxido de alumínio }+ \text { Água } \rightarrow \text { Boemita) }
$$

Uma camada anódica consiste de uma célula hexagonal com um poro central, que está separado do metal por uma camada - barreira muito fina. A conversão do óxido de alumínio para a boemita envolve um acréscimo de volume, tanto quanto um significativo aumento na resistência elétrica e na resistência da constante dielétrica da camada de anodização.

Os poros de uma camada anódica de ácido sulfúrico são de aproximadamente $150-200 \AA$ de diâmetro. O processo envolve a difusão de íons hidroxilas através da camada anódica e, sendo um processo de difusão, a taxa de selagem não é linear, relacionando- se diretamente com o tempo de selagem. Isto acarreta as seguintes implicações práticas:

- A taxa de selagem, isto é, conversão do óxido para a boemita, diminui progressivamente com o tempo de selagem.

- Em função do diâmetro dos poros e do processo de difusão, a camada de óxidos mais próxima à superfície será convertida em boemita mais rapidamente do que a da base dos poros.

O efeito dos parâmetros acima na selagem tem sido investigado com a utilização de água deionizada, para determinar o aumento de peso em camada de 25 micrometros, em temperaturas de $80^{\circ} \mathrm{C}, 100^{\circ} \mathrm{C}$ e vapor a $115^{\circ} \mathrm{C}$. A maior parte da selagem ocorre nos primeiros 5 a 10 minutos, e então progride muito vagarosamente.

Testes demonstraram que a melhor selagem é obtida com $\mathrm{PH}$ 5,5- 6,5 e que a qualidade de selagem está relacionada com a temperatura, de forma que uma boa selagem requer uma temperatura próxima a do ponto de ebulição. O tempo de selagem depende da espessura da camada e dos

${ }^{83}$ Boemita (Al2O3.H2O). - Do grupo dos bauxitos, é um material heterogêneo composto principalmente de minerais de hidróxido de alumínio, gibsita (Al2O3.3H2O) e diásproro (Al2O3. $\mathrm{H} 2 \mathrm{O})$. 
requisitos da especificação do teste de selagem, sendo a correta dimensão de 2,5-3,0 $\mathrm{min} / \mathrm{micrometros}$.

A característica essencial do processo é que ele opera à temperatura de $25-30^{\circ} \mathrm{C}$, e que a solução de selagem contenha $1-2 \mathrm{~g} / \mathrm{l}$ de íons níquel e 0,5-0,8 g/l de íons fluoreto. Se a temperatura aumentar significativamente acima da faixa estabelecida, não mais proporcionará uma selagem efetiva, enquanto temperaturas mais baixas resultarão numa selagem mais vagarosa e de qualidade insatisfatória.

\subsubsection{Etapas básicas do processo de anodização}

O processo de anodização é composto por uma série de etapas básicas, comuns a todos os tipos de anodização. Cada processo adquire uma característica própria que demonstra o tipo de acabamento e são identificados por estágios que consideram cada tipo de anodização, conforme Figura 81 que explicita os fins:

$\rightarrow \quad$ Anodização para fins arquitetônicos

$\rightarrow$ Anodização para fins técnicos (DURA)

$\rightarrow$ Anodização para bens de consumo 
Figura 81 -Fluxograma de identificação dos estágios de anodização, conforme aplicação.

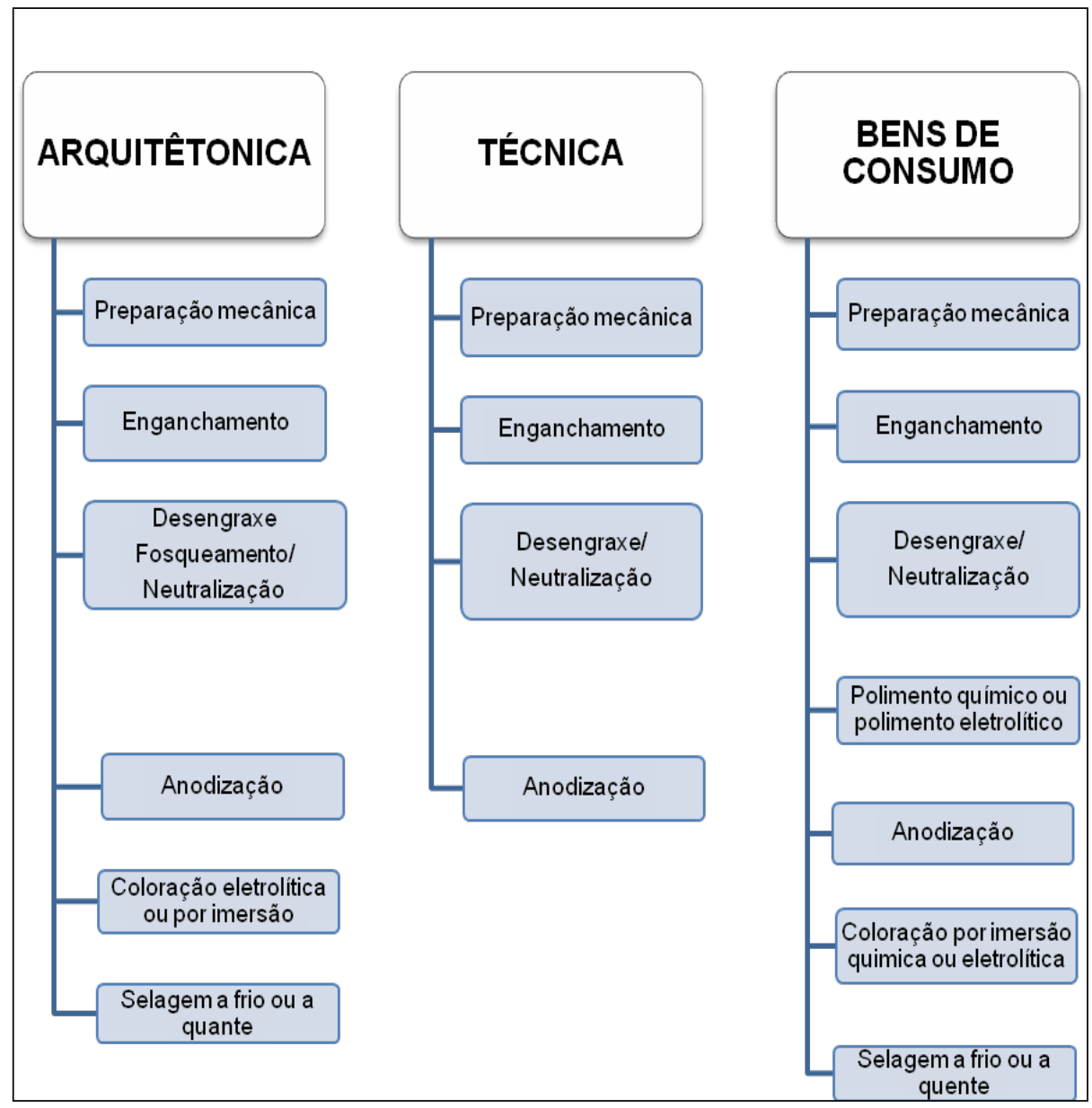

Fonte: ABAL, 2011.

Antes de sofrer o tratamento de superfície, o alumínio e suas ligas podem ser submetidos a diversos tratamentos mecânicos e químicos, com a finalidade de melhorar seu aspecto superficial pela eliminação de eventuais defeitos e/ou criação de novos efeitos decorativos. 
Figura 82- Fluxograma dos estágios básicos no processo de anodização

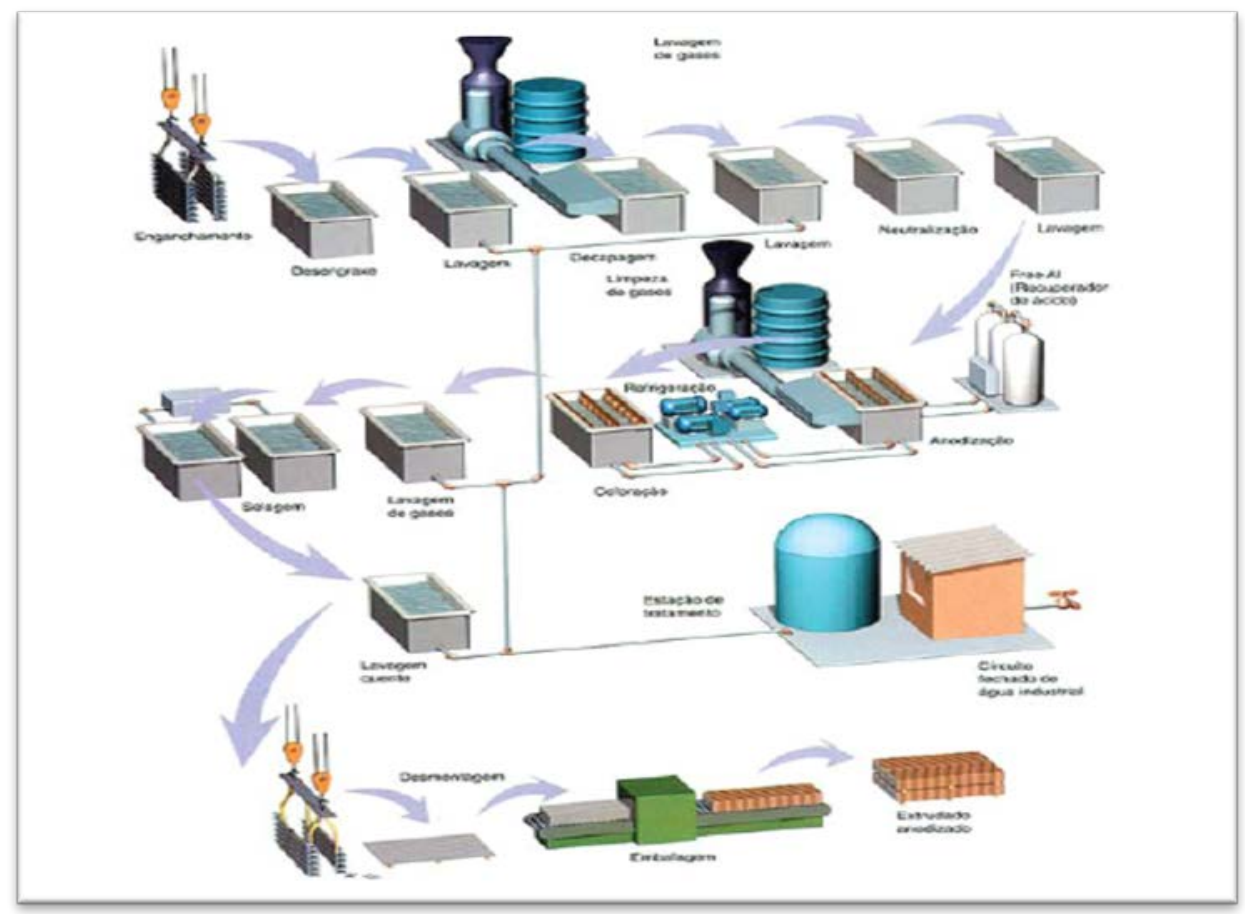

Fonte: - MENEGHESSO, 2007.

Tratamentos mecânicos - O jateamento produz uma textura fosca acetinada sobre a superfície do alumínio, e utilizam partículas abrasivas lançadas com grande energia cinética, eliminando praticamente todos os tipos de imperfeições nos produtos extrudados, como faixas, marcas de manuseio, atritos etc.

O jateamento com um fino abrasivo de areia produz um acabamento fosco de granulação fina nos produtos trabalhados ou fundidos de alumínio. Este tipo de jateamento é altamente suscetível a riscos e a manchas de impressos digitais. Por essa razão, as superfícies dos acabamentos foscos, usualmente, são protegidas por um revestimento anódico ou verniz transparente.

A anodização é o tratamento protetivo mais popular porque conserva a aparência original da superfície. Quando uma superfície jateada é anodizada, resulta em uma coloração levemente acinzentada, devido às partículas abrasivas que contêm sílica (vidro ou areia) incrustada na superfície do alumínio. 
Nem todas as ligas de alumínio podem receber jateamento com areia. As que contêm $99 \%$ de alumínio obtêm um acabamento anódico transparente, mas ligas ricas em manganês, silício e cobre ficam coloridas quando anodizadas, e as ligas com alto teor de magnésio correm o risco de segregação e aparecimento de buracos, a menos que sejam usados prétratamentos especiais.

O escovamento mecânico é utilizado para a obtenção de uma textura superficial atraente nos acessórios de alumínio, como, por exemplo, em maçanetas, dobradiças, rosetas, puxadores de gaveta e perfis em geral.

Este acabamento resulta em pequenos riscos paralelos, bem próximos à superfície do metal, que proporcionam um leve brilho de menor refletividade do que as peças polidas. O tratamento protetivo de anodização ou pintura tem de ser imediato, para que seja evitada corrosão ${ }^{84}$.

O lixamento é um acabamento mecânico e tem a capacidade de produzir um efeito visual diferenciado no acabamento final, devido à uniformidade dos sulcos e estrias em função da granulometria do abrasivo (lixa). O uso das lixas é eficiente apenas nas superfícies lisas.

O polimento mecânico é realizado através de correias, conjuntos de discos (rodas) de pano ou flanela; produz na superfície do alumínio um brilho especular, pela aplicação de abrasivos adequados.

Tratamentos químicos - O tratamento fosco acetinado/aveludado é feito através de um processo químico alcalino, que utiliza soda cáustica com aditivos niveladores e inibidores de ataque, utilizados para tornar opaca a superfície do alumínio. Isto confere um acabamento uniforme fosco acetinado e aveludado.

O abrilhantamento químico é um processo baseado em uma mistura dos ácidos fosfórico, sulfúrico, nítrico e aditivos niveladores de ataque, capazes de tornar a superfície do alumínio lisa e brilhante, e utiliza a diferença de potencial entre o metal aço inox, usado para a construção do tanque, e o alumínio, que produz correntes galvânicas. ${ }^{84}$ Corrosão - Desgaste ou modificação química ou estrutural de um material provocado pela
ação química ou eletroquímica espontânea de agentes do meio ambiente. 
O polimento eletroquímico e químico é essencialmente seletivo de dissolução, no quais os picos de uma superfície rugosa são atacados mais rapidamente do que as depressões, nivelando a superfície.

Após o pré-tratamento, que consiste no polimento mecânico, desengraxe com solução alcalina inibidora e lavagem, a peça é imersa num banho de polimento eletrolítico ou químico.

O polimento eletrolítico tem por objetivo deixar a superfície do metal lisa e brilhante, conferindo um poder refletor máximo e um poder difusor mínimo, eliminando-se os picos e irregularidades da superfície. Esta ação seletiva está diretamente ligada à intensidade de corrente corretamente aplicada ao metal a ser abrilhantado, o qual pode ser atacado antes da sua oxidação. Os banhos de polimento eletrolítico, dependendo da formulação em uso, poderão ser aplicados em cobre, liga de cobre, aço inox, níquel ou liga de níquel, mas o seu principal uso é o alumínio, conforme demonstra a Tabela 30.

Tabela 30 - Formulação típica de uma solução de polimento eletrolítico

\begin{tabular}{|l|l|}
\hline Ácido fosfórico & $75 \%$ em peso \\
\hline Ácido crômico & $6,5 \%$ em peso \\
\hline Ácido sulfúrico & $4,7 \%$ em peso \\
\hline Água & Para $100 \%$ \\
\hline Temperatura & $75-85^{\circ} \mathrm{C}$ \\
\hline Densidade de corrente & $5-15 \mathrm{~A} / \mathrm{dm}^{2}$ \\
\hline Tempo & $2-10$ minutos \\
\hline
\end{tabular}

Fonte: ABAL, 2009.

O mecanismo do polimento químico é considerado análogo ao eletrolítico, com oxidação e dissoluções constantes. A corrente contínua do processo eletrolítico é substituída por correntes galvânicas no processo químico, originadas pela diferença de potencial entre aço inox (constituição do tanque) e o alumínio. 
Agentes químicos fortemente oxidantes $\left(\mathrm{HNO}_{3}+\mathrm{H}_{2} \mathrm{SO}_{4}\right)^{85}$, associados às correntes galvânicas, propiciam a formação de películas de óxidos idênticas às do processo eletrolítico, e sua dissolução ocorre simultaneamente através do $\mathrm{H}_{3} \mathrm{PO}_{4}{ }^{86}$.

Os principais banhos de polimento químicos são á base de ácido fosfórico, com adição de ácido sulfúrico e de ácido nítrico como agentes oxidantes. Para acelerar o processo, é necessário adicionar aditivos compostos de sais de metais pesados.

O principal problema do polimento químico é seu alto grau de toxidade, pela formação de gases nitrosos (cor alaranjada). O sistema de exaustão e lavagem é de extrema importância.

O procedimento ideal para redução da formação dos gases tóxicos é o uso do composto pela solução, apresentada na Tabela 31.

Tabela 31 - Composto ideal para redução da formação dos gases tóxicos

\begin{tabular}{|l|l|}
\hline Ácido fosfórico & $87 \%$ \\
\hline Ácido nitrico & $5 \%$ \\
\hline Ácido sulfúrico & $7 \%$ \\
\hline Aditivos & $1 \%$ \\
\hline Temperatura & $90-95^{\circ} \mathrm{C}$ \\
\hline Tempo de imersão & $0,5-2$ minutos \\
\hline
\end{tabular}

Fonte: ABAL, 2009.

Neste caso, o uso de controles do processo, observando a densidade do banho, com a adição constante de água ou banho novo, deve ser controlada a reposição de ácido nítrico, para um bom rendimento. A concentração do alumínio dissolvido deve ser inferior a $35 \mathrm{~g} / \mathrm{l}$.

${ }^{85}\left(\mathrm{HNO}_{3}+\mathrm{H}_{2} \mathrm{SO}_{4}\right)$ - Ácido nítrico + Ácido sulfúrico.

${ }^{86} \mathrm{H}_{3} \mathrm{PO}_{4}$ - Ácido fosfórico ou ácido ortofosfórico. 
Aspectos físico-químicos - A composição, orientação e tamanho dos grãos individuais nas peças têm um efeito direto na uniformidade da dissolução durante o abrilhantamento. Material com granulação fina, cuja superfície esteja livre de quaisquer imperfeições, como segregação, inclusão de óxidos, marcas e manchas, é mais adequado para o abrilhantamento químico e eletrolítico.

Os melhores resultados são obtidos com ligas que têm composição química uniforme e que não precipitam os constituintes com potenciais diferentes da matriz, durante qualquer tratamento térmico ou de aquecimento. As ligas devem ser adequadas às operações de conformação para que não ocasionem defeitos posteriores, como nervuras, casca de laranja etc.

Em geral, a maior refletância total e especular da superfície abrilhantada são obtidos com alumínio puro, tendo uma estrutura granular fina, que tende a diminuir quando o teor do elemento de liga aumenta.

O efeito dos elementos de liga varia muito com os diferentes processos de abrilhantamento. As superfícies abrilhantadas química ou eletroliticamente podem ser protegidas com uma camada orgânica transparente; porém, a maioria das superfícies abrilhantadas por esses métodos são anodizadas para produzir uma camada protetiva de óxido clara e incolor. Para vários usos decorativos, a camada anódica é colorida posteriormente, antes da selagem.

As principais aplicações dos processos de polimento químico e eletrolítico são funcionais e decorativas. Incluem joias, frisos de automóveis, canetas-tinteiro, luminárias, peças ornamentais coloridas (brilhantes ou naturais), frisos para arquitetura, utilidades domésticas e refletores térmicos para componentes de veículos espaciais. Nos processos onde o polimento é usado como operação final de acabamento, o metal é dissolvido mais vagarosamente e o total de metal removido normalmente varia de 3 a 13 micrometros. Tais procedimentos são usados em ligas de alumínio de alto brilho, com ate $2 \%$ de magnésio, e em alumínio de alta pureza.

Comparando o polimento químico e o eletrolítico, o custo do sistema eletrolítico é mais elevado devido à necessidade do uso de retificadores de 
corrente, tanques com maior volume e revestimentos especiais (chumbo). Neste processo, três fatores importantes se destacam:

- Operacional: os banhos eletrolíticos abrangem maior variedade de ligas, conferindo brilho final superior ao dos banhos químicos. Têm maior vida útil em função da compensação do seu equilíbrio (teor de alumínio dissolvido), via corrente elétrica e temperatura.

- Qualidade: os banhos eletrolíticos, devido à menor tensão superficial, possibilitam maior ataque e nivelamento da superfície, eliminando pequenos riscos.

- Meio ambiente: outra grande vantagem dos banhos eletrolíticos é que não necessitam de sistema de lavagem de gases.

\subsubsection{Tipos de anodização por tratamento químico}

- Anodização brilhante - Bens de consumo: é uma anodização resultante da ação combinada de um tratamento mecânico e/ou químico sobre a superfície do alumínio, aumentando a sua refletividade. Esse tipo de acabamento é muito utilizado em frisos, molduras, eletrodoméstico ou elementos decorativos, para realçar a beleza decorativa do alumínio.

- Anodização fosca - Acetinada: é uma anodização resultante da ação controlada de um tratamento mecânico e/ou químico agressivo sobre a superfície do alumínio, diminuindo sua refletividade, tornando a peça de alumínio opaca. Esse tipo de acabamento é muito utilizado em vitrines, painéis, móveis residenciais de alto padrão, pois valorizam a beleza do efeito decorativo e transmitem a ideia de modernidade desse acabamento.

- Anodização para fins arquitetônicos: é uma anodização resultante de um tratamento químico agressivo sobre a superfície do alumínio, onde a aparência e o aspecto visual são valorizados, porém prevalece as características protetoras contra a corrosão e o desgaste. Esse tipo de acabamento é muito utilizado na construção civil, na forma de fachadas, janelas, portas, gradis etc.

- Anodização para fins técnicos (DURA): é realizada sob condições de processos especiais, para produzir uma película espessa e dura de óxido 
de alumínio, que ofereça alta resistência à abrasão e à corrosão. Esse tipo de acabamento é muito utilizado pelas indústrias aeronáutica, automobilística e de autopeças.

- Anodização colorida eletrolítica: é um processo de coloração da camada anódica (anodização), realizada em uma solução eletrolítica de sais metálicos; normalmente se utiliza estanho metálico, depositado no fundo dos poros pelo uso de corrente alternada. Esse tipo de acabamento é muito utilizado em todos os segmentos industriais, como eletrodomésticos, bens de consumo e, principalmente, na construção civil (em janelas, portas, gradis, boxes de banheiro etc.), exemplificado na figura 83.

Figura 83 - Processo de coloração anódica

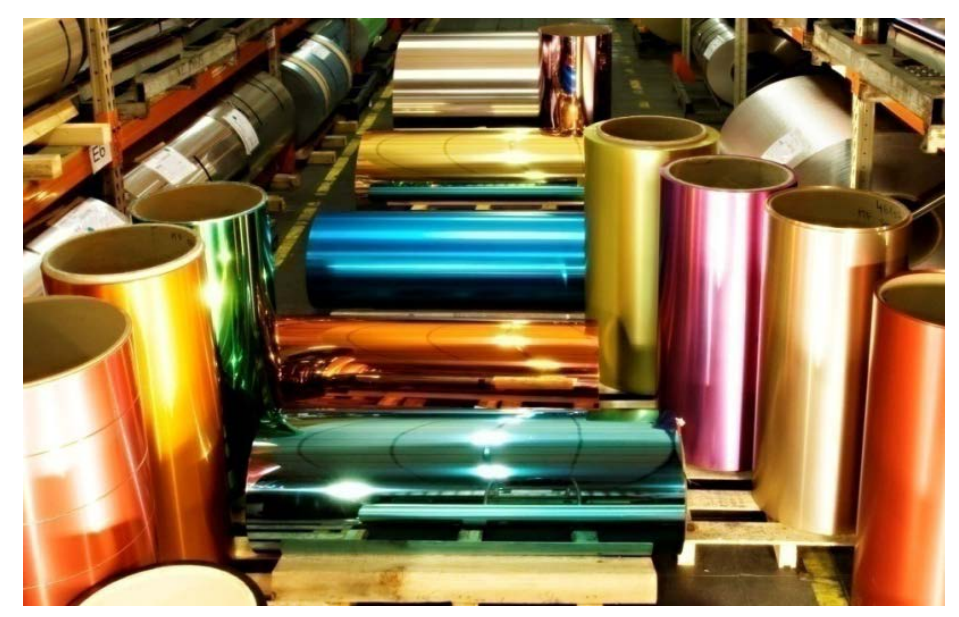

Fonte: ALMECO, 2012 - Linha Bandoxal Decor.

\subsubsection{Anodização em processo contínuo}

Anodização em processo contínuo é um método eletroquímico, cuja aplicação é limitada quase exclusivamente ao alumínio e alguns outros metais que podem se beneficiar deste tipo de tratamento. Ela envolve a transformação das camadas de superfície de uma camada dura, compacta e transparente de óxido de alumínio, por oxidação eletroquímica de uma solução ácida. O processo resulta em um revestimento sem igual no que se refere à aderência ao substrato de metal. 
O acompanhamento cuidadoso dos parâmetros do processo de anodização contínua permite o controle do grão fino do óxido, de modo a maximizar a refletividade da superfície, com uma excelente aparência, distintos acabamentos e com uma redução drástica do fenômeno de iridescência.

As características especiais óticas e estéticas, que caracterizam a gama de produtos, são obtidas com a utilização de uma grande variedade de acabamentos de superfície especial, ou seja, uma grande variedade de produtos na produção de chapas, bobinas ou refletores anodizados, ilustrado na figura 84.

Figura 84 - Acabamento por processo de anodização continua.

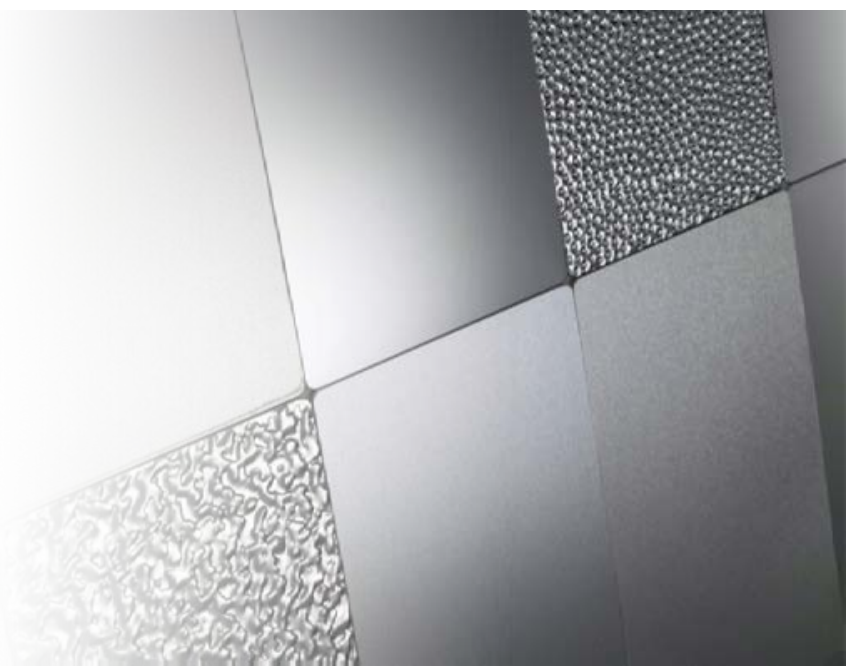

Fonte: ALMECO, 2012.

\subsubsection{Etapas do processo de anodização contínua}

O processo de anodização de forma contínua é realizado em varias etapas, tendo início com a inserção da bobina de alumínio laminado bruto, passando pela torre de resfriamento, desengraxamento, eletropolimento, neutralização, oxidação anódica, coloração eletrolítica, selagem, secagem e rebobinação. A empresa ALMECO S.p.A. ,produz em sua unidade em San Giuliano Milanese (Mi), Itália chapas e bobinas por esse processo, conforme ilustrado na figura 85.

A figura 86 mostra o processo do rebobinador, anodização e desbobinador e na figura 87 vemos o corte de bobinas da linha continua. A 
largura desta linha é de $1250 \mathrm{~mm}$, produzindo chapas de espessuras de 0,2 $\mathrm{mm}-1,5 \mathrm{~mm}$ e com a capacidade máxima de até $7.000 \mathrm{~kg}$.

Figura 85 - Processo de anodização (1 - 11 etapas) .

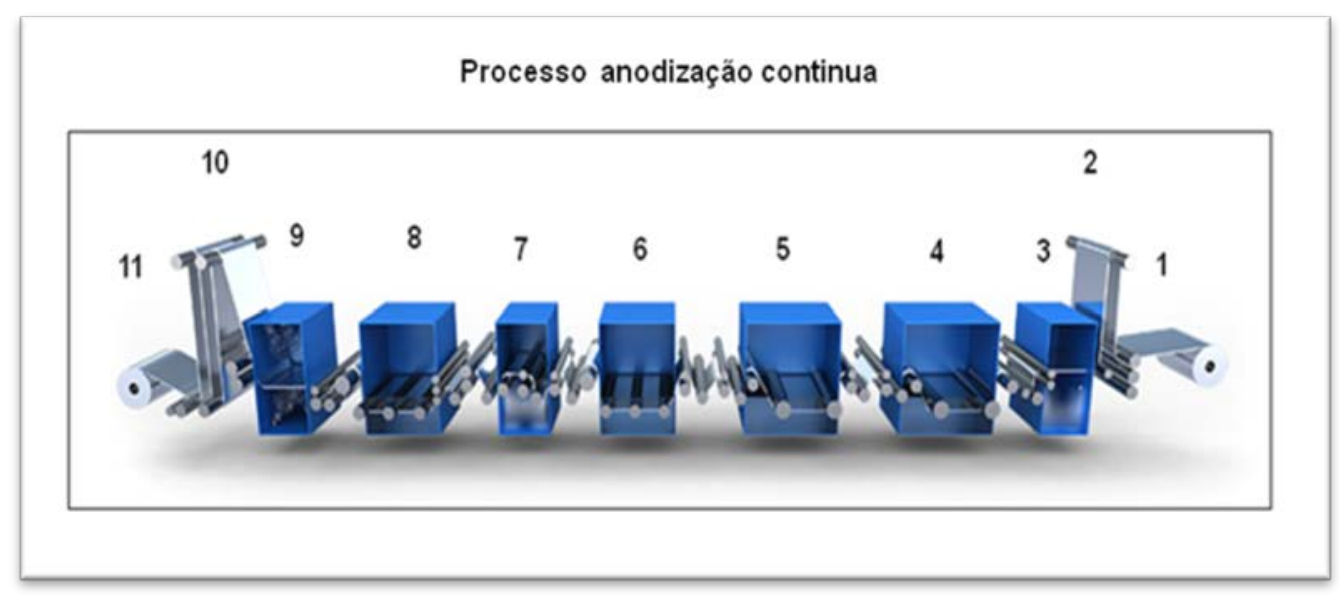

Fonte: ALMECO, 2007.

(1) Desbobinador de lâmina - suporte para bobina de alumínio laminado bruto. Normalmente é equipado com um sistema de freio para controlar a tensão e outro para o alinhamento da lâmina.

(2) Torre de resfriamento - dispositivo de remoção do calor gerado pelo processo de desbobinamento do alumínio.

(3 ) Desengraxamento - processo de remoção química de óleo ou graxa, atráves de solvente orgânico ou detergente alcalino.

(4) Eletropolimento - polimento da superfície metálica, tornando-a anódica em eletrólito apropriado.

(5) Neutralização - processo para remover quaisquer partículas de intermetálicos ou hidróxidos presentes na superficie do alumínio.

(6) Oxidação anódica - processo eletrolitico de oxidação pelo qual a superfície do alumínio é convertida em uma camada de óxido.

(7) Coloração eletrolítica - coloração de camadas de óxidos anódicas pela deposição de óxidos metálicos na estrutura porosa do alumínio.

(8) Selagem - tratamento aplicado após a anodização; aumenta a resistência da camada anódica contra manchas e corrosão.

(9) Secagem - processo de cura; tem como função promover a completa secagem da película anódica. 
(10) Torre de armazenamento - suporte para o rebobinador.

(11) Rebobinador - Estrutura que rebobina o alumínio pré-anodizado.

Figura 86- Etapas do rebobinador, anodização e desbobinador da linha contínua.

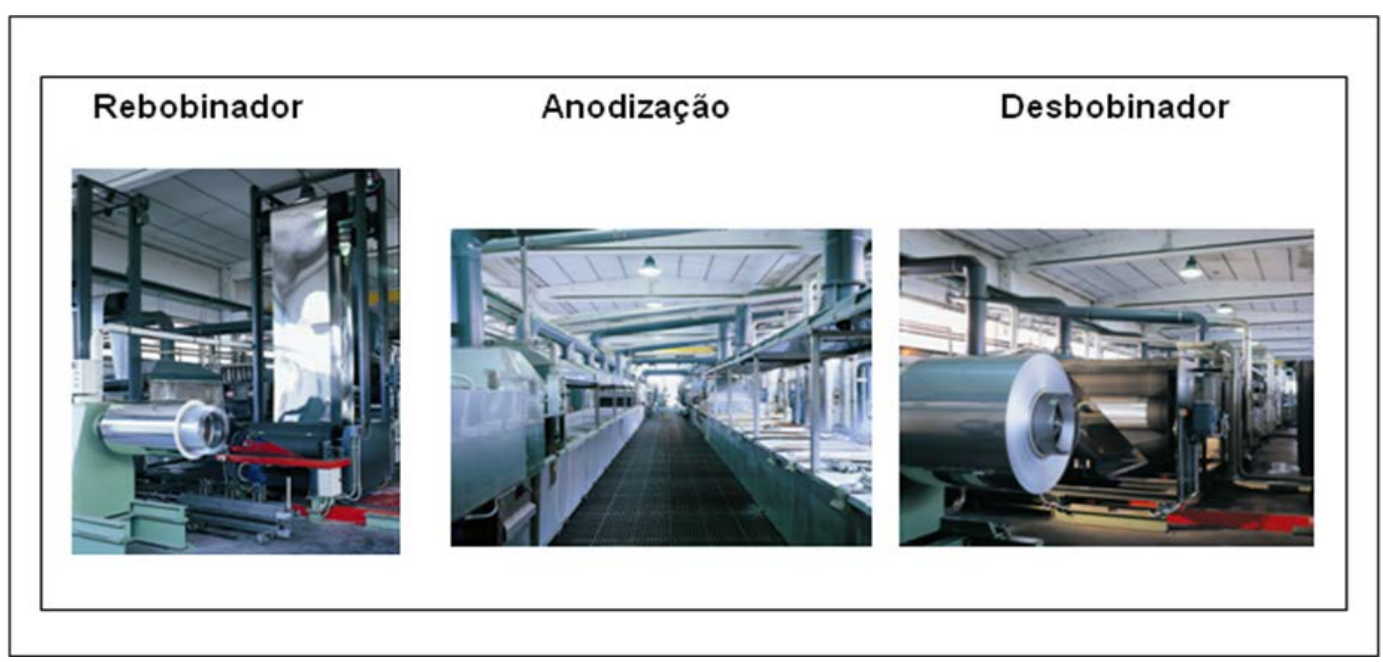

Fonte: ALMECO, 2007.

Figura 87 - Linha de corte de bobinas
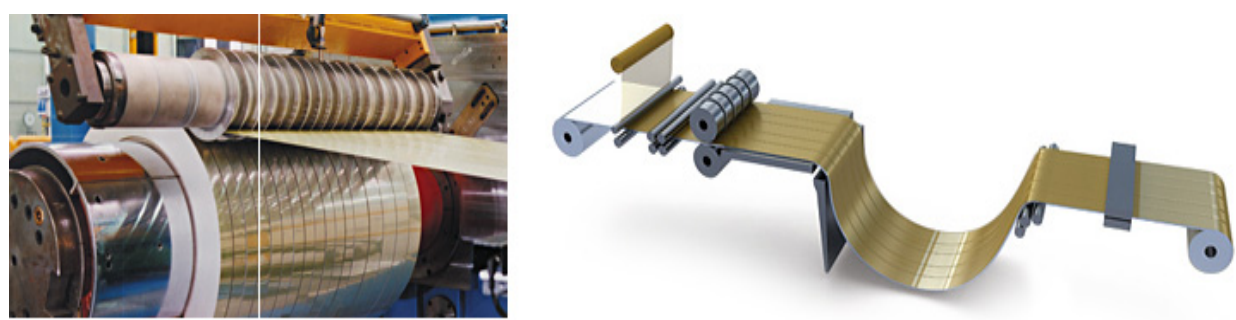

Fonte: ALMECO, 2007. 


\subsubsection{Principais vantagens no processo de pré-anodização}

As principais vantagens do alumínio pré-anodizado, em relação ao alumínio natural, estão relacionadas à redução da rugosidade da superfície (Figura 60), elevando sua qualidade, à refletância (que se apresenta superior e controlada), à amplititude na escolha de acabamentos, a resistência à abrasão e à corrosão.

Figura 88 - Redução da rugosidade da superfície (rugosidade e dissolução de micro-picos formados durante a laminagem) por polarização anódica em um banho de ácido concentrado

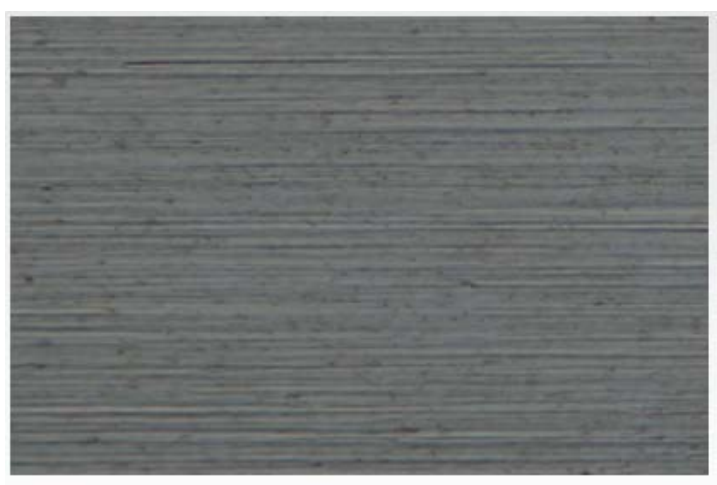

Raw materials (100x)

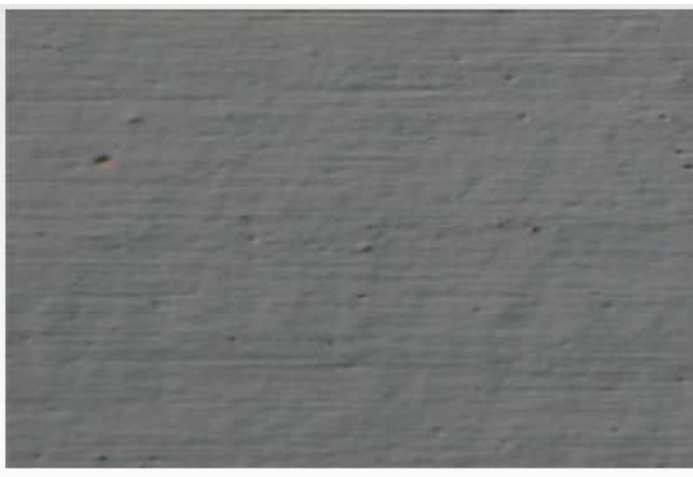

Electro-brightened and anodized material $(100 x)$

Fonte: ALMECO, 2012.

Figura 89 - Bobinas de alumínio natural e bobina de alumínio pré-anodizado
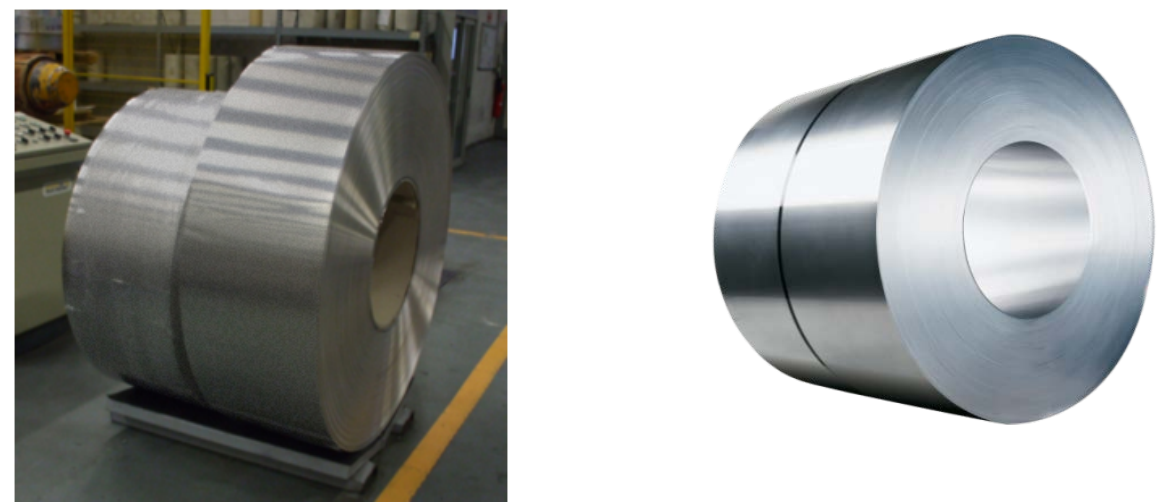

Fonte: ALMECO, 2012.

Dependendo da liga de alumínio utilizada e da camada de deposição do óxido de alumínio, os resultados finais na reflexão total da superfície são distintos, conforme exemplifica a Figura 90. 
Figura 90 - Influência da liga e revestimento na reflectância final do material
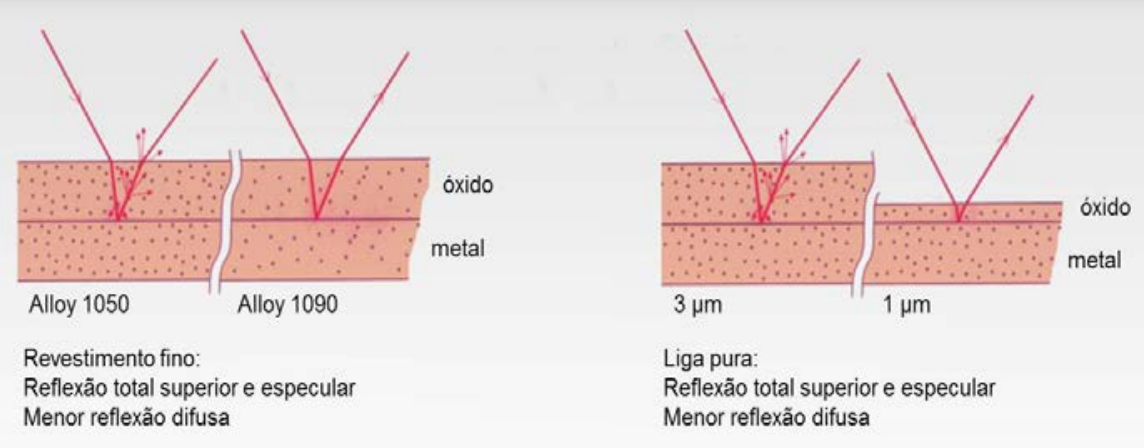

Fonte: ALMECO, 2012.

\subsubsection{Anodização por processo de deposição física do vapor - PVD (Physical Vapour Deposition)}

O processo PVD (Deposição física de vapor) é uma técnica de deposição de filmes finos (metálicos ou cerâmicos) através da vaporização destes materiais em câmaras especiais. De forma geral este processo envolve controle de aquecimento, potencial e pressão. O processamento PVD é feito sob alto vácuo e temperaturas que variam entre $150^{\circ}$ e $500^{\circ} \mathrm{C}$.

O material de revestimento sólido de alta pureza (metais como titânio, cromo e alumínio) é evaporado por calor ou bombardeado com íons (deposição catódica). Ao mesmo tempo, é introduzido um gás reativo (por exemplo, nitrogênio ou um gás que contenha carbono) formando um composto com o vapor metálico que se deposita nas ferramentas ou nos componentes na forma de um revestimento fino e altamente aderente.

O processo PVD vaporiza o material sólido por calor ou sputtering e recondensa o vapor sobre a superfície do substrato para formar o filme fino sólido, exemplificado na figura 63 , onde temos o substrato do alumínio.

Principais etapas do tratamento PVD:

- O material a ser depositado (fonte sólida) é convertido à fase vapor por processo físico.

- O vapor é transportado da fonte até o substrato através de uma região de baixa pressão. 
- O vapor condensa sobre o substrato para formar o filme fino.

- A conversão para a fase gasosa pode ser feita por adição de calor,por evaporação

- Ou pelo desalojamento dos átomos da superfície da fonte através de transferência de momento por bombardeio iônico - sputtering.

Figura 91 - Camadas reflexivas e protetoras do alumínio pelo sistema PVD, desde o substrato do alumínio

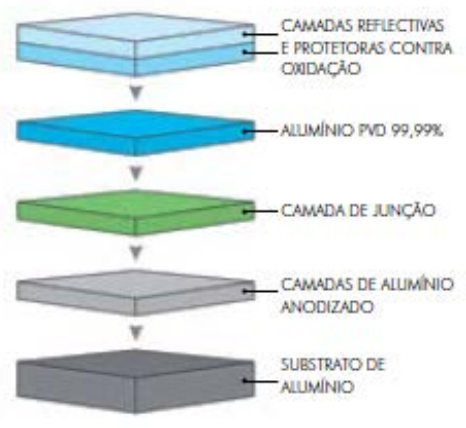

Fonte: ALMECO, 2011.

Figura 92 - Linha de produção PVD (Physical Vapour Deposition). ALMECO $\mathrm{GmbH}$, Bemburg, Alemanha.

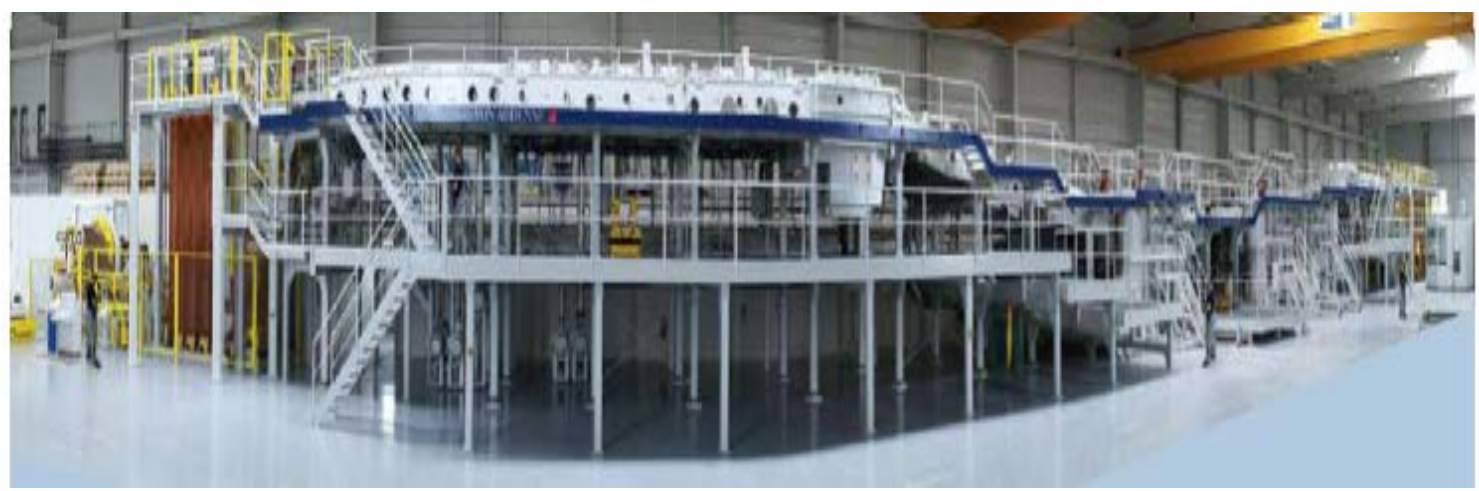

Fonte: ALMECO, 2011. 
Figuras 93 e 94- Vista da cabine de controle, estágio de entrada onde o processo de deposição a vácuo é criado
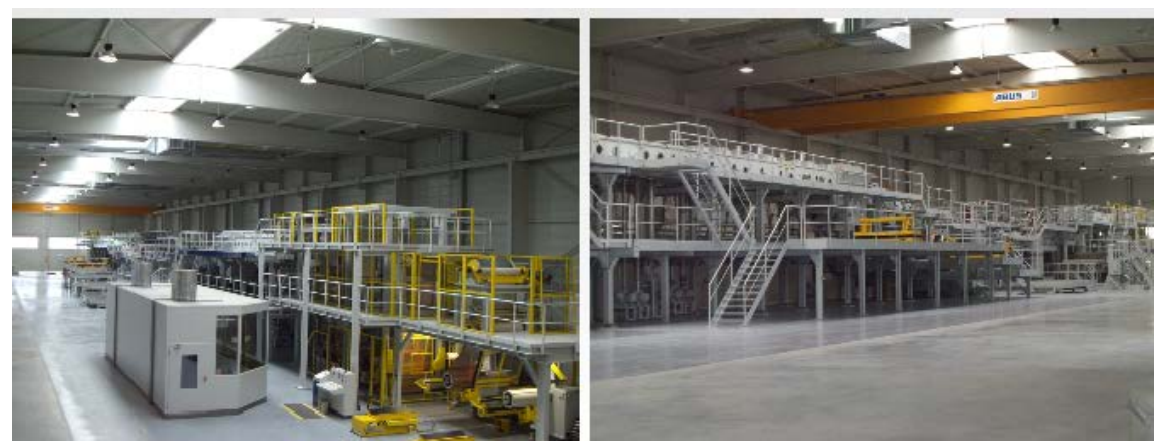

Fonte: ALMECO, 2011.

Figuras 95 e 96 - Processo magnetron sputtering

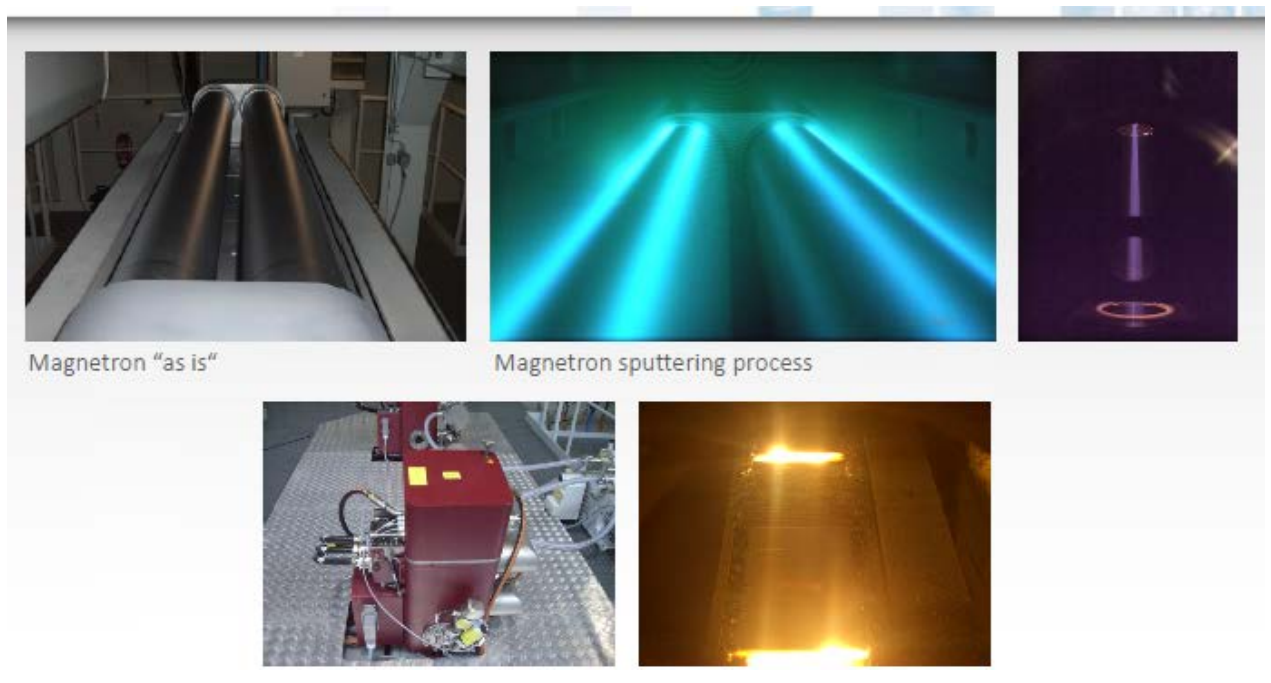

Fonte: ALMECO, 2011.

Figuras 97 e 98- Refletômetro ${ }^{87}$
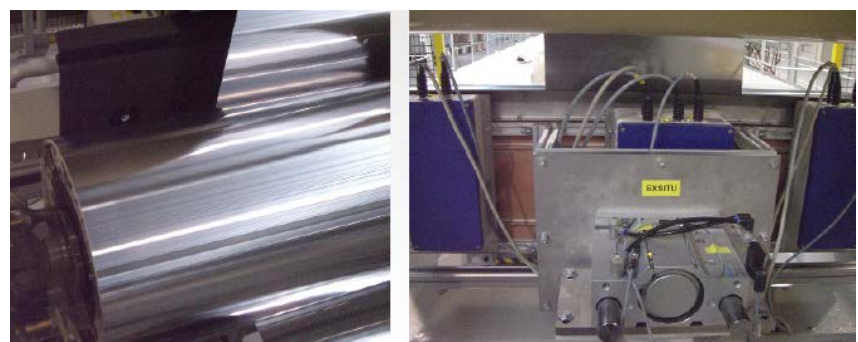

Fonte: ALMECO, 2011.

${ }^{87}$ Refletômetro - Instrumento destinado a medir os fatores de reflexão de superfícies refletivas. 
A grande particularidade desta técnica de tratamento PVD é que ela permite tratar sob vácuo uma grande extensão de metal de forma contínua. Este processo é conhecido como air-to-air.

A tecnologia PVD é utilizada na fabrica da ALMECO na cidade de Bemburg, Alemanha é denominado de linha Vega e através do refletômetro, conforme ilustrações das Figuras 96 e 97, é possível medir as reflexões especulares nos ângulos de $60^{\circ}$ transversal e $60^{\circ}$ na longitudinal , conforme a Norma alemã DIN 5036-3 - que trata das propriedades radiométricas e fotométricas dos materiais, suas caracterísiticas, definições e grandezas.

Verifica-se que pelo processo PVD é posivel elevar am até 13\% as reflexçoes totais em relação ao alumínio anodizado padrão 100. Este material permitir uma economia de energia considerável de intensidade constante de luz e aumenta a eficácia dos aparelhos de iluminação na ordem de

$20 \%$.

Estas características tornam Vega um produto ideal para todas as aplicações que exigem uma reflexão alumínio de alta, como refletores e louvre, servindo principalmente para o retrofit de sitemas existentes, onde o interesse é elevar a eficiência energética.

\subsection{Características dos alumínios objeto deste estudo}

Os alumínios especulares utilizados na produção de luminárias se diferenciam pelas suas características físico-químicas, processo do tratamento de superfície e pela sua capacidade de reflexão e emissão de luz.

O alumínio nacional é encontrado no mercado em chapas e bobinas sem tratamento de anodização ou cortado em forma de disco ou superfícies retangulares e quadradas. O disco normalmente passa por um processo de repuxo para a confecção de luminárias com características cilíndricas, ou cortes retangulares ou quadrados na produção de projetores, recebendo uma anodização posterior.

Essa anodização nem sempre é perfeita, pois o disco, após a usinagem, lixamento e o repuxo, deve ser lavado com querosene ou detergente neutro para remoção de óxido e óleos; as peças não podem ter 
soldas ou componentes ferrosos prensados ou arrebitados, para receber a anodização.

Diferentes zonas de brilhos podem aparecer ao longo do perfil e as possíveis causas são a retenção de ar/gases, devido ao posicionamento inadequado das peças na gancheira, inibindo a migração do pigmento para o interior dos poros no tanque de anodização.

A camada anódica depositada também não é perfeita em toda a extensão das peças, o que diminui a capacidade reflexiva da luminária.

Figura 99 - Elevação das reflexões das superfícies dos sistemas óticos, conforme processo de anodização

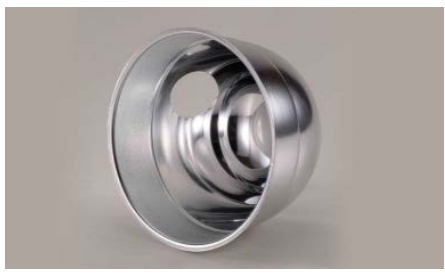

Sistema ótico com pós anodização

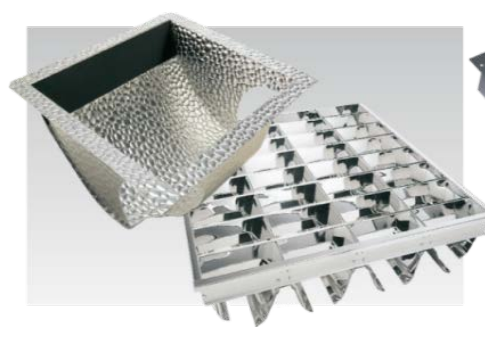

Sistemas óticos com pré -anodização

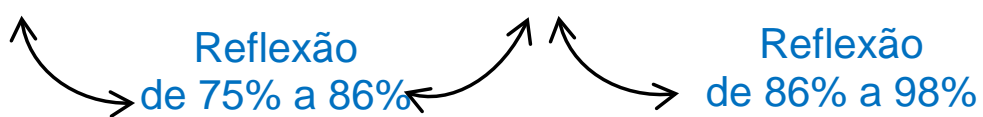

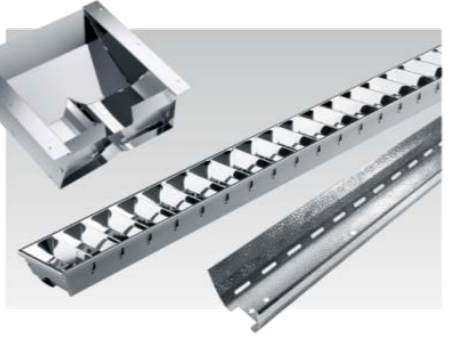

Sistemas óticos com processo PVD

Fonte: ALMECO, 2012.

Figura 100 - Reflexão total (\%) de distintos materiais metálicos

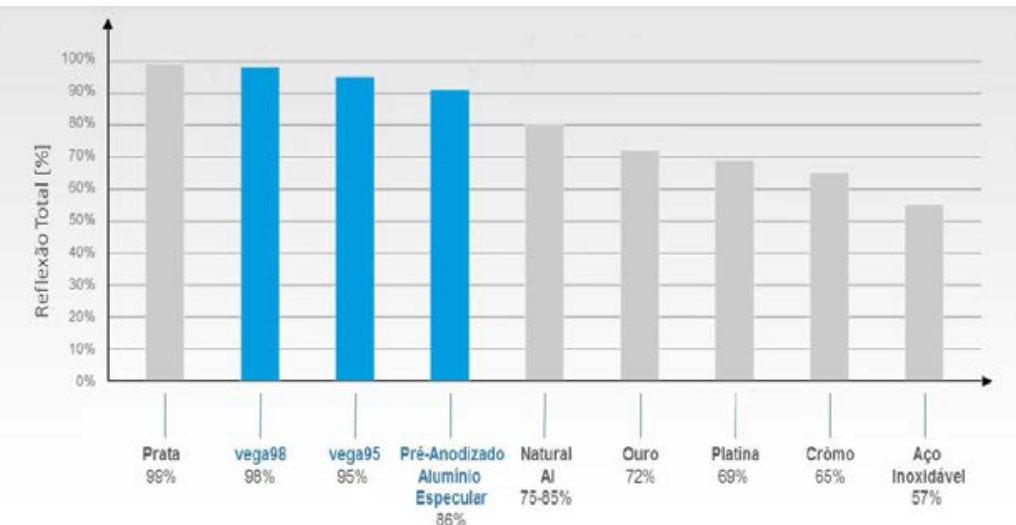

Fonte: ALMECO, 2012. 
A Figura 101 mostra a redução na intensidade da luz com múltiplas reflexões, considerando Alumínio pré-anodizado especular 100 (reflexão total -86\%), VEGA95100 (reflexão total 95\%) e VEGA 98100 (reflexão total 98\%) .

Figura 101 - Redução na intensidade da luz com múltiplas reflexões

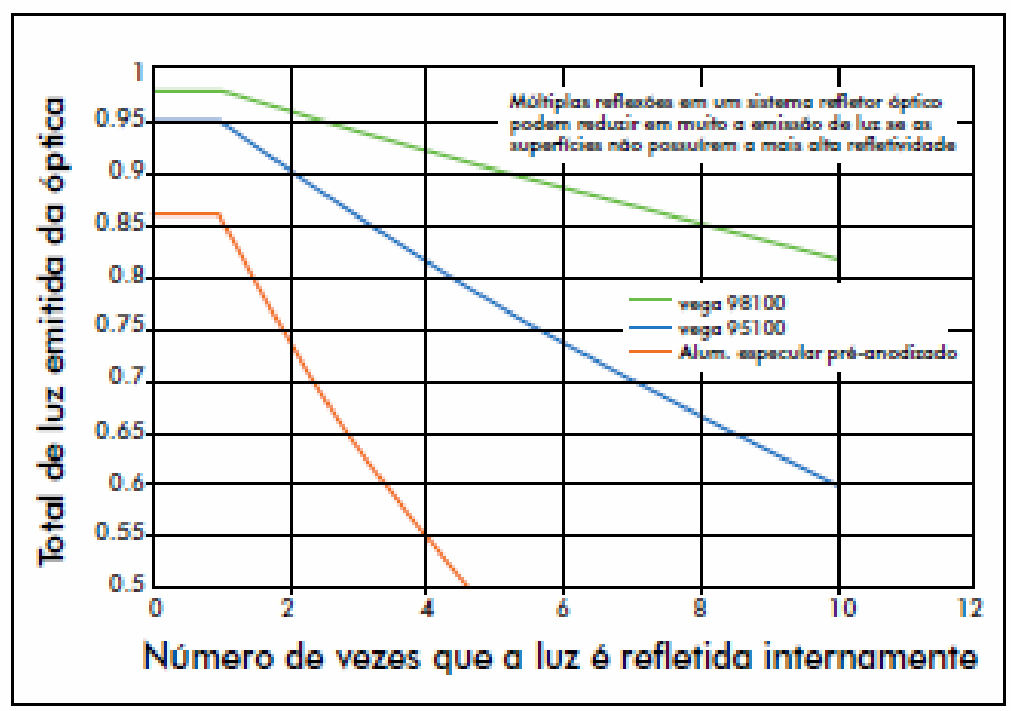

Fonte: ALMECO, 2012.

\subsection{Mercado nacional de alumínio utilizado na indústria de iluminação}

No Brasil, a maior parte do alumínio produzido é aplicada em embalagens e transportes, seguido da aplicação nos segmentos de eletricidade, construção civil, bens de consumo, máquinas e equipamentos duráveis. Embora existam fabricantes de alumínio primário no Brasil, sua produção é considerada inadequada para o uso no setor de iluminação. Dessa forma, o uso do alumínio importado é que abastece uma importante parcela do setor, porém o volume que se importa não justifica a instalação de uma linha de anodização, pois a capacidade de produção é maior que a de consumo (LASMAR).

Até 2009 , cerca de $20 \%$ a $30 \%$ dos fabricantes nacionais utilizavam o alumínio nacional sem anodização para a fabricação das suas luminárias comercais. Em 2012 tivemos uma alteração extremamente positiva, quando 90,65\% da indústria optou pela aquisição do alumínio anodizado, 2,15 \% pelo alumínio com tratamento PVD e 7,2\% pelo alumínio nacional sem 
anodização, conforme a estimativa do uso no mercado nacioanl, ilustrada na Figura 102.

Figura 102 - Estimativa do uso do alumínio no mercado nacional (t)

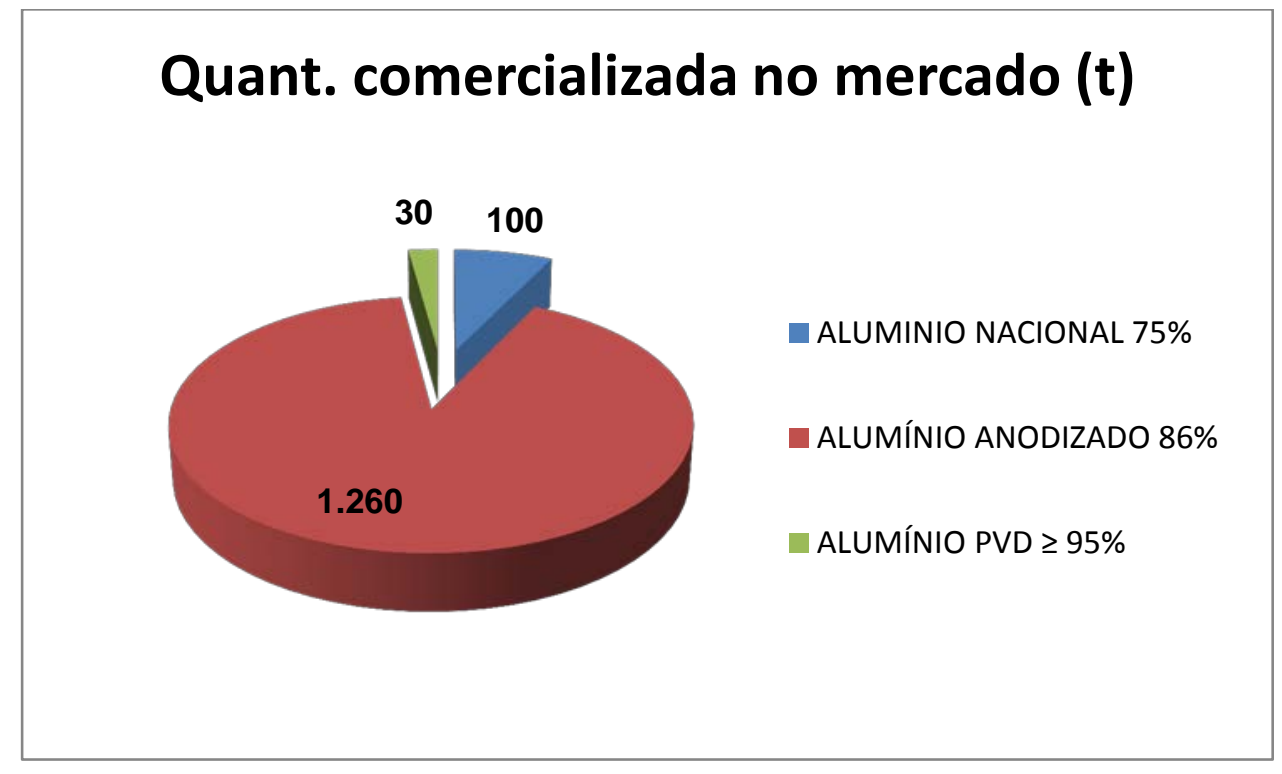

Fonte: ABAL, LUCCHI, SISCOMEX, 2012.

\subsection{Corrosão}

A corrosão consiste na deterioração dos materiais pela ação química ou eletroquímica do meio, podendo estar ou não associado a esforços mecânicos. Ao se considerar o emprego de materiais na construção de equipamentos instalações é necessário que estes resistam à ação do meio corrosivo, além de apresentar propriedades mecânicas suficientes e características de fabricação adequadas. A corrosão pode incidir sobre diversos tipos de materiais, sejam metálicos como os aços ou as ligas de cobre, por exemplo, ou não metálicos, como plásticos, cerâmicas ou concretas. A ênfase aqui descrita será sobre a corrosão dos materiais metálicos. Esta corrosão é denominada corrosão metálica.

Dependendo do tipo de ação do meio corrosivo sobre o material, os processos corrosivos podem ser classificados em dois grandes grupos, abrangendo todos os casos deterioração por corrosão: corrosão eletroquímica e corrosão química. 
Os processos de corrosão eletroquímica são mais frequentes na natureza e se caracterizam basicamente por:

- Necessariamente na presença de água no estado líquido;

- Temperaturas abaixo do ponto de orvalho da água, sendo a grande maioria na temperatura ambiente;

- Formação de uma pilha ou célula de corrosão, com a circulação de elétrons na superfície metálica.

Em face da necessidade do eletrólito conter água líquida, a corrosão eletroquímica é também denominada corrosão em meio aquoso.

Nos processos de corrosão, os metais reagem com os elementos não metálicos presentes no meio, $\mathrm{O} 2, \mathrm{~S}, \mathrm{H} 2 \mathrm{~S}, \mathrm{CO} 2$ entre outros, produzindo compostos semelhantes aos encontrados na natureza, dos quais foram extraídos. Conclui-se, portanto, que nestes casos a corrosão corresponde ao inverso dos processos metalúrgicos, vide Figura 102.

Figura 103 - Ciclo dos metais

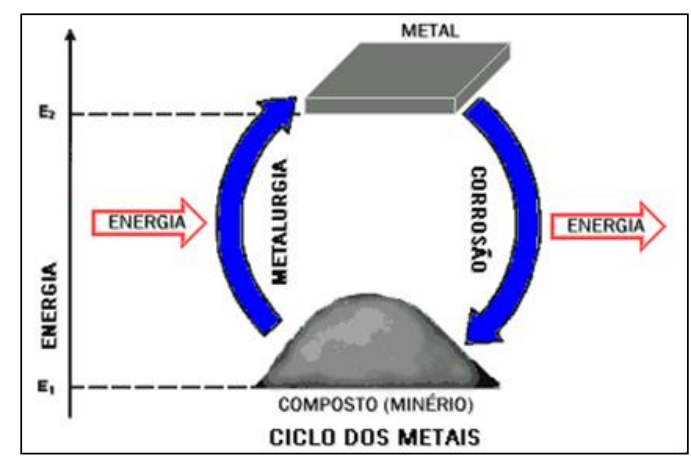

Fonte: GUTEMBERG, 2011.

Os processos de corrosão química são, por vezes, denominados corrosão ou oxidação em altas temperaturas. Estes processos são menos frequentes na natureza, envolvendo operações onde as temperaturas são elevadas.

Tais processos corrosivos se caracterizam basicamente por:

- Ausência da água líquida; 
- Temperaturas, em geral, elevadas, sempre acima do ponto de orvalho da água;

- Interação direta entre o metal e o meio corrosivo;

Como na corrosão química não se necessita de água líquida, ela também é denominada em meio não aquoso ou corrosão seca. Existem processos de deterioração de materiais que ocorrem durante a sua vida em serviço, que não se enquadram na definição de corrosão. Um deles é o desgaste devido à erosão, que remove mecanicamente partículas do material. Embora esta perda de material seja gradual e decorrente da ação do meio, tem-se um processo eminentemente físico e não químico ou eletroquímico.

Pode-se, entretanto ocorrer, em certos casos, ação simultânea da corrosão, constituindo o fenômeno da corrosão-erosão.

Outro tipo de alteração no material que ocorre em serviço são as transformações metalúrgicas que podem acontecer em alguns materiais, particularmente em serviço com temperaturas elevadas. Em função destas transformações as propriedades mecânicas podem sofrer grandes variações, por exemplo, apresentando excessiva fragilidade na temperatura ambiente.

A alteração na estrutura metalúrgica em si não é corrosão embora possa modificar profundamente a resistência à corrosão do material, tornando-o, por exemplo, susceptível à corrosão intergranular.

Durante o serviço em alta temperatura pode ocorrer também o fenômeno da fluência, que é uma deformação plástica do material crescente ao longo do tempo, em função da tensão atuante e da temperatura.

\subsubsection{Meios corrosivos}

Os meios corrosivos em corrosão eletroquímica são responsáveis pelo aparecimento do eletrólito. O eletrólito é uma solução eletricamente condutora constituída de água contendo sais, ácidos ou bases. 
Principais meios corrosivos e contaminantes:

- Atmosfera: o ar contém umidade, os sais em suspensão, gases industriais, poeira, etc. O eletrólito constitui-se da água que condensa na superfície metálica, na presença de sais ou gases presentes no ambiente. Outros constituintes como poeira e poluentes diversos podem acelerar o processo corrosivo;

- As concentrações dos principais contaminantes na atmosfera estão apresentadas na Tabela 32. Entre estes contaminantes os óxidos de enxofre e, principalmente, o dióxido de enxofre, exercem uma influência importante sobre a corrosão atmosférica dos aços e do zinco. As duas principais fontes de dióxido de enxofre na atmosfera são a oxidação atmosférica do ácido sulfídrico $\left(\mathrm{H}_{2} \mathrm{~S}\right)$, produzido pela decomposição de compostos orgânicos contendo enxofre, e a queima de combustíveis contendo enxofre. A última destas fontes predomina em países industrializados.

Tabela 32 - Concentrações típicas de impurezas na atmosfera

\begin{tabular}{|c|c|c|}
\hline & \multicolumn{2}{|c|}{ Concentrações $\left(\mu \mathrm{g} \mathrm{m}^{-3}\right)$} \\
\hline Impureza & Região industrial & Região rural \\
\hline Dióxido de enxofre & $100-350$ & $40-100$ \\
\hline Trióxido de enxofre & $1-3,5$ & $0,4-1$ \\
\hline Ácido sulfúrico & $1,5-90$ & $0,15-0,45$ \\
\hline Amônia & 4,8 & 2,1 \\
\hline Cloreto & $2,7-8,2$ & 5,4 \\
\hline Particulas de fumaça & $100-250$ & $15-60$ \\
\hline
\end{tabular}

Fonte: Universidade Federal do Paraná, 2012.

- Além dos contaminantes citados a corrosão atmosférica é influenciada por um conjunto de fatores, muitas vezes interrelacionados: temperatura, umidade relativa como orvalho, condensação e mesmo chuva, na ausência da umidade, a maioria dos contaminantes teria pouco ou nenhum efeito, direção dos ventos e velocidade dos ventos, radiação solar, pluviosidade, condensação e etc. 
- Os materiais mais empregados como resistentes aos diferentes tipos de atmosferas são: cobre chumbo, alumínio e aço galvanizado. $\mathrm{O}$ aço carbono, com pequena quantidade de cobre, também é resistente à corrosão atmosférica uma vez que o cobre auxilia na formação de uma película protetora sobre o aço. Pequenas quantidades de níquel e cromo são úteis em atmosferas industriais, pois formam sulfatos insolúveis que protegem o metal.

- Outro fenômeno importante também ocorre quando os materiais estão expostos à atmosfera. Com a diminuição da temperatura ambiente nos períodos noturnos, ocorre condensação de umidade em regiões da estrutura metálica onde a evaporação está dificultada e, portanto, o ataque do metal. Um bom exemplo deste fenômeno, denominado corrosão protegida, é a corrosão que ocorre nas partes internas das portas dos automóveis. Para se evitar este tipo de corrosão deve-se cobrir o metal com películas protetoras.

- Solos: os solos contêm umidade, sais minerais e bactérias. Alguns solos apresentam também, características ácidas ou básicas. O eletrólito constitui-se principalmente da água com sais dissolvidos; - Águas naturais (rios, lagos e do subsolo): estas águas podem conter sais minerais, eventualmente ácidos ou bases, resíduos industriais, bactérias, poluentes diversos e gases dissolvidos. O eletrólito constitui-se principalmente da água com sais dissolvidos.

Os outros constituintes podem acelerar o processo corrosivo;

- Água do mar: estas águas contêm uma quantidade apreciável de sais. Uma análise da água do mar apresenta em média os seguintes constituintes em gramas por litro de água.

- A água do mar em virtude da presença acentuada de sais é um eletrólito por excelência. Outros constituintes como gases dissolvidos, podem acelerar os processos corrosivos; 
- O ambiente marinho é o mais corrosivo de todos os meios naturais, e compreende desde a atmosfera contaminada com sal do mar até regiões mais profundas do oceano e o lodo sobre o fundo do mar. Os componentes e estruturas que estão normalmente expostos a meios marítimos são, por exemplo, as bombas e tubulações de água do mar, navios, submarinos, cais, estacas e plataformas de petróleo costeiras.

- Produtos químicos: os produtos químicos, desde que em contato com água ou com umidade e formem um eletrólito, podem provocar corrosão eletroquímica.

- Corrosão biológica - A atividade biológica de organismos vivos presentes em um dado meio (água, solo, etc.) pode afetar, direta ou indiretamente, o processo de corrosão de um metal. O processo de deterioração de um metal provocado pela atividade biológica de organismos vivos é denominado de corrosão biológica.

- Observa-se que os organismos vivos vivem e se reproduzem em meios de $\mathrm{pH}$ entre 0 e 11, à temperaturas de 0 a $80^{\circ} \mathrm{C}$ e sob pressões de até 1000 atm. Portanto, a atividade dos organismos vivos pode afetar a corrosão de um metal numa grande variedade de ambientes.

- Influenciando diretamente as reações anódica e catódica;

- Influenciando as películas protetoras formadas sobre o metal;

- Criando condições corrosivas;

- Produzindo depósitos;

- Vale ressaltar que os efeitos citados podem ocorrer de forma única ou combinados dependendo do ambiente e do organismo envolvido.

- Os organismos vivos podem existir nas formas micro, como as bactérias, e nas formas macro, como as algas. 0 mecanismo pelo qual as diferentes formas de organismos afetam a velocidade de corrosão de um metal são: 
- Micro-organismos: são classificados de acordo com sua capacidade de crescer em presença ou ausência de oxigênio. Os micro-organismos que necessitam de oxigênio no seu processo metabólico são chamados de aeróbicos; os que não necessitam de oxigênio são chamados anaeróbicos.

- Macro-organismos: dentre os milhares de tipos de macro-organismos podem-se destacar: fungos, mofos, crustáceos, moluscos e algas. Fungos e mofos pertencem a um grupo de plantas que se caracterizam pela deficiência de clorofila. Estas espécies assimilam matéria orgânica e produzem quantidades consideráveis de ácidos orgânicos, tais como ácidos oxálico, lático, acético ou cítrico. Os fungos podem atacar borrachas e superfícies com ou sem revestimentos. O crescimento de fungos e mofos pode ser eliminado ou reduzido fazendo-se limpezas periódicas. A diminuição da umidade relativa e o emprego de agentes orgânicos tóxicos (violeta genciana, por exemplo) também são eficazes na redução de fungos de superfície metálicas. 


\section{RESULTADOS DOS ENSANOS}

\subsection{Procedimentos utilizados para os ensaios}

A seguir são apresentados os relatórios com as tabulações, conforme ferramenta adotada para as medições fotométricas obtidas nos ensaios no Laboratório de Fotometria da Carolino Indústria e Comércio Ltda.

Os relatórios apresentam:

- Especificação técnica e características gerais;

- Intensidades luminosas nos eixos transversal e longitudinal;

- Iluminâncias;

- Constantes zonais;

- Rendimentos.

Condições em laboratório:

A precisão e exatidão das medições estão diretamente ligadas a utilização de procedimentos padronizados e bons equipamentos e, embora não exista nenhuma norma brasileira própria para os ensaios fotométricos, foi necessário manter alguns procedimentos específicos para este fim, recomendados pela CIE e IESNA (1995).

Os ensaios foram realizados seguindo alguns destes padrões:

- Quanto à alimentação elétrica, o reator foi operado em sua tensão e frequência nominal. Durante os ensaios observou-se o período de estabilização e de controle da tensão mantida constante e com variação máxima de 0,5\%;

- O reator eletrônico de padrão de referência secundário RE028 foi identificado e guardado quando fora do período de uso em laboratório; 
- As lâmpadas de padrão de referência secundário FL028 e FL028A foram identificadas, embaladas e guardadas quando fora do período de uso em laboratório;

- Os principais equipamentos fotométricos utilizados nas medições foram elencados no item 2.5.2.1.

- Goniofotômetro manual - Laboratório Carolino Indústria e Comercio Ltda.

- Luxímetro MINOLTA, modelo T-10

- Estabilizador de tensão linear - modelo 1000 TRA-BB/13, fabricante TECTROL

- Os ensaios fotométricos foram realizados e as iluminâncias foram medidas em intervalos de ângulos de $5^{\circ}$ nos planos transversal e longitudinal, e as intensidades luminosas foram obtidas pelas multiplicações das iluminâncias medidas e o quadrado da distância entre o centro fotométrico da luminária e o fotômetro do luxímetro, sendo o ponto fotométrico da luminária o que está sobre a linha resultante da intersecção do eixo de referência. A distância (d) para o fotômetro do luxímentro ao centro fotométrico da luminária foi de seis metros.

Figura 104 - Distância entre o goniofotômetro e a fotocélula do luxímetro.

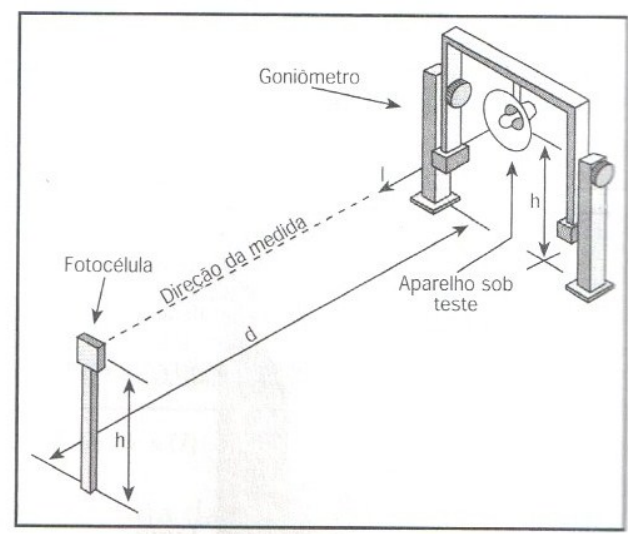

Fonte: Moreira, 2006.

- O período de intervalo de ensaio entre as luminárias não foi superior a 15 minutos. Desta forma, podemos considerar que as variações de fluxo luminoso não foram superiores a 0,5\% de lâmpadas e luminárias. 
7.2. Resultados dos ensaios dos conjuntos óticos de referência -R A1, R B1 e R C1

\subsubsection{Ensaio do conjunto ótico de referência - R A1}

Tabela 33 - Tabulação do conjunto ótico de referência - R A1
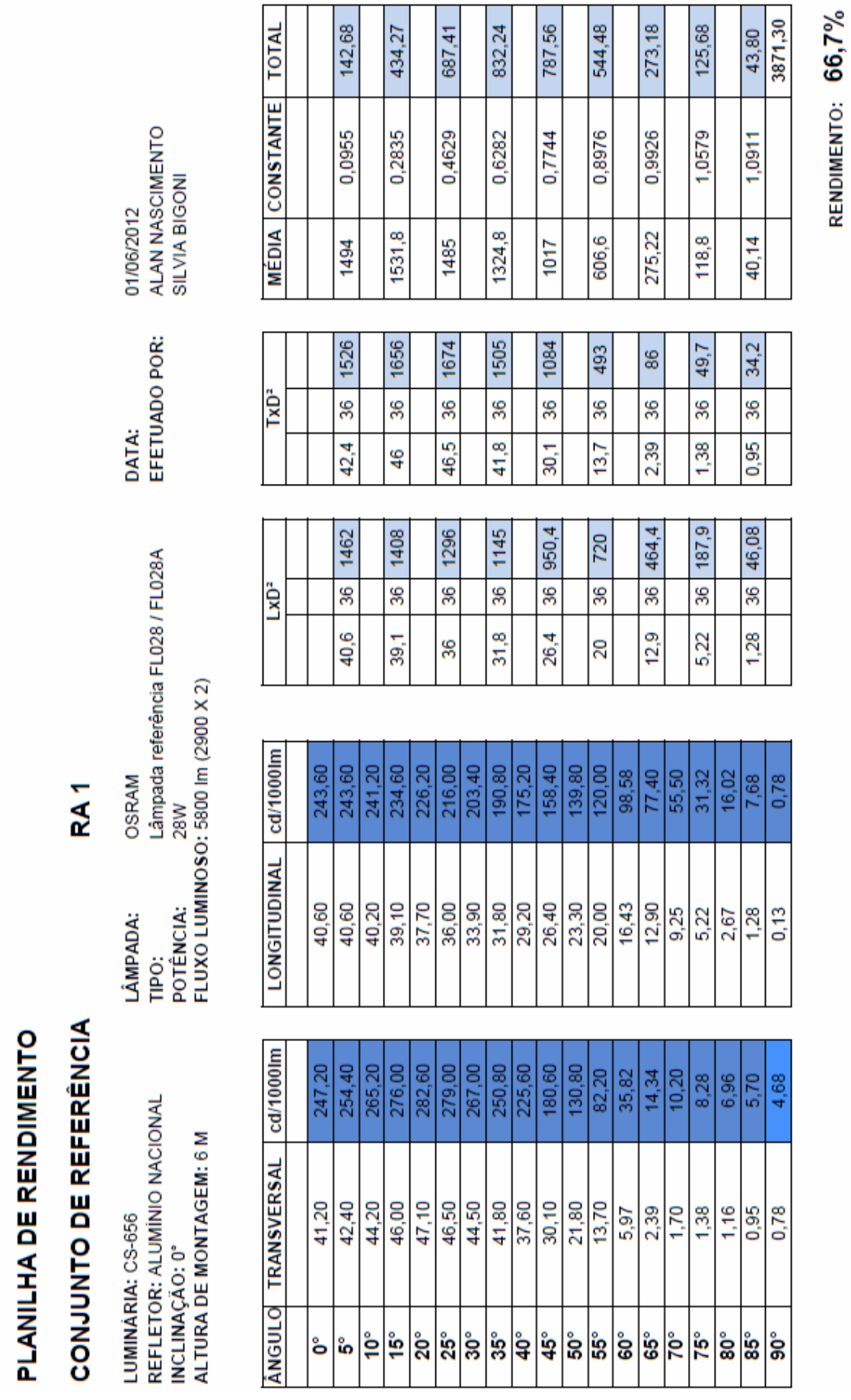


\subsubsection{Ensaio do conjunto ótico de referência - R B1}

Tabela 34 - Tabulação do conjunto ótico de referência - R B1
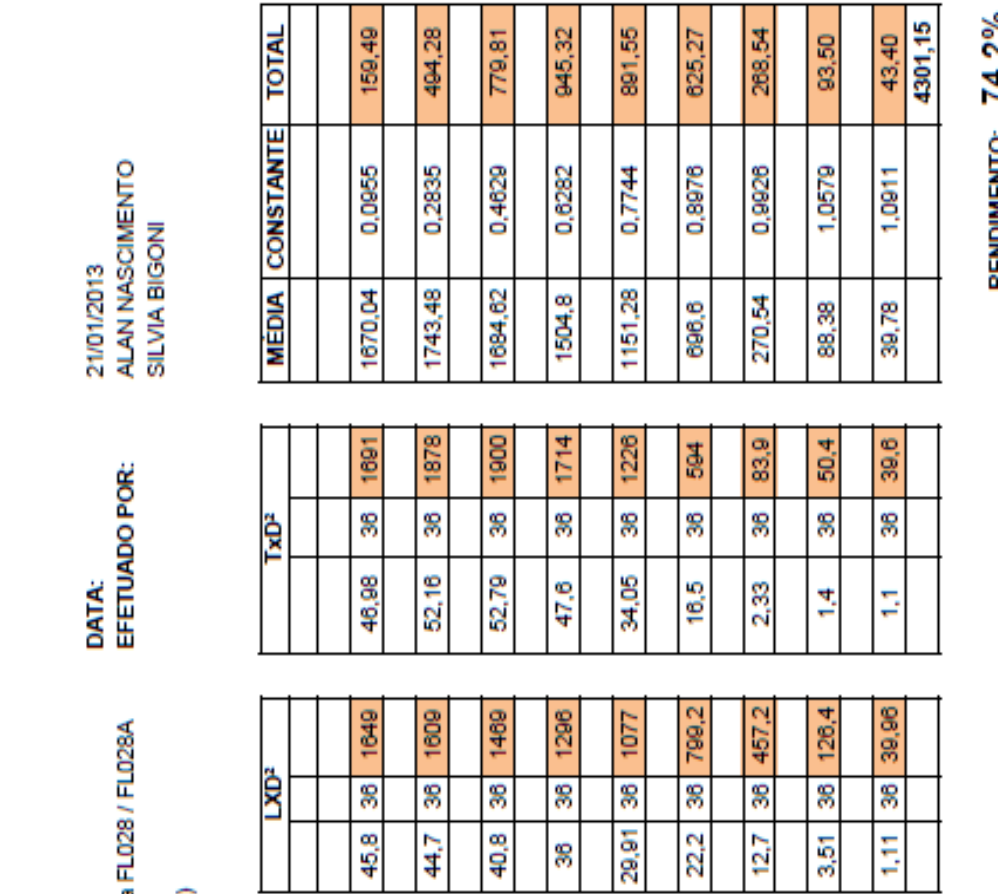

$$
\text { . }
$$

要

-

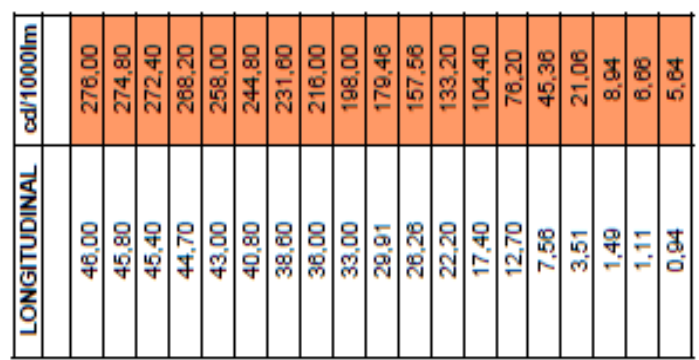

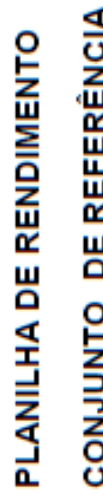
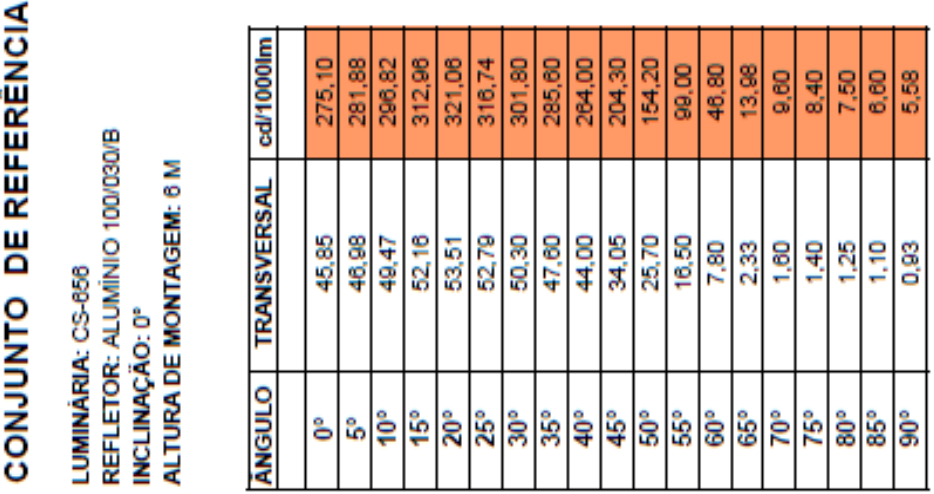

Fonte: a autora, 2013. 
7.2.3. Ensaio do conjunto ótico de referência - R C1

Tabela 35 - Tabulação do conjunto ótico de referência - R C1
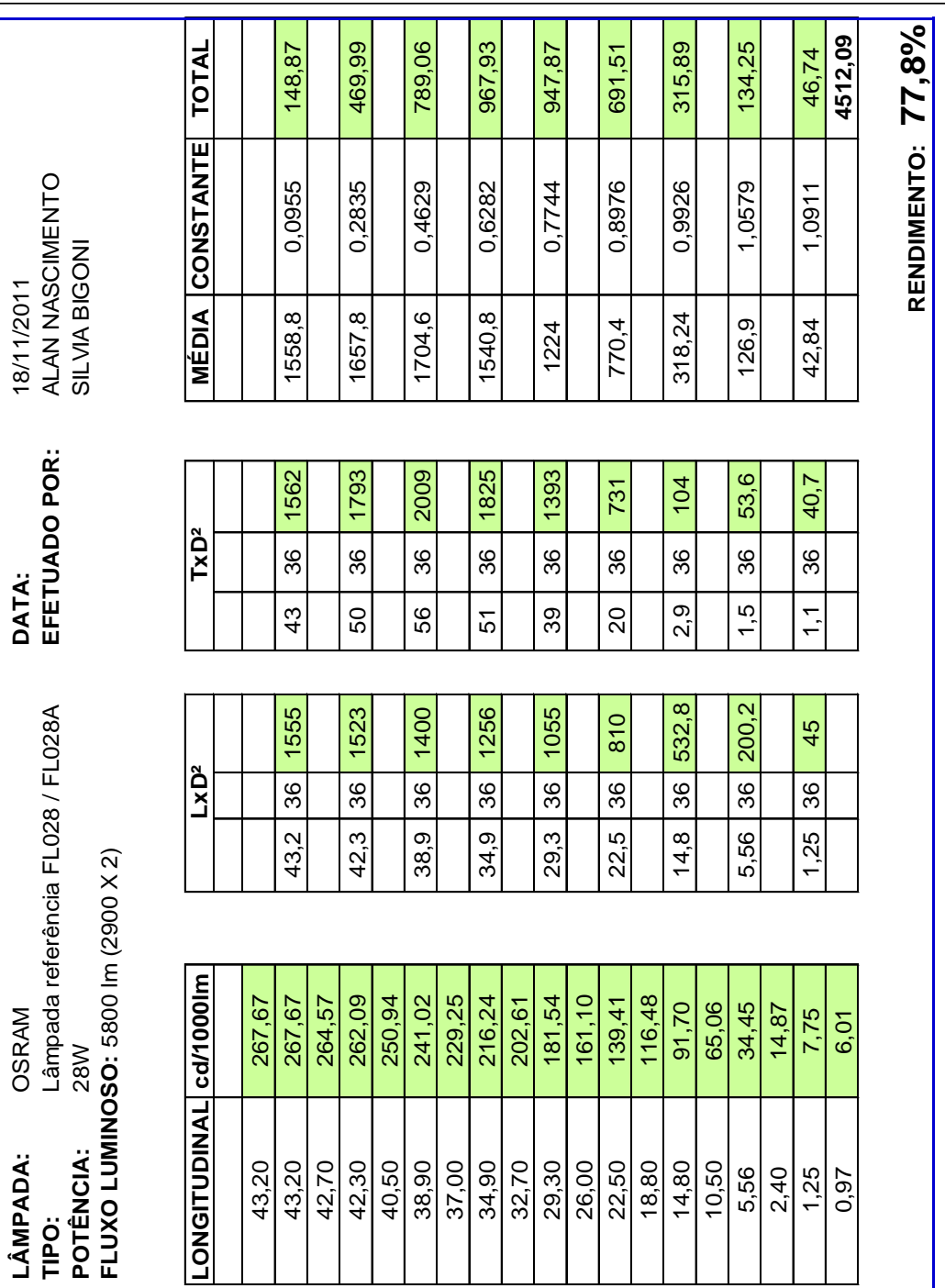

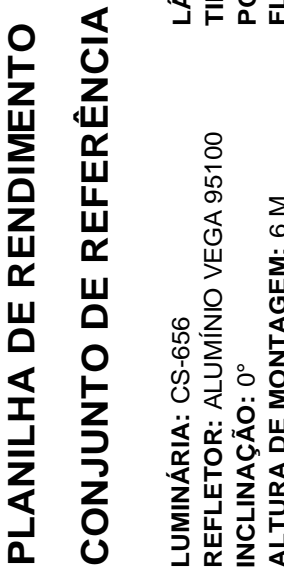

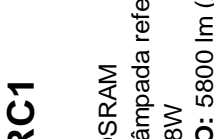

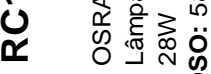

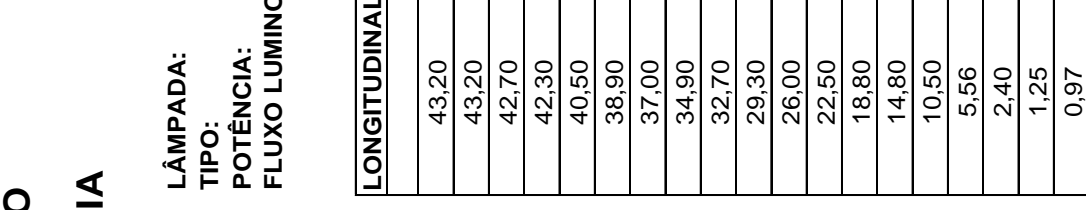

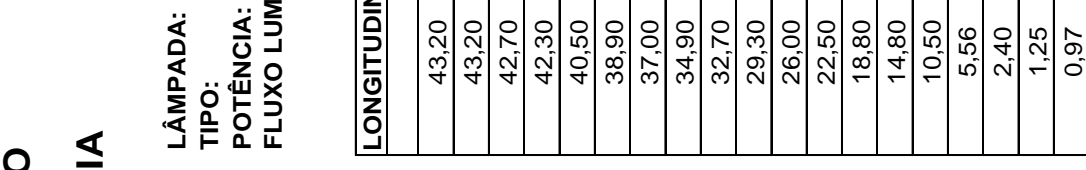

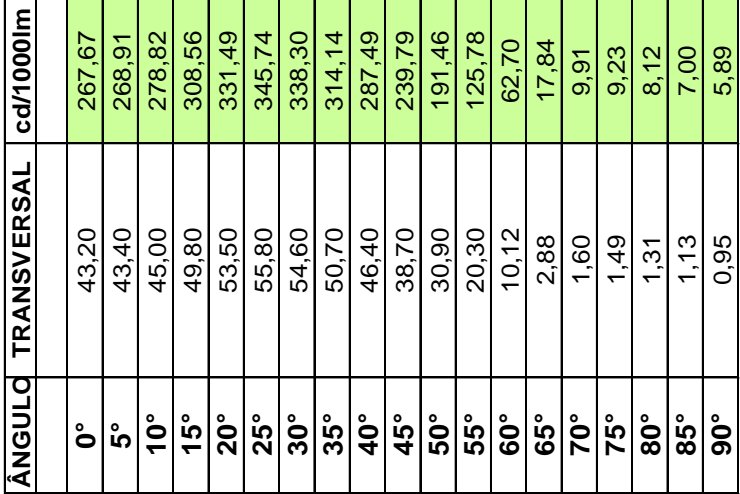

Fonte: a autora, 2013. 
7.3. Resultados dos ensaios das luminárias de campo - Instalação 1 - FASA Fibra Ótica, Peruíbe, SP - FA A1, FA B1, FA C1

\subsubsection{Ensaio da luminária de ensaio - FA A1 (1.512 horas)}

Tabela 36 - Tabulação da luminária de ensaio - Instalação 1 - FASA Fibra Ótica, Peruíbe, SP - FA A1.

Período da instalação: 1.512 horas
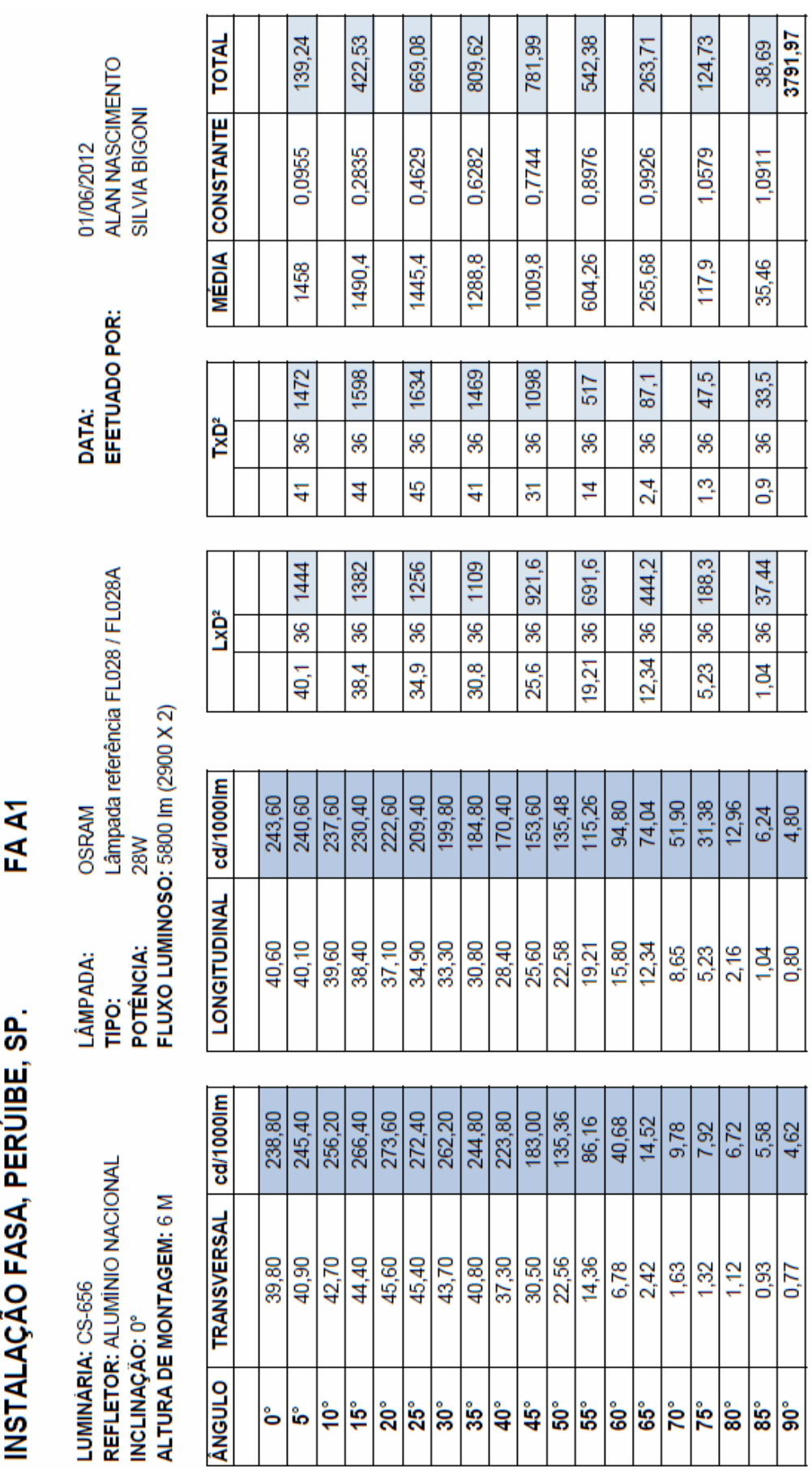

Fonte: a autora, 2013. 


\subsubsection{Ensaio da luminária de ensaio - FA A1 (2.640 horas)}

Tabela 37 - Tabulação da luminária de ensaio - Instalação 1 - FASA Fibra Ótica, Peruíbe, SP - FA A1

Período da instalação: 2.640 horas

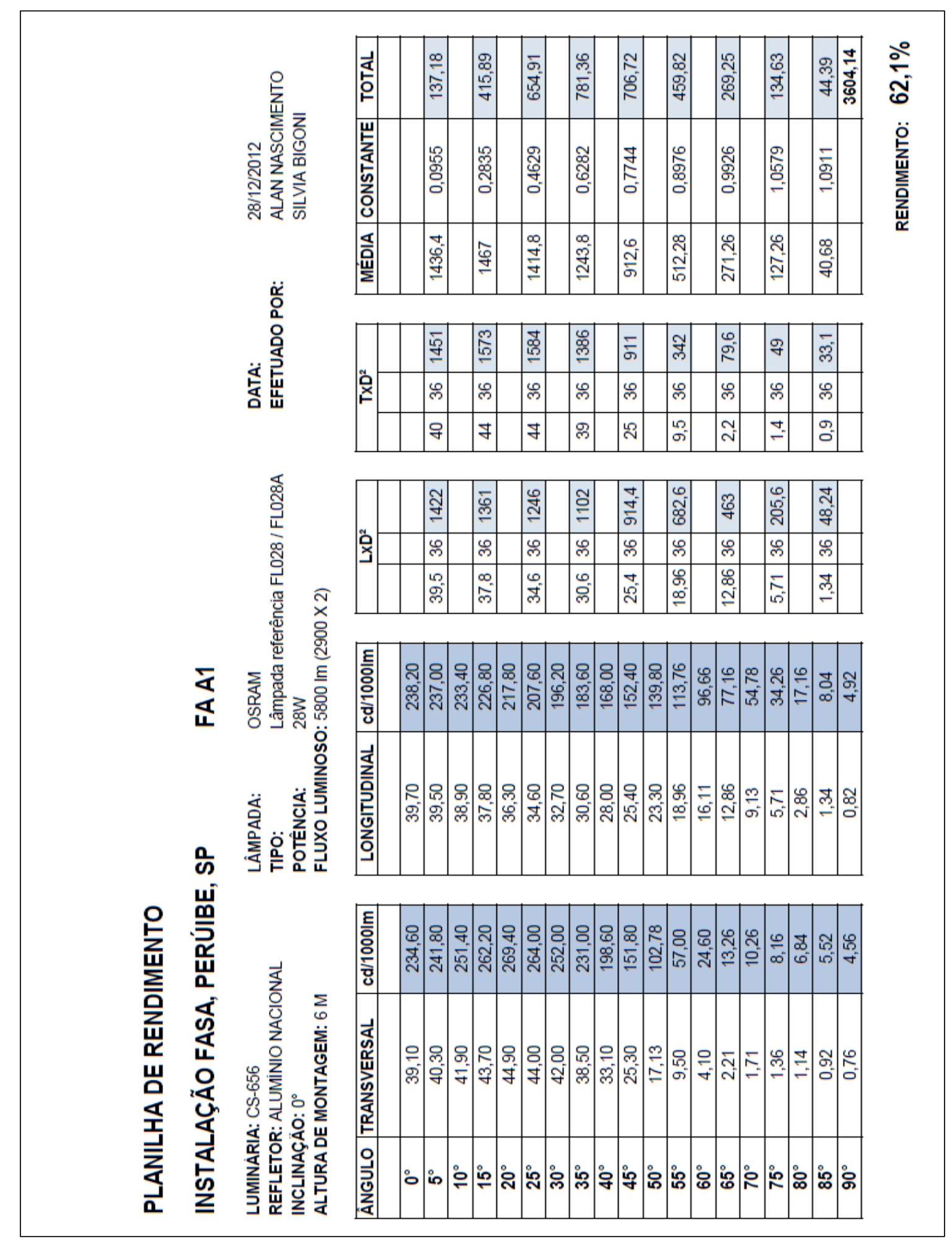

Fonte: a autora, 2013. 


\subsubsection{Ensaio da luminária de ensaio - FA B1 (1.512 horas)}

Tabela 38 - Tabulação da luminária de ensaio - Instalação 1 - FASA Fibra Ótica, Peruíbe, SP - FA B1.

Período da instalação: 1.512 horas.
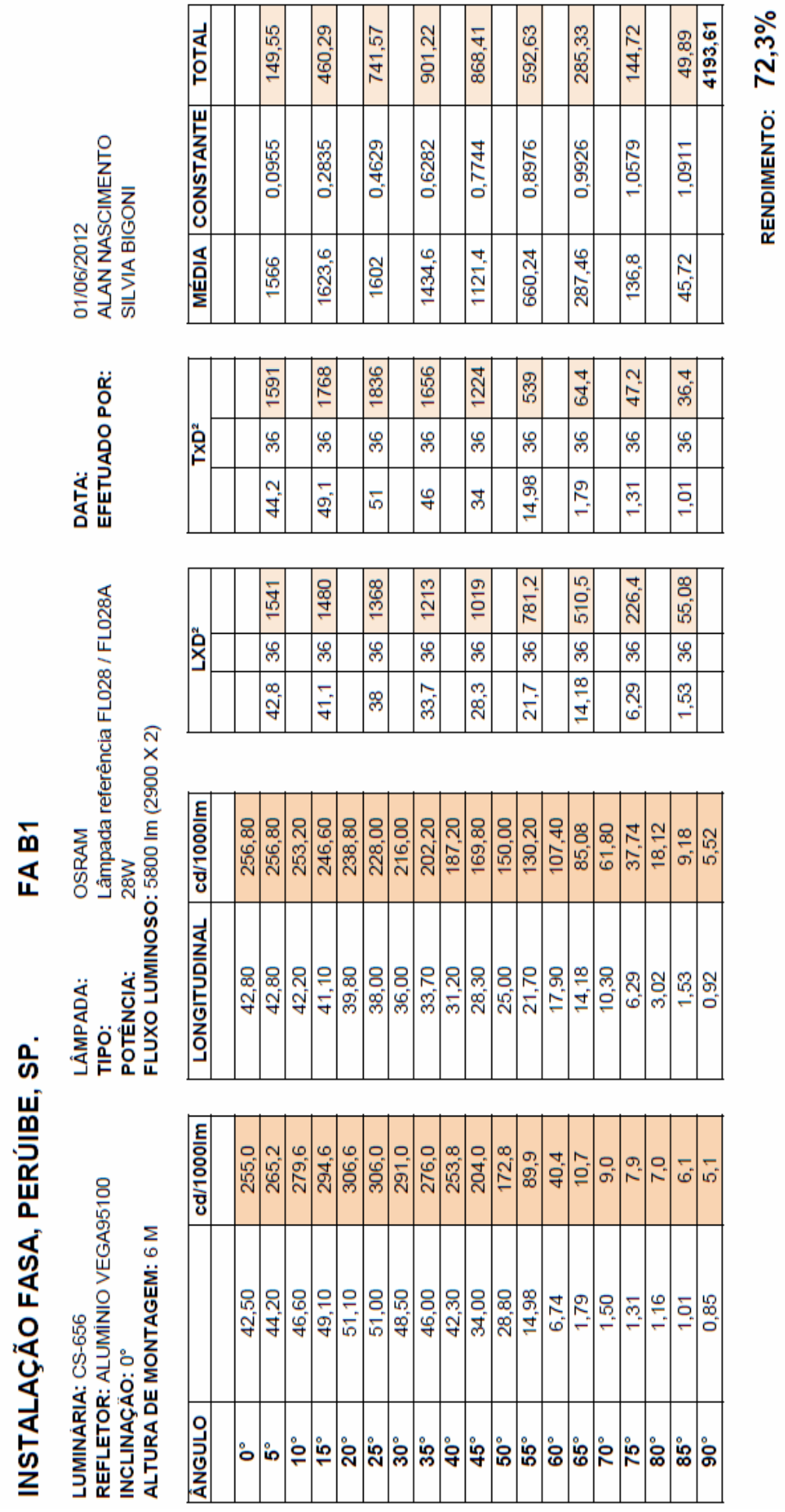

Fonte: a autora, 2013. 
7.3.4. Ensaio da luminária de ensaio- FA B1 (2.640 horas)

Tabela 39 - Tabulação da luminária de ensaio - Instalação 1 - FASA Fibra Ótica, Peruíbe, SP - FA B1

Período da instalação: 2.640 horas
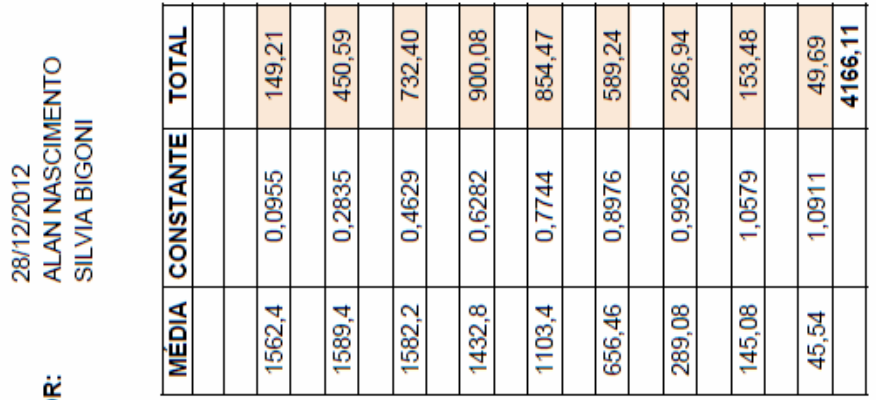

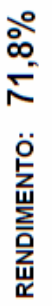

产

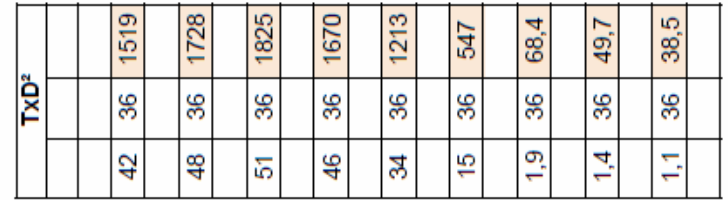

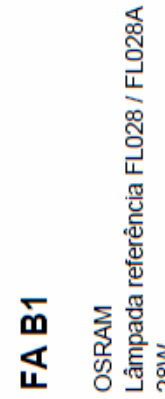

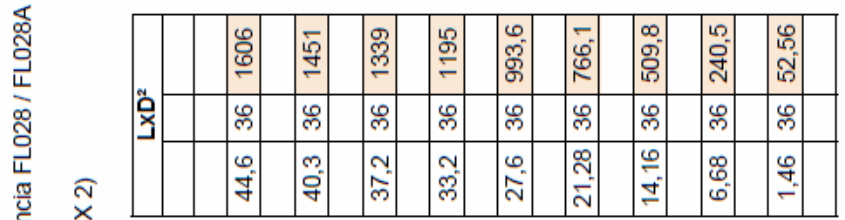

एँ.

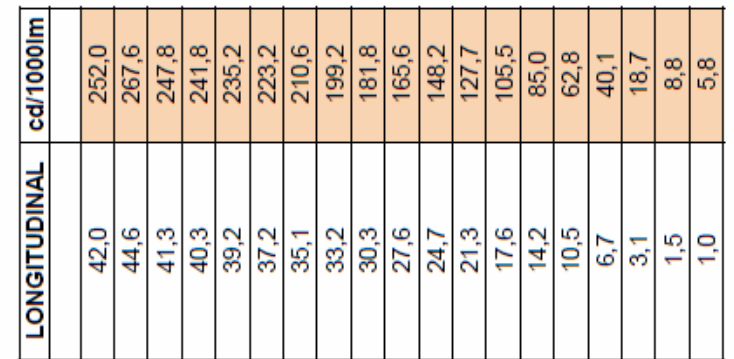

올

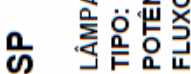

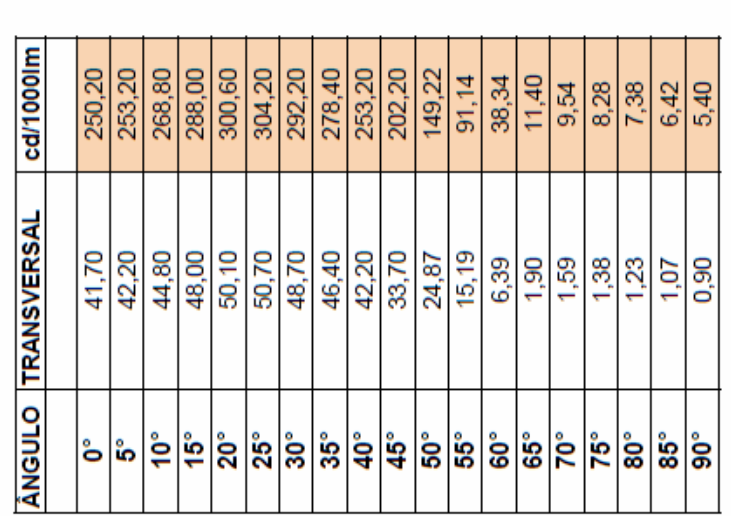

Fonte: a autora, 2013. 
7.3.5. Ensaio da luminária de ensaio - FA C1 (1.512 horas)

Tabela 40 - Tabulação da luminária de ensaio - Instalação 1 - FASA Fibra Ótica, Peruíbe, SP - FA C1.

Período da instalação: 1.512 horas
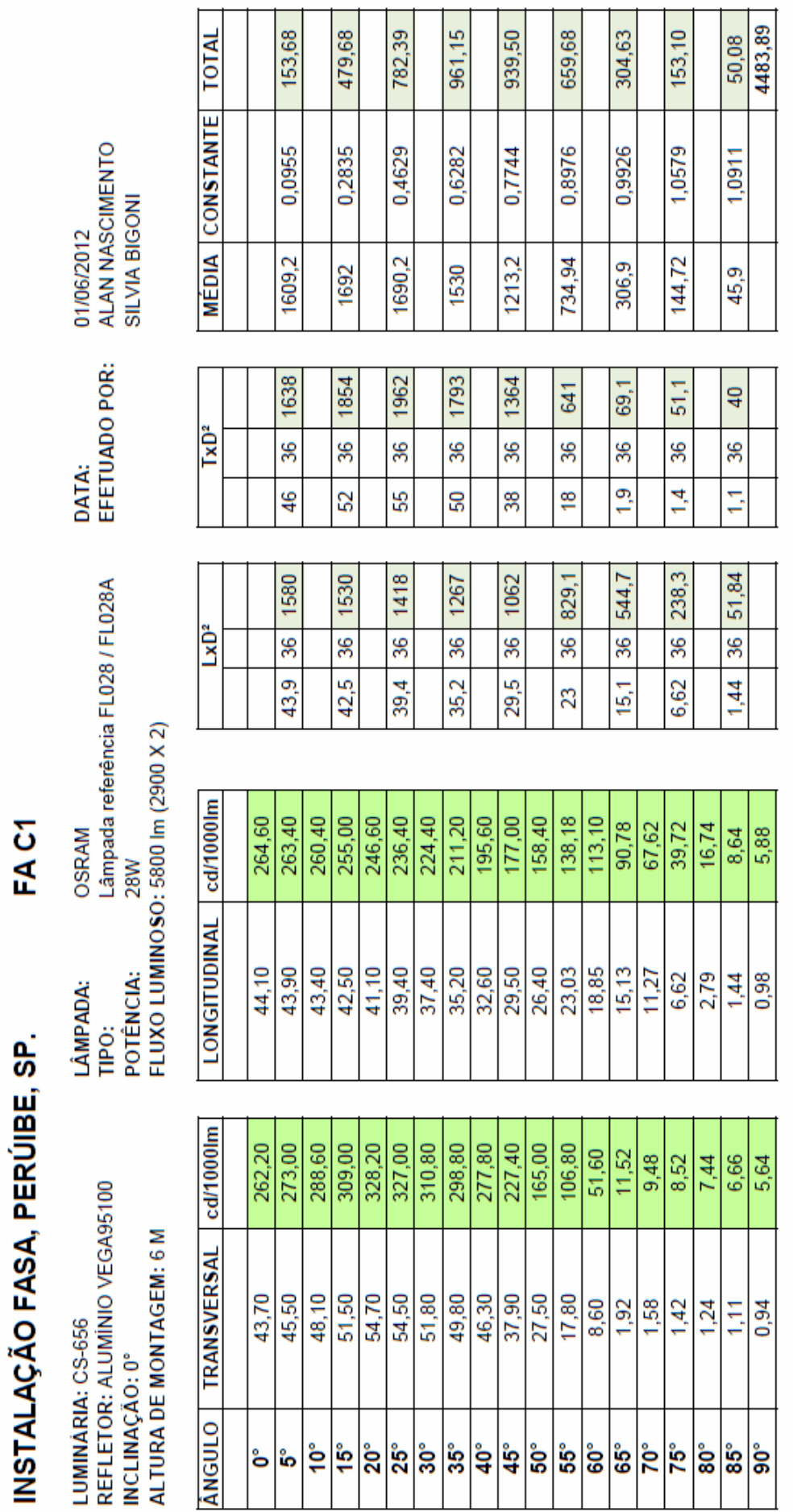

Fonte: a autora, 2013. 


\subsubsection{Ensaio da luminária de ensaio FA C1 (2.640 horas)}

Tabela 41 - Tabulação da luminária de ensaio - Instalação 1 - FASA Fibra Ótica, Peruíbe, SP - FA C1.

Período da instalação: 2.640 horas
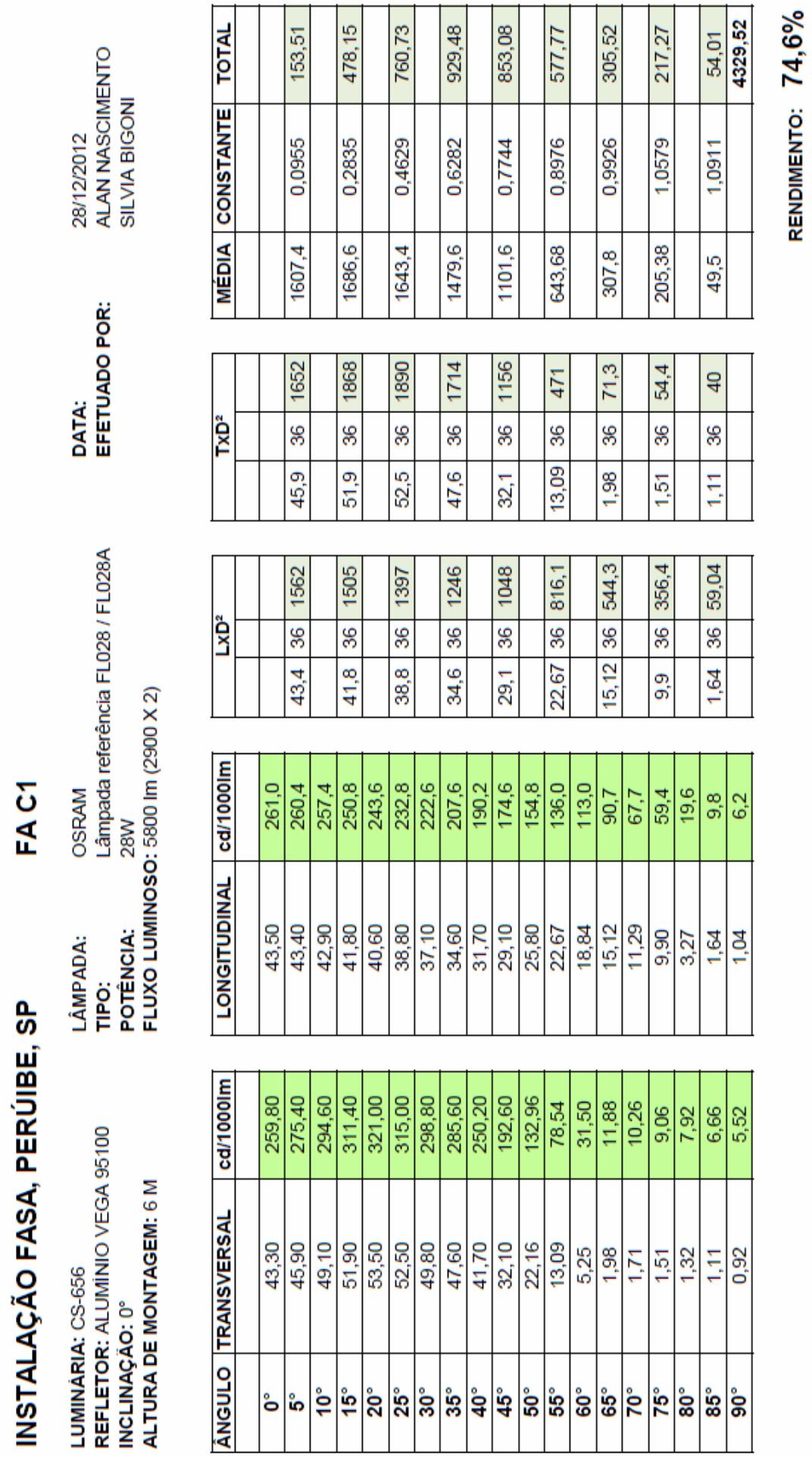

Fonte: a autora, 2013. 
7.4. Resultados dos ensaios das luminárias de campo - Instalação 2 LUCCHI Ltda., Cotia, SP - LU A1, LU B1 e LU C1

\subsubsection{Ensaio da luminária de ensaio LU A1 (1.576 horas)}

Tabela 42 - Tabulação da luminária de ensaio - Instalação 2 - LUCCHI Ltda, Cotia, SP - LU A1.

Período da instalação: 1.576 horas
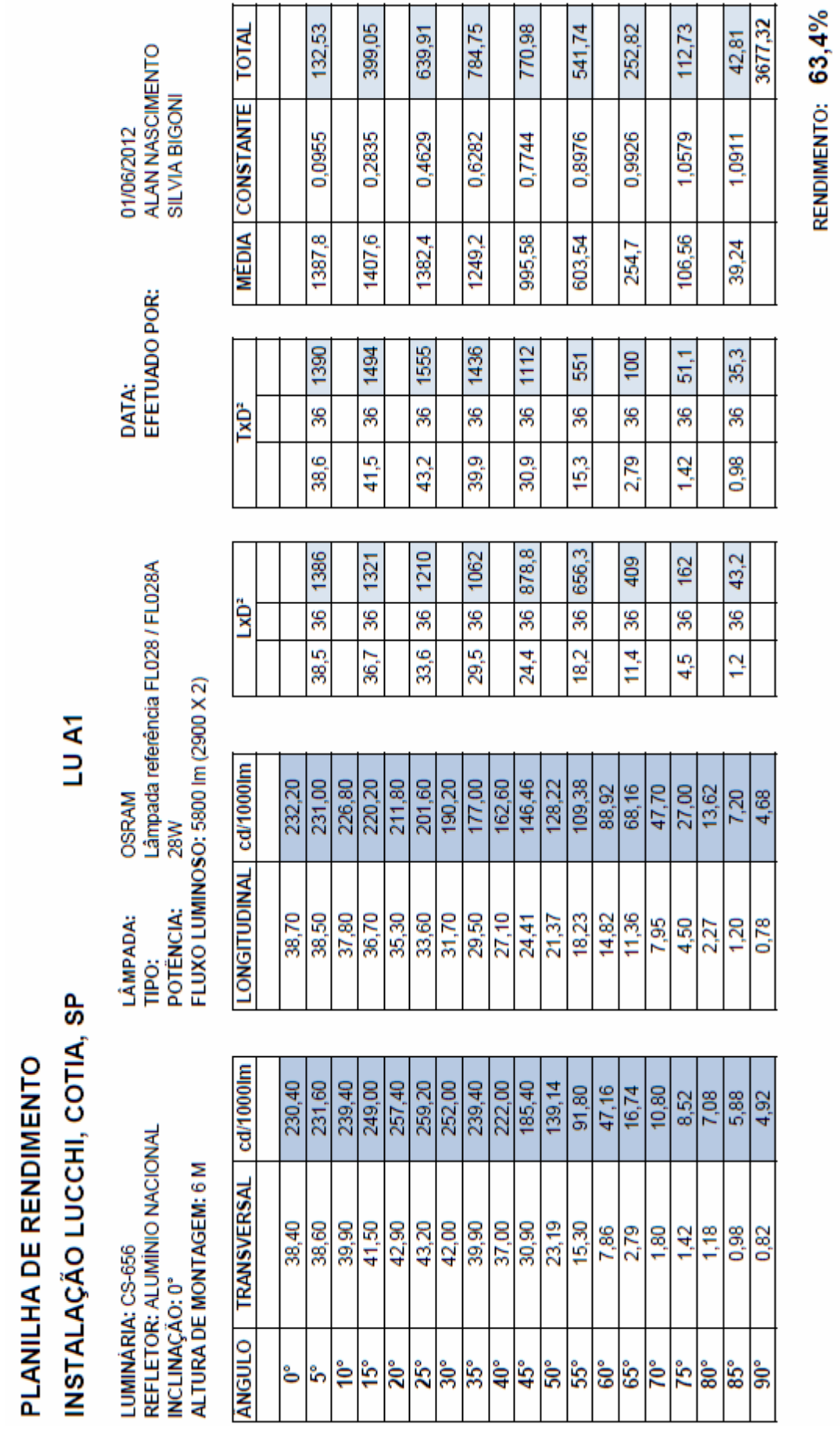

Fonte: a autora, 2013. 


\subsubsection{Ensaio da luminária de ensaio LU A1 ( 2.720 horas)}

Tabela 43- Tabulação da luminária de ensaio - Instalação 2 - LUCCHI Ltda, Cotia, SP - LU A1.

Período da instalação: 2.720 horas.

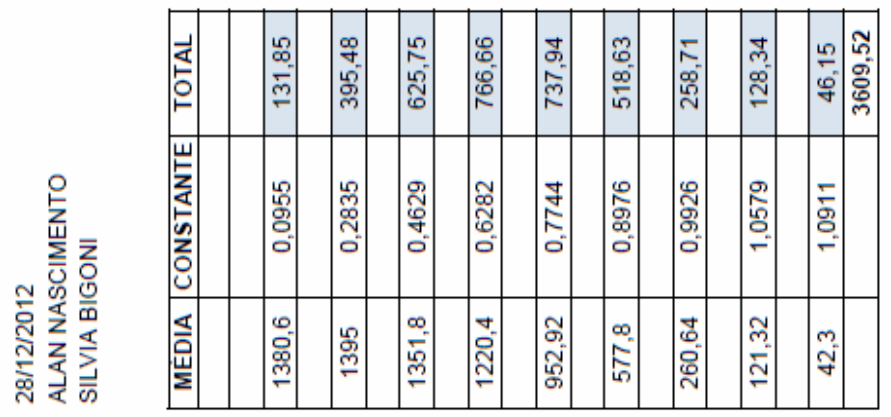

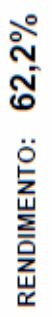

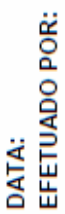
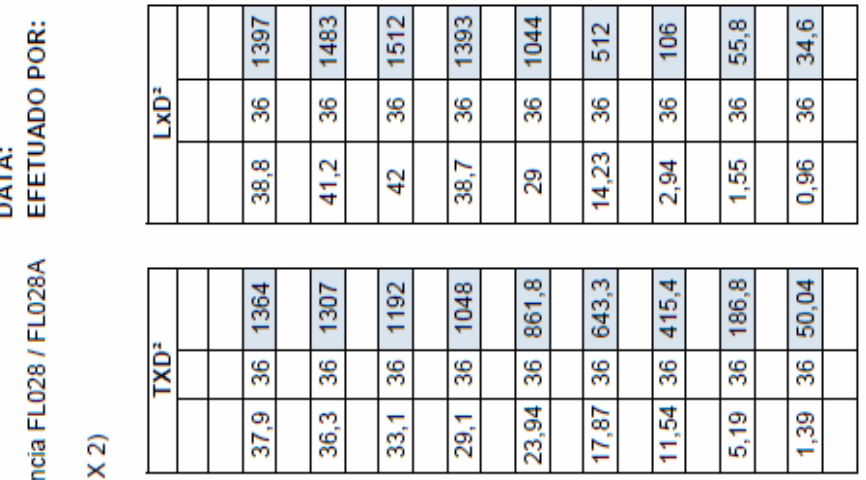

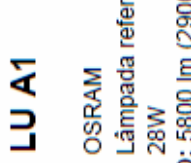

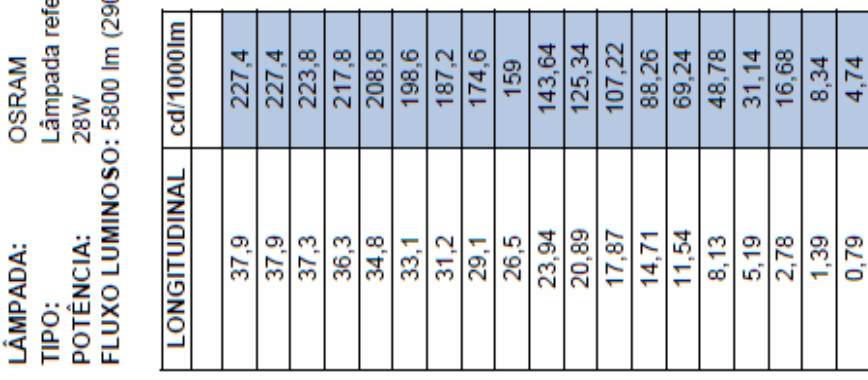

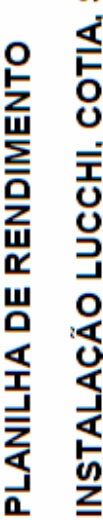

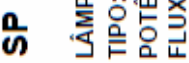

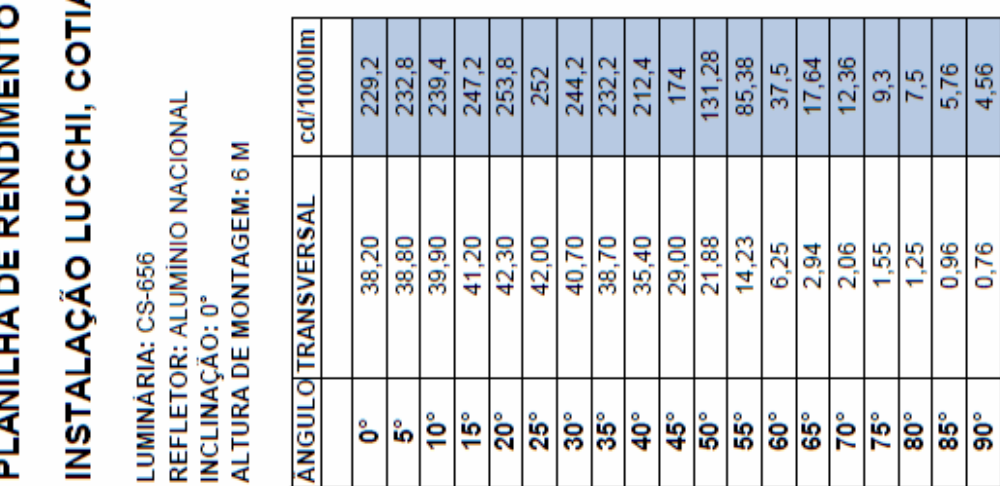

Fonte: a autora, 2013. 


\subsubsection{Ensaio da luminária de ensaio- LU B1 (1.576 horas)}

Tabela 44 - Tabulação da luminária de ensaio - Instalação 2 - LUCCHI Ltda, Cotia, SP - LU B1.

Período da instalação: 1.576 horas
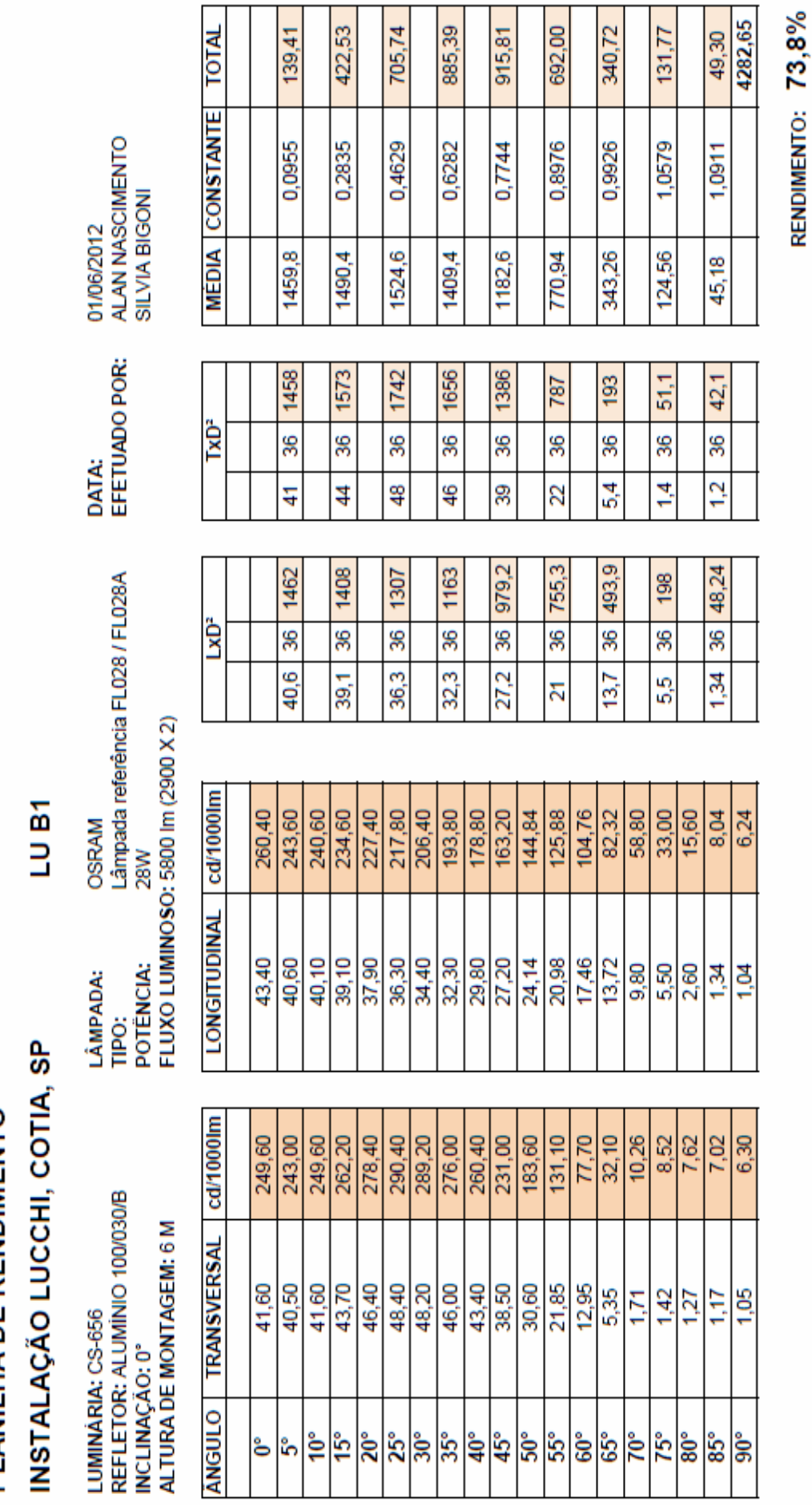

Fonte: a autora, 2013 


\subsubsection{Ensaio da luminária de ensaio- LU B1 (2.720 horas)}

Tabela 45 - Tabulação da luminária de ensaio - Instalação 2 - LUCCHI Ltda, Cotia, SP - LU B1.

Período da instalação: 2.720 horas.
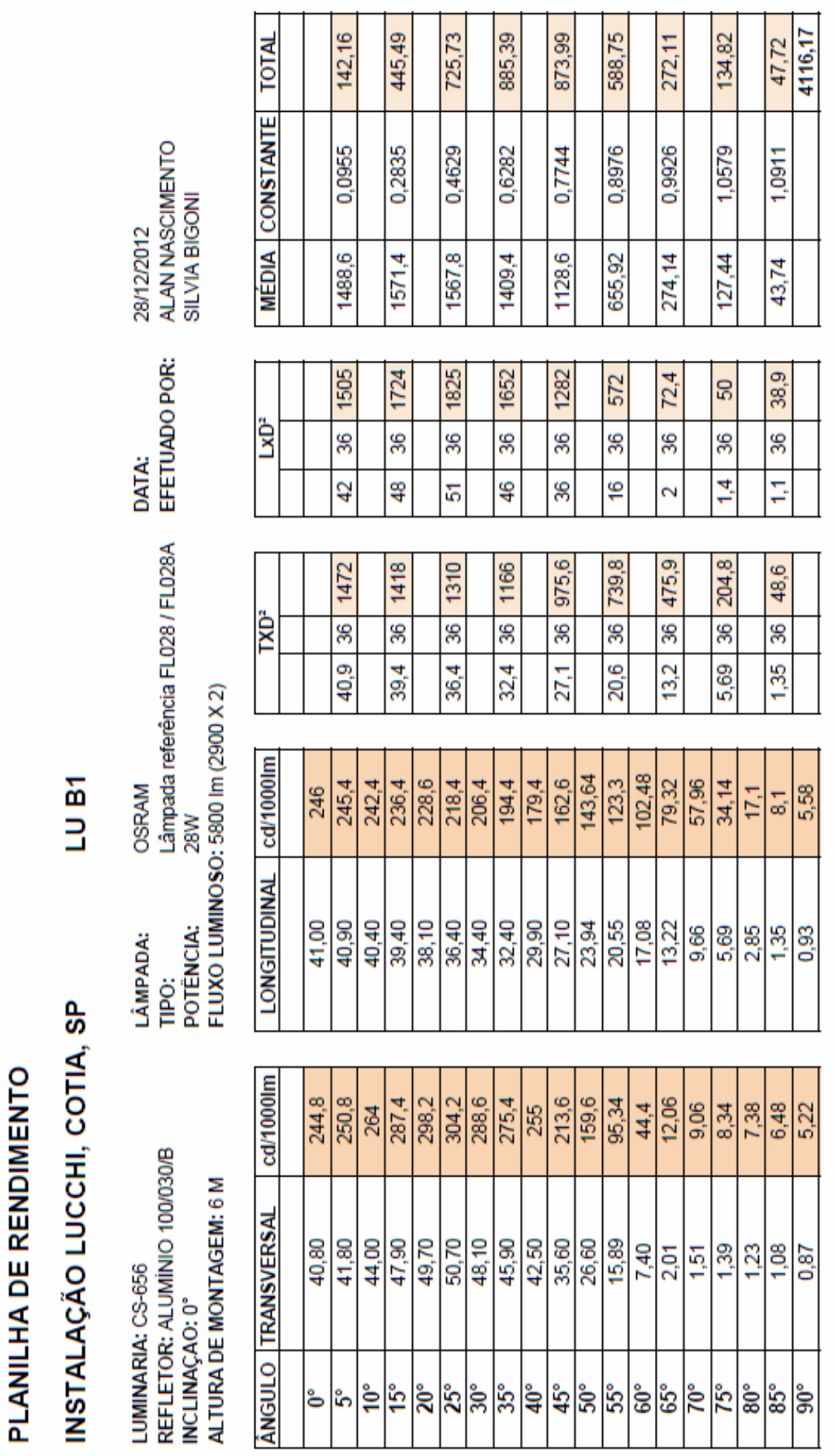

Fonte: a autora, 2013. 


\subsubsection{Ensaio da luminária de ensaio- LU C1 (1.576 horas)}

Tabela 46 - Tabulação da luminária de ensaio - Instalação 2 - LUCCHI Ltda, Cotia, SP - LU C1.

Período da instalação: 1.576 horas
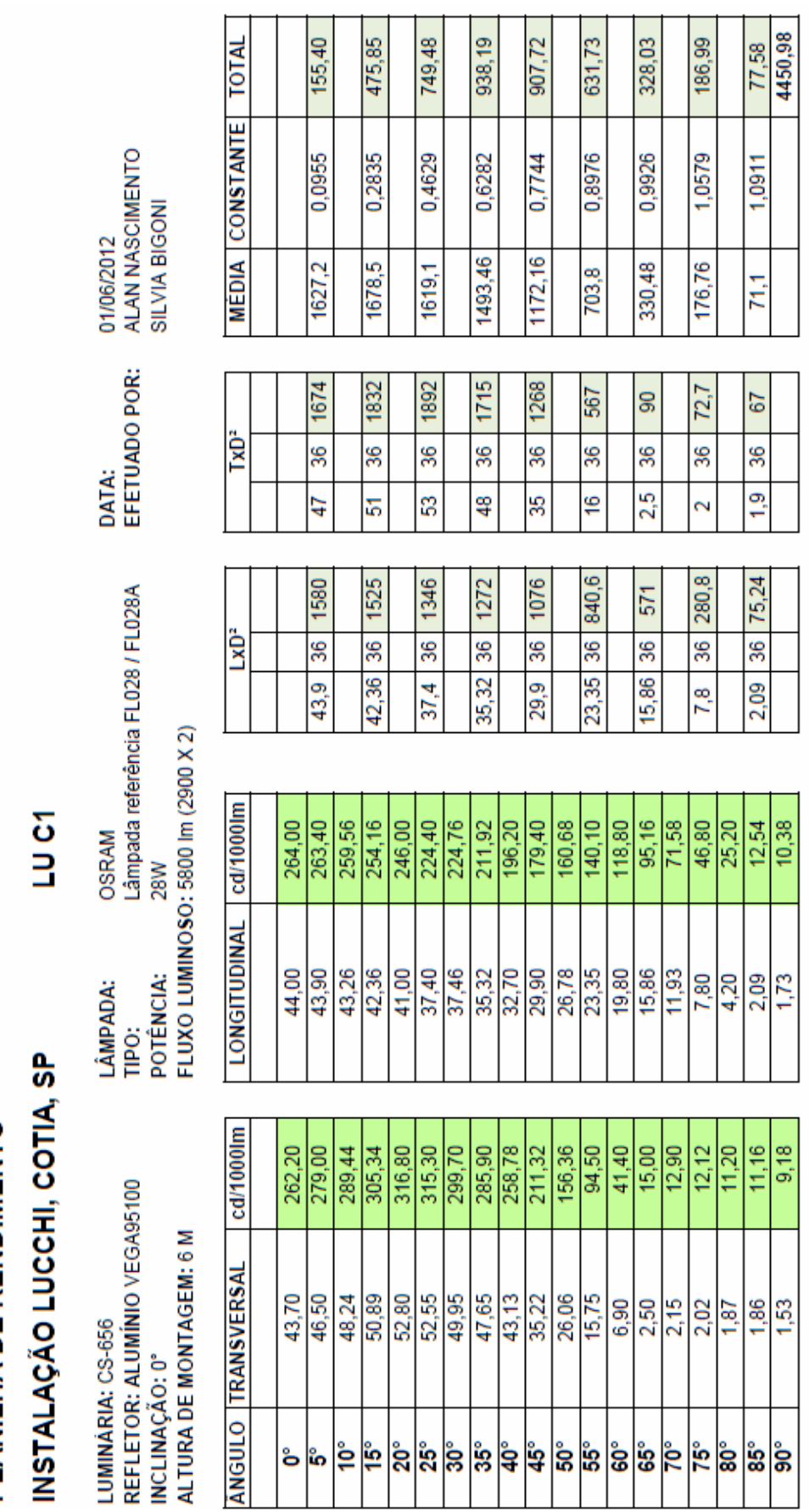

Fonte: a autora, 2013. 


\subsubsection{Ensaio da luminária de ensaio - LU C1 (2.720 horas)}

Tabela 47 - Tabulação da luminária de ensaio - Instalação 2 - LUCCHI Ltda. Cotia, SP - LU C1.

Período da instalação: 2.720 horas.

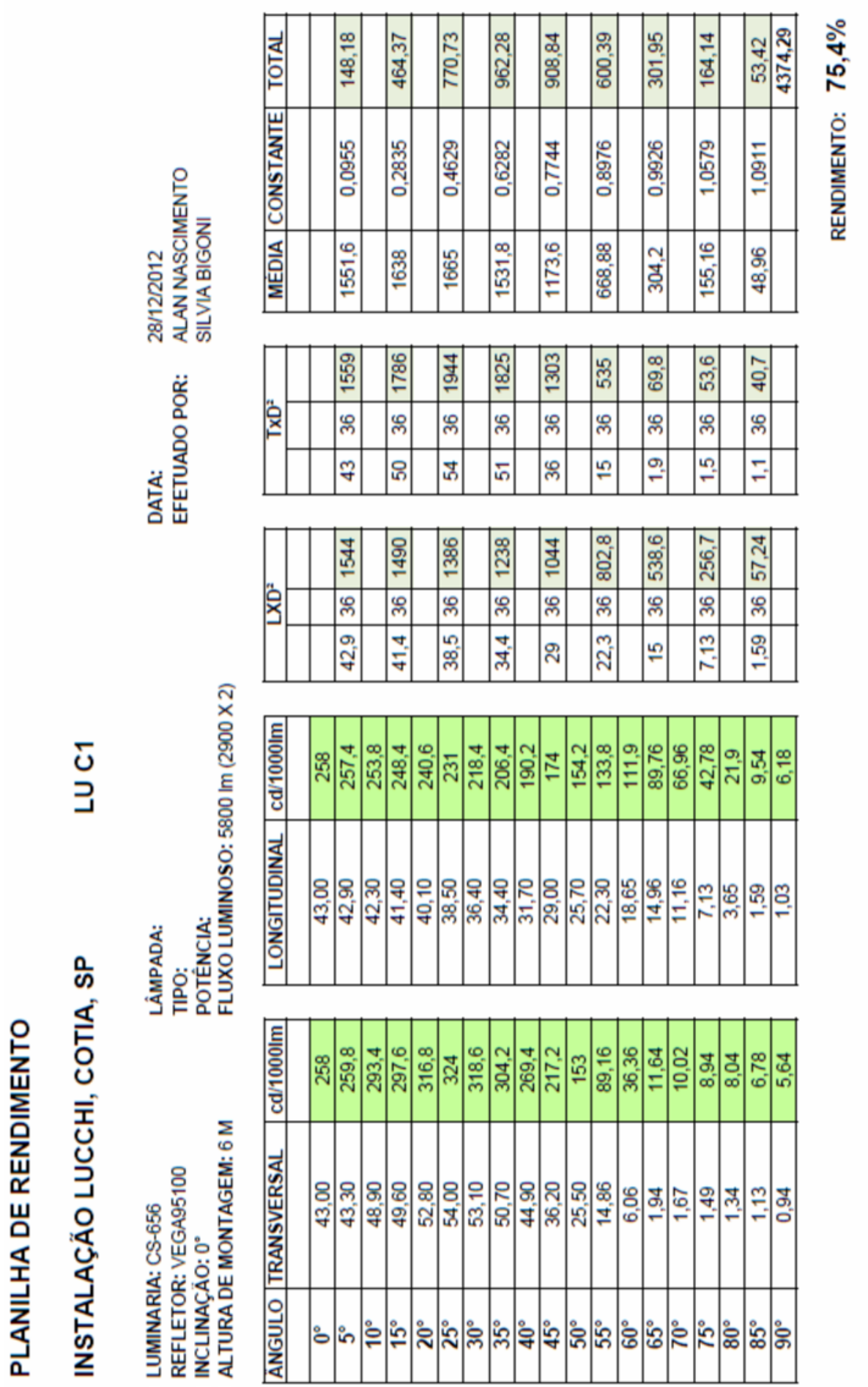

Fonte: a autora, 2013. 
7.5. Resultados dos ensaios das luminárias de campo - Instalação 3Condomínio PORTO de IBIÚNA, Ibiúna, SP. - PO A1, PO B1 e PO C1

\subsubsection{Ensaio da luminária de ensaio - PO A1 (1.648 horas)}

Tabela 48 - Tabulação da luminária de ensaio - Instalação 3 - Condomínio PORTO de IBIÚNA, Ibiúna, SP. - PO A1

Período da instalação: 1.648 horas
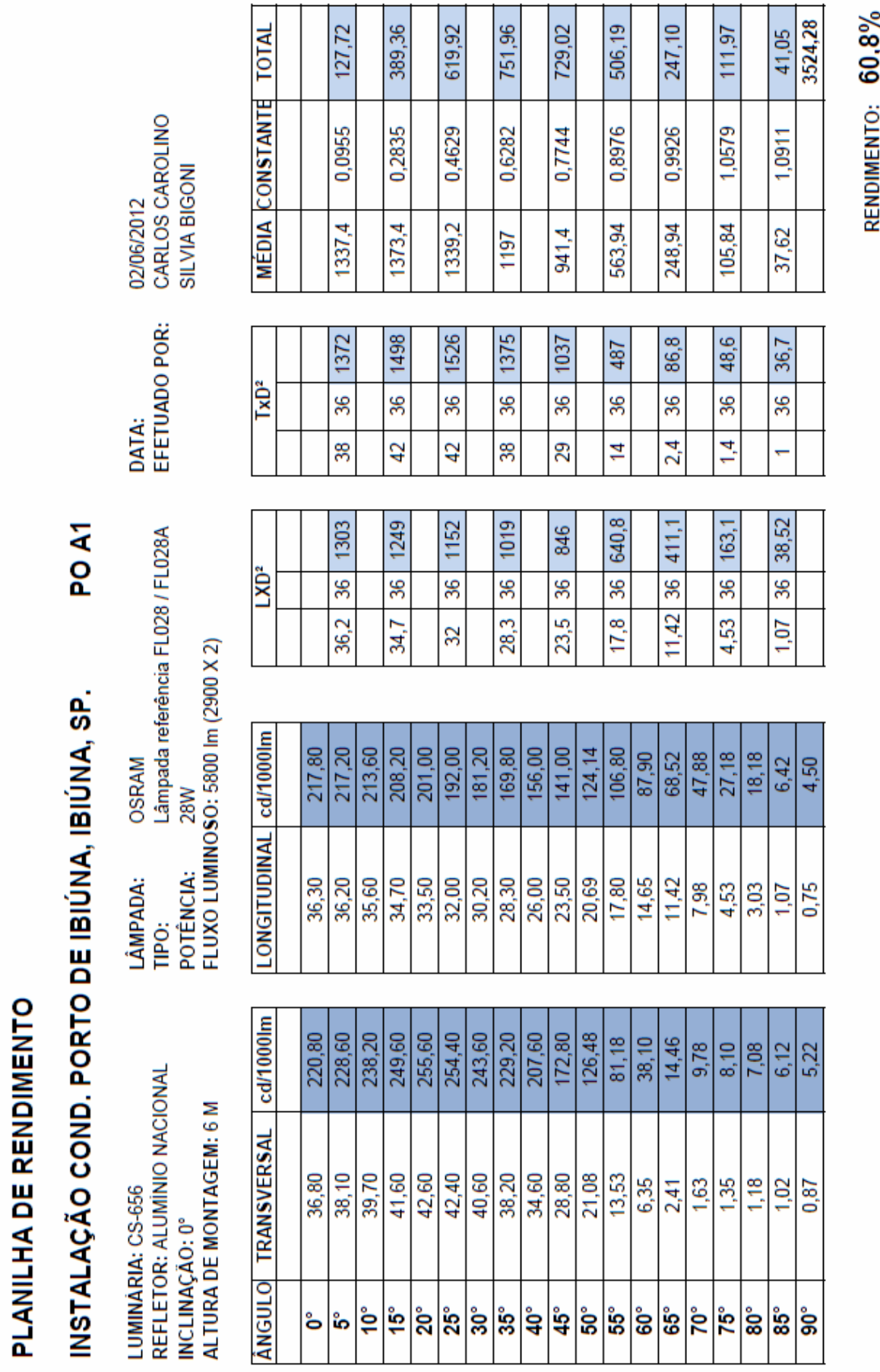

Fonte: a autora, 2013. 


\subsubsection{Ensaio da luminária de ensaio - PO A1 (2.856 horas)}

Tabela 49 - Tabulação da luminária de ensaio - Instalação 3 - Condomínio PORTO de IBIÚNA, Ibiúna, SP. - PO A1

Período da instalação: 2.856 horas

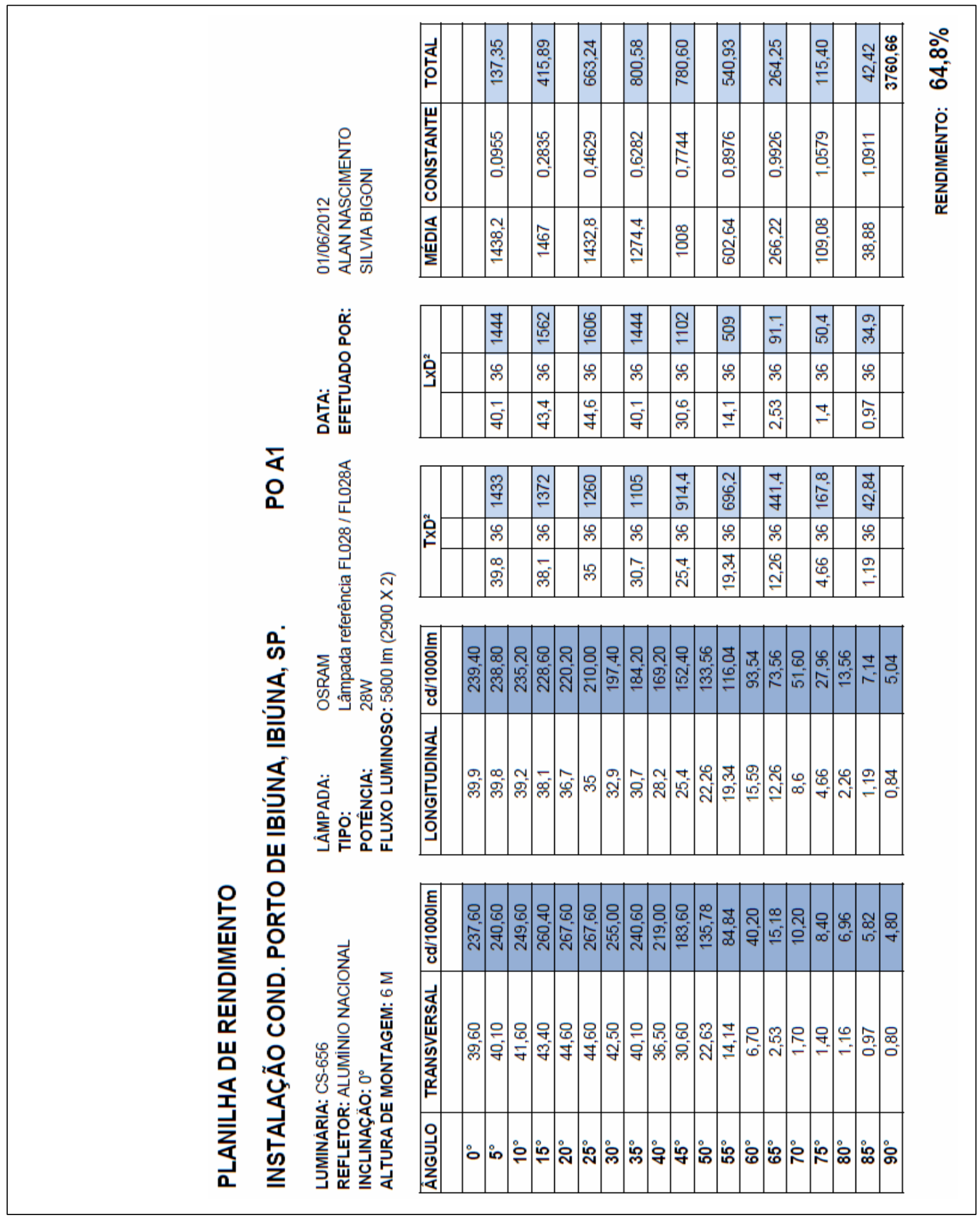

Fonte: a autora, 2013. 


\subsubsection{Ensaio da luminária de ensaio - PO B1 (1.648 horas)}

Tabela 50 - Tabulação da luminária de ensaio - Instalação 3 - Condomínio PORTO de IBIÚNA, Ibiúna, SP. - PO B1

Período da instalação: 1.648 horas
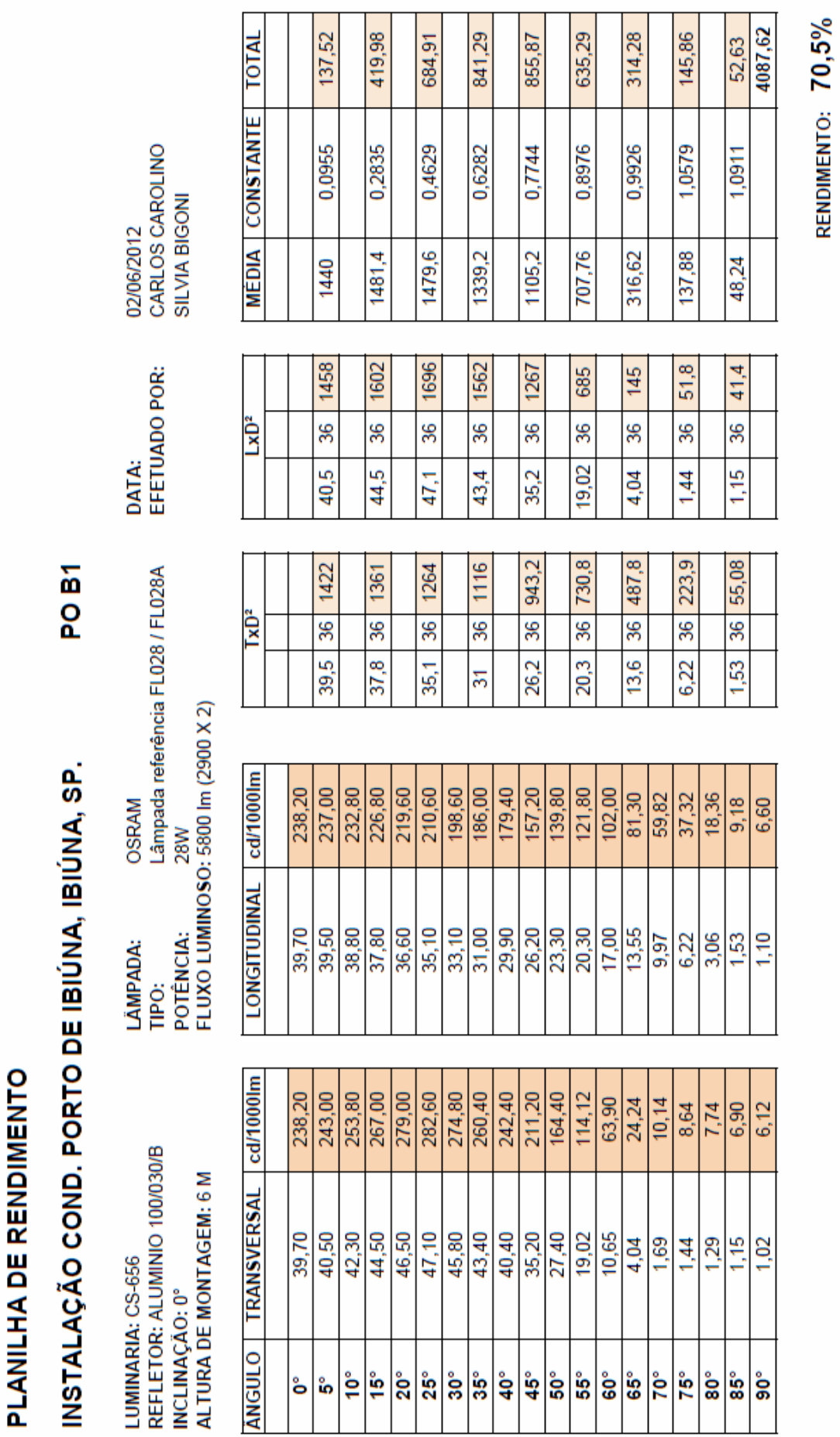

Fonte: a autora, 2013. 


\subsubsection{Ensaio da luminária de ensaio- PO B1 (2.856 horas)}

Tabela 51 - Tabulação da luminária de ensaio - Instalação 3 - Condomínio PORTO de IBIÚNA, Ibiúna, SP. - PO B1

Período da instalação: 2.856 horas

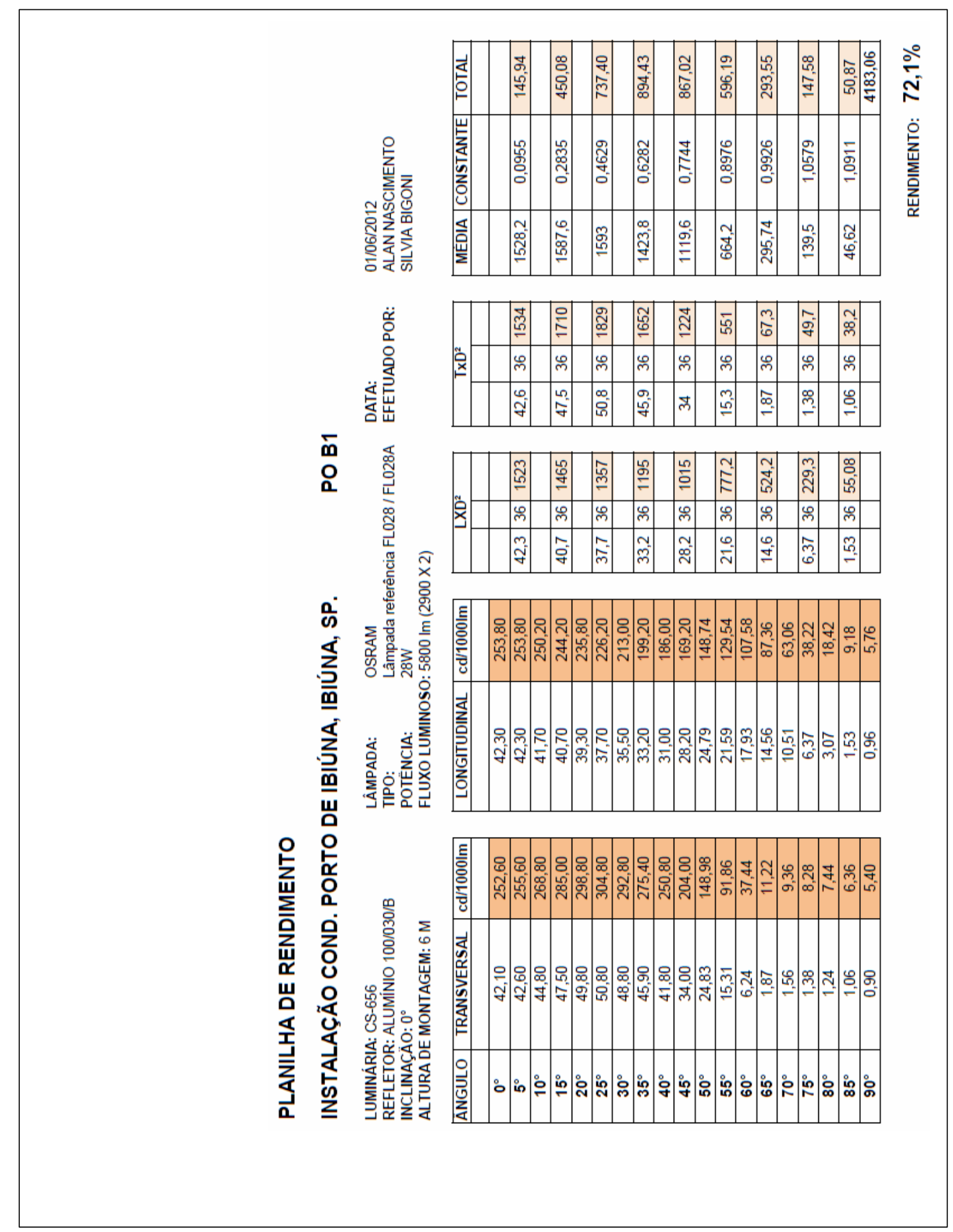

Fonte: a autora, 2013. 


\subsubsection{Ensaio da luminária de ensaio- PO C1 (1.648 horas)}

Tabela 52 - Tabulação da luminária de ensaio - Instalação 3 - Condomínio PORTO de IBIÚNA, Ibiúna, SP. - PO C1

Período da instalação: 1.648 horas

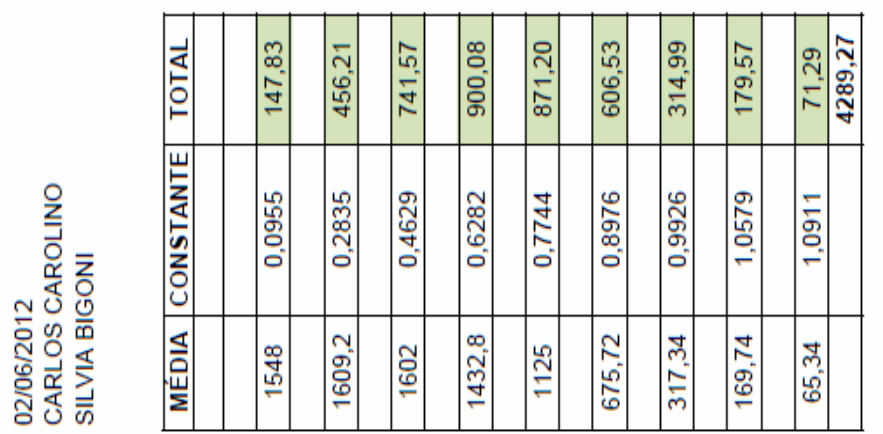

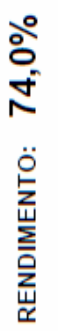

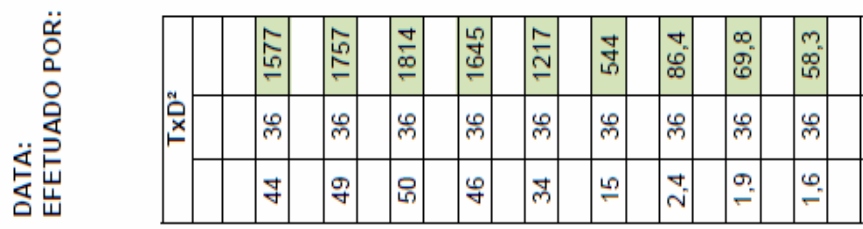

¿̀

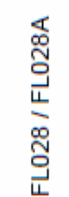

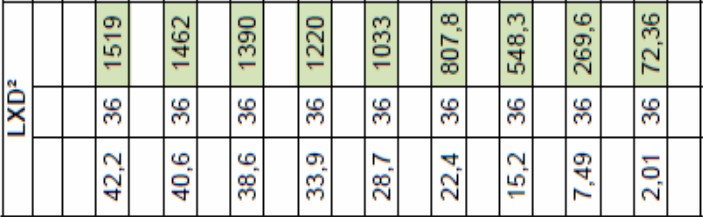

ลิ

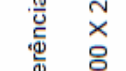

の

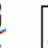

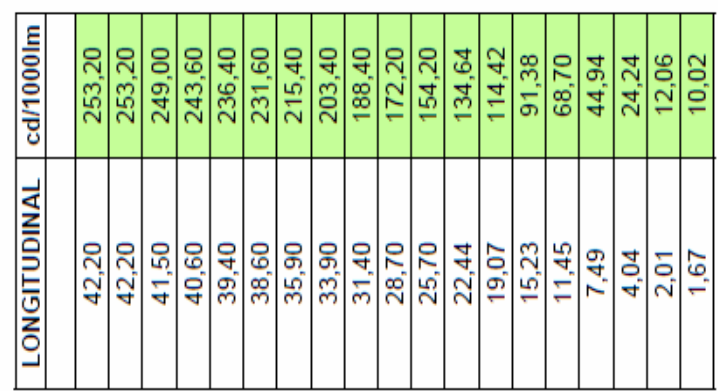

号

品

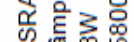

○ ज्त

至

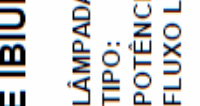

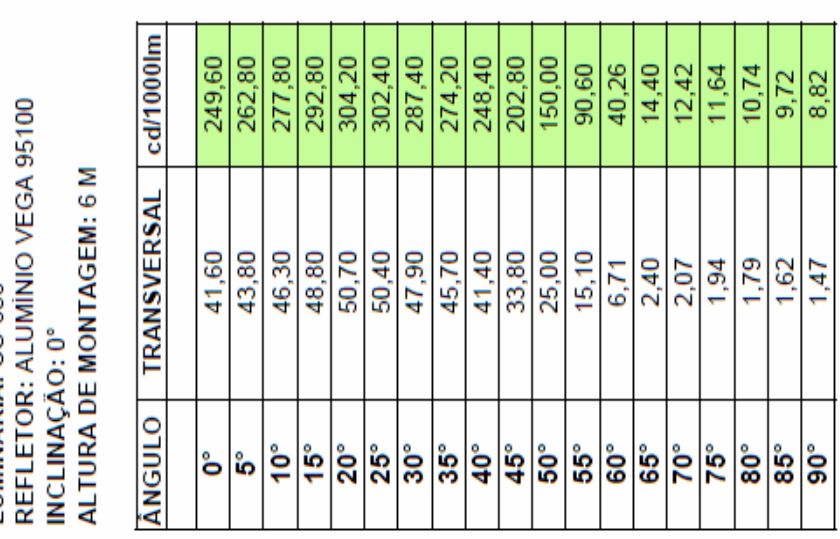

Fonte: a autora, 2013. 


\subsubsection{Ensaio da luminária de - PO C1 (2.856 horas)}

Tabela 53 - Tabulação da luminária de ensaio - Instalação 3 - Condomínio PORTO de IBIÚNA, Ibiúna, SP. - PO C1

Período da instalação: 2.856 horas

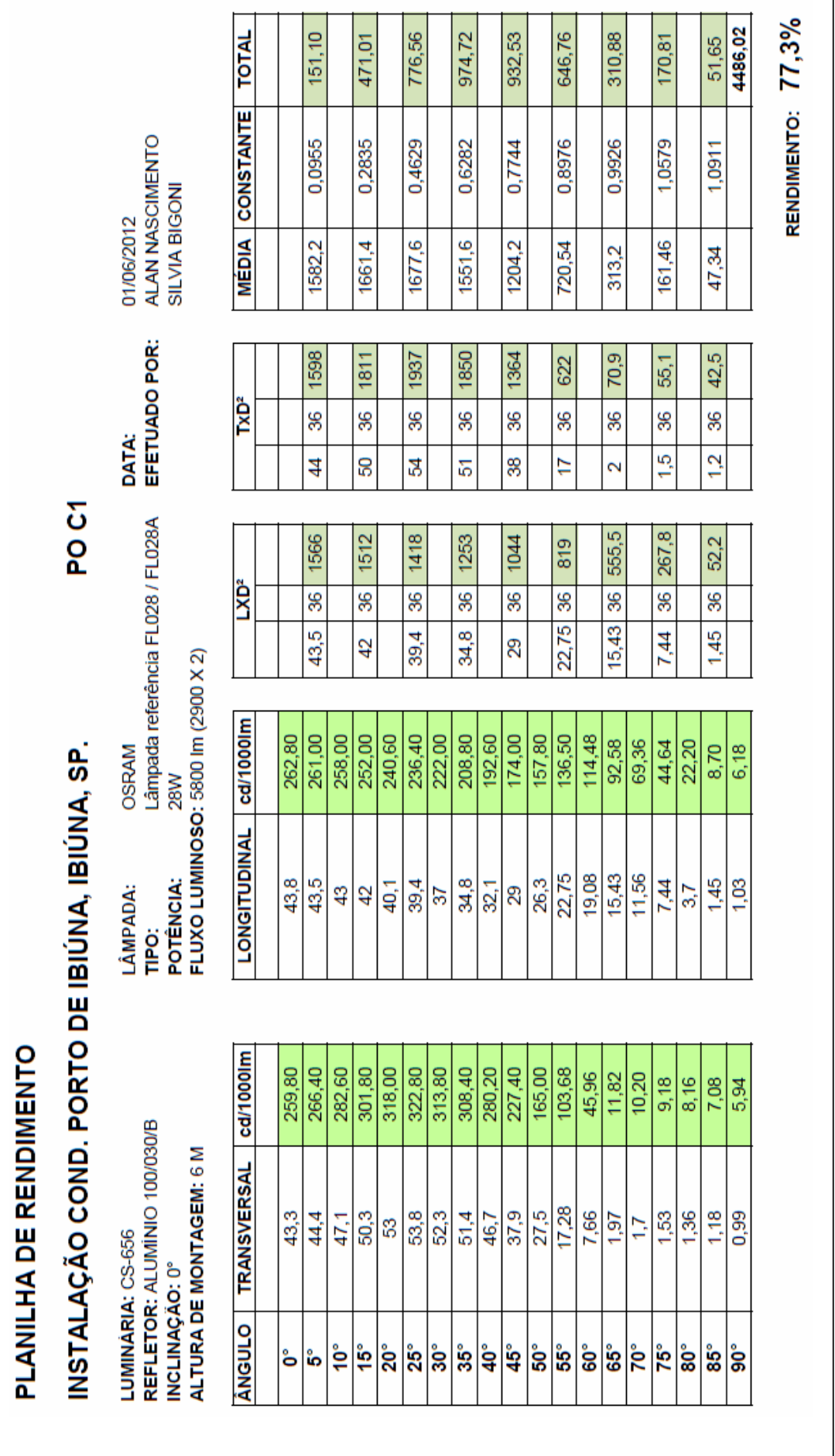

Fonte: a autora, 2013. 
8 APPRESENTACÅ E INARLISE DOS RESULTADOS

Através da metodologia proposta, apresentam-se as variações percentuais verificadas nas perdas luminosas dos conjuntos óticos das luminárias de ensaios em relação aos conjuntos de referências.

Tabela 54 - Redução percentual dos rendimentos das luminárias de campo em relação aos conjuntos óticos de referência.

\begin{tabular}{|c|c|c|c|c|c|c|}
\hline & R A1 & $\begin{array}{l}\text { Redução } \\
(\%)\end{array}$ & R B1 & $\begin{array}{c}\text { Redução } \\
\text { (\%) }\end{array}$ & R C1 & $\begin{array}{c}\text { Redução } \\
(\%)\end{array}$ \\
\hline $\begin{array}{l}\text { Conjunto ótico } \\
\text { de referência }\end{array}$ & $66,70 \%$ & & $74,20 \%$ & & $77,80 \%$ & \\
\hline \multicolumn{7}{|c|}{ Etapa 1 - Período médio em funcionamento ( 8 horas/dia) - 1.578 horas (197 dias) } \\
\hline & FA A1 & & FA B1 & & FA C1 & \\
\hline \multirow[t]{2}{*}{ Instalação 1} & $65,40 \%$ & $1,95 \%$ & $72,30 \%$ & $2,56 \%$ & $77,30 \%$ & $0,64 \%$ \\
\hline & LU A1 & & LU B1 & & LU C1 & \\
\hline \multirow[t]{2}{*}{ Instalação 2} & $63,40 \%$ & $4,95 \%$ & $73,80 \%$ & $0,53 \%$ & $76,70 \%$ & $1,41 \%$ \\
\hline & PO A1 & & PO B1 & & PO C1 & \\
\hline Instalação 3 & $60,80 \%$ & $8,85 \%$ & $70,50 \%$ & $4,99 \%$ & $74,00 \%$ & $4,88 \%$ \\
\hline \multicolumn{7}{|c|}{ Etapa 2 - Período médio em funcionamento ( 8 horas/dia) - 2.730 horas (342 dias) } \\
\hline & FA A1 & & FA B1 & & FA C1 & \\
\hline \multirow[t]{2}{*}{ Instalação 1} & $62,10 \%$ & $6,88 \%$ & $71,80 \%$ & $3,24 \%$ & $74,60 \%$ & $4,11 \%$ \\
\hline & LU A1 & & LU B1 & & LU C1 & \\
\hline \multirow[t]{2}{*}{ Instalação 2} & $62,20 \%$ & $6,74 \%$ & $71,00 \%$ & $4,31 \%$ & $75,40 \%$ & $3,09 \%$ \\
\hline & PO A1 & & PO B1 & & $\mathrm{PO} \mathrm{C} 1$ & \\
\hline Instalação 3 & $64,80 \%$ & $2,85 \%$ & $72,10 \%$ & $2,83 \%$ & $77,30 \%$ & $0,64 \%$ \\
\hline
\end{tabular}

Fonte: a autora, 2013.

Verificaram-se determinantes conclusões com relação à utilização dos alumínios com características reflexivas distintivas, dos quais, mesmo que do ponto de vista visual inicialmente tenham a mesma característica brilhante e especular, os resultados mostram que as luminárias de ensaios FA A1, LU A1 e PO A1 apresentaram situação mais crítica, dentro do período de análise, em relação ao conjunto ótico de referência $R$ A1. Uma possível explicação se deve ao fato de o alumínio não ter o tratamento de anodização 
da superfície e de apresentar fragmentos minúsculos de óxido, o que o torna mais impuro. Além de conter essas impurezas, observou-se que as suas propriedades de reflexão foram variáveis e com um alto nível de embaçamento $^{88}$, ocorrido provavelmente pela sua condição crítica à baixa resistência à corrosão, que dificulta a sua manutenção e limpeza. Como o fator de manutenção é um critério importante deste trabalho, considera-se que possivelmente este alumínio, sendo desprotegido, muito macio e com dureza aproximada de $50 \mathrm{Hv}$, terá a sua superfície seriamente arranhada com um simples esfregar de um tecido ou pano macio, e sua superfície brilhante destruída (ALMECO, 2011).

Analisando o conjunto ótico de referência, identificamos uma reflexão inicial de 66,7\%.

A aparência visual do conjunto ótico de referência $R A 1$, ilustrada na Figura 114, do Anexo I, mostra na superfície ótica uma textura de pequenos veios $^{89}$ orientados possivelmente na direção do bobinamento ${ }^{90}$ da chapa do alumínio. São pequenos arranhões que acabam dispersando mais a luz e fazem a superfície parecer mais nebulosa ${ }^{91}$.

Avaliando-se as três instalações de campo, após um período de uso médio de 2.738 horas, observou-se uma redução de 6,88\% em relação à luminária de ensaio $\mathrm{FA} A 1$, de 6,74 \% em relação à luminária de ensaio LU $\mathrm{A} 1$, e de 2,85 \% em relação à luminária de ensaio PO $\mathrm{A} 1$, com uma média de $5,5 \%$ no rendimento dos modelos e perda de parte de sua propriedade reflexiva, comparativamente com o conjunto de referência $R A 1$, além de uma aparência enevoada mais perceptível, conforme o ilustrado nas Figuras 117 (1.512 horas) e 120 (2.640 horas) da luminária de ensaio FA A1.

Os ensaios das luminárias de ensaios FA B1, LU B1 e PO B1, em relação ao conjunto ótico de referência $\mathrm{R} B 1$, apresentaram uma condição considerada boa, com redução de 3,24\% em relação à luminária de ensaio FA B1, de 4,31 \% de redução em relação à luminária de ensaio LU B1, e 2,83\% de redução em relação à luminária de ensaio $\mathrm{PO} B 1$, com média de

\footnotetext{
${ }^{88}$ Embaçamento - Ato ou efeito de embaçar; embaçadela.

${ }^{89}$ Veio - Faixa longa e estreita, encontrada nas madeiras, pedras e outras superfícies, e que se distingue pela natureza ou pela cor.

${ }^{90}$ Bobinamento - Processo de se enrolar um material flexível, neste caso o alumínio em um cilindro.

${ }^{91}$ Nebulosa - Obscuro, pouco claro, turvo, falta de nitidez.
} 
$3,46 \%$ de perdas luminosas e de rendimento após o mesmo período de depreciação das instalações.

Essa menor perda se deve principalmente ao fato de que o alumínio nomeado de B1 recebeu uma fina camada de recobrimento anódico e efetivamente tem uma maior resistência à corrosão em ambientes úmidos e salinos.

Visualmente não se observaram alterações das superfícies dos alumínios dos modelos ensaiados, conforme o ilustrado nas Figuras 118 (1.512 horas) e 121 (2.640 horas) da luminária de ensaio FA B1.

Os ensaios das luminárias de ensaios FA C1, LU C1 e PO C1, em relação ao conjunto ótico de referência $\mathrm{R} C 1$, apresentaram a melhor condição com a menor perda de luminosidade e depreciação do rendimento, com uma redução de 4,11 \% em relação à luminária de ensaio FA C1, de $3,09 \%$ de redução em relação à luminária de ensaio LU C1, e 0,64 \% de redução em relação à luminária de ensaio PO C1, com uma média de 2,61\% após o mesmo período de funcionamento das instalações.

A menor perda da luminosidade e de rendimento e a melhoria na eficiência foi possível devido ao processo de deposição de filmes finos, através de vaporização do alumínio de alta pureza, o que elevou ainda mais a resistência à corrosão, sem alteração ou perda de refletividade.

Aparentemente, não se observaram alterações das superfícies de alumínios dos modelos ensaiados, exemplificado nas Figuras 119 (1.512 horas) e 122 (2.640 horas) da luminária FA C1.

Foram Identificados desvios nos resultados das medições na Etapa 1, após um período médio de 1.648 horas de funcionamento das luminárias de ensaios PO A1, PO B1 e PO C1, denominadas de instalação 3 - Condomínio PORTO de IBIÚNA, Ibiúna, SP .

Os resultados dessas medições fotométricas foram descartados, visto que apresentaram valores inferiores, divergentes e que não estão de acordo com os demais resultados, conforme apresentado na Tabela 55. 
Tabela 55 - Desvios das medições das luminárias de campo - PO A1, PO B1 e PO C1.

\begin{tabular}{|c|c|c|c|c|c|c|}
\hline & R A1 & \begin{tabular}{|c|} 
Redução \\
$(\%)$
\end{tabular} & R B1 & $\begin{array}{c}\text { Redução } \\
(\%)\end{array}$ & R C1 & \begin{tabular}{|c|} 
Redução \\
$(\%)$
\end{tabular} \\
\hline $\begin{array}{l}\text { Conjunto ótico de } \\
\text { referência }\end{array}$ & $66,70 \%$ & & $74,20 \%$ & & $77,80 \%$ & \\
\hline \multicolumn{7}{|c|}{ Etapa 1 - Período em funcionamento (8 horas/dia) - 1.648 horas (206 dias ) } \\
\hline & PO A1 & & PO B1 & & PO C1 & \\
\hline Instalação 3 & $60,80 \%$ & $8,85 \%$ & $70,50 \%$ & $4,99 \%$ & $74,00 \%$ & $4,88 \%$ \\
\hline \multicolumn{7}{|c|}{ Etapa 2 - Período em funcionamento (8 horas/dia) - 2.856 horas (357 dias) } \\
\hline & PO A1 & & PO B1 & & PO C1 & \\
\hline Instalação 3 & $64,80 \%$ & $2,85 \%$ & $72,10 \%$ & $2,83 \%$ & $77,30 \%$ & $0,64 \%$ \\
\hline
\end{tabular}

Fonte: a autora, 2013.

Uma possível explicação pode ser a não verificação da tensão de alimentação, visto que as medições destas luminárias foram feitas separadamente, no dia 02/06/2012, diferentemente das luminárias de ensaios FA A1, FA B1, FA CI, LU A1, LU B1 e LU C1, que foram ensaiadas no dia 01/06/2012, com a alimentação elétrica estabilizada e controlada.

Avaliando os três conjuntos óticos de referência, observou-se que as diferenças de rendimentos são determinantes, visto que o conjunto ótico de R C1 gera 14,26\% a mais de luz do que o conjunto ótico R A1, pelo mesmo consumo energético, e o conjunto ótico R B1 gera 10,11 \% a mais de luz, em relação ao conjunto ótico $R$ A1, conforme a Tabela 56.

Tabela 56- Diferença entre os rendimentos dos modelos de referência ensaiados.

\begin{tabular}{|l|c|c|c|}
\hline Modelos & $\begin{array}{c}\text { Diferença (\%) } \\
\text { RA1 - R C1 }\end{array}$ & $\begin{array}{c}\text { Diferença (\%) } \\
\text { R A1 - R B1 }\end{array}$ & $\begin{array}{c}\text { Diferença (\%) } \\
\text { RB1 - R C1 }\end{array}$ \\
\hline $\begin{array}{l}\text { Conjunto ótico de } \\
\text { referência }\end{array}$ & $14,26 \%$ & $10,11 \%$ & $4,63 \%$ \\
\hline
\end{tabular}

Fonte: a autora, 2013. 


\section{(2) CONSIDERACO̊ES FINAIS, CONCLUSO็ES E GONTRUDURCO็ES DA DISSERTAGAOE EUGESTÅ PARAA FUTUROS TRARALLOS}

\subsection{Considerações finais}

Este trabalho teve por objetivo apresentar uma análise quanto ao uso de distintos tipos de alumínios empregados na fabricação dos conjuntos óticos das luminárias comerciais.

O segmento de iluminação passou por muitas transformações no decorrer dos anos e matérias-primas poucos utilizadas no passado expandiram o seu uso por conta das novas necessidades do mercado e do consumidor, que se utiliza cada vez mais de materiais recicláveis.

O alumínio passou a ser cada vez mais exigido na fabricação de luminárias em virtude da qualidade, eficiência e durabilidade. No entanto, para garantir essas propriedades por muitos anos é cada vez mais indispensável o uso do tratamento de superfície por meio de anodização.

Esse mesmo tratamento já é empregado há muitos anos em outros materiais, como esquadrias, portões etc., de forma a evitar a oxidação que ocorre frequentemente quando instalados em regiões litorâneas.

Além disto, considerando que a periodicidade da manutenção dos sistemas de iluminação deve adequar-se a cada tipo de instalação, o fator de depreciação utilizado pelo projetista de iluminação deverá conciliar as informações de projeto e as condições de manutenção, em razão da complexidade do sistema, de sua importância e das influências externas do local.

A prática do mercado está no uso do fator de depreciação $(F d)$ em 0,80 , mas para condições mais criticas a prática de um fator de depreciação de até 0,70 será o mais indicado. Essa condição já está sendo recomendada pela Norma NBR ISO 8995-1 (aprovada e em fase de publicação) e pela CIE 97:2005. 
Do ponto de vista energético, quanto menor o rendimento de uma luminária, maior o desperdício de energia elétrica, mas quanto maior a refletância do alumínio, maior será o rendimento do sistema.

Se for analisado o caso de uma instalação nova comercial, pública ou de serviço, em que estaria em discussão a escolha sobre qual das opções a ser adotada será a melhor, para a fabricação de uma luminária eficiente o sistema com o modelo de alumínio C1 será o mais adequado, observando-se que através de uma solução e tecnologia que aparentemente possa ser considerada mais onerosa, é extremamente viável a médio e longo prazo, com a garantia da iluminância desejada, o melhor conforto ambiental, a menor perda luminosa e, principalmente, pelo menor custo energético.

\subsection{Conclusões}

Verificou-se que há uma real perda progressiva das intensidades luminosas e dos rendimentos das luminárias de ensaios FA A1, FA B1, FA C1, LU A1, LU b1, LU C1, PO A1, PO B1 e PO C1 em relação aos conjuntos óticos de referência $R A 1, R B 1$ e $R$ C1.

As perdas das intensidades luminosas e de iluminâncias atendem aos fatores de depreciação praticados no mercado, sendo que esses níveis de iluminação são os recomendados para cada tarefa e fornecidos como iluminâncias de manutenção, que dependem das características de manutenção da lâmpada, da luminária (parte do objeto de ensaio deste trabalho), do ambiente e do programa de manutenção. O projeto de iluminação deve ser desenvolvido com o fator de manutenção total calculado para o equipamento de iluminação selecionado, para o tipo de ambiente e para o cronograma de manutenção especificado.

Os resultados demonstraram que nos ambientes onde o sal está presente na atmosfera, a durabilidade das superfícies dos alumínios B1 e C1 tiveram a menor depreciação, e a superfície A1 a que mais teve a sua superfície danificada. Isto se deve, possivelmente, após um breve período de exposição ao sal e também à umidade. Essa condição, conhecida como patina atmosférica, é um branqueamento da camada de óxido durante a 
exposição atmosférica e visualizada no ensaio de corrosão por exposição à atmosfera úmida saturada, executado no Departamento de Corrosão do IPT (2005), conforme mostra a Tabela 57 do anexo II.

\subsection{Contribuições da dissertação}

É de suma importância ampliar a discussão sobre a real necessidade do uso de alumínios sem anodização na fabricação de luminárias comerciais e para o desenvolvimento dos sistemas óticos, já que não há como administrar a falta de conhecimento do mercado consumidor.

Acrescenta-se a isso a criação de novos elementos e informações para levar a indústria de luminárias a um novo patamar de qualidade.

Permeou ainda o trabalho a necessidade de difundir as tecnologias inovadoras de tratamento de superfície dos alumínios, expandindo o conhecimento de suas características e durabilidade, de forma a garantir a qualidade das instalações e atender aos apelos sustentáveis, conceito altamente em foco em novos projetos, em razão de ser um material totalmente reciclável, com $100 \%$ de reaproveitamento e de fácil transformação.

\subsection{Sugestão para futuros trabalhos}

Dando continuidade a esta pesquisa, é proposto o desenvolvimento de outras atividades, na busca do aprimoramento e correções no método sugerido. Para isso torna-se relevante a necessidade de:

- Elevar o tempo dos ensaios de campo por um período superior a 5.000 horas, objetivando perdas luminosas mais realistas;

- $\quad$ Ensaios em laboratórios acreditados pelo INMETRO;

- $\quad$ Ensaios de aceleração de corrosão por exposição à atmosfera úmida saturada dos modelos, fixando um período de exposição;

- Ensaios dos índices de refletância em diferentes posições angulares entre a fonte de emissão e o sensor de fotodetecção, para a 
obtenção da quantidade de luz incidida na superfície de referência dos conjuntos óticos, conforme a intensidade luminosa da luz especularmente refletida e a razão entre a intensidade da luz emitida;

- Ensaios de exposição à névoa salina, onde se induz um processo de corrosão acelerada por um período de 240 horas, conforme o sugerido na ASTM B 117:2003 - Standard Practice for Operating Salt Spray (Fog) Apparatus;

- $\quad$ Ensaios da determinação da espessura da camada anódica dos alumínios pelo método microscópico, conforme Norma ISO 1463:1998;

- Simulações com outros tipos de conjuntos óticos, como refletor e aleta branca, refletor de alumínio e aleta branca, refletor de alumínio sem aleta e refletor branco sem aleta, por exemplo;

- Simulações em ambientes com outros fatores de influência sobre as perdas luminosas, como por exemplo, com sistemas de condicionamento de ar;

- Simulações computacionais comparando os sistemas, nas quais se considere diferentes tipos de edificações, em função de características arquitetônicas e atividade comercial desenvolvida. 


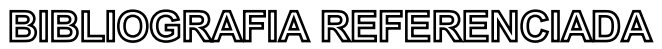

ALANOD. Catálogos de alumínios. ALANOD Aluminium-Veredlung GmbH\&Co, Ennepetal, 2003.

ALMECO. Catálogos de alumínios. ALMECO Group S.p.A.

ARAUJO, Guilherme Augusto Marques. Avaliação dos ganhos de eficiência energética em iluminação adotando a regulamentação de etiquetagem em edificações. Dissertação apresentada à Escola Politécnica da Universidade de São Paulo, 2009.

ASHRAE, AMERICAN SOCIETY OF HEATING, REFRIGERATING AND AIRCONDITIONING ENGINEERS. Energy Standard for Buildings Except LowRise Residential Buildings. ASHRAE Standard 90.1 -1989. American Society of Heating, Refrigerating and Air-Conditioning Engineers, Inc. Atlanta, 2007.

ASHRAE, AMERICAN SOCIETY OF HEATING, REFRIGERATING AND AIRCONDITIONING ENGINEERS. Proposed Addendum by to ANSI/ASHRAE/IESNA Standard 90.1-2007, Energy Standard for Buildings Except Low-Rise Residential Buildings. Second Public Review Draft (January 2010).

ASHRAE Standard 90.1 - 2010. American Society of Heating, Refrigerating and Air-Conditioning Engineers, Inc. Atlanta, 2010.

ASSOCIAÇÃO BRASILEIRA DA INDÚSTRIA DE ILUMINAÇÃO. Levantamento do estágio tecnológico do setor de iluminação. São Paulo: Centro São Paulo Design, CSPD, 2005, 86p.

ASSOCIAÇÃO BRASILEIRA DE ALUMÍNIO. Guia técnico do alumínio Tratamento de Superfície. $1^{\circ}$ Edição, 1996, p.11/15/39/175

ASSOCIAÇÃO BRASILEIRA DE ALUMÍNIO. Fundamentos e Aplicações do Alumínio, 2007, p.28.

ASSOCIAÇÃO BRASILEIRA DE ALUMÍNIO. Guia de Laminação do Alumínio, 2004, p.19/35/39. 
ASSOCIAÇÃO BRASILEIRA DE CORROSÃO. 2011. Disponível em: http://www.abraco.org.br/site/. Acesso em 04/out/2011.

ASSOCIAÇÃO BRASILEIRA DE NORMAS TÉCNICAS. Norma NBR 5461/1992 Iluminação (Terminologia). Rio de Janeiro.1992, p.33/35/41.

ASSOCIAÇÃO BRASILEIRA DE NORMAS TÉCNICAS. Norma NBR ISSO 8995 Iluminação de ambientes de trabalho. (Norma aprovada em fase de publicação pela $A B N T)$.

ASSOCIAÇÃO BRASILEIRA DE NORMAS TÉCNICAS. Norma NBR 14155:2010 Alumínio e suas ligas - Tratamento de superfície - Camada de anodização dura- determinação da microdureza. Rio de Janeiro, 2010, p.3.

ASSOCIAÇÃO BRASILEIRA DE NORMAS TÉCNICAS Norma NBR 5382:1985 Verificação de iluminância de interiores. Rio de Janeiro, 1985, p.2.

ASSOCIAÇÃO BRASILEIRA DE NORMAS TÉCNICAS Norma NBR 5413:1992 Iluminância de interiores. Rio de Janeiro, 1992, p.2-3.

ASSOCIAÇÃO BRASILEIRA DE NORMAS TÉCNICAS Norma NBR 5410:1997 Instalações Elétricas de Baixa Tensão. Rio de Janeiro, 1997, p.102.

ASSOCIAÇÃO BRASILEIRA DE NORMAS TÉCNICAS. Norma ISO 7583:2010 Anodização do alumínio e suas ligas - vocabulário. Rio de Janeiro, 2010, p. 2/4/5/6/11/13.

ASSOCIAÇÃO BRASILEIRA DE NORMAS TÉCNICAS. Norma NBR 8095:1983 Material Metálico revestido e não-revestido corrosão por exposição á atmosfera úmida saturada- Método de ensaio. Rio de Janeiro, 1983, p.8.

ASSOCIAÇÃO BRASILEIRA DE TRATAMENTO DE SUPERFICIE. 2011. Disponível em: http://www.abts.org.br/biblioteca/artigos-e-utilitarios. Acesso em 24/out/2011.

ASTM E1651-94:1999. Standard Test Method for Total Luminous

Reflectance Factor by Use of 30/t Integrating-Sphere Geometry, p.9.

ASTM B-117. Method of Salt Spray (Fog), p.5. 
COMPANHIA BRASILEIRA DE ALUMÍNIO. Processos e Produtos. Disponível em: <http://www.cia-brasileira-aluminio.com.br/pt/processos.php.>. Acesso em 12/out/ 2011.

COSTA, José Gilberto Correa da. Iluminação Econômica - Cálculo e Avaliação, Editora da PUC-RS, Porto Alegre, 2006, p.184/189/204/295.

DICIONÁRIO ON LINE DE PORTUGUÊS. Disponível em http://www.dicio.com.br/Acesso em 20/nov/2011; 29/mar/2012; 20/fev/2013.

DIN 67 530:1982. Reflectometer as a means for gloss assessment of plane surfaces of paint coatings and plastics, p.6/ 8.

EGAN, David M. Concepts in Architectural Lighting, Editora McGraw-Hill Publishing Company, 1983.p.42/121/207.

GHISI, Enedir. Desenvolvimento de uma metodologia para retrofit em sistemas de iluminação: estudo de caso na Universidade Federal de Santa Catarina. Dissertação submetida à na Universidade Federal de Santa Catarina, Florianópolis, 1997.

GHISI, Enedir (1); LAMBERTS, Roberto (2). Influência das Características Reflexivas da Luminária e da Refletância das Paredes na Potência Instalada em Sistema de Iluminação. Trabalho apresentado no VII Encontro Nacional de Tecnologia do Ambiente Construído - Qualidade no Processo Construtivo- Núcleo de Pesquisa em Construção, Universidade Federal de Santa Catarina, Florianópolis, SC,1998.

IES. Illuminating Engineering Society of North America. IES Lighting Handbook References And Applications, 8th Edition, New York, IESNA, 1995.

INSTITUTO NACIONAL DE METROLOGIA, QUALIDADE E TECNOLOGIA. Unidade de base do sistema internacional. 2011. Disponível em: <http://www.inmetro.gov.br/consumidor/unidLegaisMed.asp?iacao>. Acesso em 08/nov/2011.

INSTITUTO DE GEOCIÊNCIA DA UNIVERSIDADE DE BRASILIA. Glossário Geológico Ilustrado. Disponível em:< http://vsites.unb.br/ig/glossario/index.html. Acesso em 08/nov/ 2011. 
ITALTECNO DO BRASIL. Noções Básicas sobre processos de anodização do Alumínio e suas Ligas. Disponível em:

<http://italtecno.com.br/artigos_tecnicos/Edição_11.pdf>. Acesso em 08/nov/2011.

LIGHTING ACADEMY. Disponível em

http://www.lightingacademy.org/encyclopedia/htm/ita/illuminazione/illuminazione. Acesso em 15/out/2011.

OSRAM, do Brasil - Catalogo Geral - 2012.p.5.03

OSRAM, do Brasil- Informação técnica QUICKTRONIC PROFESSIONAL T5 Reator para lâmpadas fluorescentes T5. Edição: Maio, 2006.

PHILIPS, Manual de Iluminação- Centro de Projetos e Engenharia de lluminação da Philips Lighting Divison em Eindhoven, Holanda, 1986. Pag.67/72/74.

LAMBERTS, Roberto; DUTRA, Luciano; PEREIRA, Fernando O.R. Eficiência Energética na Arquitetura. 1.ed, São Paulo, Editora PW

Editores,1997.p.74/82/171.

MOREIRA, Vinícius de Araújo. Iluminação Elétrica, Ed. Edgar Blucher Ltda, 1999, p.25/31/46/97.

PIMENTA, G.S. Corrosão. Disponível em:<http://www.iope.com.br/3i_corrosao.htm>. Acesso em 08/nov/2011.

PINTO, Rinaldo Caldeira- Goniofotômetro e determinação de fluxo luminoso, aula 5- Curso de fotometria On-line LUMIERE/IEE, 2004.

PINTO, Rinaldo Caldeira- Fotometria de luminárias para interiores, aula 6- Curso de fotometria On-line LUMIERE/IEE, 2004.

PINTO, Rinaldo Caldeira- Curva de luminância e fotometrias de luminárias para interiores, aula 7- Curso de fotometria On-line LUMIERE/IEE, 2004. 
PROCEL Edifica - RAC-C- Regulamento de Avaliação da Conformidade do Nível de Eficiência Energética de Edifícios Comerciais, de Serviços e Públicos, 2011.

PROCEL Edifica - RTQ-C - Regulamento Técnico da Qualidade do Nível de Eficiência Energética de Edifícios Comerciais, de Serviços e Públicos - Anexo da portaria INMETRO no 53, 2009, p.27-29/31.

RAMANATHAN, L. V., Corrosão e seu Controle. Editora Lemus, 1990.

VIANNA, S.Nelson; GONÇALVES, Joana Carla. Iluminação e Arquitetura, 3.ed.,São Paulo, Editora Geros s/c Ltda,2007, p.73/106/190/201. 
BUBLIOGRAAPA CONSULTIADA

ALANOD. Catálogos de alumínios. ALANOD , Aluminium-Veredlung GmbH\&Co, Ennepetal, 2003.

ALMECO. Catálogos de alumínios. ALMECO Group S.p.A,2011.

ARAUJO, Guilherme Augusto Marques. Avaliação dos ganhos de eficiência energética em iluminação adotando a regulamentação de etiquetagem em edificações. Dissertação apresentada à Escola Politécnica da Universidade de São Paulo, 2009.

ASHRAE, AMERICAN SOCIETY OF HEATING, REFRIGERATING AND AIRCONDITIONING ENGINEERS. Energy Standard for Buildings Except LowRise Residential Buildings. ASHRAE Standard 90.1 -1989. American Society of Heating, Refrigerating and Air-Conditioning Engineers, Inc. Atlanta, 2007.

ASHRAE, AMERICAN SOCIETY OF HEATING, REFRIGERATING AND AIRCONDITIONING ENGINEERS. Proposed Addendum by to ANSI/ASHRAE/IESNA Standard 90.1-2007, Energy Standard for Buildings Except Low-Rise Residential Buildings. Second Public Review Draft (January 2010). ASHRAE Standard 90.1 - 2010. American Society of Heating, Refrigerating and Air-Conditioning Engineers, Inc. Atlanta, 2010.

ASOCIACIÓN ARGENTINA DE LUMINOTECNICA. Luz, Vision, Comunicación, Buenos Aires, 2001, Tomo 1 e 2.

ASSOCIAÇÃO BRASILEIRA DA INDÚSTRIA DE ILUMINAÇÃO. Levantamento do estágio tecnológico do setor de iluminação. São Paulo: Centro São Paulo Design, CSPD, 2005, p.86.

ASSOCIAÇÃO BRASILEIRA DE ALUMÍNIO. Guia técnico do alumínio Tratamento de Superfície. $1^{\circ}$ Edição, 1996, p.11/15/39/175.

ASSOCIAÇÃO BRASILEIRA DE ALUMÍNIO. Fundamentos e Aplicações do Alumínio, 2007, p.28. 
2004. p.19/35/39.

ASSOCIAÇÃO BRASILEIRA DE CORROSÃO. 2011. Disponível em: http://www.abraco.org.br/site/. Acesso em 04/out/2011.

ASSOCIAÇÃO BRASILEIRA DE NORMAS TÉCNICAS. Norma NBR 5461/1992 Iluminação (Terminologia). Rio de Janeiro.1992. p.33/35/41.

ASSOCIAÇÃO BRASILEIRA DE NORMAS TÉCNICAS. Norma NBR 14155:2010 Alumínio e suas ligas - Tratamento de superfície - Camada de anodização dura- determinação da microdureza. Rio de Janeiro, 2010, p.3.

ASSOCIAÇÃO BRASILEIRA DE NORMAS TÉCNICAS Norma NBR 5382:1985 Verificação de iluminância de interiores. Rio de Janeiro, 1985. p.2.

ASSOCIAÇÃO BRASILEIRA DE NORMAS TÉCNICAS Norma NBR 5413:1992 Iluminância de interiores. Rio de Janeiro, 1992, p.2-3.

ASSOCIAÇÃO BRASILEIRA DE NORMAS TÉCNICAS Norma NBR 5410:1997 Instalações Elétricas de Baixa Tensão. Rio de Janeiro, 1997, p.102.

ASSOCIAÇÃO BRASILEIRA DE NORMAS TÉCNICAS Norma NBR IEC 60598-1Luminárias - Parte 1: Requisitos gerais e ensaios. Rio de Janeiro: ABNT, 1999c. p.24/25/66.

ASSOCIAÇÃO BRASILEIRA DE NORMAS TÉCNICAS Norma NBR IEC 60598-21- Luminárias - Parte 2: Requisitos particulares - Capítulo 1: Luminárias fixas para uso em iluminação geral. Rio de Janeiro: ABNT, 1999d.

ASSOCIAÇÃO BRASILEIRA DE NORMAS TÉCNICAS Norma NBR 13299 Luminária para lâmpada tubular fluorescente - Ensaios. Rio de Janeiro: ABNT, 1995.

ASSOCIAÇÃO BRASILEIRA DE NORMAS TÉCNICAS. Norma ISO 7583:2010 Anodização do alumínio e suas ligas - vocabulário. Rio de Janeiro, 2010, p. 2/46/11/13. 
ASSOCIAÇÃO BRASILEIRA DE NORMAS TÉCNICAS. Norma NBR 8095:1983 Material Metálico revestido e não-revestido corrosão por exposição á atmosfera úmida saturada- Método de ensaio. Rio de Janeiro, 1983, p.8.

ASSOCIAÇÃO BRASILEIRA DE TRATAMENTO DE SUPERFICIE. 2011. Disponível em: http://www.abts.org.br/biblioteca/artigos-e-utilitarios. Acesso em 24/out/2011.

ASTM E1651-94:1999. Standard Test Method for Total Luminous

Reflectance Factor by Use of 30/t Integrating-Sphere Geometry, p. 9.

ASTM B-117. Method of Salt Spray (Fog), p. 5.

BRANDSTON, Howard M. Aprender a ver : a essência do design da lluminação, tradução Paulo Sergio Scarazzato.1.ed.São Paulo, Editora De Maio, 2010, p.129.

CAVALCANTE, Rodrigo de Castro Dantas. Simulação energética para análise da arquitetura de edifícios de escritório além da comprovação de conformidade com códigos de desempenho. Dissertação para Faculdade de Arquitetura e Urbanismo da Universidade de São Paulo, São Paulo, 2010.

COMPANHIA BRASILEIRA DE ALUMÍNIO. Processos e Produtos. Disponível em: <http://www.cia-brasileira-aluminio.com.br/pt/processos.php.>. Acesso em 12/out/ 2011.

COSTA, José Gilberto Correa da. Iluminação Econômica - Cálculo e Avaliação, Editora da Puc Rs, Porto Alegre, 2006, p.184/189/204/295.

DICIONÁRIO ON LINE DE PORTUGUÊS. Disponível em http://www.dicio.com.br/Acesso em 20/nov/2011; 29/mar/2012; 20/fev2/2013.

DIN 67 530:1982. Reflectometer as a means for gloss assessment of plane surfaces of paint coatings and plastics, p.6/ 8 .

FEIJÓ, Maria Alice de Souza. Leis, normas e certificações de qualidade referentes à iluminação natural em edifícios comerciais. Dissertação para Faculdade de Arquitetura e Urbanismo da Universidade de São Paulo. São Paulo, 2009.

Fundação Vanzolini. Referencial Técnico de certificação. Edifícios do setor de serviços - Processo AQUA. Escritórios - Edifícios escolares, outubro 2007. 
IES. Illuminating Engineering Society Of North America. IES Lighting Handbook References And Applications, 8th Edition, New York, IESNA, 1995.

INSTITUTO NACIONAL DE METROLOGIA, QUALIDADE E TECNOLOGIA. Unidade de base do sistema internacional. 2011. Disponível em: <http://www.inmetro.gov.br/consumidor/unidLegaisMed.asp?iacao>. Acesso em 08/nov/2011.

INSTITUTO DE GEOCIÊNCIA DA UNIVERSIDADE DE BRASILIA. Glossário Geológico Ilustrado. Disponível em:< http://vsites.unb.br/ig/glossario/index.html. Acesso em 08/nov/ 2011.

ISO 8995:2002 / CIE S 008/E-2001. Lighting of indoor work places .

ITALTECNO DO BRASIL. Noções Básicas sobre processos de anodização do Alumínio e suas Ligas. Disponível em:

<http://italtecno.com.br/artigos_tecnicos/Edição_11.pdf>. Acesso em 08/nov/2011.

IWASHITA, Juliana. Eficiência Energética em Sistemas de Iluminação de Interiores: Analise de Luminárias Comerciais. Dissertação apresentada à Escola Politécnica da Universidade de São Paulo, 2004.

JAGLBAUER, Vivien. Contribuição à Melhora das Condições Ambientais de Trabalho Através do aprimoramento da lluminação em Galpões e Pátios Cobertos na Indústria Mineral. Dissertação apresentada à Escola Politécnica da Universidade de São Paulo, 2007.

LIGHTING ACADEMY. Disponível em http://www.lightingacademy.org/encyclopedia/htm/ita/illuminazione/illuminazione. Acesso em 15/out/2011.

PHILIPS, Manual de Iluminação- Centro de Projetos e Engenharia de Iluminação da Philips Lighting Divison em Eindhoven, Holanda, 1986, p.67/72/74.

LAMBERTS, Roberto, DUTRA, Luciano, PEREIRA, Fernando O.R. Eficiência Energética na Arquitetura. 1.ed, São Paulo, Editora PW Editores,1997.p.74/82/171. 
MOREIRA, Vinícius de Araújo. Iluminação Elétrica, Ed. Edgar Blucher Ltda, 1999. p.25/31/46/97.

PIMENTA, G.S. Corrosão. Disponível

em:<http://www.iope.com.br/3i_corrosao.htm>. Acesso em 08/nov/2011.

PINTO, Rinaldo Caldeira- Goniofotômetro e determinação de fluxo luminoso, aula 5- Curso de fotometria On-line LUMIERE/IEE, 2004.

PINTO, Rinaldo Caldeira- Fotometria de luminárias para interiores, aula 6- Curso de fotometria On-line LUMIERE/IEE, 2004.

PINTO, Rinaldo Caldeira- Curva de luminância e fotometrias de luminárias para interiores, aula 7- Curso de fotometria On-line LUMIERE/IEE, 2004.

PROCEL Edifica - RTQ-C - Regulamento Técnico da Qualidade do Nível de Eficiência Energética de Edifícios Comerciais, de Serviços e Públicos - Anexo da portaria INMETRO no 53, 2009, p.27-29/31.

RAMANATHAN, L. V., Corrosão e seu Controle. Editora Lemus, 1990.

VALENTE, Josie Pingret. Certificações na construção civil: comparativo entre LEED e HQE. Projeto de graduação do Curso de Engenharia Civil da Escola Politécnica da Universidade Federal do Rio de Janeiro. Rio de Janeiro, 2009.

VIANNA, S.Nelson, GONÇALVES, Joana Carla. Iluminação e Arquitetura, Ed.Geros s/c Ltda,2007, p.73/106/190/201. 
ANEXOS

ANEXO I - REGISTRO FOTOGRARECO DAS ETAPAS DOS ENSAIOS EMM LABORATORRO

Equipe de apoio: Eng. Alan Nascimentpo, Eng. Carlos Carolino, Arqt. Nelson Solano, Sr. Aguinaldo Reis (fotometrista) e Arqt. Silvia Bigoni.

Figuras 105 e 106 - Registro fotográfico dos preparativos para os ensaios dos conjuntos óticos de referência - R A1, R B1 e R C1. Data: 26/08/2011.
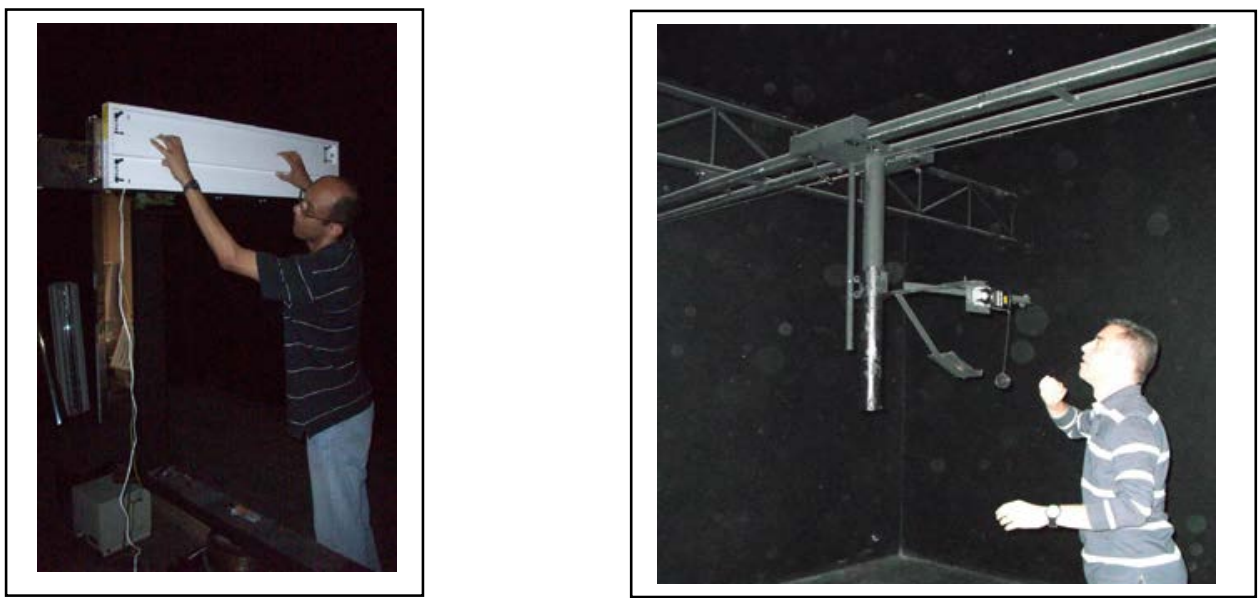

Fonte: Arqt. Silvia Bigoni, Eng. Alan Nascimento e Arqt Nelson Solano, 2011.

Figuras 107 e 108 - Registro fotográfico dos preparativos para os ensaios dos conjuntos óticos de referência - R A1, R B1 e R C1. Data: 26/08/2011
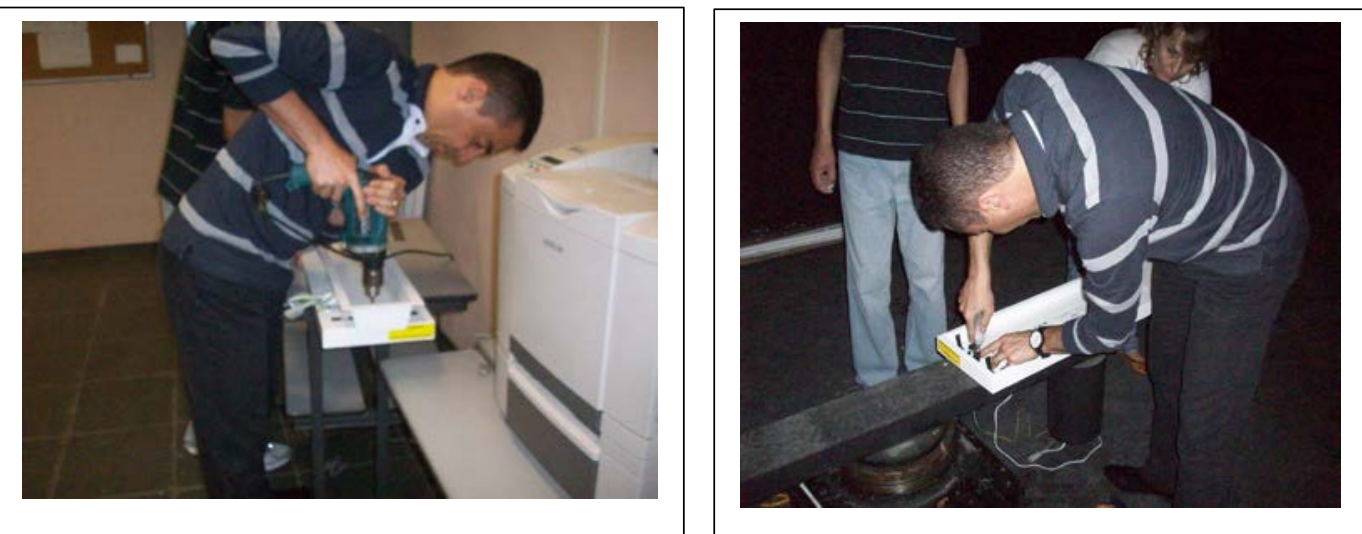

Fonte: Arqt. Silvia Bigoni, Eng. Alan Nascimento e Arqt. Nelson Solano, 2011. 
Figuras 109 e 110 - Registro fotográfico dos preparativos para os ensaios dos conjuntos óticos de referência - R A1, R B1 e R C1. Data: 26/08/2011.
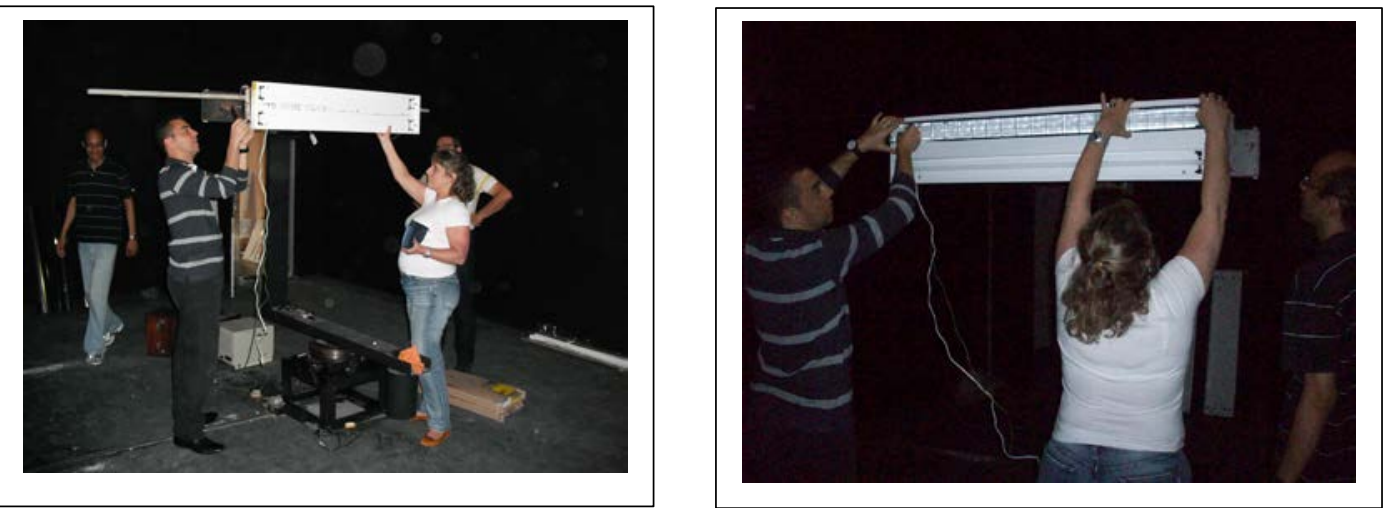

Fonte: Arqt. Silvia Bigoni, Eng. Alan Nascimento e Arqt. Nelson Solano, 2011.

Figuras 111, 112 e 113 - Identificação das luminárias de campo, FA B1, LU C1 e PO A1. Data: 28/12/2012.
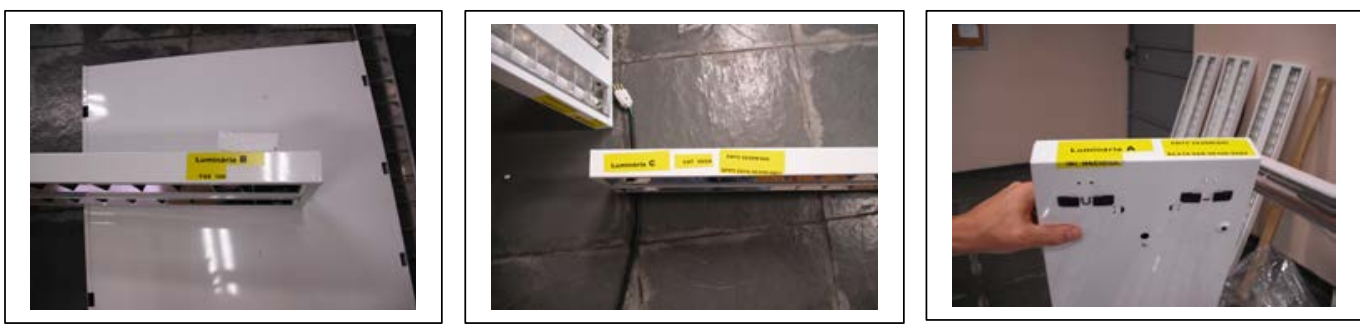

Fonte: Arqt. Silvia Bigoni e Eng. Alan Nascimento, 2012.

Figuras 114, 115 e 116 - Registro fotográfico dos conjuntos óticos de referência $R$ A1, R B1 e R C1.Data: 28/12/2012.

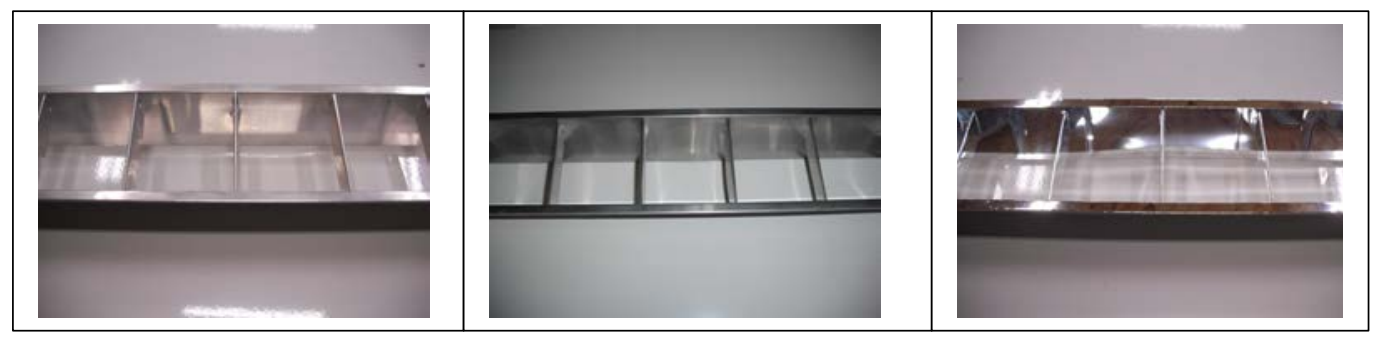

Fonte: Arqt. Silvia Bigoni e Eng. Alan Nascimento, 2012. 
Figura 117,118 e 119 - Registro fotográfico das luminárias de campo - FA A1, FA B1 e FA C1- Condições dos alumínios após periodo de 1.512 horas de funcionamento.

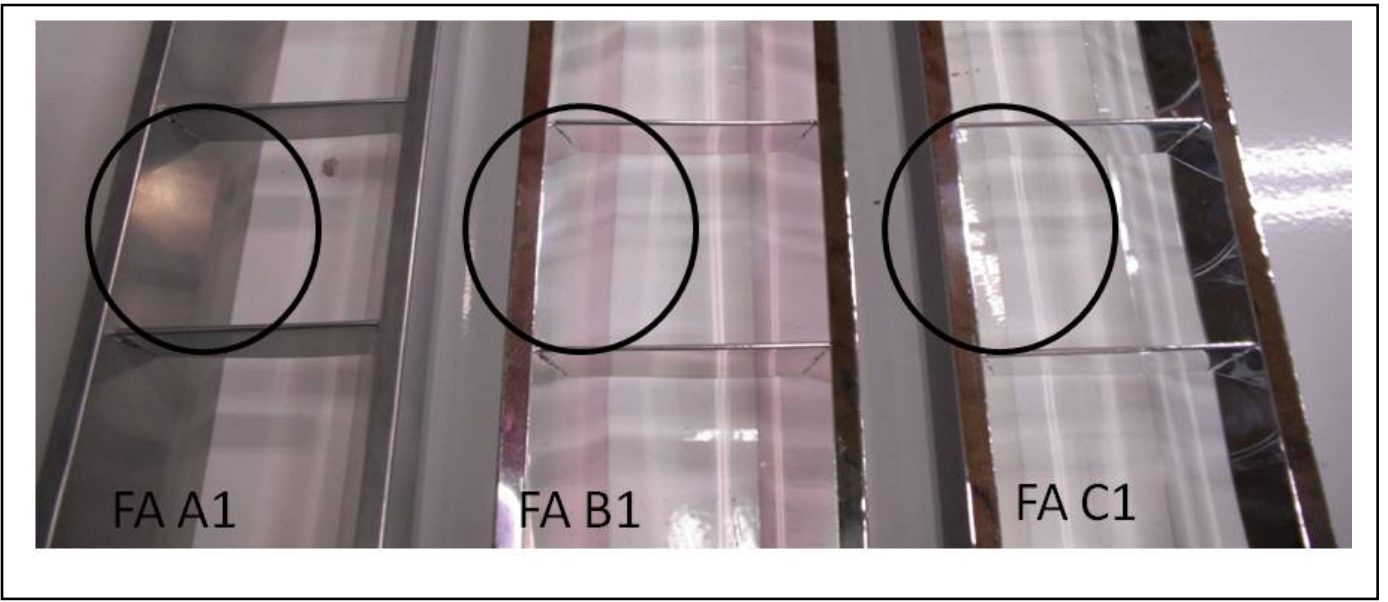

Fonte: Arqt. Silvia Bigoni, 2013.

Figuras 120, 121 e 122- Registro fotográfico das luminárias de campo - FA A1, FA B1 e FA C1 - Condições dos alumínios após periodo de 2.640 horas de funcionamento.

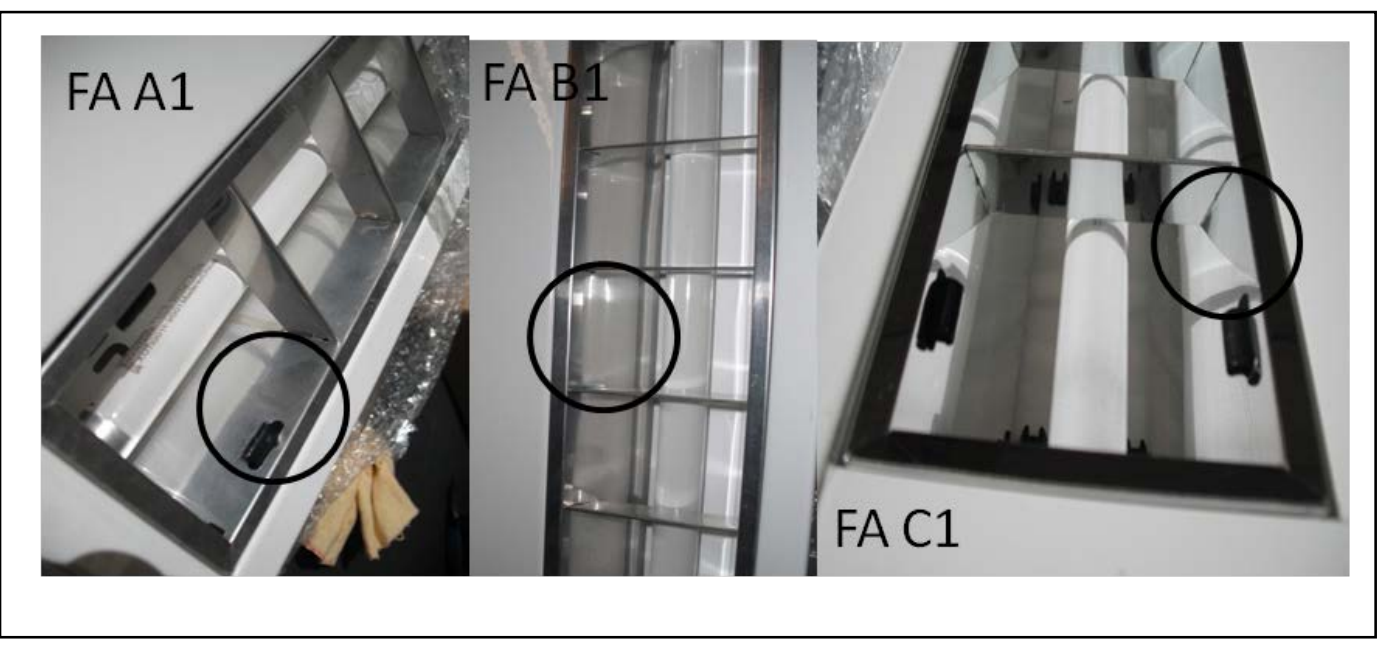


ANEXXO II - CONTRIBUUCROA DE ENSAIOS JA EXXECUTADOS

Natureza do ensaio: Ensaio acelerado de corrosão por exposição à atmosfera úmida saturada e fixado pelo prazo de $240 \mathrm{~h}$. A análise do material é visual e foi executado no IPT em 28/01/2005.

Cliente Solicitante: Lucchi Ltda.

Responsável pelo acompanhamento: Silvia Bigoni

Tabela 57 - Ensaios de câmara úmida executados no IPT

\begin{tabular}{|c|c|c|c|}
\hline & NACIONAL & ALMECO 100/030/B & $\begin{array}{c}\text { ALMECO VEGA } \\
95100\end{array}$ \\
\hline Acabamento & Especular & Especular & Especular \\
\hline 24 horas & $\begin{array}{l}\text { Aparecimento de } \\
\text { manchas brancas e } \\
\text { escuras em cerca de } \\
70 \% \text { da área ensaiada }\end{array}$ & Nenhuma alteração & $\begin{array}{c}\text { Material não } \\
\text { ensaiado }\end{array}$ \\
\hline 72 horas & $\begin{array}{l}\text { perda total de brilho e } \\
\text { manchas escuras com } \\
\text { escorrimento dos } \\
\text { produtos formados }\end{array}$ & Perda de brilho & $\begin{array}{c}\text { Material não } \\
\text { ensaiado }\end{array}$ \\
\hline 192 horas & $\begin{array}{l}\text { produtos escuros } \\
\text { cobrindo cerca de } 70 \% \\
\text { da área ensaiada }\end{array}$ & $\begin{array}{l}\text { Nenhuma alteração } \\
\text { em relação à situação } \\
\text { anterior }\end{array}$ & $\begin{array}{l}\text { Material não } \\
\text { ensaiado }\end{array}$ \\
\hline 240 horas & $\begin{array}{l}\text { nenhum alteração em } \\
\text { relação à situação } \\
\text { anterior }\end{array}$ & $\begin{array}{l}\text { Nenhuma alteração } \\
\text { em relação à situação } \\
\text { anterior }\end{array}$ & $\begin{array}{c}\text { Material não } \\
\text { ensaiado }\end{array}$ \\
\hline
\end{tabular}

Fonte: LUCCHI, IPT, 2005. 
Natureza do ensaio: Ensaio de determinação de refletância após período de corrosão.

Fixado prazos de ensaios de corrosão: 100h, 200h, 300h e 400h.

Ensaios executados no IPT pelo Laboratório de Equipamentos Elétricos e Ópticos em 2005.

Material analisado: Alumínio Nacional e alumínio 100/030/B

Cliente Solicitante: Lucchi Itda

Responsável pelo acompanhamento: Silvia Bigoni

Figura 123 - Ensaio de determinação do índice de refletância - Alumínio Nacional

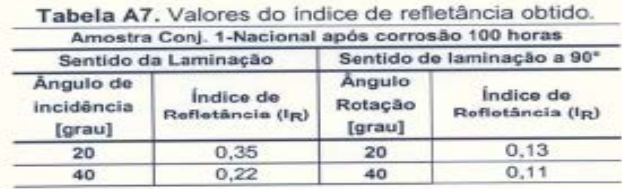

Tabela A8. Valores do indice de refletância obtido.

\begin{tabular}{|c|c|c|c|}
\hline \multicolumn{4}{|c|}{ sao 200 horas } \\
\hline $\begin{array}{c}\text { Ángulo de } \\
\text { incidência } \\
\text { [grau] }\end{array}$ & $\begin{array}{l}\text { Indice de } \\
\text { Refietancia (iR) }\end{array}$ & $\begin{array}{c}\text { Ángulo } \\
\text { Rotaçăo } \\
\text { [grau] }\end{array}$ & $\begin{array}{l}\text { Indice de } \\
\text { Refletância (I/R) }\end{array}$ \\
\hline 2 & & 20 & \\
\hline 40 & 0,06 & 40 & 0.05 \\
\hline
\end{tabular}

Tabela A9. Valures do indice de reflotância obtido.

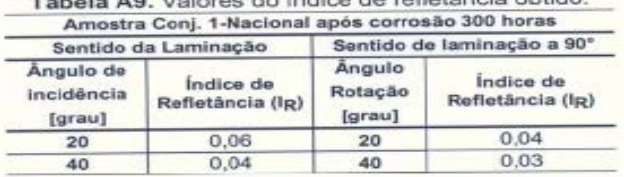

Tabela A10. Valores do indice de refletância obtico

\begin{tabular}{|c|c|c|c|}
\hline \multicolumn{4}{|c|}{ Amostra Conj. 1-Nacional após corrosào 400 horas } \\
\hline Sentido & Laminaçāo & Sentido c & laminaçāo a $90^{*}$ \\
\hline $\begin{array}{l}\text { Angulo de } \\
\text { incidência } \\
\text { [grau] }\end{array}$ & $\begin{array}{c}\text { Indice de } \\
\text { Refletância (IR) }\end{array}$ & $\begin{array}{l}\text { Angulo } \\
\text { Rotaçào } \\
\text { [arau] }\end{array}$ & $\begin{array}{l}\text { Indice de } \\
\text { Refletăncia }\left(\mathrm{I}_{\mathrm{R}}\right)\end{array}$ \\
\hline 20 & o, & 20 & 0,03 \\
\hline 40 & 0.03 & 40 & 0,03 \\
\hline
\end{tabular}

Fonte: LUCCHI, 2005. 
Figura 124 - Ensaio de determinação do índice de refletância - Alumínio

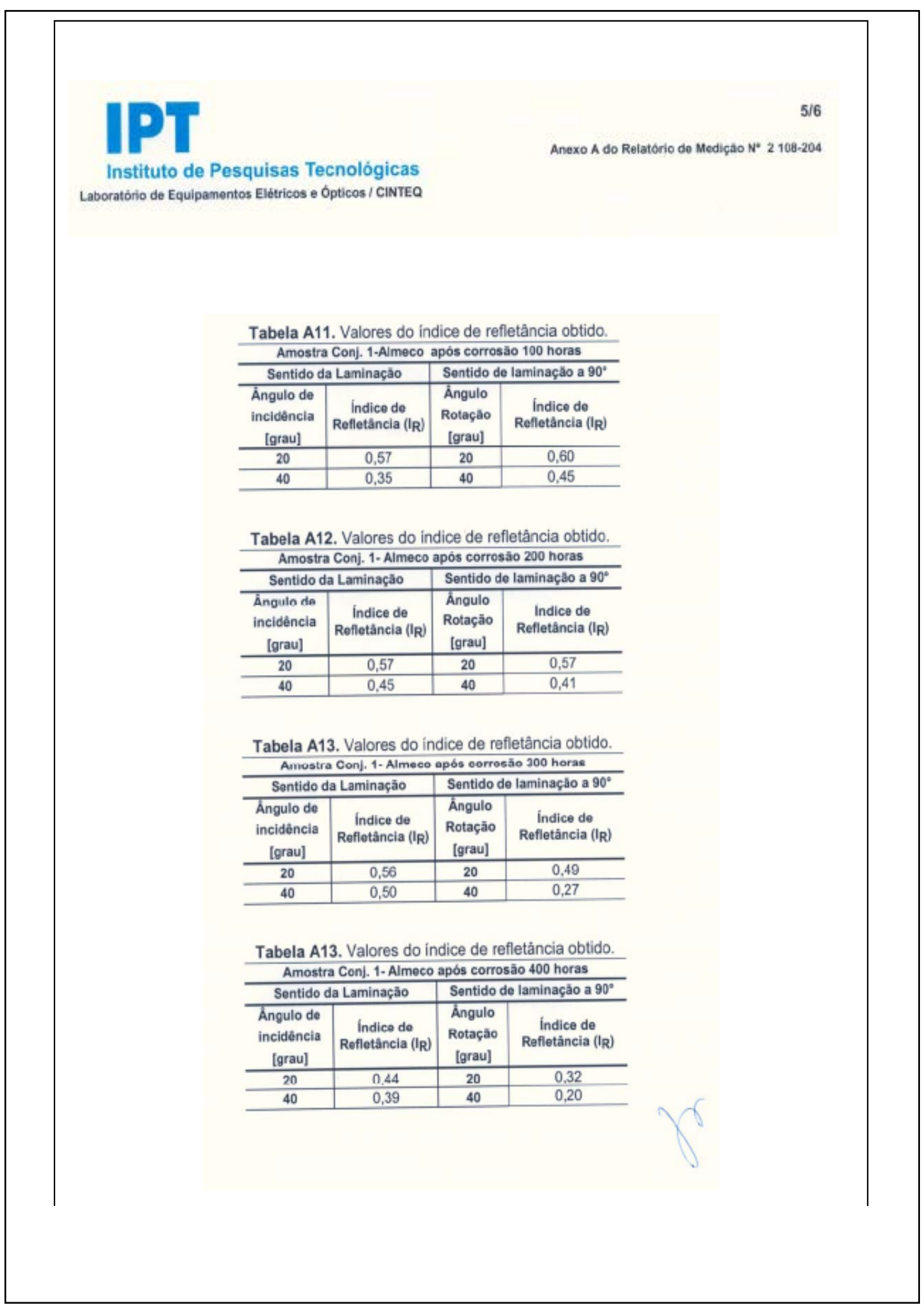

Fonte: LUCCHI, 2005. 
ANEXO III - DADOS DOS PRODUTOS EMPRREAADOS NOS ENSANOS

Figura 125- Dados técnicos da lâmpada fluorescente tubular T5 FH 14/28W

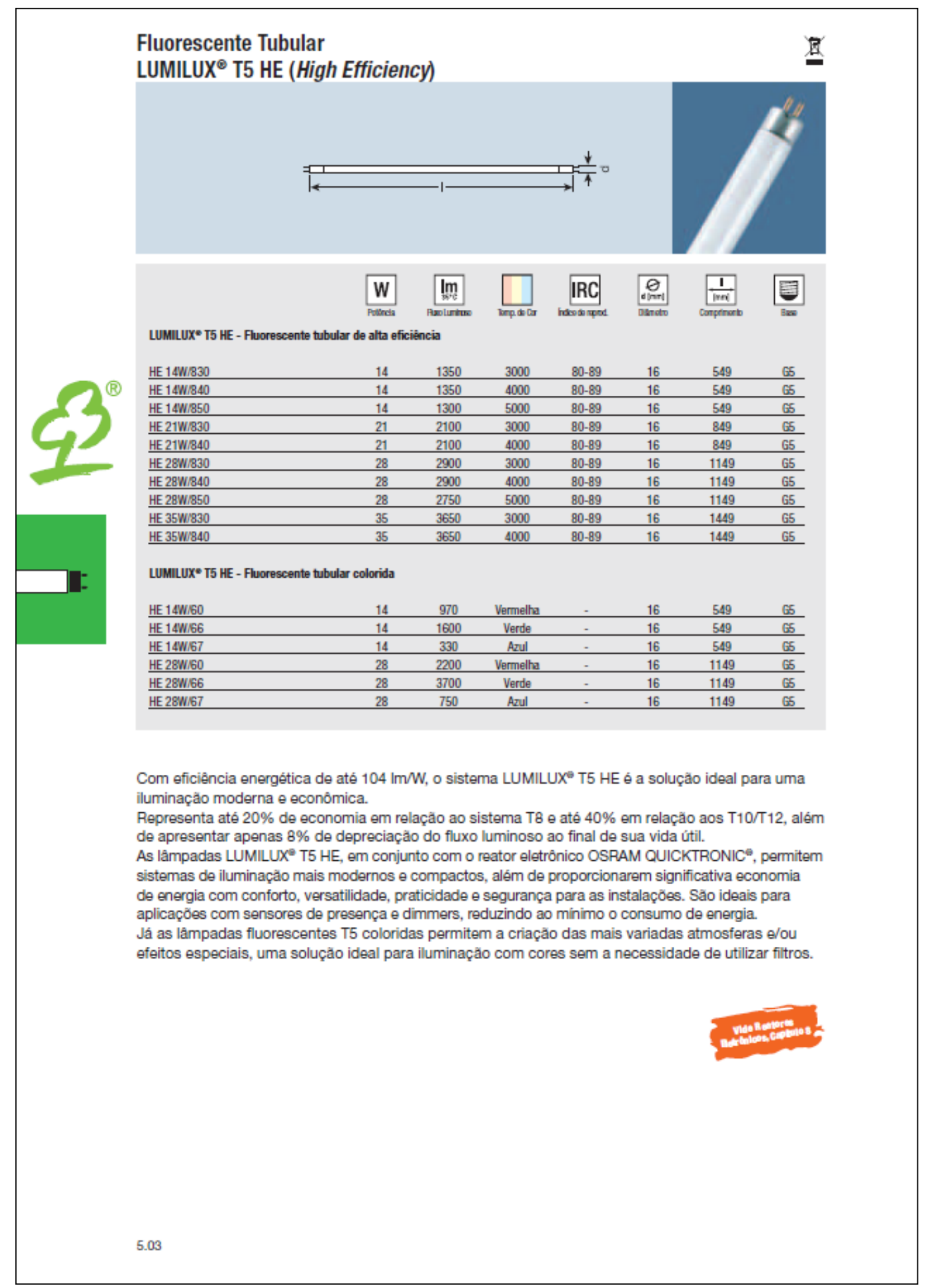

Fonte: OSRAM, 2011. 
Figura 126 - Dados técnicos do reator eletrônico QTP 5 2x14-35W/230-240V

\section{QUICKTRONIC ${ }^{\circledR}$ PROFESSIONAL T5 Reator para lâmpadas fluorescentes T5}

\section{QTP $51 \times 14-35$ QTP 5 2x14-35}

Informações

Técnicas

Edição: Mai. 2006

\section{Características:}

- Tecnologia Cut-off

- Acendimento da lâmpada otimizado com pré-aquecimento em menos de 1 segundo

- Apropriado para iluminação com alta quantidade de acendimentos

- Vida útil de 50.000 horas com $10 \%$ máximo de falhas com $\mathrm{t}_{\mathrm{c}}=75^{\circ} \mathrm{C}$

- Acendimento automático na troca da lâmpada

- Desligamento automático em caso de falha na lâmpada

- Apropriado para instalações de emergência de acordo com VDE 0108

- Apropriado para luminárias com classe de proteção I e II

\section{Dados Técnicos:}

\begin{tabular}{|c|c|c|}
\hline Referência: & QTP $51 \times 14-35$ & QTP $52 \times 14-35$ \\
\hline Lâmpadas: & $\begin{array}{c}1 \times \mathrm{FH} 14 \mathrm{~W} / \mathrm{FH} 21 \mathrm{~W} / \mathrm{FH} \\
28 \mathrm{~W} / \mathrm{FH} 35 \mathrm{~W}\end{array}$ & $\begin{array}{c}2 \times \mathrm{FH} 14 \mathrm{~W} / \mathrm{FH} 21 \mathrm{~W} / \mathrm{FH} \\
28 \mathrm{~W} / \mathrm{FH} 35 \mathrm{~W}\end{array}$ \\
\hline Potência da lâmpada [W]: & $14 / 21 / 28 / 35$ & $2 \times 14 / 21 / 28 / 35$ \\
\hline Potência do sistema [W]: & $16 / 24 / / 32 / 39$ & $31 / 46 / 62 / 78$ \\
\hline Corrente de entrada $[\mathrm{A}]$ : & $0,08 / 0,11 / 0,14 / 0,18$ & $0,15 / 0,21 / 0,28 / 0,35$ \\
\hline Fluxo luminoso à $25^{\circ} \mathrm{C}[\mathrm{lm}]$ : & $1200 / 1900 / 2600 / 3300$ & $2 \times 1200 / 1900 / 2600 / 3300$ \\
\hline Fluxo luminoso à $35^{\circ} \mathrm{C}[\mathrm{lm}]$ : & $1350 / 2100 / 2900 / 3650$ & $2 \times 1350 / 2100 / 2900 / 3650$ \\
\hline Tempo de pré-aquecimento: & \multicolumn{2}{|c|}{$<1 \mathrm{seg}$} \\
\hline Tensão de alimentação: & \multicolumn{2}{|c|}{$230 \mathrm{~V}-240 \mathrm{~V}$} \\
\hline Faixa de tensão $(\mathrm{AC})$ : & \multicolumn{2}{|c|}{$198 \mathrm{~V}-254 \mathrm{~V}$} \\
\hline Faixa de tensão (DC): & \multicolumn{2}{|c|}{$154 \mathrm{~V}-276 \mathrm{~V}$; para ignição da lâmpada $198 \mathrm{~V}$} \\
\hline Freqüência: & \multicolumn{2}{|c|}{$50 / 60 \mathrm{~Hz}$} \\
\hline Freqüência de operação: & \multicolumn{2}{|c|}{$40-50 \mathrm{kHz}$} \\
\hline Corrente máxima na partida: & $I_{p}=24 \mathrm{~A} ; T_{H}=230 \mu \mathrm{S}$ & $I_{P}=40 \mathrm{~A} ; T_{H}=200 \mu \mathrm{S}$ \\
\hline Fator de potência: & $\lambda=0,93 \mathrm{c} / 0,95 / 0,96 / 0,97$ & $\lambda=0,98 / 0,98 / 0,98 / 0,99$ \\
\hline Faixa de temperatura $t_{\mathrm{a}}$ : & \multicolumn{2}{|c|}{$-20^{\circ} \mathrm{Ca}+50^{\circ} \mathrm{C}$} \\
\hline Temperatura do invólucro $t_{c}$ : & \multicolumn{2}{|c|}{ máx. $+75^{\circ} \mathrm{C}$} \\
\hline Dimensões $(\mathrm{x} \times \mathrm{w} \times \mathrm{h})$ : & $360 \times 30 \times 21 \mathrm{~mm}$ & $423 \times 30 \times 21 \mathrm{~mm}$ \\
\hline $\begin{array}{l}\text { Distância entre furos de } \\
\text { fixação: }\end{array}$ & $350 \mathrm{~mm}$ & $415 \mathrm{~mm}$ \\
\hline Peso: & $240 \mathrm{~g}$ & $300 \mathrm{~g}$ \\
\hline Segurança: & \multicolumn{2}{|c|}{ acc. to EM 61347-2-3 / IEC 61347-2-3 } \\
\hline Interferência: & \multicolumn{2}{|c|}{ acc. to EN 55015 / CISPR 15} \\
\hline Distorção harmonica: & \multicolumn{2}{|c|}{ acc. to EN $61000-3-2$ / IEC $61000-3-2$} \\
\hline Imunidade: & \multicolumn{2}{|c|}{ acc. to EN 61547 / IEC 61547} \\
\hline Aprovaçöes: & \multicolumn{2}{|c|}{ 占 } \\
\hline
\end{tabular}


Figura 127- Dados técnicos do reator eletrônico QTP 5 2x14-35W/230-240V

QUICKTRONIC ${ }^{\circledR}$ PROFESSIONAL T5 Reator para lâmpadas fluorescentes T5 Informações Técnicas Edição: Mai. 2006

QTP 5 1x14-35 QTP 5 2x14-35

Produtos:

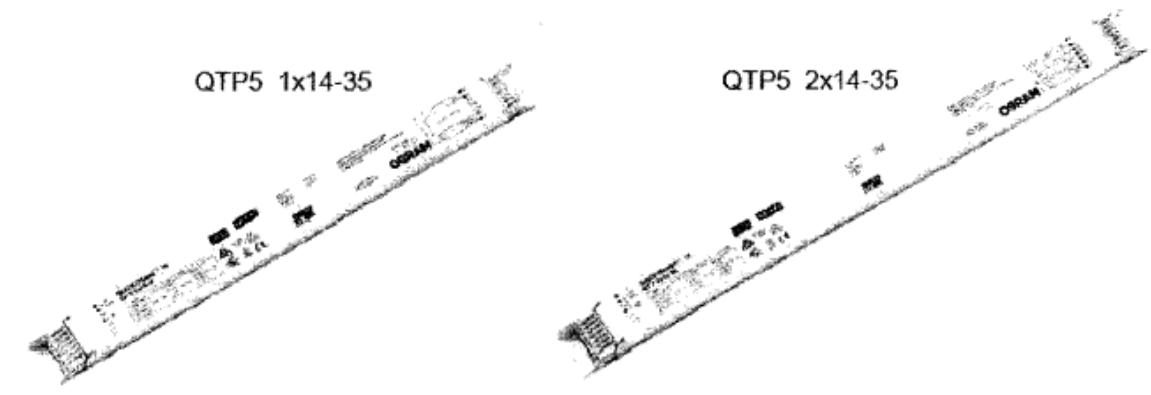

Esquema de ligação:

QTP 5 1x14-35

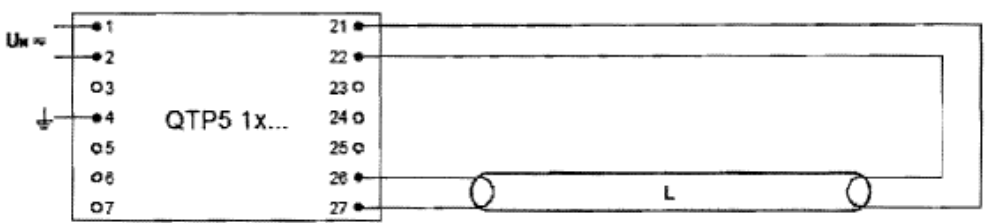

Máximo comprimento dos cabos entre o reator e a lâmpada: 2,0 m (PIN 21; 22); 1,0 M (PIN 26, 27) QTP 5 2x14-35

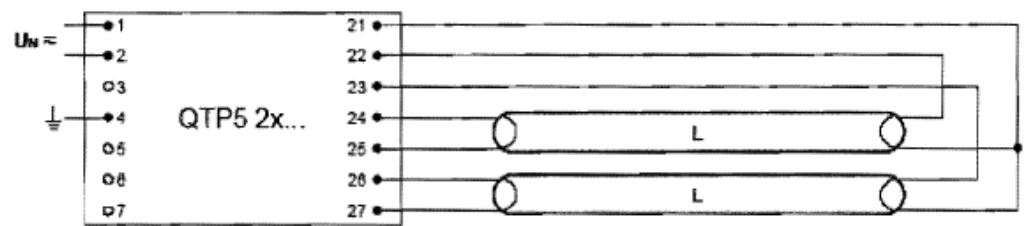

Máximo comprimento dos cabos entre o reator e a lâmpada: 2,0 m (PIN 21; 22); 1,0 M (PIN 23, 24, 25, 26, 27) 
Figura 128- Dados técnicos do alumínio ALCOA.

\section{jeuropeanmillproducts}

\section{bright products technical data}

\begin{tabular}{|l|c|c|c|c|c|}
\hline & $\begin{array}{c}\text { Cosmetic } \\
\text { Packaging }\end{array}$ & Decoration & $\begin{array}{c}\text { Continuous } \\
\text { Anodizing }\end{array}$ & $\begin{array}{c}\text { External } \\
\text { Lighting }\end{array}$ & $\begin{array}{c}\text { Internal } \\
\text { Lighting }\end{array}$ \\
\hline Alloys & $\begin{array}{c}\text { EN AW-1050 } \\
\text { EN AW-3003 } \\
\text { EN AW-5005 } \\
\text { EN AW-8011 } \\
\text { EN AW-5657 }\end{array}$ & $\begin{array}{c}\text { EN AW-1050 } \\
\text { EN AW-1080 } \\
1085 A^{11} \\
\text { EN AW-1085 } \\
\text { EN AW-1090 }\end{array}$ & $\begin{array}{c}\text { EN AW-5005 } \\
\text { EN AW-1080 } \\
1085 A^{11} \\
\text { EN AW-1085 } \\
\text { EN AW-1090 }\end{array}$ & $\begin{array}{c}\text { EN AW-1050 } \\
\text { EN AW-1070 } \\
\text { EN AW-1080 } \\
1085 A^{\prime \prime}\end{array}$ & 1200/1199 clad" \\
\hline $\begin{array}{c}\text { Mill finish } \\
\text { Brillo Industrial } \\
\text { Commercial Bright } \\
\text { Fini Brillant }\end{array}$ & $\begin{array}{c}\text { Mill Finish } \\
\text { Brillo Industrial } \\
\text { Brillo } \\
\text { Fini Brillant } \\
\text { Grand Brillant } \\
\text { Brillo }\end{array}$ & $\begin{array}{c}\text { Finil Brillant } \\
\text { Grand Brillant } \\
\text { Semi Specular }\end{array}$ & Mill Finish & $\begin{array}{c}\text { Fini Brillant } \\
\text { Grand Brillant }\end{array}$ \\
\hline Tempers & H2X & H18, H26 & H16, H18, H26 & 0 & H18, 0 \\
\hline Thickness (mm) & $0.3-1.0$ & $0.3-1.0$ & $0.2-1.0$ & $0.8-2.0$ & $0.5-1.2$ \\
\hline Width (mm) & $24-1500$ & $46-1250$ & $810-1250$ & $250-1500$ & $46-1250$ \\
\hline Product form & Strip & Strip, Sheet & Strip & Strip & Strip, Sheet \\
\hline
\end{tabular}

Other material specifications and dimensions may be available, subject to enquiry.

1) $1085 \mathrm{~A}$ is a high purity alloy designed specifically for bright applications.

2) Core material EN AW-1200 clad with $15 \%$ or $20 \%$ AA 1199.

\begin{tabular}{|c|c|c|c|c|c|c|}
\hline $\begin{array}{c}\text { Surface } \\
\text { finish }\end{array}$ & $\begin{array}{c}\text { Brillo } \\
\text { Industrial }\end{array}$ & Brillo & $\begin{array}{c}\text { Commercial } \\
\text { Bright }\end{array}$ & $\begin{array}{c}\text { Fini } \\
\text { Brillant }\end{array}$ & $\begin{array}{c}\text { Grand } \\
\text { Brillant }\end{array}$ & $\begin{array}{c}\text { Semi } \\
\text { Specular }\end{array}$ \\
\hline $\begin{array}{c}\text { Specular } \\
\text { Gloss }^{3}\end{array}$ & $45 \%$ & $70 \%$ & $65 \%$ & $75 \%$ & $75 \%$ & $50 \%$ \\
\hline
\end{tabular}

3) According to DIN 67530, ASTM D523 and ISO 2813 standards, measured at $20^{\circ}$ with reflectometer in rolling direction. These values show guaranteed minimum gloss on raw samples in hard temper. They can vary strongly dependent on alloy, temper and dimensions.

\section{SURFACE QUALITY}

All our surface finishes - from Mill Finish to Grand Brillant - are appreciated for their uniform appearance. Brillo, Fini Brillant and Grand Brillant surfaces reach specular gloss values from $72 \%$ up to $85 \%^{3}$. All respond excellently to further surface treatments such as brightening, anodizing or lacquering.

\section{FORMABILITY}

In addition to surface finish and reflectivity, many applications such as cosmetic packaging and reflectors demand material with optimised mechanical properties. Alcoa provides aluminium alloys with metallurgical structure and mechanical properties to meet the demands of our customers forming processes, which include drawing, deep drawing and spinning.

\section{CERTIFICATION}

- ISO $9001-$ Quality Standard

- ISO 14001 -Environmental Standard

Our products comply with FDA and European directives regarding the use of aluminium in contact with food, cosmetics and pharmaceuticals.

\section{PACKAGING AND SURFACE PROTECTION}

Vertical or horizontal packing, pallet or case. Products can be delivered with surface protection such as paper interleave or plastic film. 
Figura: 129 - Dados técnicos do alumínio 100/030/B - 100/040/B, ALMECO.

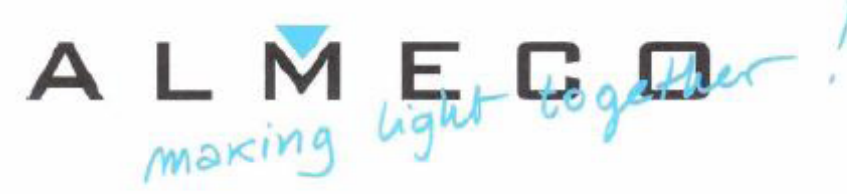

Description: Electro-chemically brightened and anodised mirror finish aluminium produced in our ISO 9002 certificated plant under controlled conditions respecting the European standards quoted below

Dimension: $1.250 \mathrm{~mm} \times 2.500 \mathrm{~mm}$

INSPECTION REPORT ART. $100040 \mathrm{~B}$

\begin{tabular}{|l|l|c|c|}
\hline Test & Result & Requirement & Norms \\
\hline
\end{tabular}

Material:

\begin{tabular}{|l|l|l|l|}
\hline Composition & Al $99.85 \%$ & 299.85 & EN 573/3 \\
\hline
\end{tabular}

Mechanical properties:

\begin{tabular}{|l|l|c|c|}
\hline Tensile stress & $181 \mathrm{~N} / \mathrm{mm}^{2}$ & $\geq 125$ & EN $485 / 2$ \\
\hline Yield stress & $167 \mathrm{~N} / \mathrm{mm}^{2}$ & $\geq 105$ & EN $485 / 2$ \\
\hline Elongation & $3.5 \%$ & $\geq 2$ & EN $485 / 2$ \\
\hline
\end{tabular}

Photometrics properties:

\begin{tabular}{|l|l|c|c|}
\hline Reflectance long & 82 (Refl. Dr. Lange; Head 60; REFO 3 D) & $82 \pm 1$ & DIN 67530 \\
\hline Reflectance trans & 80 (Refl. Dr. Lange; Head 60; REFO 3 D) & $80 \pm 1$ & DIN 67530 \\
\hline Iridescence & L & L & Internal \\
\hline
\end{tabular}

NOTES:

Iridescence Internal classification

$\mathrm{N}=$ Normal
$L=$ Low
$V=$ Very low
$G=$ No iridescence

April 2011

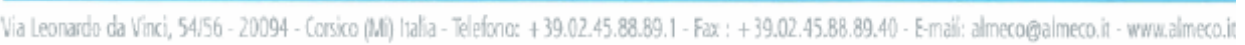

Fonte: ALMECO, 2011. 
Figura: 130 - Dados técnicos do alumínio VEGA 95100, ALMECO.

\section{VEGA 95100}

Vega 95100 is the mirror finish product in the Vega range. Its enhanced optical characteristics make it the ideal material for a wide range of reflector applications requiring very high efficiency.

\section{Optical properties}

\begin{tabular}{|l|l|l|}
\hline Total reflectance & ASTM E 1651 TR2 Reflectometer & $\begin{array}{l}>95 \% \\
>95 \%\end{array}$ \\
\hline DIN 5036 Integrating sphere & $<10 \%$ \\
\hline Specular reflectance & DIN 5036 Integrating sphere & $88 \%$ \\
& ISO 7668 60 degree, Longitudinal & $88 \%$ \\
\hline Iridescence & & Absent \\
\hline
\end{tabular}

\section{Base material}

\begin{tabular}{|l|l|l|}
\hline Pre-anodized aluminium & 1085 alloy, purity $99.85 \%$ & Temper $-\mathrm{H} 18$ \\
\hline Mechanical Properties & Tensile strength typical & $160-200 \mathrm{~Pa}$ \\
& $0,2 \%$ Proof Stress typical & $150-190 \mathrm{MPa}$ \\
& Elongation min. & $2 \%$ \\
\hline
\end{tabular}

\section{Coating system characteristics}

Anodized base coat, covered by a high reflectance, $99.99 \%$ pure aluminium reflectance layer, and an outer dual layer vacuum deposited oxide system, tuned for maximum reflection enhancement.

\section{Coating performance}

\begin{tabular}{|l|l|}
\hline Bending & $\begin{array}{l}\text { No film de-lamination on forming to a bend radius of } \\
\text { 1t in long or transverse directions. }\end{array}$ \\
\hline Adhesion & $\begin{array}{l}\text { Cross hatch tape pull-off test - no detachment of } \\
\text { coating. }\end{array}$ \\
\hline
\end{tabular}

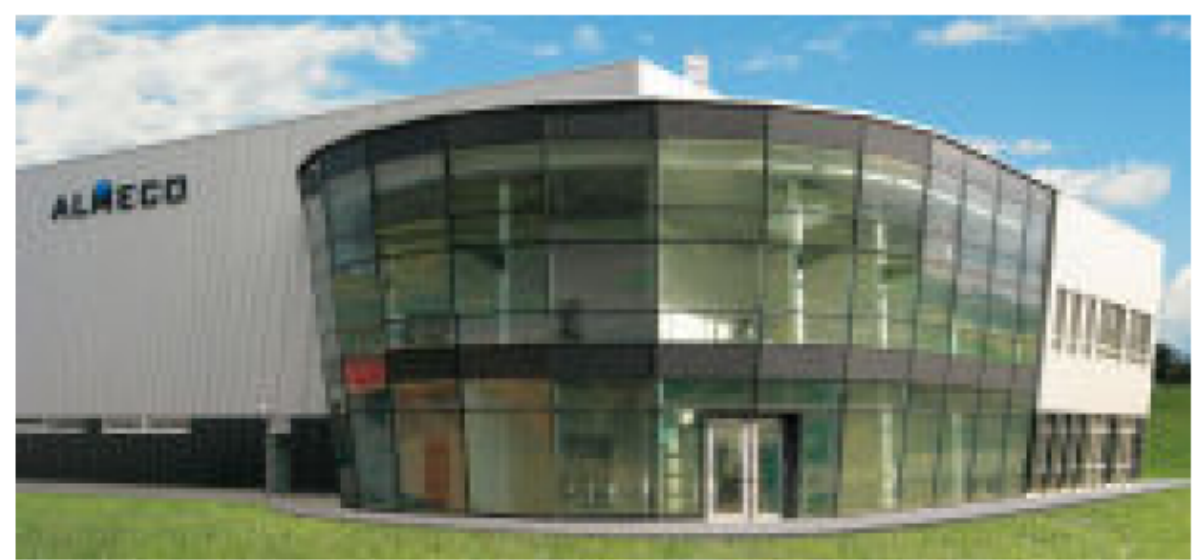

Vega plant in Bernburg, Germany

Fonte: ALMECO, 2011. 